\title{
Fuel Summary for Peach Bottom Unit 1 High- Temperature Gas-Cooled Reactor Cores 1 and 2
}

\author{
K. I. Kingrey
}

April 2003

Idaho National Engineering and Environmental Laboratory Bechtel BWXT Idaho, LLC 


\title{
Fuel Summary for Peach Bottom Unit 1 High-Temperature Gas-Cooled Reactor Cores 1 and 2
}

\author{
K. I. Kingrey
}

Published April 2003

Idaho National Engineering and Environmental Laboratory Idaho Falls, Idaho 83415

\author{
Prepared for the \\ U.S. Department of Energy \\ Assistant Secretary for Environmental Management \\ Under DOE Idaho Operations Office \\ Contract DE-AC07-99ID13727
}




\section{DISCLAIMER}

This document has been prepared using the best available sources of information. Every reasonable attempt has been made to ensure that the data have been correctly extracted and summarized from source documents. However, this document may contain incomplete and inaccurate information for reasons that include, without limitation:

1. The original source documents contained errors

2. Source documents could not be located that contained appropriate data and information

3. Source documents contained conflicting information, and engineering judgment has been used to select the data and information presented in this document

4. Additional data may exist but are yet to be located.

Document users need to ensure that this information is adequate for the intended use. Bechtel BWXT Idaho, LLC makes no representation or warranty, expressed or implied, as to the completeness, accuracy, or usability of the data or information contained in this report. 


\section{ABSTRACT}

This fuel summary report contains background and summary information for the Peach Bottom Unit 1, High-Temperature, Gas-Cooled Reactor Cores 1 and 2. This report contains detailed information about the fuel in the two cores, the Peach Bottom Unit 1 operating history, nuclear parameters, physical and chemical characteristics, and shipping and storage canister related data. The data in this document have been compiled from a large number of sources and are not qualified beyond the qualification of the source documents. This report is intended to provide an overview of the existing data pertaining to spent fuel management and point to pertinent reference source documents. For design applications, the original source documentation must be used. While all referenced sources are available as records or controlled documents at the Idaho National Engineering and Environmental Laboratory (INEEL), some of the sources were marked as informal or draft reports. This is noted where applicable.

In some instances, source documents are not consistent. Where they are known, this document identifies those instances and provides clarification where possible. However, as stated above, this document has not been independently qualified and such clarifications are only included for information purposes.

Some of the information in this summary is available in multiple source documents. An effort has been made to clearly identify at least one record document as the source for the information included in this report. 


\section{ACKNOWLEDGMENT}

The INEEL/EXT-2000-00389, "Data Package for Peach Bottom High-Temperature Gas-Cooled Reactor Cores 1 and 2," compiled by R. K. McCardell in May 2000, was the starting point for this fuel summary. The references cited in the McCardell document provided the bulk of the information in this fuel summary. The description of how the core positions were numbered is based directly on information from the McCardell document. This information was not found in any other reference documents. Compilation of the detailed Core 2 fuel element table also benefited from work done for the related table in the McCardell report.

Thanks are due to Billie Reagan for her expert help in locating and providing copies of drawings and other documents. Vickie Boyer assisted by providing valuable information regarding the status of fuel storage at the Idaho Nuclear Technology and Engineering Center.

Nancy Smith at the Idaho National Engineering and Environmental Laboratory researched a number of the complex issues regarding Peach Bottom fuel that were not well documented previously. She accumulated documents including copies of drawings, correspondence, transcripts of personal interviews, and excerpts from operator logs. These documents and Nancy Smith's assistance were most helpful in compiling this fuel summary. 


\section{CONTENTS}

DISCLAIMER iii

ABSTRACT iv

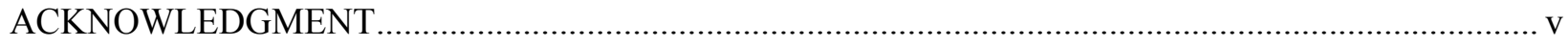

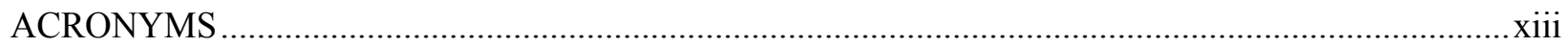

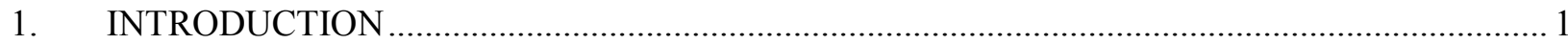

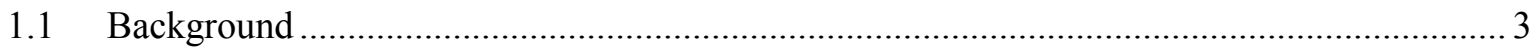

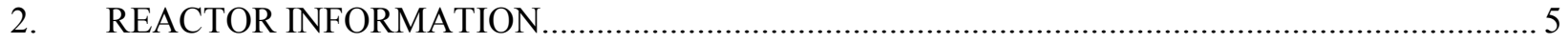

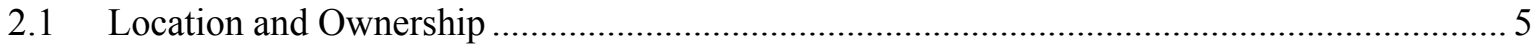

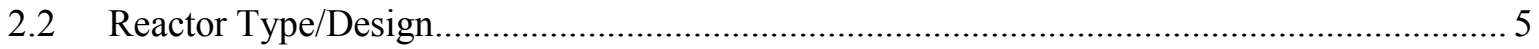

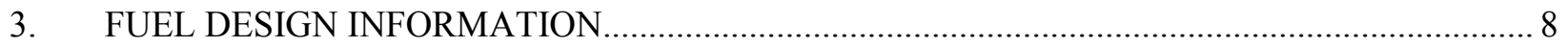

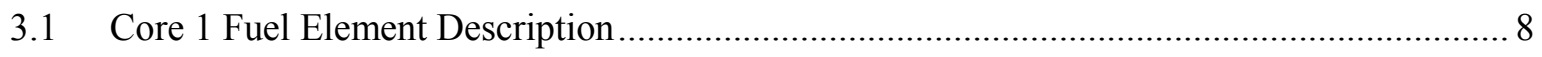

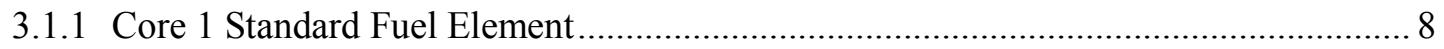

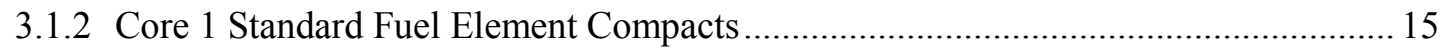

3.1.3 Core 1 Standard Fuel Element Fuel Particles .............................................................. 16

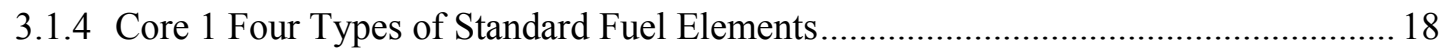

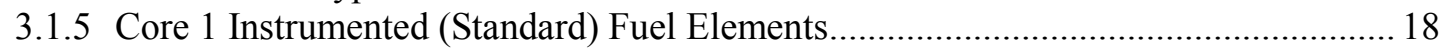

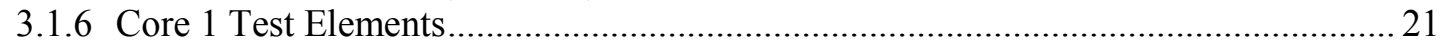

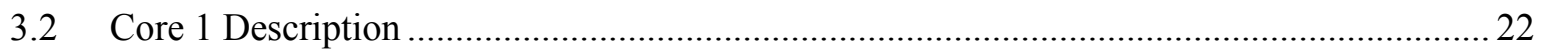

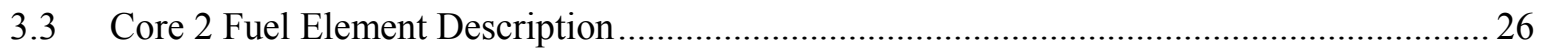

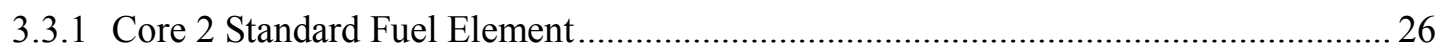

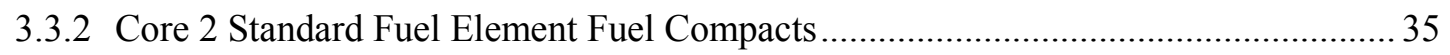

3.3.3 Core 2 Standard Fuel Element Fuel Particles ........................................................ 35

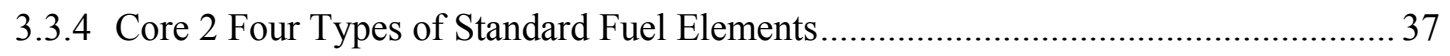

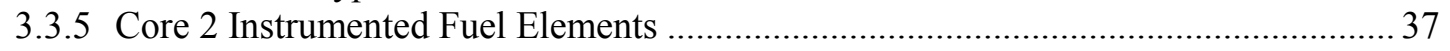

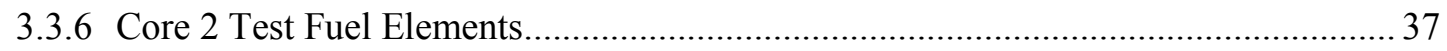

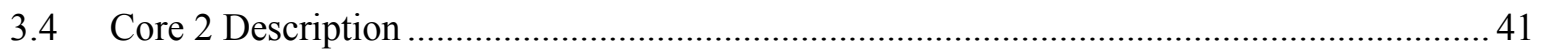

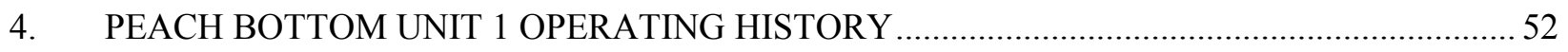

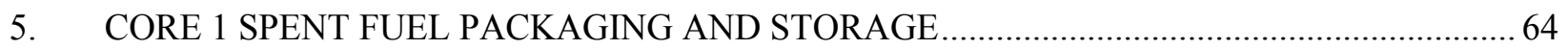

6. DISCUSSION OF CORE 1 TABLE OF SPENT FUEL ELEMENTS .......................................... 90

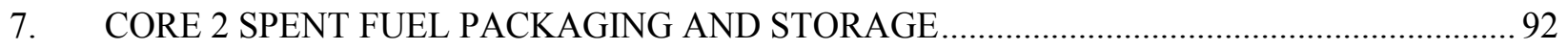


8. DISCUSSION OF Core 2 TABLE OF SPENT FUEL ELEMENTS.

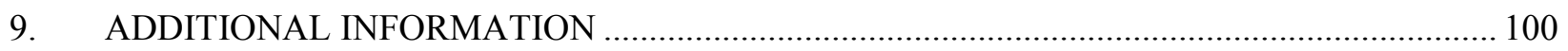

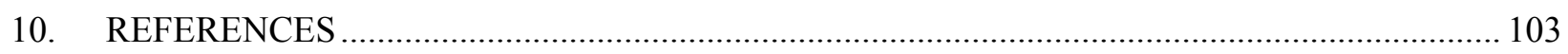

Appendix A-Detailed Information for Peach Bottom, Unit 1 HTGR Core 1 Fuel Elements................. A-1

Appendix B-Detailed Information for Peach Bottom, Unit 1 HTGR Core 2 Fuel Elements................ B-1

\section{FIGURES}

1. Cutaway view of Peach Bottom, Unit 1, HTGR Core and Pressure Vessel.................................. 6

2. Major components of the Peach Bottom Atomic Power Station .................................................. 7

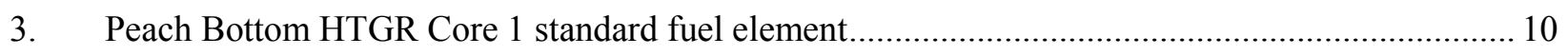

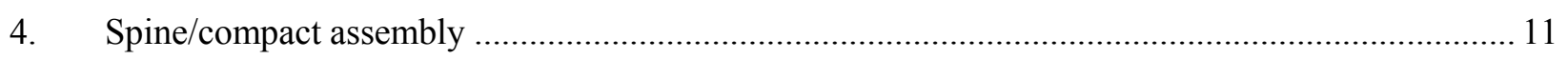

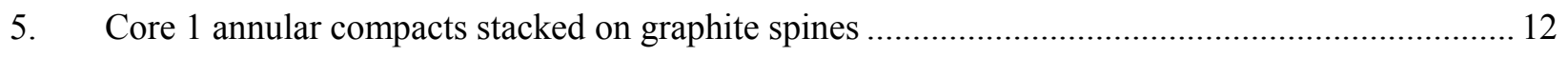

6. Peach Bottom HTGR Core 1 instrumented fuel assembly...................................................... 20

7. Plan view of Peach Bottom core at initial criticality showing the fuel element identification

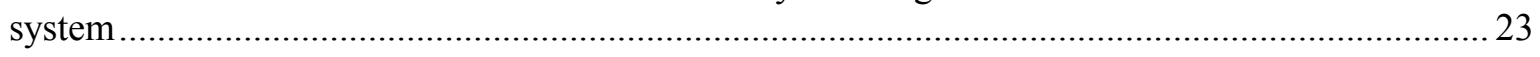

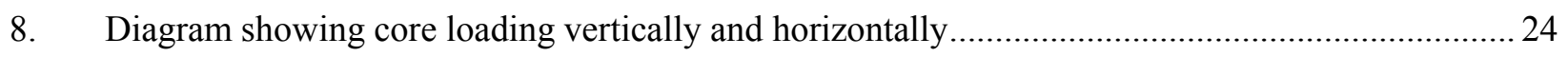

9. Map of core showing initial zones for the four different types of standard fuel elements ..............25

10. Peach Bottom HTGR Core 2 standard fuel element................................................................. 27

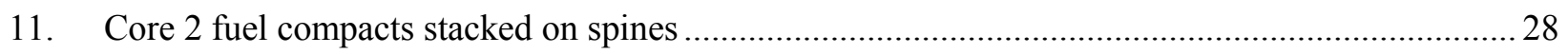

12. Element E06-01, an instrumented Core 2 standard fuel element …...........................................2 29

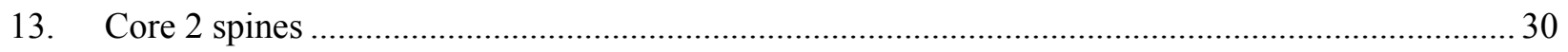

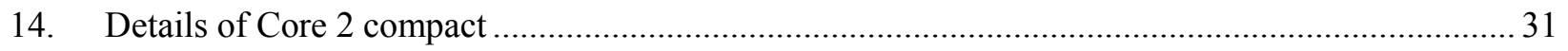

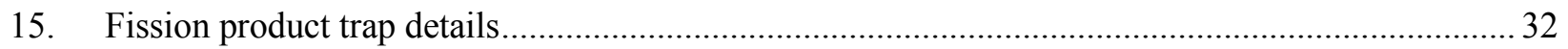

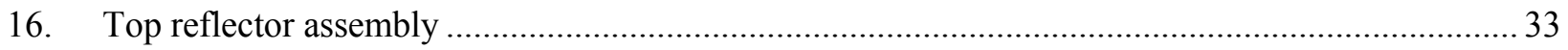

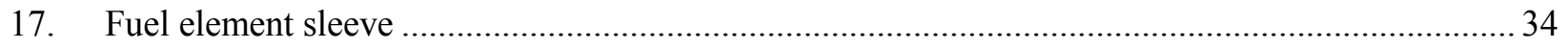

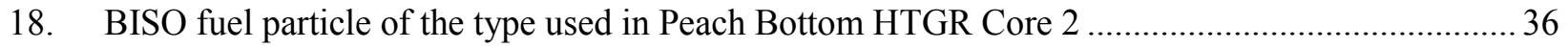

19. Core 2 instrumented fuel elements as stored in INEEL IFSF …................................................ 38

20. Two configuration types of test fuel elements used in Peach Bottom............................................. 39 
21. Axial view of six-body FTEs, RTEs, and FBTEs

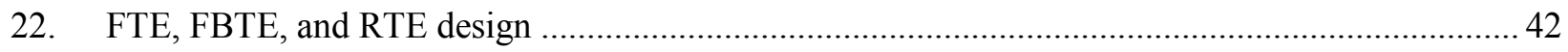

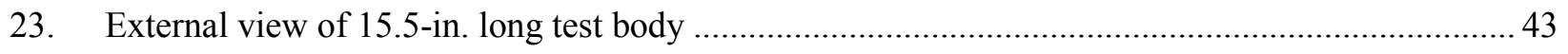

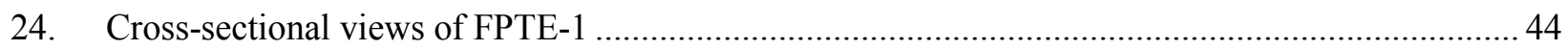

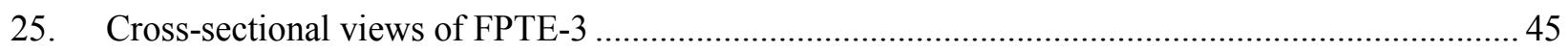

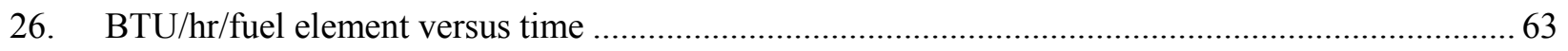

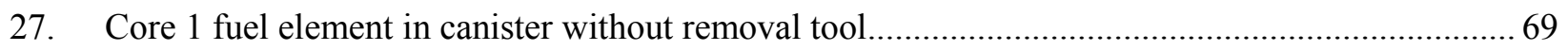

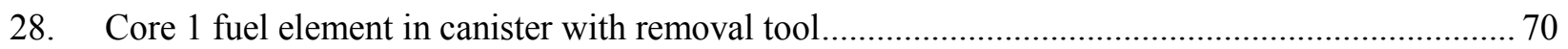

29. Core 1 fuel element with removal tool in storage canister inside of a salvage canister .................. 71

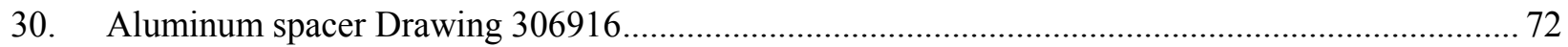

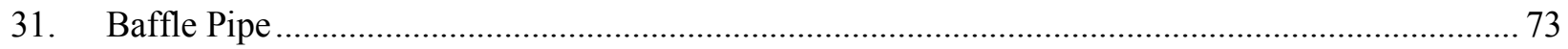

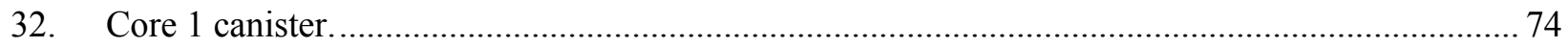

33. Fuel element removal tool, Drawing 800-156-15005, the Type 2 tool ...................................... 75

34. Fuel element removal tool, Drawing 800-156-18000, dimensions not compatible with Core 1

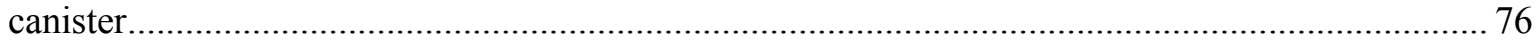

35. Fuel element removal tool, Drawing 800-156-15000 - Probably the Type 1 tool......................... 77

36. Stainless steel storage basket used for Peach Bottom fuel in CPP-749 ....................................... 83

37. CPP-749 storage facility (plan view) showing locations of Peach Bottom Core 1

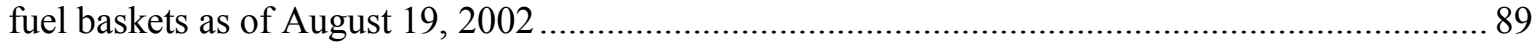

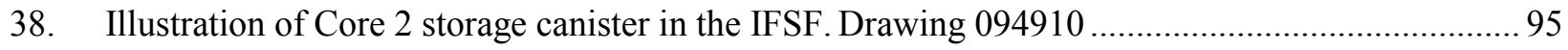

39. IFSF plot plan as of December 12, 2002. This plot plan is an information only copy ................... 96

40. Canister planned for Peach Bottom Fuel currently in the FECF, CAN-GSF-276-X,

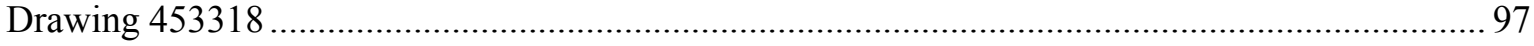

41. Lid to canister planned for Peach Bottom Fuel currently in the FECF, Drawing 453321 ..............98 


\section{TABLES}

1. Significant milestone dates for the Peach Bottom high-temperature gas-cooled reactor .................. 3

2. Basic components and materials of standard fuel elements .................................................... 14

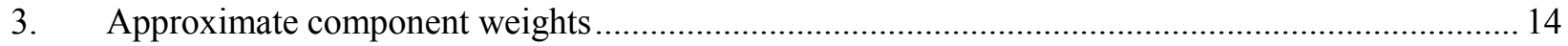

4. Core 1 fuel element composite chemical (impurities) ppm ....................................................... 15

5. Core 1 fuel compact initial heavy metal loadings ................................................................. 15

6. Summary of Core 1 fuel particle failures - from element C05-05 ............................................ 18

7. Core 1 fuel element types and number of fuel elements in 804-element Core 1 ......................... 19

8. Core 1 standard fuel element initial heavy metal loadings in grams ........................................... 19

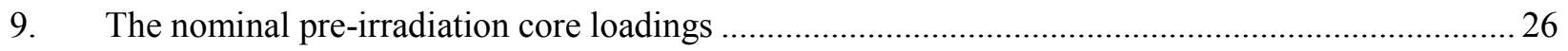

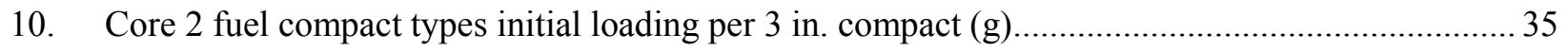

11. Core 2 standard fuel element initial heavy metal loadings in grams .......................................... 37

12. Peach Bottom Unit 1 test element fissionable loadings............................................................ 46

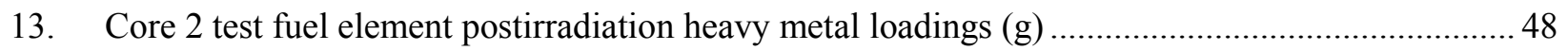

14. Test Element $\mathrm{OPyC}$ densities as a function of fast fluence and temperature ................................. 49

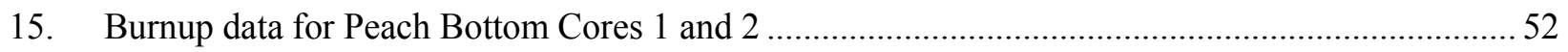

16. Isotopic activity concentrations in curies for a single Peach Bottom Unit 1 Core 1 Type II fuel

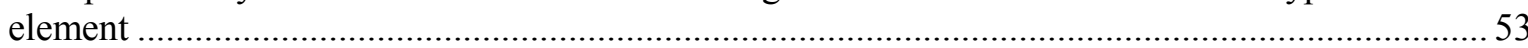

17. Isotopic activity concentrations in curies for a single Peach Bottom Unit 1 Core 2 Type II fuel

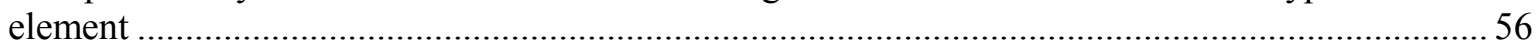

18. Heat generation calculated for a Type II element in Core 1 and in Core 2 for July 2005 ...............59

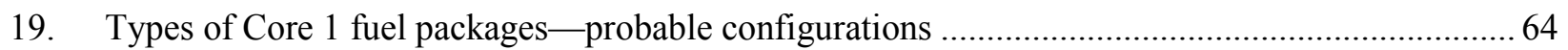

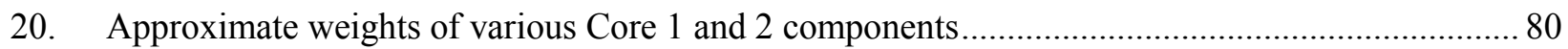

21. Changes in mass, volume, and density of uncoated (Th, $\mathrm{U}) \mathrm{C}_{2}$ particles hydrolyzed under various conditions

22. Reported offgas compositions from $\mathrm{UC}_{2}$ and $\mathrm{ThC}_{2}$ reactions with water in mol\%.................... 85

23. Summary of Core 1 postirradiation uranium loadings per element by fuel package type............... 87

24. Summary of total postirradiation fuel loadings for 813 Core 1 fuel elements .............................. 88 
25. Postirradiation heavy metal loadings for Core 2 (standard) fuel elements.................................. 93

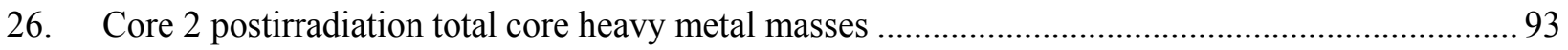




\section{ACRONYMS}

AEC

BISO

BOL

EDF

EFPD

EOL

FBTE

FECF

FPTE

FSV

GA

HTGR

IFSF

INEEL

INTEC

NSS

OPyC

ORNL

PB

PTE

RTE

SAR

SNF

TRISO
Atomic Energy Commission

buffer isotropic

beginning of life

engineering design file

equivalent full power days

end-of-life

fuel bed test element

Fuel Element Cutting Facility

fuel pin test element

Fort St. Vrain

General Atomic (Company)

high-temperature gas-cooled reactor

Irradiated Fuel Storage Facility

Idaho National Engineering and Environmental Laboratory (previously known as the National Reactor Testing Station and as the Idaho National Engineering Laboratory [INEL])

Idaho Nuclear Technology and Engineering Center (previously known as the Idaho Chemical Processing Plant)

nuclear steam supply system

outer pyrolytic carbon

Oak Ridge National Laboratory

Peach Bottom

proof test element

recycle test element

safety analysis report

spent nuclear fuel

Tricoating isotropic 
UKAEA United Kingdom Atomic Energy Authority

USAEC United States Atomic Energy Commission 


\section{Fuel Summary for Peach Bottom Unit 1 High- Temperature Gas-Cooled Reactor Cores 1 and 2 \\ 1. INTRODUCTION}

This fuel summary is intended to be an aid in locating and understanding detailed information about the fuel from the two Peach Bottom Unit 1 cores (Core 1 and Core 2). Fuels from Peach Bottom reactors other than Unit 1 are not discussed in this summary.

Some original source documents for this report have not been located. Some parts of the original documents are illegible. Some original documents have internal inconsistencies, and some documents are inconsistent with each other. During the research for this report, an attempt was made to analyze the information available and resolve as many of the inconsistencies as possible. Many of the original source documents contain information repeated from earlier documents. This summary distills redundant information where possible and provides at least one source document reference for the presented information.

Most of the sources are available as Peach Bottom spent nuclear fuel (SNF) records at the Idaho National Engineering and Environmental Laboratory (INEEL). As of March 2003, there are two systems of record storage where images of most documents can be located. Both are available through the INEEL Electronic Document Management System via an Electronic Records Vault Search, specifying INEEL, Nuclear Material, Fuel Information. One system, maintained by Nuclear Fuel Operations personnel at the Idaho Nuclear Technology and Engineering Center (INTEC), is under "Fuel Descriptive Data." The other system, maintained by the INEEL SNF Program, is under "SNF Docs." Where possible, the identification number for the INEEL SNF Program record is referenced. These numbers usually start with "PB," but occasionally start with "FSV." If the document is only in the INTEC system, that number is referenced. The INTEC system numbers usually start with "Peach Bottom." The original document identifier is also given in the reference section. Access to some of the document images requires password authorization. Hard copy files are also maintained for both systems.

Photographs in many of the source documents are too dark to be useful, although the hard copies are sometimes clearer than the images. Many drawings and some tables are partly illegible. In the past, attempts have been made to locate additional documents. Correspondence from General Atomics (GA) Company personnel ${ }^{1}$ indicates that documents, which might have been stored at the GA Hot Cell where some of the fuel was examined, were probably destroyed when the facility was demolished if not before.

While researching the fuel summary information, errors in early source documents were identified, some of which had been propagated in subsequent documents. A brief summary follows of potentially significant information that was found to be incorrect in some documents. Additional details are given elsewhere in this document, as appropriate.

- $\quad$ The liner in the Core 1 canisters is 1020 mild steel—not stainless steel.

- $\quad$ The documents supplied with Core 1 spent fuel when it was shipped from Peach Bottom, included many incorrect drawings. Errors in the master list of fuel sent with Core 1 are detailed in Section 5.

- Weights given for the Core 1 fuel often did not consider salvage canisters or other special package types.

- $\quad$ Drawings depicting different package types were incorrect. 
- $\quad$ The fuel particle kernels are mixed thorium-uranium oxide. The fertile and fissile materials are not in separate particles.

- The percentage of failed particles in the Core 1 fuel is often given as up to $84 \%$. That is from examination of only four compacts from one element withdrawn early from the core. Other data show $100 \%$ failed particles.

- $\quad$ Organic and metallic components including rubber, silver, silver paint, furfuryl alcohol/maleis anhydride binders, and polyethylene are listed in some documents but not others. The references to silver are probably incorrect, and the anhydride binders may have been destroyed during fuel manufacturing. The rubber is only mentioned for the packaging for one Core 1 element. Other organic materials generally pertain only to test elements.

- $\quad$ The Core 1 loading was changed from the original configuration given in several documents. Twenty-four Type II elements were replaced with Type III elements. In Core 2, eight Type IIIs were then replaced with Type IIs. The power distribution in Core 2 was not symmetrical as a result of this last change.

- The canisters were not "back-filled with helium," but were sealed in a helium atmosphere. The canisters were not designed with a means to backfill them.

- Weights of boron and rhodium in the elements were incorrect in one of the GA source documents.

Information in this document that may not have been available to users before includes:

- $\quad$ The research to determine the correct information provided enough additional information to be able to determine the fuel type, package type, and core location for most of the spent fuel. This information has been added to the appendix tables. The electronic versions of the tables, when completed, can be sorted by core position, serial number, can or cap number, basket position (for Core 1), storage location, package type (for Core 1), shipment number, fuel type and content of uranium or plutonium isotopes or by thorium content. These tables are expected to be extremely useful for management and transfer of these fuels.

- $\quad$ Description of the Magnaform sealing process was included. Description of the Buna-N-4387 compound used for the O-rings was included.

- The Peach Bottom Operating History provided detail on broken elements and canisters that had to be resealed after they were stored underwater. This information is included in the document and in the appendix tables. All other available information about the history of individual elements was added to the appendix tables.

- $\quad$ Pertinent information from operator logs and fuel transfer documents was added, including information about possibly broken Core 2 elements in the IFSF canisters. Information that the salvage canister for element 263 in the PWR1 storage vault in CPP-749 was bent and mushroomed at the bottom when it was dropped in 1988 was also added.

- Information on the weights of Core 1 fuel storage baskets is included.

- $\quad$ The document was organized more efficiently with less repeated information.

- $\quad$ Tables on source terms were added. 
- $\quad$ Many drawings were added and existing drawings were upgraded.

\subsection{Background}

Unit 1 at the Peach Bottom Atomic Power Station was a 40-MW(e) high-temperature gas-cooled reactor (HTGR) demonstration plant, which was owned and operated by the Philadelphia Electric Company. The plant is located about 80 miles southwest of Philadelphia on the west shore of the Susquehanna River. This was the first installation of an HTGR in the United States. ${ }^{2,3}$

The plant was operated between March 3, 1966, and October 31, 1974, at which time the plant was shut down for decommissioning. Over 1.2 million MW(e)-hr were produced for the Philadelphia Electric Company grid over a lifetime of 1,349 equivalent full power days (EFPD) with a gross plant capacity factor of $74 \%$ (see References 2 and 3). Two cores of graphite fuel were irradiated in the reactor (see Reference 2).

The significant milestone dates for the Peach Bottom Unit 1 HTGR are listed in Table 1.

Table 1. Significant milestone dates for the Peach Bottom high-temperature gas-cooled reactor. ${ }^{\text {a }}$

\begin{tabular}{|c|c|c|}
\hline Month & Year & Milestone Completed \\
\hline August & 1959 & $\begin{array}{l}\text { Contracts signed by the USAEC, }{ }^{b} \text { Philadelphia Electronic Company, General } \\
\text { Atomics }\end{array}$ \\
\hline February & 1962 & Construction permit issued \\
\hline January & 1964 & Vessel shipment to site \\
\hline January & 1965 & Fuel shipment to site \\
\hline January & 1966 & License for $1-\mathrm{MW}(\mathrm{t})$ operation received \\
\hline February & 1966 & Fuel loading began \\
\hline March & 1966 & Initial criticality \\
\hline April & 1966 & Core 1 loading completed \\
\hline May & 1966 & Low-power testing completed \\
\hline January & 1967 & Full-power license issued \\
\hline May & 1967 & Full power reached \\
\hline June & 1967 & Start of commercial operation for Core 1 \\
\hline February & 1968 & Core 1168 Equivalent Full Power Day (EFPD) Shutdown \\
\hline November & 1968 & Core 1300 EFPD Shutdown \\
\hline October & 1969 & Shut down for refueling \\
\hline November & 1969 & Core 1452 EFPD end-of-life \\
\hline July & 1970 & Start of commercial operation for Core 2 \\
\hline May & 1971 & Core 2252 EFPD Shutdown \\
\hline February & 1972 & Core 2385 EFPD Shutdown \\
\hline October & 1973 & Core 2701 EFPD Shutdown \\
\hline October & 1974 & Core 2 end-of-life, plant shutdown for decommissioning \\
\hline November & 1974 & Core 2897 EFPD Shutdown \\
\hline
\end{tabular}


Core 1 operated only about half of its design life due to failure of 90 fuel elements caused by rupture of the fuel particle coatings. Some of the elements that failed early in the run were replaced. Core 2 used an improved particle design and was able to operate its full design life. Core 1 included two test elements for part of the run. The second test element was left in the core for part of the Core 2 run. Core 2 had over 30 additional test elements.

Most of the Core 1 fuel was shipped to the INEEL in the early 1970s and stored in underground dry wells at INTEC. Most of the Core 2 fuel was shipped to the INEEL in the late 1970s and stored in the Irradiated Fuel Storage Facility (IFSF) at INTEC. Many of the test elements were sent elsewhere for examination and are not stored at the INEEL. In the future, some Peach Bottom elements are still expected to be received at the INEEL. 


\section{REACTOR INFORMATION}

\subsection{Location and Ownership}

Location and ownership of the Peach Bottom Unit 1 reactor are discussed under Section 1.1.

\subsection{Reactor Type/Design}

Unit 1 at the Peach Bottom Atomic Power Station was a 40-MW(e) HTGR demonstration plant.

The nuclear steam supply system (NSS) was designed, developed, and supplied by GA. The engineer-constructor was the Bechtel Corporation. Financing was provided by HTGR Development Associates, a nonprofit organization composed of 53 investor-owned utilities throughout the United States and by the United States Atomic Energy Commission (USAEC) as part of the Power Reactor Demonstration Program (see References 2 and 3).

The heart of the Peach Bottom NSS was a helium-cooled, graphite-moderated, $115 \mathrm{MW}(\mathrm{t})$ reactor operating on a thorium-uranium fuel cycle. The NSS generated more than 3.72 million MW(t)-hr and 1.38 million gross MW(e)-hr from an average gross plant thermal efficiency of $37.2 \%$. It produced $538^{\circ} \mathrm{C}$ superheated steam at a pressure of $1,450 \mathrm{lb} /$ in. $^{2}$ (see Reference 2) with an overall lifetime availability of $88 \%$. A cutaway view of the Peach Bottom HTGR core and pressure vessel is shown in Figure 1 (see References 2 and 3).

Radioactivity in the main coolant system was controlled by drawing a purge stream of helium through the fuel elements to the external fission product trapping system. The system consisted of a series of low-temperature delay beds and fission product traps to remove and permit decay of fission products. A dehydrator, an oxidizer, and a liquid-nitrogen-cooled charcoal trap removed moisture, chemical impurities, and the Kr-85 from the main coolant system (see References 2 and 3).

Upon exit from the upper core plenum, the coolant flow was split between two parallel loops as shown in Figure 2. Centrifugal compressors forced the outlet gas at approximately $700^{\circ} \mathrm{C}$ through the steam generators, where it was cooled to about $330^{\circ} \mathrm{C}$ before it entered the circulators for return to the core. The steam generators were forced-recirculation drum-type boilers having pendant u-tube superheater, evaporator, and economizer sections. The superheater tubes were made of Incoloy 800, and the other sections were carbon steel. The primary pressure boundary was also carbon steel. The hot gas was contained inside concentric ducting or shrouds insulated with metallic thermal barrier to keep the steel temperatures within acceptable limits (see References 2 and 3).

The plant was designed to produce $40 \mathrm{MW}(\mathrm{e})$ net maximum and could follow load automatically down to $30 \%$ at rates in excess of $3 \%$ per minute. Thermal efficiency at the design operating conditions was approximately 39\% (see References 2 and 3).

In addition to producing commercial power, Peach Bottom was a prototype nuclear power station. This situation required that power changes, including shutdowns, be performed to accommodate testing. Surveillance programs to monitor core component performance, fission product release and plateout, circulating activity, coolant chemistry, and other features of operation were continued throughout the reactor lifetime by GA and the Oak Ridge National Laboratory (ORNL) (see References 2 and 3).

Subsequent to reactor shutdown, the Peach Bottom End-of-Life (EOL) Program was initiated with the objective to validate HTGR design codes and predictions. There was also a complementary program of fuel element postirradiation examinations at ORNL (see Reference 3). 


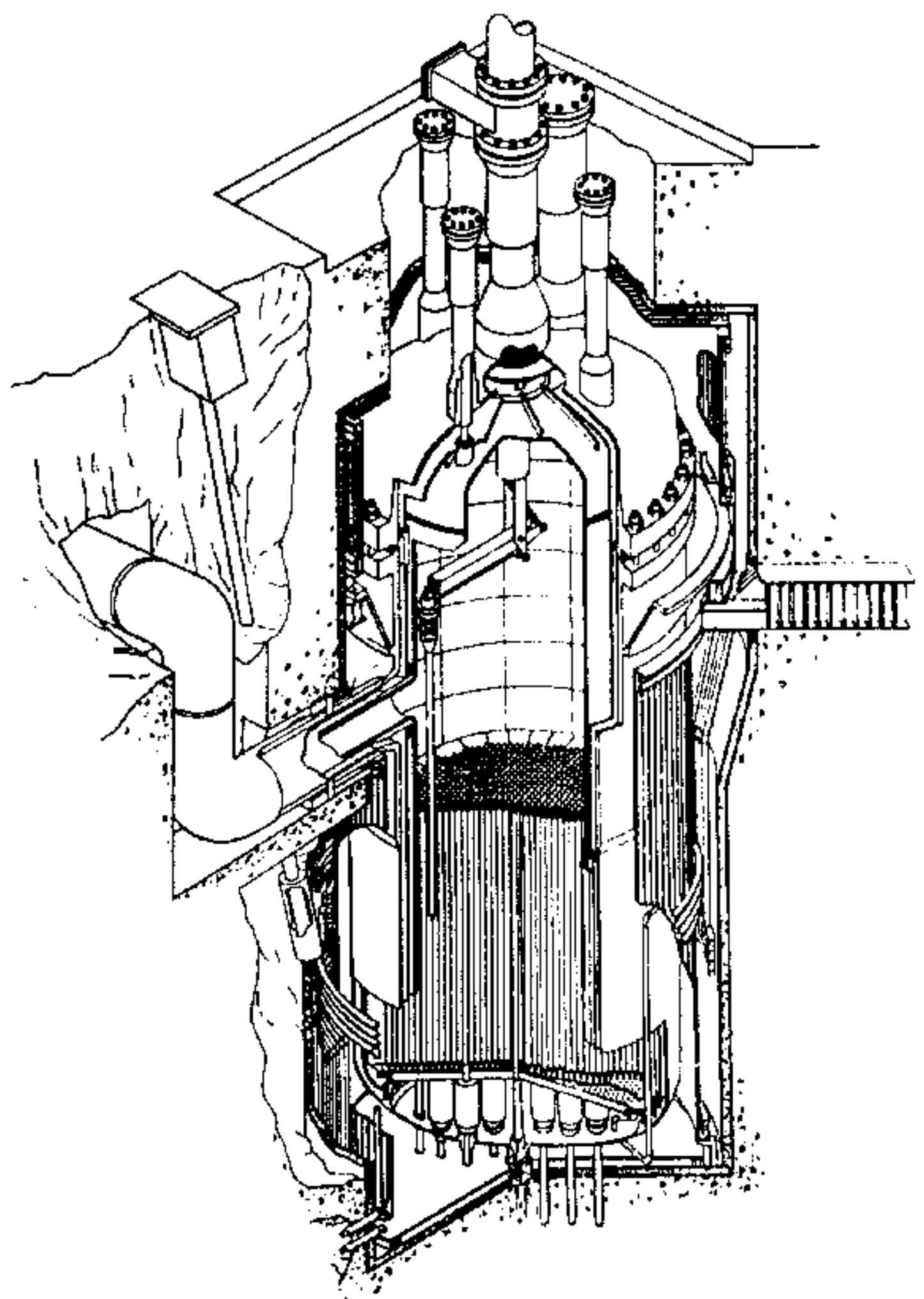

Figure 1. Cutaway view of Peach Bottom, Unit 1, HTGR Core and Pressure Vessel. (Reference 2 Figure 2-2 and Reference 3, Figure 2-2). 


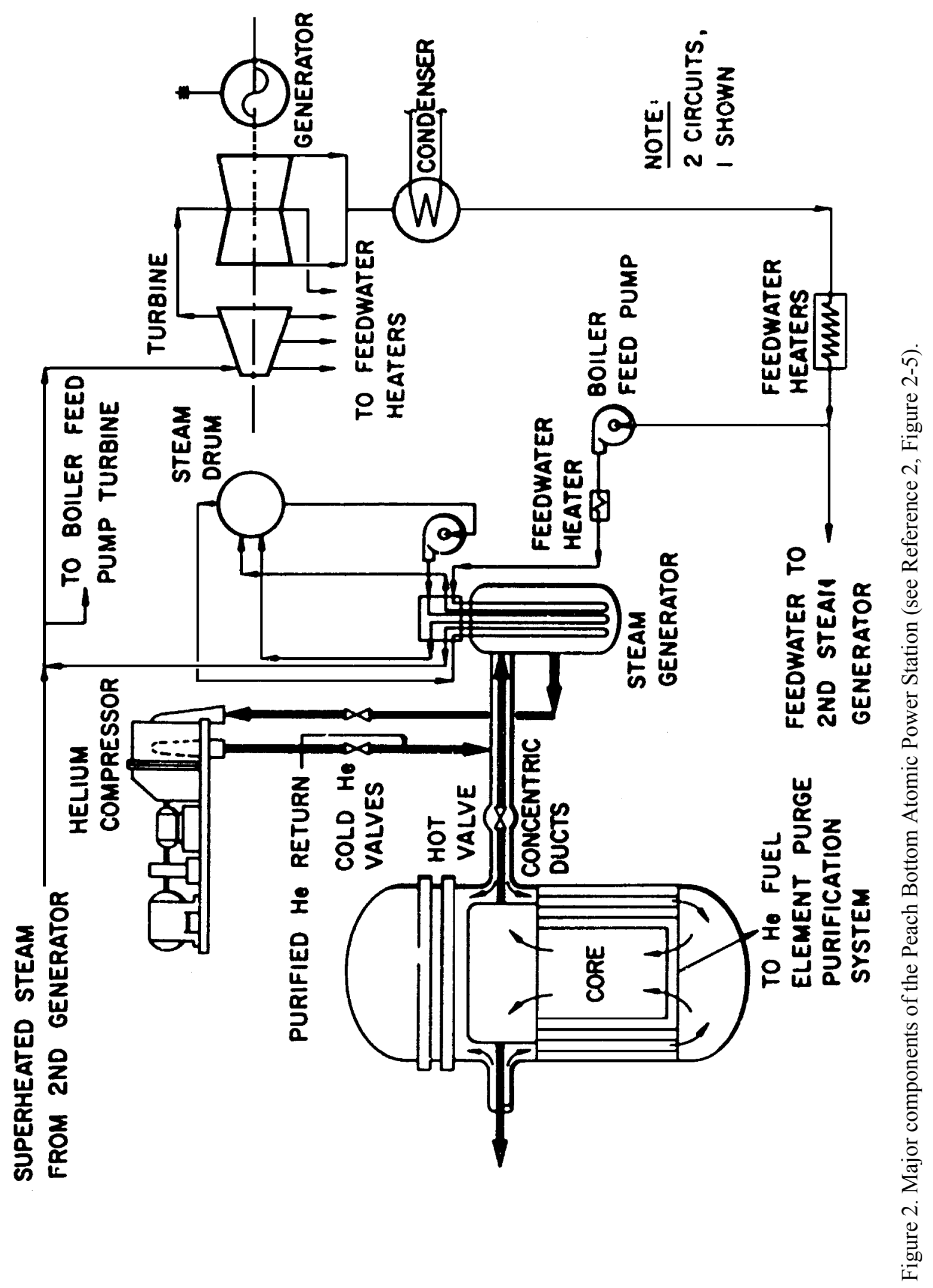




\section{FUEL DESIGN INFORMATION}

\subsection{Core 1 Fuel Element Description}

Three basic fuel element classes were irradiated in both cores:

1. Standard fuel elements of which there were four types

2. Instrumented standard fuel elements

3. Test elements.

\subsubsection{Core 1 Standard Fuel Element}

The Peach Bottom Atomic Power Station standard fuel element had the outward appearance of a graphite cylinder $3.5 \mathrm{in}$. in diameter and $12 \mathrm{ft}$. long. The core was designed to contain 804 fuel elements. The total number of fuel elements from the two cores exceeded 1,608 because of replacement fuel and test elements that were exchanged with other elements for part of the reactor operating time. In addition, the core contained 36 control rod guide tubes and 19 emergency shutdown rod guide tubes, which were all made of graphite and similar in shape to the fuel elements. The control rods and emergency shutdown rods were not sent to the INEEL. All standard fuel elements were of the same external geometry with a grappling knob at the top for handling. ${ }^{4}$

The information in the GA report (Reference 4) closely aligns with the type of information this fuel summary is intended to provide, so it is heavily referenced in this report. Reference 4 is stamped with a disclaimer regarding the accuracy of the report and with a notice stating the report contains information of a preliminary nature for internal use. Where errors have been identified in the GA report, they are discussed in this fuel summary. However, much of the information in the GA report was presented without identifying how it was derived. It was not possible to confirm the accuracy of many of the tables and of the data in the GA report. As with other information in this fuel summary, material drawn from Reference 4 should be considered unqualified.

The standard fuel element for Core 1, shown in Figure 3 (see Reference 4, Figure 1), was a solid semihomogeneous type in which graphite served as the moderator, reflector, cladding, fuel matrix, and structure. Each standard fuel element consisted of an upper reflector assembly, a fuel bearing middle section, a lower reflector, and an internal fission product trap. The fuel materials, part of the lower reflector, and the fission product trap were contained in a sleeve of low permeability graphite, joining the upper reflector on one end and a bottom connector fitting on the other (see Reference 4).

A stainless-steel screen installed at the bottom of each fission product trap retained any graphite granules that might have been released from the graphite body of the internal trap during HTGR operation. Within the sleeve, the mixture of fissile and fertile materials that make up the fuel are contained in annular compacts stacked on graphite spines, as shown in Figures 4 and 5 (see References 4 and 5).

Spacer rings machined onto the outside surface of the fuel elements at three axial locations served to maintain the pitch and prevent line contact along the length of the elements. ${ }^{6}$ As shown on the fuel element drawing (Figure 3), the spacer rings increase the diameter of the fuel element slightly.

In the core, each fuel element rested on its own stainless steel standoff support pin that was screwed into the core support plate. A female sealing surface within the bottom end of the fuel element 
slipped over a mating male portion of the standoff pin. This provided a gas seal for restricting fission product release as well as forming a rigid structural support to prevent lateral movement of the fuel elements (see References 4, 5, and 6).

The bottom connector and the sleeve are joined by a silicon braze. They formed the main barrier against fission product leakage from the element. The bottom connector and sleeve were made of graphite with a helium permeability of $3 \times 10^{-3} \mathrm{~cm}^{2} / \mathrm{sec}$ or less and an effective permeability to gaseous fission products of approximately $10^{-5} \mathrm{~cm}^{2} / \mathrm{sec}$ at reactor conditions (see References 4,5 , and 6).

The screen, internal trap assembly, lower reflector piece, and fuel compacts with spines are stacked in that order within the sleeve. The weight of these components is supported by the bottom connector. The lower reflector piece is a 3-in.-long graphite cylinder made of reactor-grade graphite. The annular fuel compacts fit over cylindrical graphite spine sections. These spine sections are approximately 30 in. long and about 1-3/4 in. in diameter. Three 30-in. spines would be used in the 90 -in. fuel bearing section of each element. There are two types of spines, one of solid graphite, and one of graphite with a 0.89-in. diameter axial hole to contain burnable poison compacts. The screen is made of $18-8$ stainless steel. The screen's purpose was to retain any charcoal granules that might be released from the graphite body of the internal trap (see References 4, 5, and 6).

In discussing the regions that correspond to 30 uniform 3-in. long compacts that would be on the three sections of a 90 -in. total spine (with 10 fuel compacts on each 30 -in. section), Peach Bottom-CSE-0002, ${ }^{7}$ states, "Occasionally, a shorter length was used to compensate for tolerance buildup in the total stack height." This might indicate that some standard elements have only 29 fuel compacts, or it might simply mean that the total height of the 30-compact stack was sometimes less than 90 in., or possibly a compact less than 3 in. long could have been used at the top of the stack. No other documents were located that indicate there might be less than 30 compacts in an element.

Section 1.2 of ORNL-5126 ${ }^{8}$, regarding element E06-01, states that portions of the drawings supplied by GA were redrawn. These drawings are clearer than most of the original drawings that have been located and are included in Section 3.3, Figures 12 through 17 under Core 2 information. E06-01 was an instrumented Core 2 element, so these drawings show thermocouples not present on a standard fuel element. There are also slight dimensional differences between these drawings and Core 1 drawings, even for components that are the same design. For instance, the diameter of the Core 1 spine is given in Reference 9 as 1.73 in. and is described in Reference 5 as having contracted (as expected) after 168 EFPD from 1.733 to 1.720 in., whereas the Core 2 solid spine diameter in the ORNL-5126 drawing is shown as 1.665 in.

The internal fission product trap is a graphite cylinder that is $2.75 \mathrm{in}$. in diameter by $12 \mathrm{in.}$ long. Each cylinder is machined with 16 slots, each 0.13 in. wide by $0.81 \mathrm{in}$. deep to hold a reagent that captured the gaseous fission products. The reagent is activated carbon made from coconut shells (see Reference 6).

FSV-0449 a states, "The fission product trap also includes graphite granules with a silver coating to getter the cesium and iodine fission products." No other mention of the silver coating was located, however. The draft plan did not give a reference for this specific information, but did state that some of the information was obtained from discussions with persons associated with or having knowledge of storage facilities, operation, or the history of the Fort St. Vrain (FSV) and Peach Bottom fuels.

a. S. C. Marschman et al., Pacific Northwest Laboratory, Characterization Plan for Fort St. Vrain and Peach Bottom Fuels, Draft, FSV-0449, September 1993. 


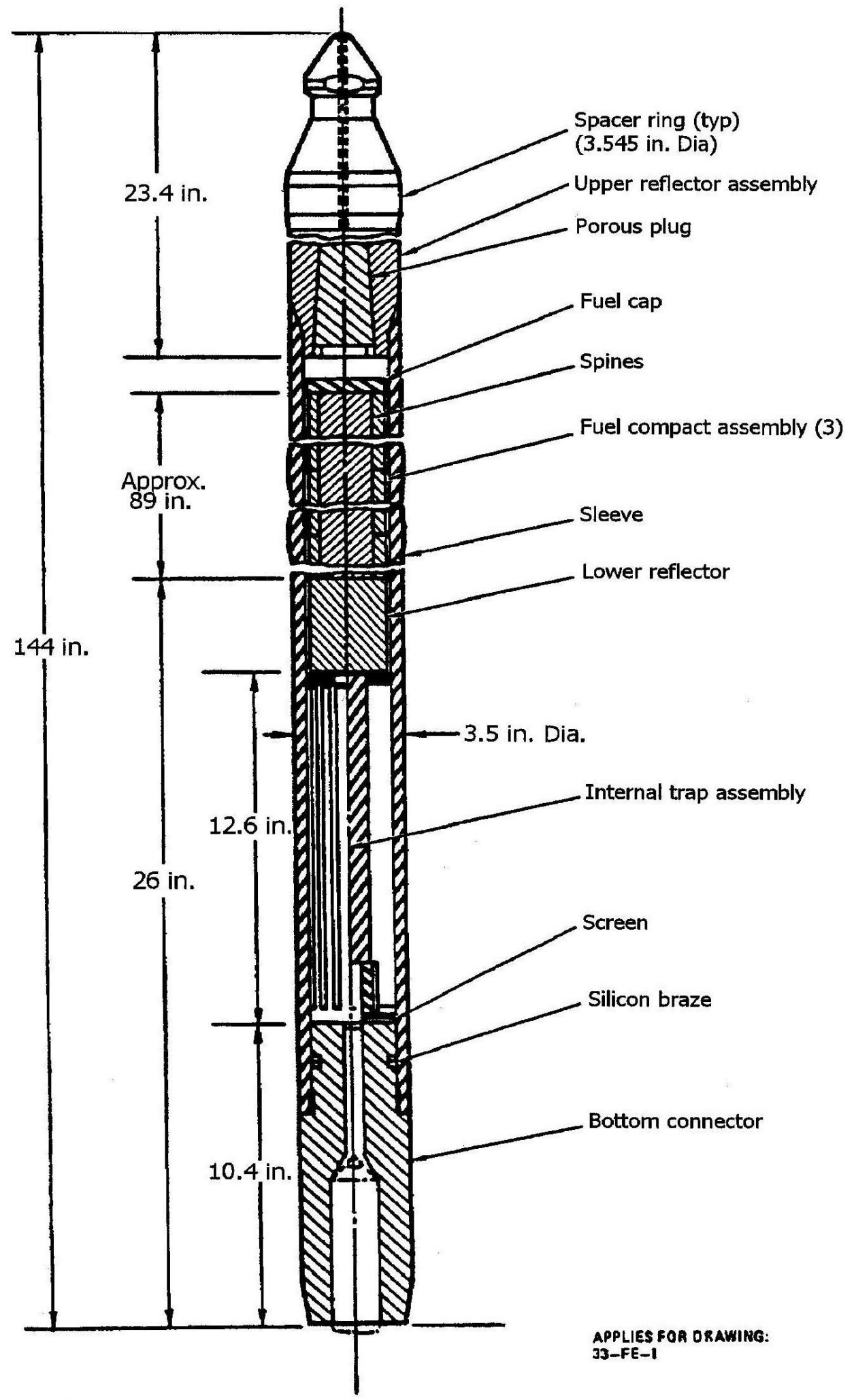

Figure 3. Peach Bottom HTGR Core 1 standard fuel element. (Reference 4, Figure 3-1). (Note: only one of the three spacer rings is shown [as being typical] in this drawing.) 


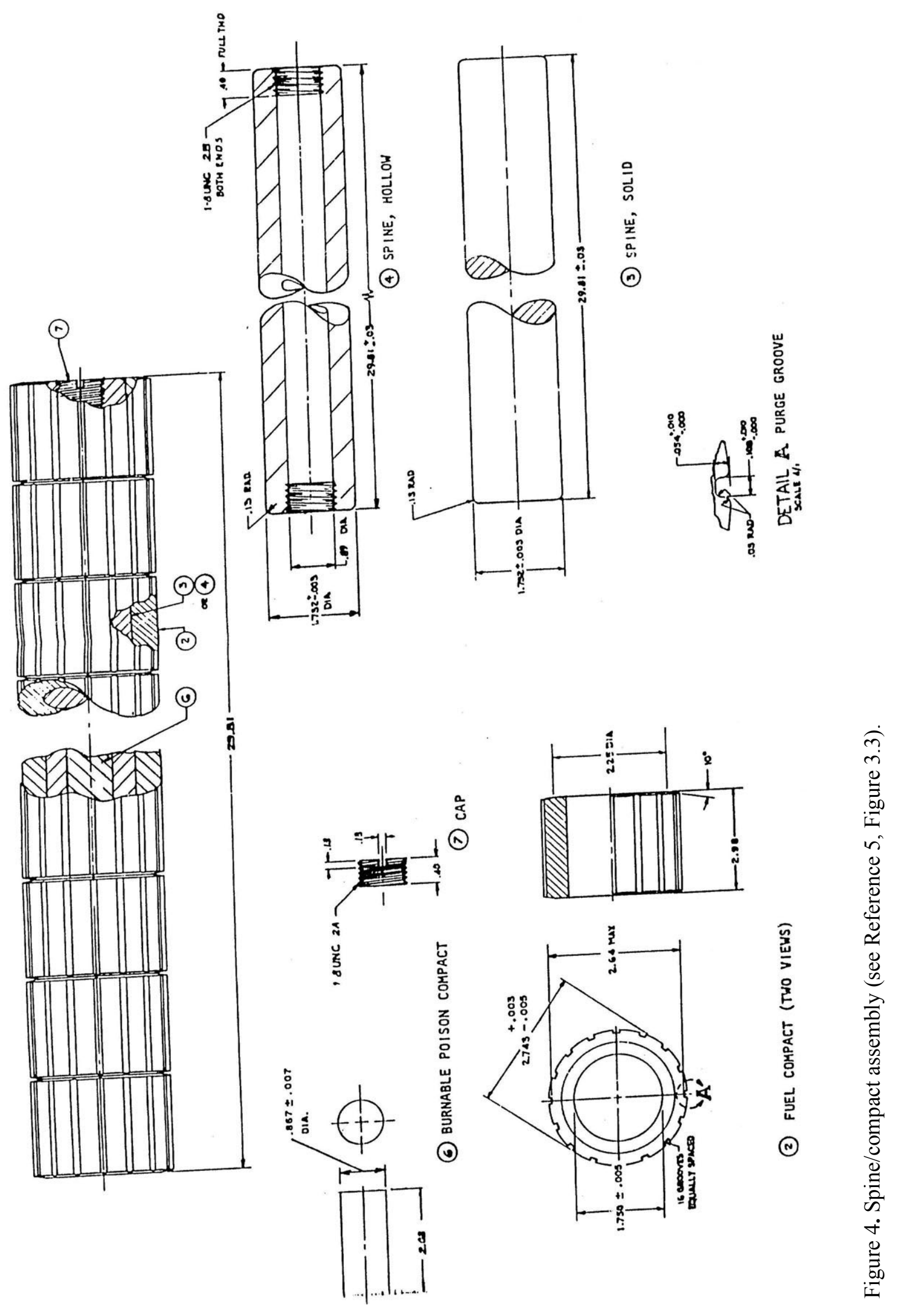




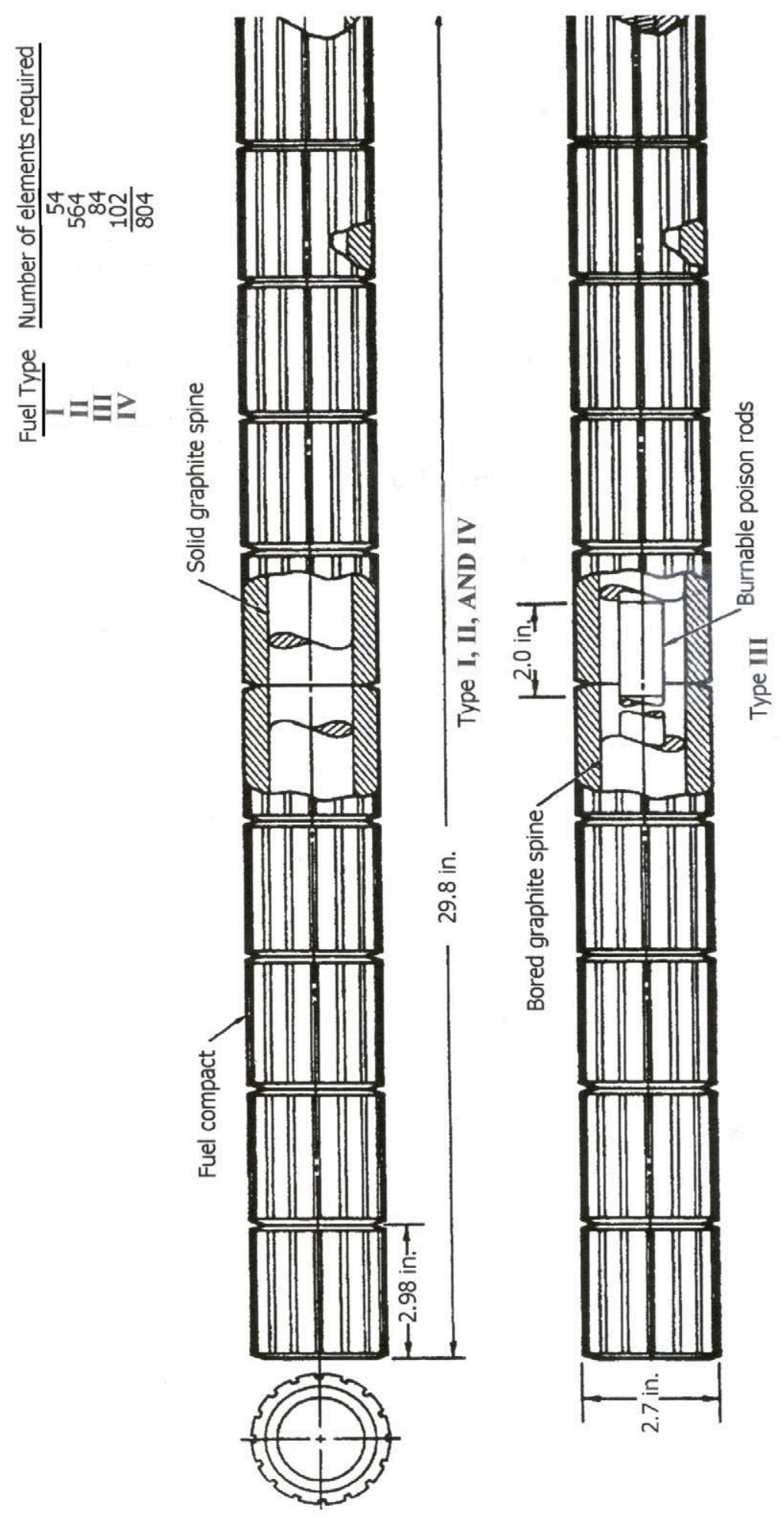

Figure 5. Core 1 annular compacts stacked on graphite spines. (Reference 4, Figure 3-2). 
The diametric clearance between the fuel compacts and the sleeve was $0.009+0.007$ or -0.005 in., cold, at the time of manufacture. The nominal clearance hot was $0.011 \mathrm{in}$. The fuel compact has a slightly smaller thermal expansion coefficient than the sleeve in the radial direction (see Reference 5).

The upper reflector assembly is a graphite piece that was threaded and cemented into the sleeve of the fuel element. The cement was a carbonaceous material that was furnace cured. The joint between the sleeve and the upper reflector did not need to be of a low permeability, because negligible fission product concentrations would exist at that location. For that reason, the upper reflector was not fabricated of low permeability graphite. The upper end of this reflector piece was machined for engagement with the fuel handling machines. A 1/4-in. diameter hole down the centerline of the reflector served as an inlet channel for purge gas. A porous plug cemented and retained within the upper reflector provided a controlled pressure drop for inflowing purge gas (see Reference 5).

Each fuel element had a serial number and a loading mark engraved on the surface. The loading mark indicated the type of fuel element loading. Elements that were instrumented had an additional marking (see Reference 5).

Reference 10 notes, "None of the silver paint appeared visible on the type number engraved on the upper reflector of B13-05 and B13-07... The best estimate of the number of fuel elements within the core having a visually detectable amount of silver paint still present is approximately $25 \%$." No other mention of silver paint was located.

A list from Reference 5 of the basic components and materials in a standard fuel element is shown in Table 2.

Table 3 gives approximate component weights from Reference 4 . Table 4 was adapted from information in Reference 4 and gives Core 1 fuel element composite chemical impurities in parts per million.

All graphite components in the element were graphitized at $2,800^{\circ} \mathrm{C}$. The total thermal neutron absorption cross-section equivalent of the graphite impurities was less than $5 \mathrm{ppm}$ natural boron by weight. The density of the sleeve was $1.94 \mathrm{~g} / \mathrm{cm}^{3}$, and the density of the compact was $2.11 \mathrm{~g} / \mathrm{cm}^{3}$.

Peach Bottom-FRC-0004 (see Reference 6) gives a fuel compact graphite matrix density of $1.71 \mathrm{~g} / \mathrm{cm}^{3}$ and a spine density of $1.85 \mathrm{~g} / \mathrm{cm}^{3}$.

PB-0066 (see Reference 4) does not specify which type of fuel element these weights in Table 3 are for. To arrive at the total weight of $41 \mathrm{~kg}$, the fuel compact weight should be multiplied by 30 , the number of compacts. "Fuel compact assembly" probably refers to just the solid spine or the hollow spine filled with poison compacts and graphite plugs. 
Table 2. Basic components and materials of standard fuel elements (see Reference 5, Section 3.3.1).

Graphite sleeve

Graphite bottom connector

Silicon braze ring

Stainless steel screen

Internal trap assembly, containing:

Porous graphite filler

Graphite pin

Internal trap (graphite)

Four graphite cloth washers

Activated charcoal (about $130 \mathrm{~g}$ )

Graphite trap nut

Lower reflector

Three graphite spines

Thirty fuel compacts

Upper reflector assembly, containing:

Graphite upper reflector

Porous graphite filter

Graphite retaining ring

National Carbon C-6 cement (a carbonaceous material that is furnace cured) to cement upper reflector to sleeve.

Table 3. Approximate component weights (see Reference 4, Section 3.4.2).

\begin{tabular}{lc} 
Component Weights & Approximat \\
\hline Upper reflector & $6 \mathrm{~kg}$ \\
Sleeve & $13 \mathrm{~kg}$ \\
Lower reflector & $0.6 \mathrm{~kg}$ \\
Internal trap & $2 \mathrm{~kg}$ \\
Bottom connector & $3 \mathrm{~kg}$ \\
Fuel compact assembly & $5 \mathrm{~kg}$ \\
Fuel compact & $0.4 \mathrm{~kg}$
\end{tabular}

The weight of the fuel element is approximately $41 \mathrm{~kg}$. 
Table 4. Core 1 fuel element composite chemical (impurities) ppm (see Reference 4, Section 3.3.2).

\begin{tabular}{lcccr} 
Elements & Upper Reflector & $\begin{array}{c}\text { Sleeve and Bottom } \\
\text { Connector }\end{array}$ & $\begin{array}{c}\text { Lower Reflector and } \\
\text { Trap Assembly }\end{array}$ & $\begin{array}{c}\text { Spines } \\
\text { (max) }\end{array}$ \\
\hline Ash & 32.0 & - & 14.7 & 243.0 \\
Boron & 0.7 & $<5.0$ & 0.1 & 0.4 \\
Iron & 63.5 & $<30.0$ & 1.0 & 1.7 \\
Molybdenum & 7.5 & $<8.0$ & $<1.0$ & $<1.0$ \\
Sulfur & 15.0 & - & 10.2 & 11.0 \\
Titanium & 20.5 & $<20.0$ & $<1.0$ & 32.0 \\
Vanadium & 3.5 & $<6.0$ & 0.4 & 2.4 \\
\hline
\end{tabular}

\subsubsection{Core 1 Standard Fuel Element Compacts}

3.1.2.1 Core 1 Standard Fuel Element Fuel Compacts. The nominal fresh fuel compact is about 3 in. long, with a 2.743 -in. outside diameter, and a 1.750-in. inside diameter. The compact is beveled on both ends and contains 16 equispaced, lengthwise grooves, $0.054 \mathrm{in}$. deep by $0.108 \mathrm{in}$. wide. The compacts were assembled on a spine prior to insertion into a sleeve (see Reference 5).

Thirty fuel compacts, each 3 in. long, were loaded in the 90-in. long fuel area of the standard fuel element. The compacts were loaded onto three graphite spines, each $30 \mathrm{in.} \mathrm{long.}$

The uranium and thorium within the fuel compacts were in the form of carbides uniformly dispersed as coated particles in the graphite matrix. The fuel compacts were fabricated by first warm-pressing to about $750^{\circ} \mathrm{C}$, then sintering at $1,800^{\circ} \mathrm{C}$ in a vacuum. There are four types of compact loadings, as shown in Table 5 (see Reference 5).

Table 5. Core 1 fuel compact initial heavy metal loadings (loading per 3 in. of compact [g]) (see Reference 5, Table 3.1).

\begin{tabular}{|c|c|c|c|c|}
\hline Compact Type & $\mathrm{A}$ & $\mathrm{B}$ & $\mathrm{C}$ & $\mathrm{D}$ \\
\hline Description & Standard & $\begin{array}{c}\text { Heavy } \\
\text { Rhodium }\end{array}$ & $\begin{array}{c}\text { Light } \\
\text { Rhodium }\end{array}$ & $\begin{array}{c}\text { Heavy } \\
\text { Thorium }\end{array}$ \\
\hline Th-232 & 52.10 & 52.10 & 52.10 & 115.36 \\
\hline $\mathrm{U}-234^{\mathrm{a}}$ (maximum) & 0.156 & 0.156 & 0.156 & 0.082 \\
\hline U-235 & 9.700 & 9.700 & 9.700 & 5.140 \\
\hline $\mathrm{U}-236^{\mathrm{a}}$ (maximum) & 0.052 & 0.052 & 0.052 & 0.028 \\
\hline $\mathrm{U}-238$ & 0.505 & 0.505 & 0.505 & 0.268 \\
\hline Rh-103 & 0.0 & 1.028 & 0.342 & 0.0 \\
\hline Carbon & 285.00 & 285.00 & 285.00 & 273.00 \\
\hline
\end{tabular}


3.1.2.2 Core 1 Standard Fuel Element Poison Compacts. The cylindrical burnable poison compacts in the hollow spines of some elements (Type III-see Section 3.1.4) initially contained $0.436+/-0.030 \mathrm{~g}$ of natural boron in the form of zirconium diboride pressed into a graphite matrix. The maximum zirconium diboride particle size was 100 microns. As shown in Figure 5 the burnable poison rods (compacts) were 2 in. long (see Reference 5).

While a document clearly stating the number of burnable poison compacts in a (Type III-see Section 3.1.4) element was not located, the following information was found. The burnable poison compacts were 2 in. long. Figure 4 shows threads in each end of the hollow spine sections for 1-in. graphite caps or "plugs" used to retain the burnable poison compacts. With 2 in. of each of the three hollow spine pieces used for these threaded caps, only 84 in. would be available for the poison compacts. This would provide a loading of 42 compacts at $0.436 \mathrm{~g}$ of natural boron each for a total of $18.3 \mathrm{~g}$ of natural boron at beginning of life (BOL) per element. This agrees with the figure given in the source documents discussed under Section 3.1.4.

Reference 5 contains additional detailed information on loading tolerances for the fuel compacts.

\subsubsection{Core 1 Standard Fuel Element Fuel Particles}

The fuel particles consisted of uranium-thorium carbide substrates (or kernels) 100 to 485 microns in diameter coated with $55+/-10$ microns of pyrolytic carbon. The total carbon within the substrate was between 11 and $16 \mathrm{wt} \%$. The uranium was initially $93.15 \% \mathrm{U}-235$. The substrates are generally referred to as the particle kernels. The size distribution of the particles was selected so that the volume fraction of coated particles in the compact did not exceed $30 \%$ of the total compact volume (see Reference 5).

Each standard fuel element contained 30 annular fuel compacts, which were composed of fuel particles in a graphite matrix material. The kernels in the fuel particles were mixed thorium - highly enriched uranium carbide. Core 1 fuel particles were coated with a single layer of pyrolytic carbon (see Reference 3).

There are inconsistencies in reference sources regarding the reason for the carbon coating. Reference 3 states it is solely to prevent hydrolysis during manufacture. Reference 11 states it also is more retentive of fission products (than particles without this coating). There are also inconsistencies regarding the size ranges of the particles and the particle kernels, and there are inconsistencies about the composition of the kernels.

Some documents present that the uranium and thorium were in separate particles. There are several possible reasons for this misunderstanding. First, documents regarding Core 1 often discuss the particle composition in a way that isn't clear about the combination of thorium and uranium in the kernels. There are some clearer statements about the Core 2 particles, which are discussed later in this summary (see Section 3.3.3). Second, some source documents refer to different fertile and fissile particles. In this case, it means that fissile particles were those with a lower $\mathrm{Th} / \mathrm{U}$ ratio and that fertile particles were those with a higher $\mathrm{Th} / \mathrm{U}$ ratio. Third, some test elements, discussed elsewhere, did have separate uranium carbide and thorium carbide particles. There is more documentation available on the test elements than there is on the standard fuel elements - and quotes taken out of context often are not clearly identified as being only about the test elements. Because the combination of uranium and thorium within the particles is significant to fuel reprocessing considerations, below are a number of quotations from sources about Core 1 regarding this.

Reference 11 states, "The fuel compacts for HTGR consist of thorium-uranium dicarbide particles dispersed in a graphite matrix... By using graphite flour bonded with a minimum of binder for the fuel 
matrix material, high temperatures are not required to produce good graphite properties in the compacts. Only $10 \mathrm{wt} \%$ pitch binder is required and after warm pressing only $5 \%$ of it remains, leaving a high-density matrix of $95-\mathrm{vol} \%$ graphite and 5-vol\% carbon... The fuel used in this process is a solid solution of thorium and uranium dicarbides coated with a layer of pyrolytic carbon.... With the development of the more retentive (of fission products) carbon coated thorium-uranium dicarbide fuel particles [for Core 1], the compact fabrication process was altered so the coated carbide particles could be incorporated into the warm pressed graphite matrix."

Reference 2 states, "The compacts contain pyrolytic carbon coated thorium-fully enriched uranium carbide fuel particles."

Reference 9 states, "The uranium and thorium within the fuel compacts are in the form of carbides, uniformly dispersed as particles in a graphite matrix. The size of the $(\mathrm{U}, \mathrm{Th}) \mathrm{C}_{2}$ particles is 120 to 465 microns in diameter. Each particle is pyrolytically coated with a 45 to 65 -micron thickness of dense carbon. This coating protects the fuel material from oxidation reactions during fabrication and serves to increase the retention time of fission products during reactor operation." And "The fuel particles consist of uranium-thorium carbide substrates coated with pyrolytic carbon."

Reference 12 reports on work done on Peach Bottom Core 1 type fuel compacts, "The fuel used was uncoated particles of (Th, $\mathrm{U}) \mathrm{C}_{2}(5: 1$ ratio) ranging from 250 microns to 420 microns in diameter." And "A small specimen of Peach Bottom Core 1 fuel material (unirradiated, 100\% broken particles, $\mathrm{Th} / \mathrm{U}=5) \ldots "$

Reference 5 states, "The fuel particles consist of uranium-thorium carbide substrates 100 to 485 microns in diameter coated with 55 +/- 10 microns of pyrolytic carbon."

The coated carbide process involved fewer operations and had the added advantage of producing stable compacts that could be exposed to air without damage due to hydrolysis of the carbide fuel by atmospheric moisture. By omitting cold pressing (which would break the coatings on the fuel particles), a penalty of about $7 \%$ in compact density was paid (see Reference 11 ).

The fuel kernels used in Core 1 were coated with a single pyrolytic carbon coating that is $55 \pm 10$ microns thick (see Reference 5, page 6). The coated particle diameter ranged from 210 to 595 microns, and the volume fraction of the coated particles did not exceed $30 \%$ of the total compact volume (see Reference 4, page 3-6). Operating experience with Core 1 was disappointing. Core 1 operated approximately half of its design lifetime, accumulating 451.5 EFPD. The single pyrolytic carbon coating was susceptible to (1) fast-neutron-induced dimensional changes, (2) damage due to fission product recoil, and (3) gaseous fission product release from the particle. Thus, the single coating was cracked and distorted. In the process of curling and changing dimensions, the broken coatings caused the compacts to distort and swell. The radial expansion of the compacts caused them to bind against the graphite sleeves and caused 90 elements in Core 1 to develop cracked sleeves (see References 4 and 5).

As observed in Table 6,45 to $84 \%$ of the Core 1 particle coatings that were metallurgically examined had failed (see Reference 5).

Table 6 is from examination of four out of 30 compacts from one failed element (C05-05) removed from the core after only $168 \mathrm{EFPD}$. Some recent documents generalize these data to the whole core, without noting that they were from a small sample. Another document (see Reference 13, page 31) which addresses the postirradiation examination of compact number 8 from the fuel element removed from core location D06-01 that was identified as failed in November 1968, states "Metallographic examination of both a longitudinal and transverse section of this compact revealed that $\geq 97 \%$ of PyC coatings were broken." 
Table 6. Summary of Core 1 fuel particle failures-from element C05-05 (see Reference 5, Table 6.4).

\begin{tabular}{cccccc}
\hline & & \multicolumn{3}{c}{ Coatings } & \\
\cline { 3 - 5 } Compact & Compact Condition & $\begin{array}{c}\text { Unbroken } \\
(\%)\end{array}$ & $\begin{array}{c}\text { Damaged } \\
(\%)\end{array}$ & $\begin{array}{c}\text { Broken } \\
(\%)\end{array}$ & $\begin{array}{c}\text { Particle Density } \\
\left.\text { (particles } / \mathrm{cm}^{2}\right)\end{array}$ \\
\hline 25 & Good & 21 & 34 & 45 & 270 to 300 \\
27 & Fair, expanded & 16 & 26 & 58 & 270 to 300 \\
10 & Fair, cracked & 10 & 34 & 56 & 270 to 300 \\
18 & Badly fractured & 7 & 9 & 84 & 400 \\
\hline \multirow{2}{*}{ a. From metallography examination. } & & & & \\
\hline
\end{tabular}

\subsubsection{Core 1 Four Types of Standard Fuel Elements}

Four types of standard fuel elements, based on the number of each compact type used for the elements and their rhodium, boron, thorium, and uranium loadings, were used in Core 1 . The types were as shown in Table 7 which was adapted from a table in Reference 4. Table 8, which was adapted from a table in Reference 4, gives the standard fuel element initial heavy metal loadings for the four different types.

The types are given as I, II, III, IV in this fuel summary. Source documents sometimes use 1, 2, 3,4 instead.

The numbers of each type of element given in the second to the last row of Table 7 are shown in multiple source documents. However, only the initial loading used 588 Type IIs and 60 Type IIIs.

According to Reference 2, page 3-1, shortly after the complete core was loaded, between April 14 and the end of April 1966, 24 Type IIs were removed and replaced with 24 Type III elements, which increased the boron poison loading, "to increase the shutdown margin from 4.1 to 5.8\%." The earliest source documents also show the loading with 588 Type IIs and 60 Type IIIs. Review of fuel storage records indicates that the Type II elements in the following four positions in each of the six core sections were replaced with Type III elements for a total of 24 more Type IIIs: 10-03, 10-09, 14-05 and 14-11. A clear record of what was done with the Type II elements removed in April 1966 was not located. (In Core 2, eight of the Type III elements were replaced with Type II elements. It is not clear which elements these were.)

\subsubsection{Core 1 Instrumented (Standard) Fuel Elements}

Thirty-six fuel elements were instrumented for temperature measurements in various locations in Core 1. Each element was instrumented with two thermocouples - an inconel sheath tungsten-rhenium thermocouple and a $\mathrm{Nb}-1 \% \mathrm{Zr}$ sheath chromel-alumel thermocouple (see Reference 4, page 3-17). Eight of the instrumented fuel elements in Core 1 also contained acoustic thermometers, which are instruments that determine temperature by using the proportionality between resonance frequency of a transmitted sound wave and the temperature of the helium gas in a cavity within the fuel element. Figure 6 illustrates a Core 1 instrumented fuel assembly (see Reference 4).

The instrumented fuel elements are very similar to the Core 1 standard fuel elements. The differences involve the bottom connector and certain internal components, which are slightly modified to allow passage of the thermocouple leads that extend to various axial locations in the instrumented fuel elements (see Reference 4).

The eight elements that had acoustic thermometers were Type 1 and II elements. The acoustic thermometers measured the temperature at the center hot spot height (see Reference 4). 
Table 7. Core 1 fuel element types and number of fuel elements in 804-element Core 1 (see Reference 4, Table 5-2).

\begin{tabular}{|c|c|c|c|c|}
\hline \multirow[b]{3}{*}{ Description } & \multicolumn{4}{|c|}{ Fuel Element Type } \\
\hline & $\mathrm{I}$ & II & III & IV \\
\hline & $\begin{array}{c}\text { Heavy } \\
\text { Rhodium }\end{array}$ & $\begin{array}{c}\text { Light } \\
\text { Rhodium }\end{array}$ & $\begin{array}{l}\text { Light Rhodium with } \\
\text { Burnable Poison }\end{array}$ & $\begin{array}{c}\text { Heavy Thorium, } \\
\text { Light Uranium }\end{array}$ \\
\hline Spine & $\begin{array}{l}\text { Solid } \\
\text { graphite }\end{array}$ & $\begin{array}{l}\text { Solid } \\
\text { graphite }\end{array}$ & Hollow with poison & Solid graphite \\
\hline \multicolumn{5}{|l|}{ Compact type: } \\
\hline $\begin{array}{l}\text { In upper } 9 \text { in. } \\
\text { ( } 3 \text { compacts) }\end{array}$ & A & A & A & $\mathrm{D}$ \\
\hline $\begin{array}{l}\text { In middle } 54 \text { in. } \\
\text { (18 compacts) }\end{array}$ & B & $\mathrm{C}$ & $\mathrm{C}$ & $\mathrm{D}$ \\
\hline $\begin{array}{l}\text { In lower } 27 \text { in. } \\
\text { (9 compacts) }\end{array}$ & A & A & A & $\mathrm{D}$ \\
\hline $\begin{array}{l}\text { Number for nominal core } \\
\text { loading-initial Core } 1 \\
\text { configuration }\end{array}$ & 54 & 588 & 60 & 102 \\
\hline $\begin{array}{l}\text { Number for nominal core } \\
\text { loading-final Core } 1 \\
\text { configuration. }\end{array}$ & 54 & 564 & 84 & 102 \\
\hline
\end{tabular}

Table 8. Core 1 standard fuel element initial heavy metal loadings in grams (see Reference 4, Table 5-1).

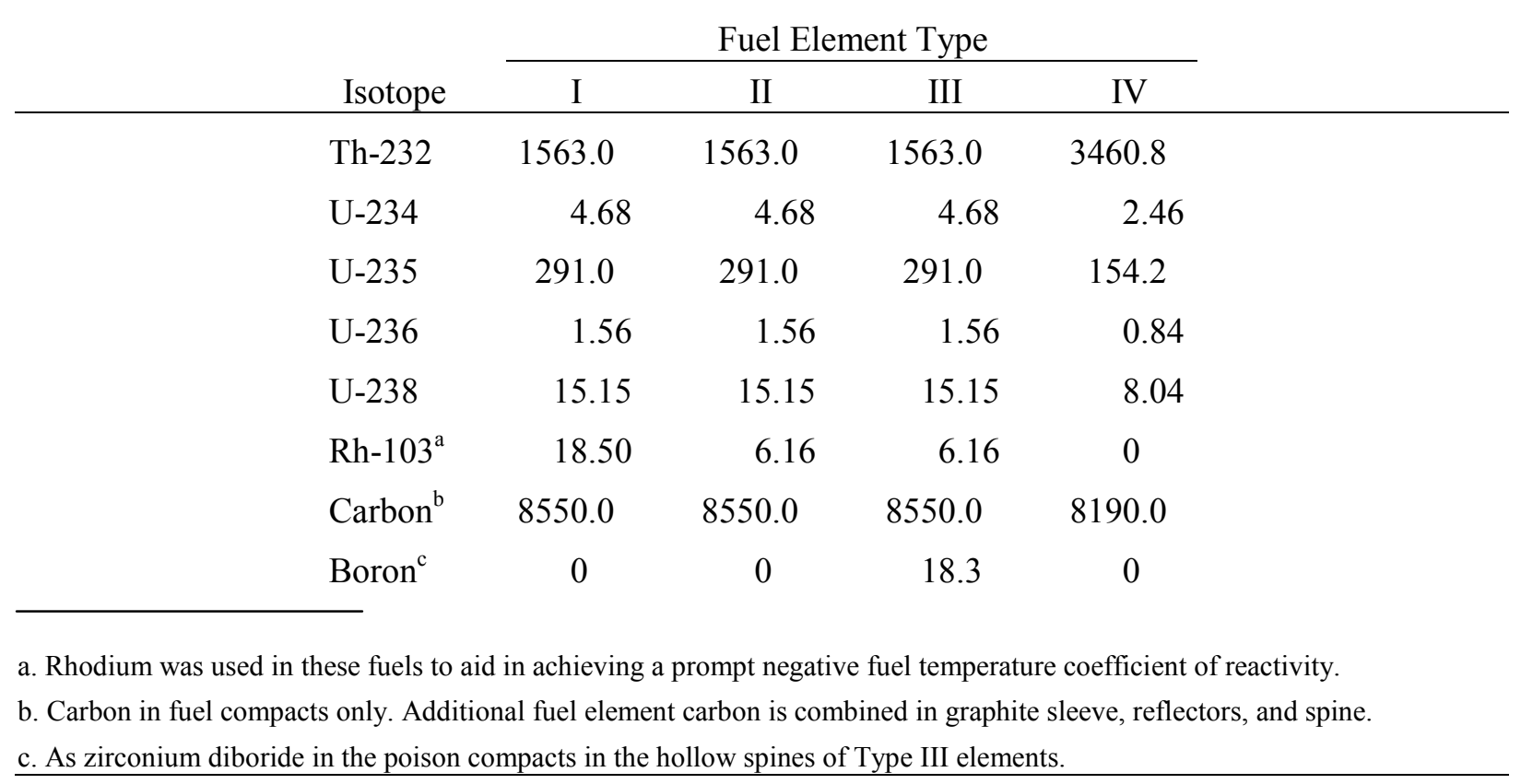



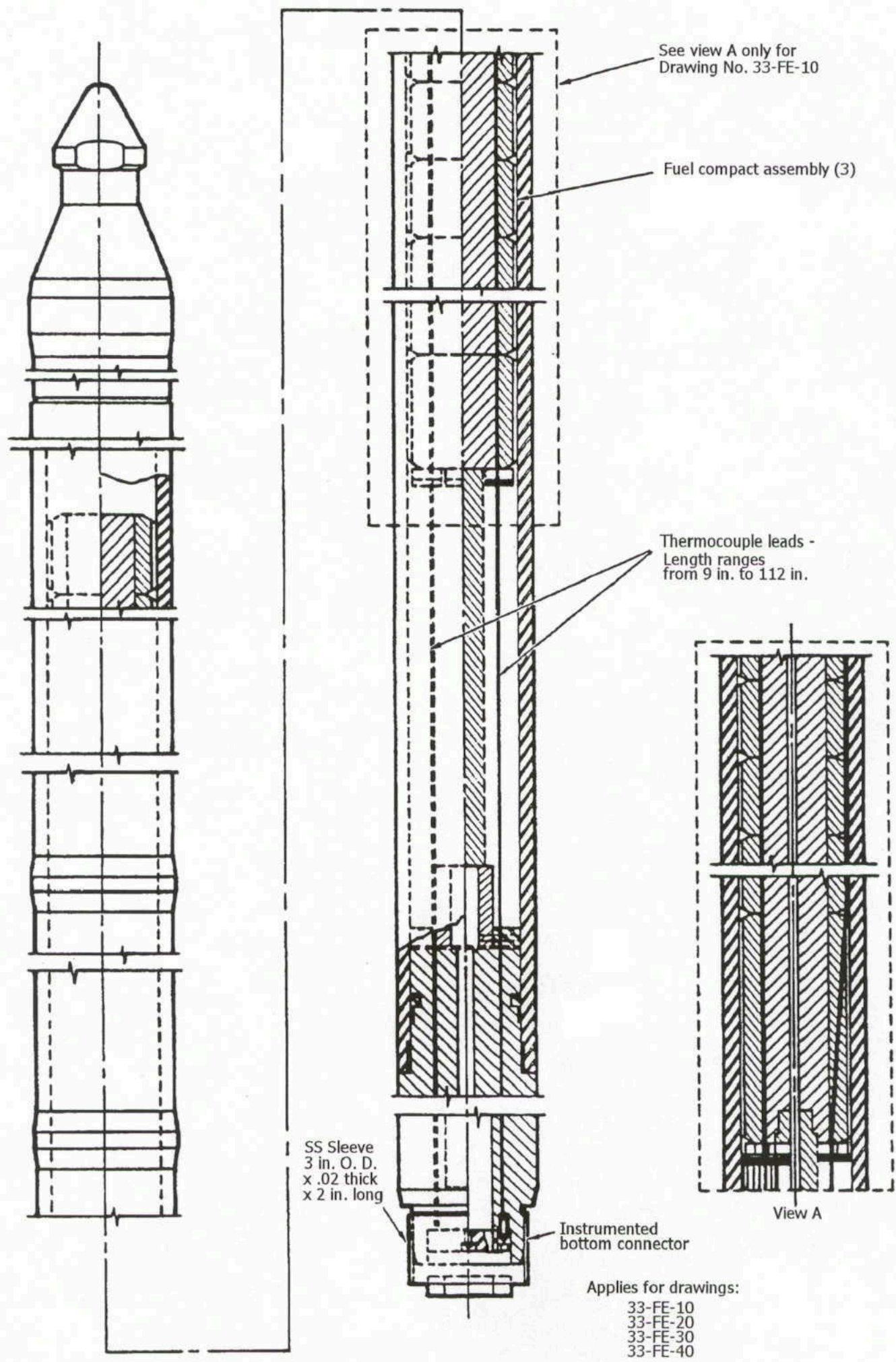

Figure 6. Peach Bottom HTGR Core 1 instrumented fuel assembly (see Reference 4, Figure 3-3). 


\subsubsection{Core 1 Test Elements}

A concise description of the Core 1 test elements was not found in any single document. The following summary was compiled from several sources.

There were only two test elements, PTE-1 and PTE-2, irradiated in Core 1. These were proof test elements (PTE) for FSV. (FSV, an HTGR reactor in Colorado, was under development at the time.) Reference 14 describes PTE-1, which was only irradiated 4 EFPD, then removed from the core. No documents about the examination of PTE-1 postirradiation were located. More postirradiation information about PTE-2 was found. PTE-2 was put into Core 1 some time after PTE-1 was removed. Reference 2, page 5-5, states that because of high activity readings FSV PTE-1 was removed shortly after it was installed. Removal of PTE-1 did not improve the activity readings. While PTE-1 was probably suspected to have failed, causing the high activity, there is no indication that it did, in fact, fail in the core.

PTE-2 was left in the core for part of the Core 2 run. PTE-2 was destructively examined and was not sent to the INEEL. See Figure 20 of a PTE design in Section 3.3.6, "Core 2 Test Fuel Elements."

PTE-1 was an unpurged hexagonal graphite block containing bonded bed fuel rods (columns of coated fuel particles packed to a high bulk density and bonded together by a carbon matrix). An advanced prototype test element containing various types of fuel rods was fabricated for the testing in the Peach Bottom reactor. The active portion of the element consists of four hexagonal graphite blocks that are 3.54 in. wide, each containing 12 fuel holes and 7 coolant holes. The blocks are joined to form a continuous active length of 89 in. There were several types of fuel particles used in PTE-1, some with a buffer isotropic (BISO) coating (an inner lower density carbon layer and outer pyrolytic carbon coating discussed in detail under Core 2) and some called TRISO (tricoating isotropic) with a layer of silicon carbide within the isotropic pyrolytic carbon coating. Some of the particles had mixed uranium-thorium carbide kernels, and some had thorium carbide kernels.

"Piggyback" samples of various fuel and graphite materials were tested:

- $\quad$ Loose, coated particles of each of the same nine types being used in the fuel rods in PTE-1

- Various particle coatings, both restrained and unrestrained

- $\quad$ Matrix material of each of the four types being used in the fuel rods in PTE-1

- $\quad$ Graphite samples of interest to the Public Service Company of Colorado.

The matrix material samples included Plyophen and furfuryl alcohol/maleis anhydride binders and graphite and graphite-charcoal fillers. The piggyback samples are in two locations in PTE-1, fuel Zone 3 and fuel Zone 2. The samples in Zone 3 are located in the center of annular fuel rods in Hole 7. This zone contains all four types of samples. The samples are 1/8 in. in diameter and occupy a total length of $17 \mathrm{in.}$ (see Reference 14, Figure 46). The samples in Zone 2 are discs, which are inserted between fuel rods in Hole 2. The discs are made of various graphites, and each is nominally $1 / 2 \mathrm{in}$. in diameter and 1/8 in. thick. Reference 14 provides over 100 pages of additional detail about PTE-1.

PTE-1, which was received in Peach Bottom fuel shipment No. 11 with Core 2 fuel, contains $414.5 \mathrm{~g} \mathrm{U}-235$, a higher amount than other Core 1 or Core 2 elements. It was, therefore, stored by itself in a canister in the IFSF at the INEEL. The enrichment is the same as standard Peach Bottom fuel elements. ${ }^{15}$ 
PTE-2 consisted of seven graphite components. From bottom to top, these included a bottom connector, a bottom reflector, four fuel bodies, and a top reflector. Fuel bodies one, three, and four were made from H-327 nuclear-grade graphite. Fuel body two was fabricated from Speer 9567 nuclear-grade graphite. The bottom portion of the test element was cylindrical. The remainder of the element had a hexagonal geometry. PTE-2 included a Chromel/Alumel thermocouple and a W/Re thermocouple. PTE-2 had an initial thorium loading of $2152.62 \mathrm{~g}$ and an initial uranium loading of $450.0 \mathrm{~g} .{ }^{16}$

PTE-2 was removed from Core 2 after 402 total Core 1 and Core 2 EFPDs during Core 2 shutdown at 252 EFPD. A circumferential crack about 0.25 in. wide was noted in the bottom connector of PTE-2. This was probably because of insufficient expansion room for an internal metal component in PTE-2 (see Reference 2).

Additional information about PTE-2 is included under Core 2 Test Fuel Elements. PTE-2 was not sent to the INEEL.

\subsection{Core 1 Description}

The following information about core numbers was adapted from Reference 17. This document is unqualified, but provides a better illustration and discussion of the core numbering than was located in original sources.

A plan view of Core 1 showing the configuration at initial criticality is shown in Figure 7. This was developed from Reference 17.

The almost cylindrical core is hexagonally symmetric around the centrally located emergency shutdown rod. Lines have been drawn on Figure 7 to show the hexagonal symmetry, which results in six identical pie-shaped sections of the core labeled A through F. Fuel element locations for each of these sections of the core are identical. For fuel element designation in the core, a three-part identifier is used:

1. The letter designating one-sixth of the core is given, e.g., " $\mathrm{C}$ "

2. Then the number of elements radially outward from the center of the pie shaped portion, along the side of the pie shaped portion, is given, e.g., "C08"

3. Then the number counted from the side of the pie-shaped portion clockwise across the section along a line of elements at a 60-degree angle from the section side is given, e.g., "C08-06."

Ten locations in each portion of the core are identified in Figure 7, by color code, to aid in understanding the designated core locations.

The critical core loading was 682 fuel elements and the Po-Be startup source. The final loading was 804 fuel elements, with 36 control rods and 19 emergency shutdown rods.

Figures 8 and 9 (which are from Reference 6) show the different areas of the core that had the different types of standard fuel elements (Types I, II, III, or IV). However, Figure 9 was based on the original loading with only 60 Type III elements and 588 Type II elements. In Figures 8 and 9, Region 1 had Type I elements, Region 2 had Type II and Type III elements, and Region 3 had Type IV elements. Some sources refer to the Type IV (light uranium, heavy thorium) elements as the "fertile" elements. 


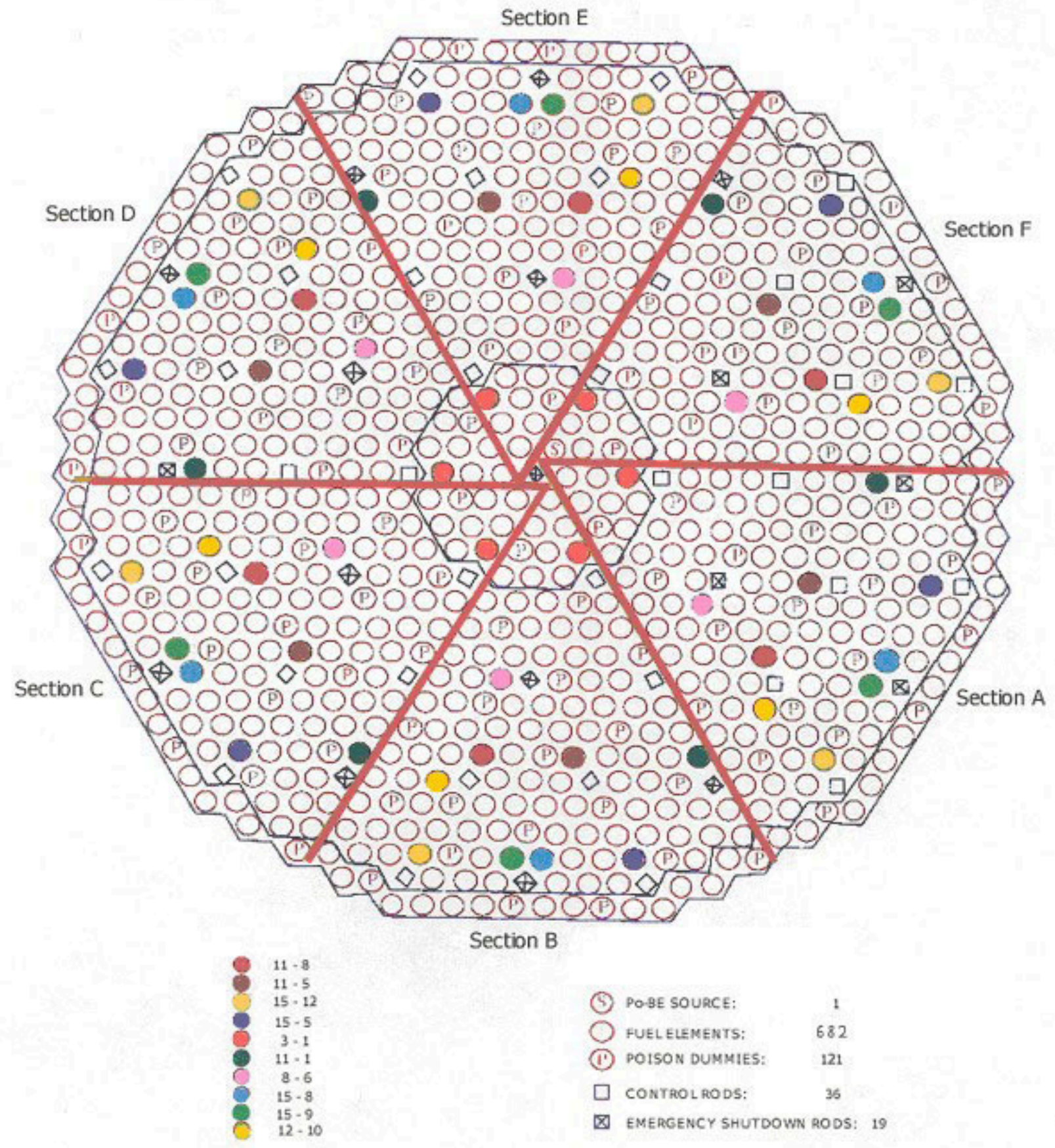

Figure 7. Plan view of Peach Bottom core at initial criticality showing the fuel element identification system. This drawing is just to illustrate the identification system. The final loading was different than what is shown here. This drawing was adapted from Figure 18 of Reference 17. 


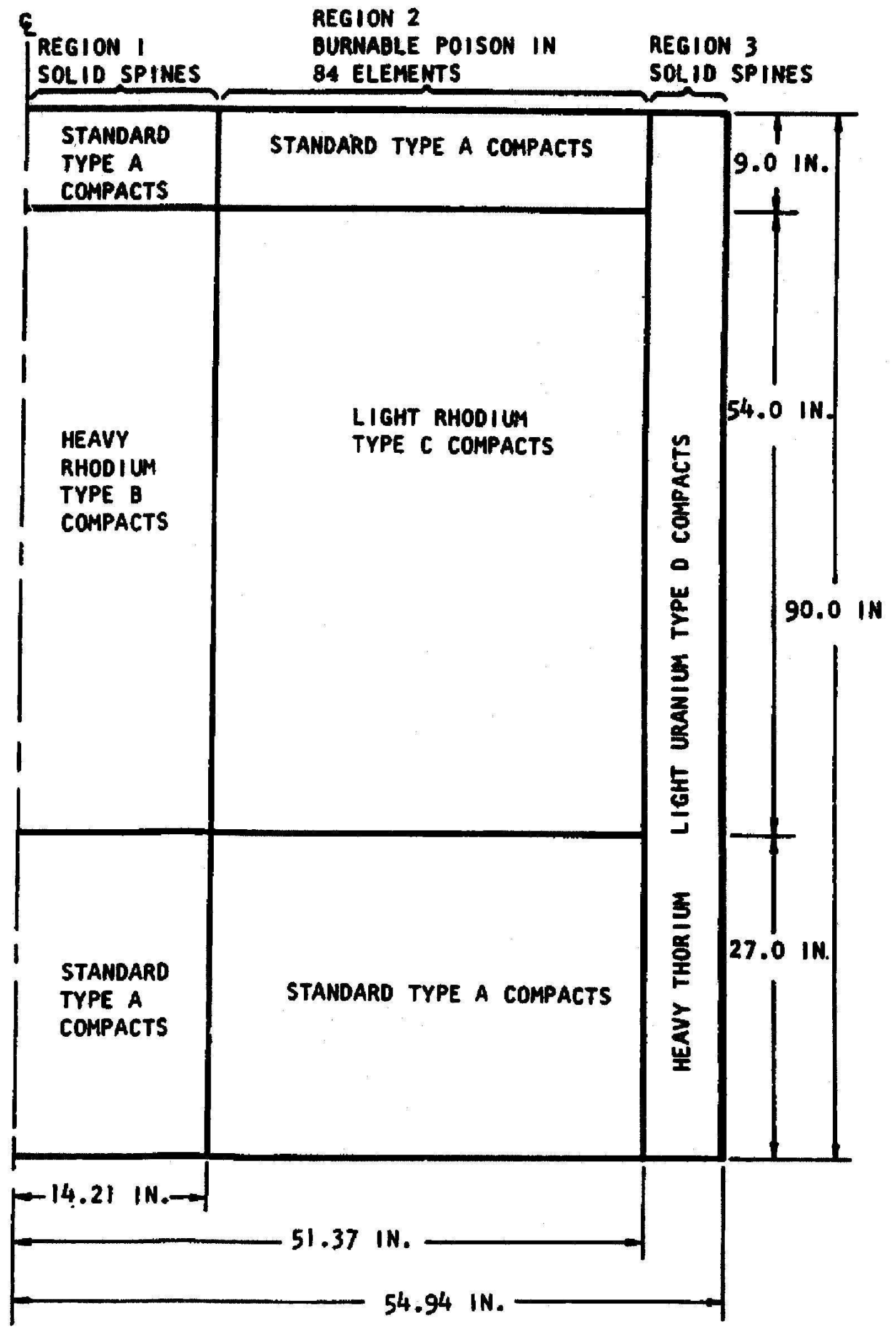

Figure 8. Diagram showing core loading vertically and horizontally (see Reference 6, Figure II-4). 
- O 804 fuel elements

D 36 CONTROL RODS

Q I9 emergency control rods

\begin{tabular}{|c|c|c|}
\hline REGICN I & REGION 2 & REGION 3 \\
\hline - 54 HEAVY RHODIUM ELEMENTS & $\begin{array}{c}588 \text { LIGHT RHODIUM ELEMENTS } \\
60 \text { LIGHT RHODIUM ELEMENTS } \\
\text { WITH POISONED SPINES }\end{array}$ & $\begin{array}{c}\text { IO2 LIGHT URANIUM } \\
\text { HEAVY THORIUM ELEMENTS }\end{array}$ \\
\hline
\end{tabular}

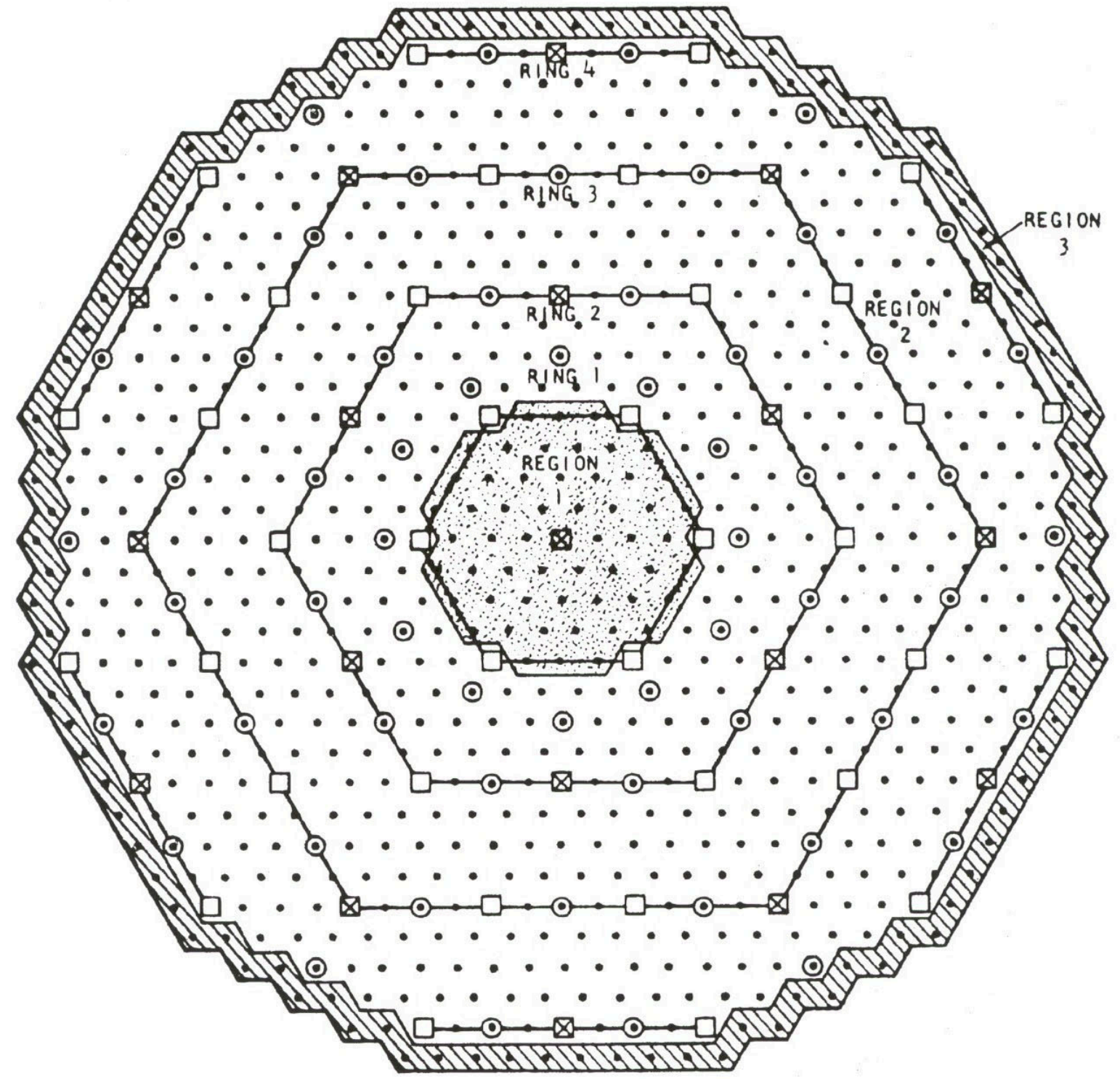

\section{FUEL ELEMENT AND CONTROL ROD POSITIONS}

Figure 9. Map of core showing initial zones for the four different types of standard fuel elements (see Reference 6, Figure II-10). The final loading had 24 more Type III elements and 24 fewer Type II elements than what is shown here. Region 1 contained Type I elements. Region 2 contained Type II and Type III elements and Region 3 contained Type IV elements. 
The boron loading that is given in Table 9 appears to be from the original loading with only 60 Type III elements, rather than 84 as used in Core I. Eighty-four Type II elements would have a total of $1.5 \mathrm{~kg}$ of natural boron.

Table 9. The nominal pre-irradiation core loadings (see Reference 5, Table 3.3).

\begin{tabular}{cc} 
Element & $\begin{array}{c}\text { Loading } \\
(\mathrm{kg})\end{array}$ \\
\hline Th 232 & 1450.0 \\
$\mathrm{U} 234$ & 3.5 \\
$\mathrm{U} 235$ & 220.0 \\
$\mathrm{U} 236$ & 1.18 \\
$\mathrm{U} 238$ & 11.46 \\
Rh 103 & 5.00 \\
B (natural) & 1.10 \\
\hline
\end{tabular}

\subsection{Core 2 Fuel Element Description}

\subsubsection{Core 2 Standard Fuel Element}

A Core 2 standard fuel element is illustrated in Figure 10 (see Reference 4). This drawing does not show the top $18 \mathrm{in}$. of the upper reflector. The drawing was created for characterization of fuel stored at the INEEL. The Core 2 fuel at the INEEL has had the top $18 \mathrm{in}$. removed in order to fit in the IFSF storage canisters at the INEEL.

The design of the Core 2 standard fuel elements was essentially the same as the Core 1 standard fuel elements except for three differences. The first difference is that BISO fuel particles with two layers of carbon coating, instead of one, were used in Core 2 (an isotropic, pyrolytic, carbon outside layer surrounding a low-density, anisotropic coating). The second difference is that the Core 2 compacts do not have the axial grooves included in the Core 1 compacts as evidenced by comparing Figure 5 with Figure 11 (see Reference 4). The axial grooves were placed in the Core 1 compacts to enhance heat transfer but were determined not to be needed. The third difference is that fuel compacts for Core 2 also had slots on the ends not present in Core 1 fuel compacts (see Reference 4). In addition, there may have been slight dimensional differences as discussed in Section 3.1.

The initial heavy metal loadings were lower for Core 2 than for Core 1 . While this is not designated as a design change, it was probably a result of changes in the fuel particles, discussed under Section 3.3.3.

Note, the element for Core 2 location B16-10 had a slightly different design as shown on Figure 10 in View A.

Figures 12 through 17 show details of the Core 2 fuel element design. 


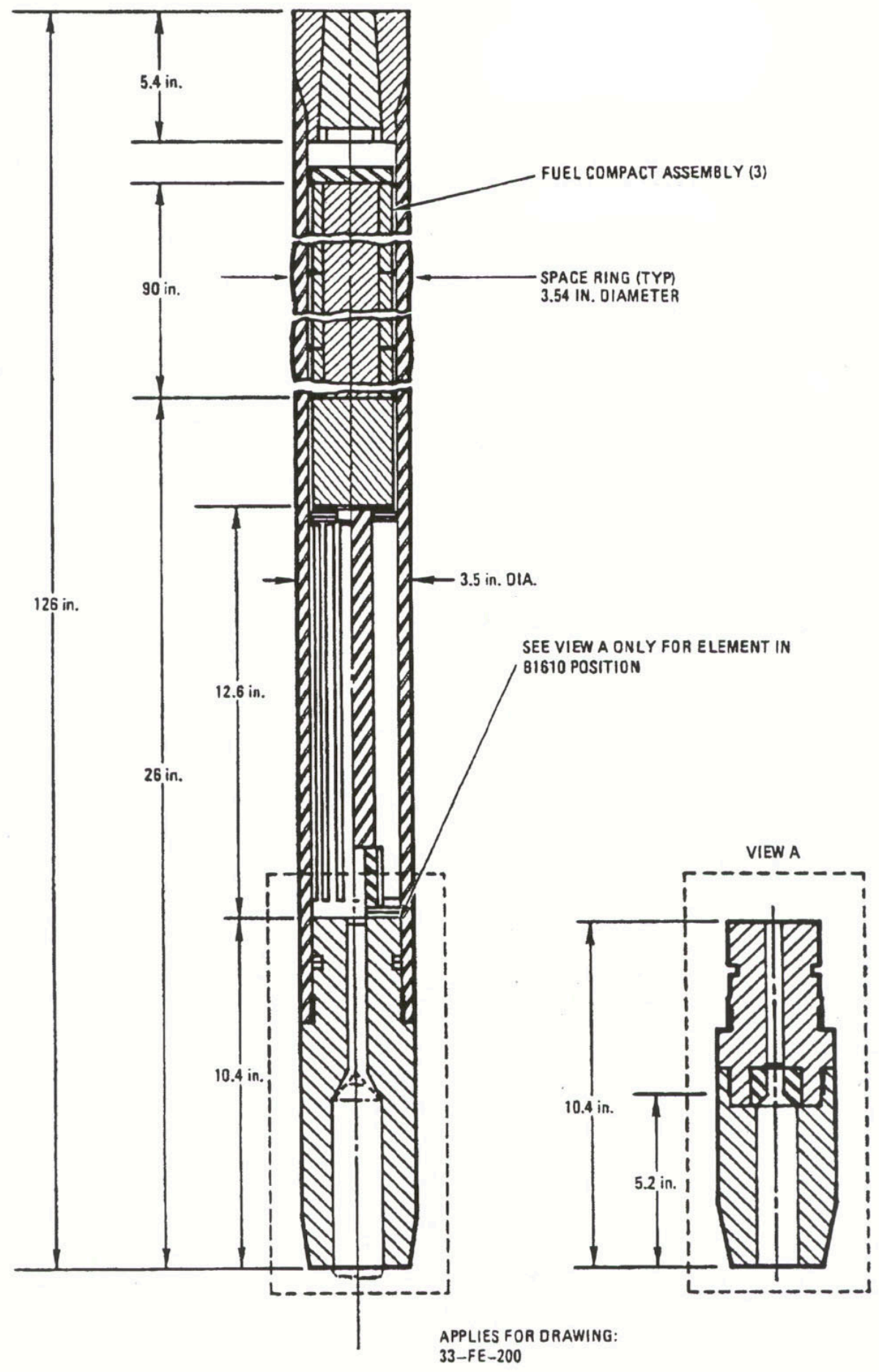

Figure 10. Peach Bottom HTGR Core 2 standard fuel element (as cut for storage in IFSF) (see Reference 4, Figure 3-4). 


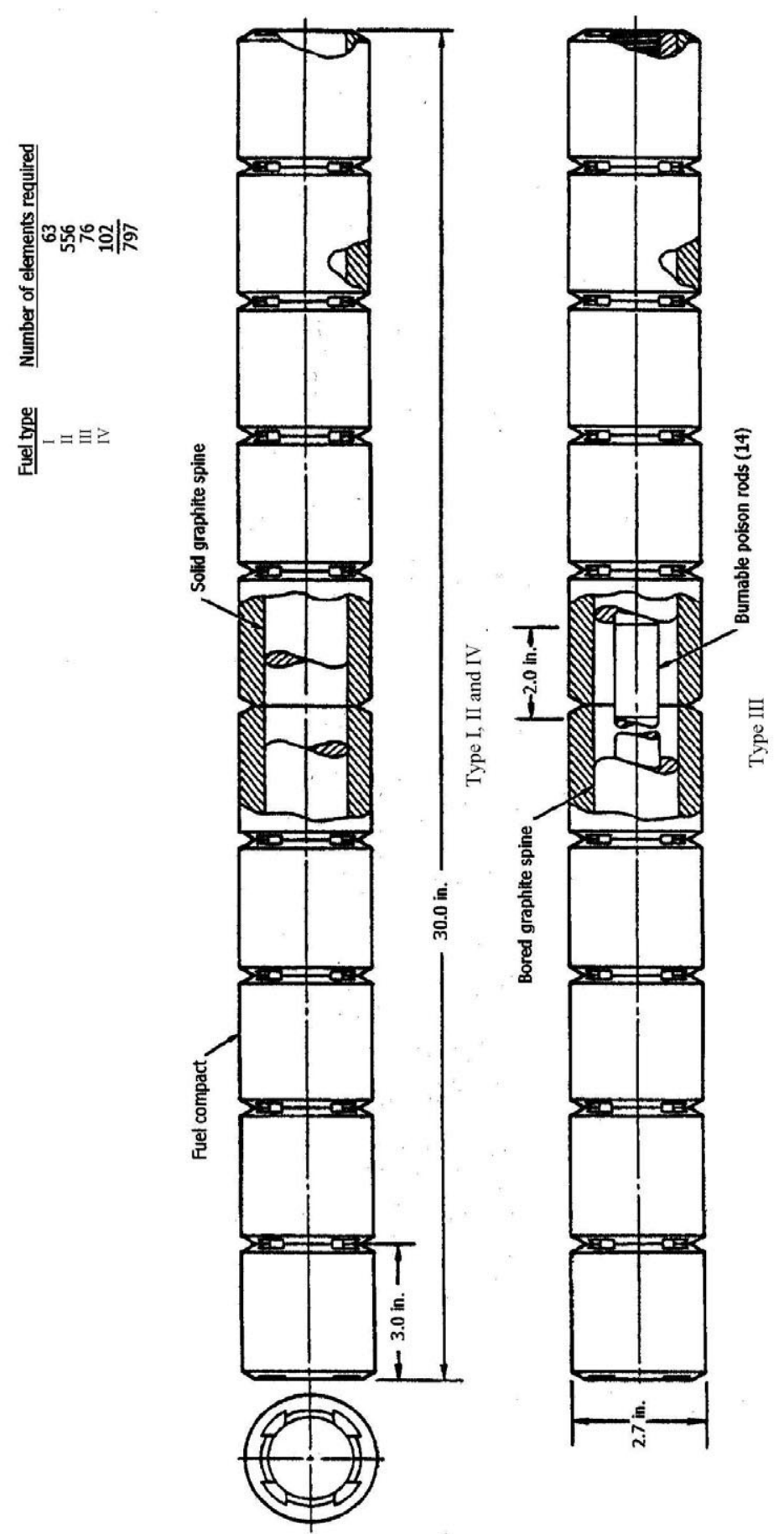

Core 2 fuel compacts. (Note no axial grooves.)

Figure 11. Core 2 fuel compacts stacked on spines (see Reference 4, Figure 3-5). 

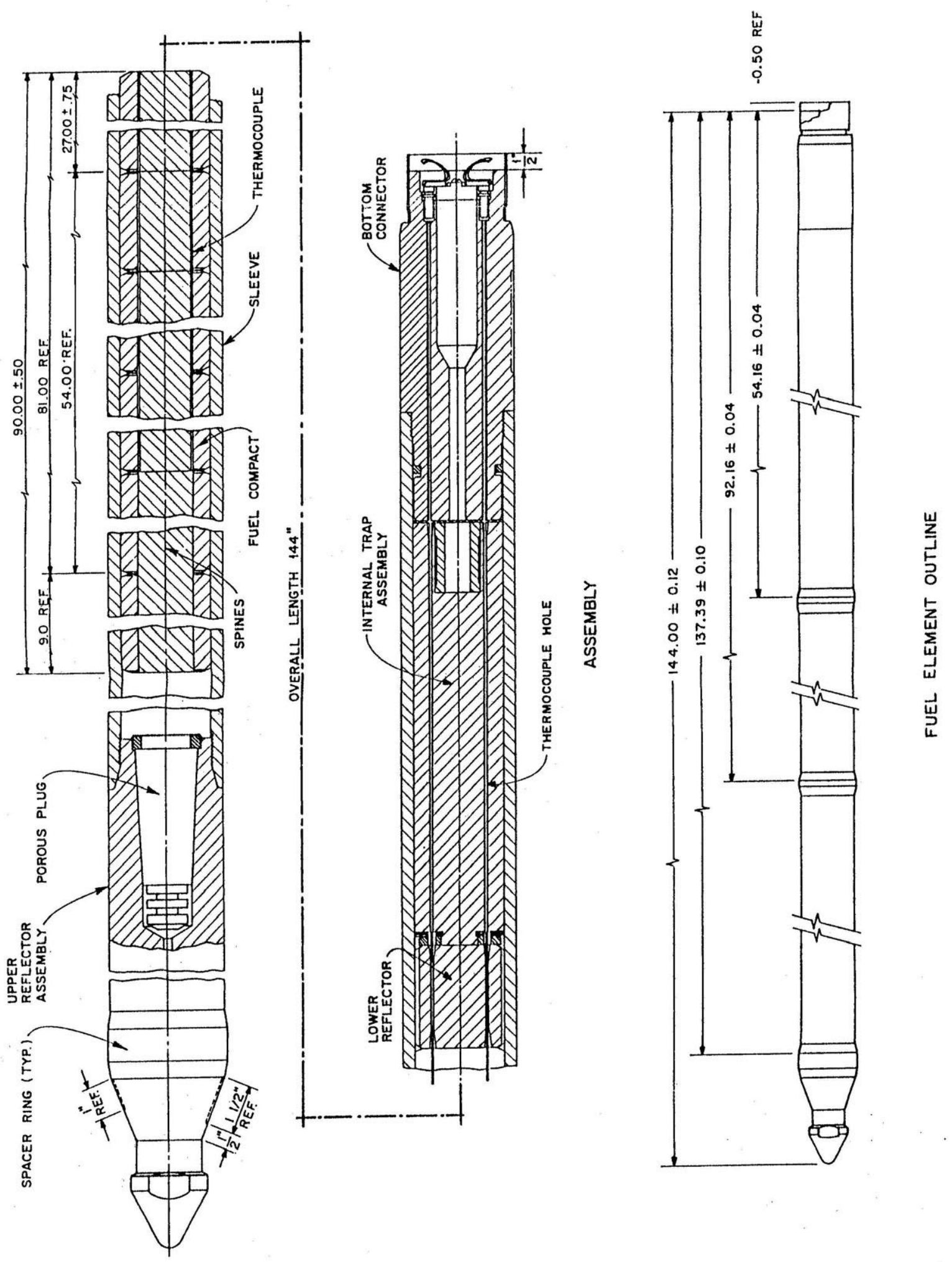

Figure 12. Element E06-01, an instrumented Core 2 standard fuel element (see Reference 8, Figure 2.2). 

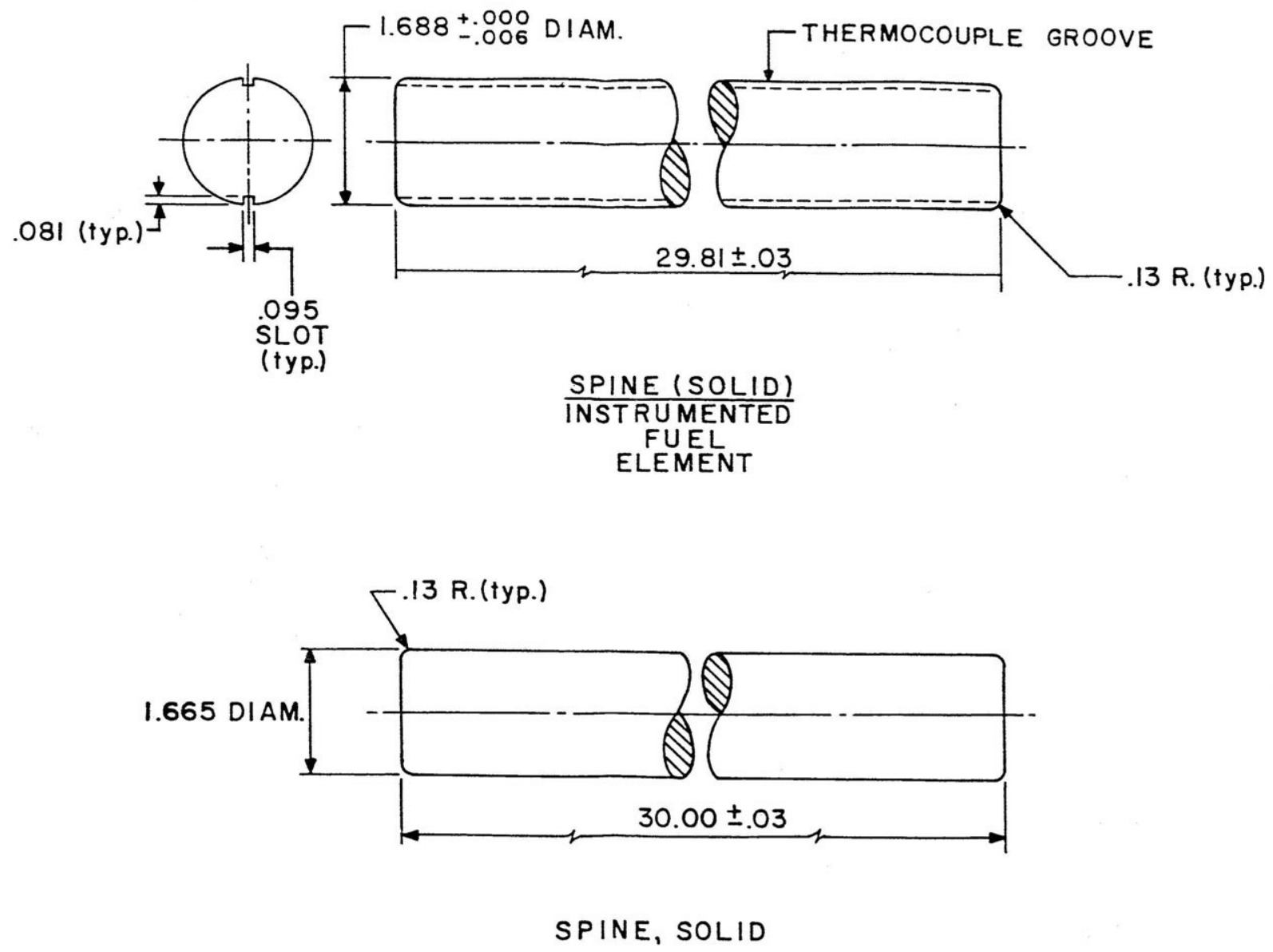

Figure 13. Core 2 spines (see Reference 8, Figure 2.6). 


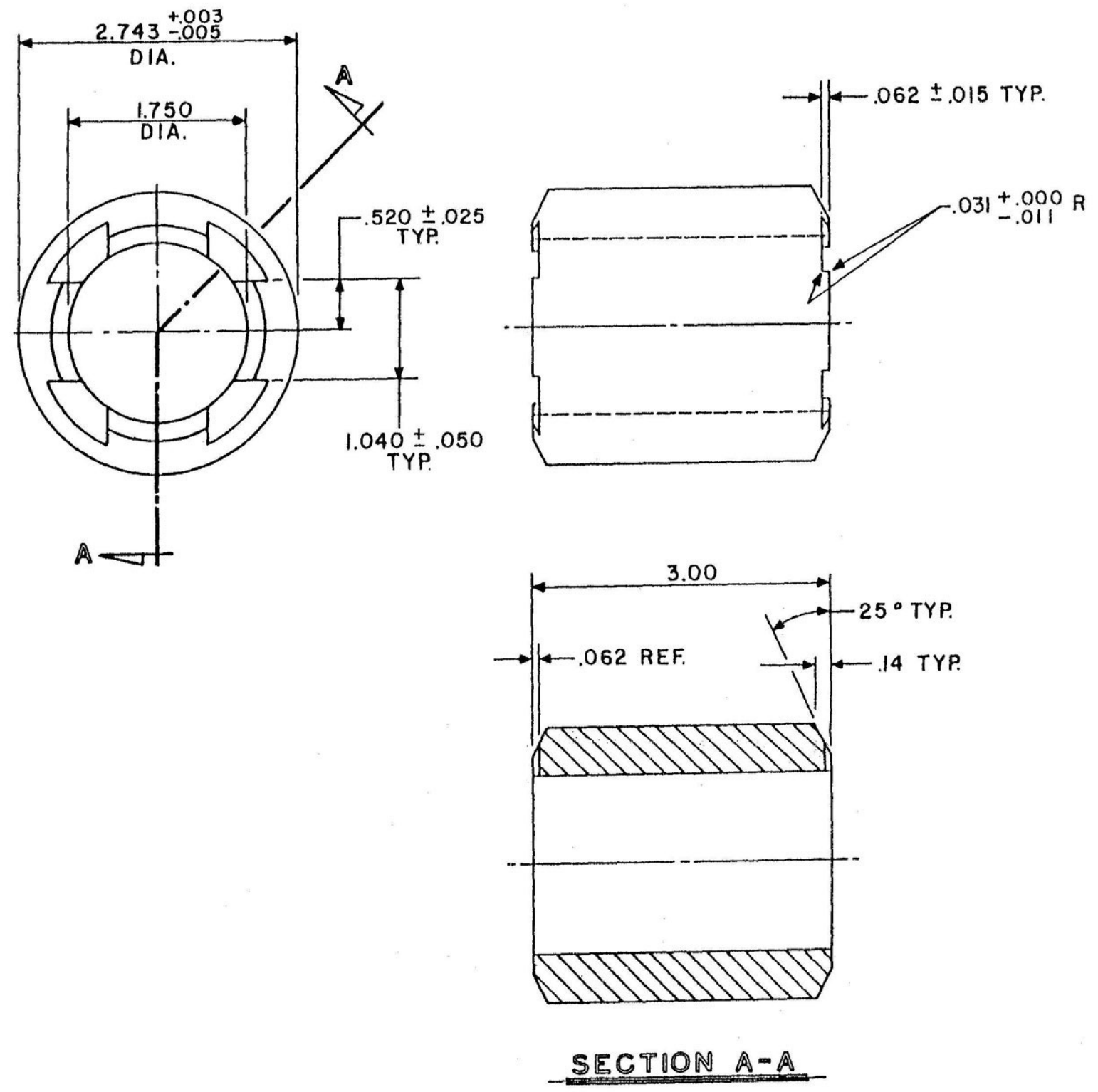

Figure 14. Details of Core 2 compact (see Reference 8, Figure 2.5). 


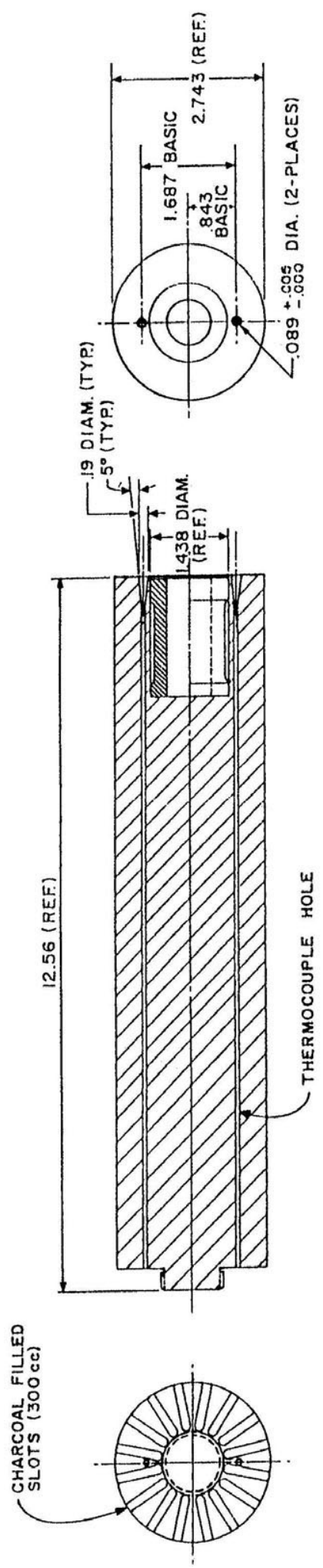

Figure 15. Fission product trap details (see Reference 8, Figure 2.7). 


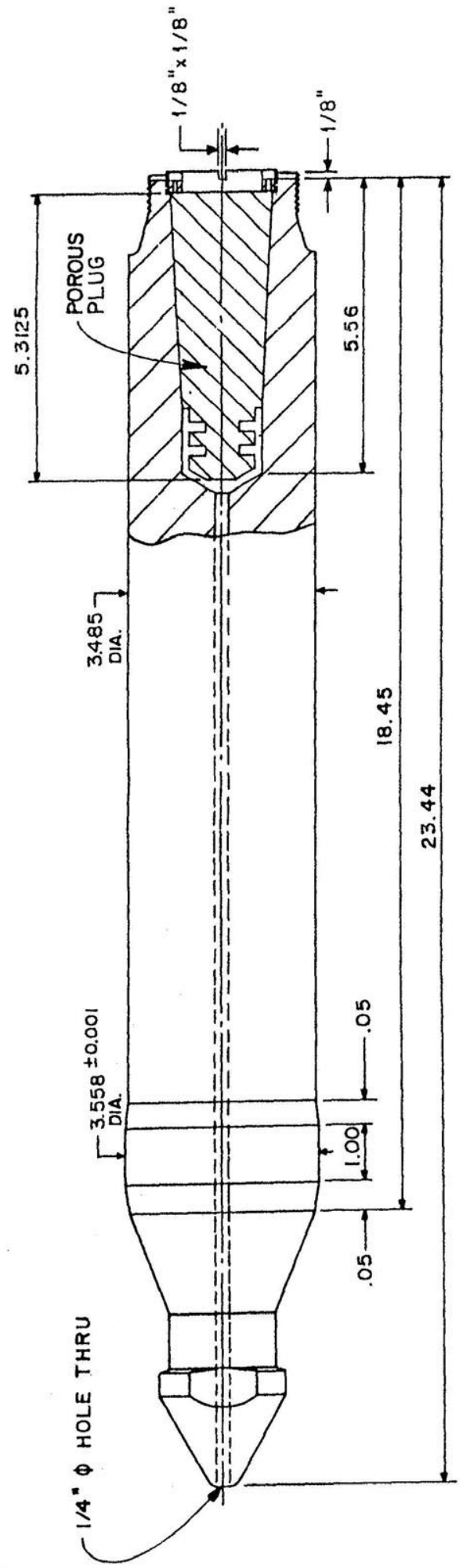

Figure 16. Top reflector assembly (see Reference 8, Figure 2.3). 


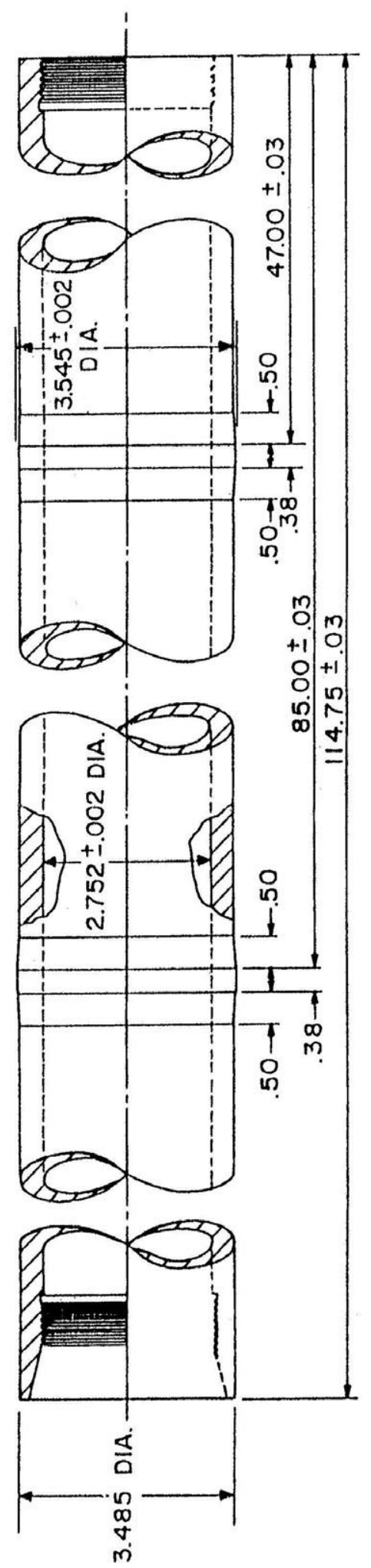

Figure 17. Fuel element sleeve (see Reference 8, Figure 2.4). 


\subsubsection{Core 2 Standard Fuel Element Fuel Compacts}

As discussed under "Core 2 Standard Fuel Element," the Core 2 standard fuel element fuel compacts were essentially the same as the Core 1 standard fuel element fuel compacts except for the following differences. The Core 2 compacts do not have the axial grooves like the Core 1 compacts. The fuel compacts for Core 2 had slots on the ends that were not present in Core 1 fuel compacts. The fuel particles had a different design, and as shown in Table 10, the initial heavy metal loadings were lower for Core 2 than for Core 1.

Table 10. Core 2 fuel compact types initial loading per 3 in. compact (g) (see Reference 4, Table 5.5).

\begin{tabular}{lcccc}
\hline & \multicolumn{4}{c}{ Compact Type } \\
\cline { 2 - 5 } & $\begin{array}{c}\mathrm{A} \\
\text { (Standard) }\end{array}$ & $\begin{array}{c}\mathrm{B} \\
\text { (Heavy Rhodium) }\end{array}$ & $\begin{array}{c}\mathrm{C} \\
\text { (Light Rhodium) }\end{array}$ & $\begin{array}{c}\text { D } \\
\text { (Heavy Thorium) }\end{array}$ \\
\hline Thorium-232 & 45.8 & 45.8 & 45.8 & 86.6 \\
Uranium (93\% enriched) & 8.32 & 8.32 & 8.32 & 4.69 \\
Rhodium & 0 & 1.03 & 0.342 & 0 \\
\hline
\end{tabular}

\subsubsection{Core 2 Standard Fuel Element Fuel Particles}

The fuel particle design was changed for Core 2. A low-density "buffer" carbon layer was coated onto the kernel first and then a high-density, isotropic pyrolytic carbon coating was fabricated over the buffer coating (see Reference 4, page 3-9). This coated particle was named a BISO particle (a photomicrograph of a BISO particle is shown in Figure 18 [see Reference 2). The low-density buffer layer protected the outer layer from damage due to fission product recoil and gaseous fission product release. Under irradiation, the buffer material would shrink providing volume to accommodate fission product accumulation. As a result, only about $3.4 \%$ of the fuel particles failed in Core 2 (see References 3 and 4).

The change in particle design allowed Core 2 to operate to 897.4 EFPD — approximately equal to the planned burnup of 900 EFPD. The Core 2 beginning-of-life (BOL) coated particles are from 340 to 630 microns in diameter with a total (both coatings) coating thickness of 90 to 130 microns (see Reference 4, Section 3.2.3).

In Core 2 the fissile particles have kernels of 5.5:1 (Th-U) $C_{2}$ and are nominally 350 microns in diameter. The fuel elements at the outer circumference of the core (Type IV) contain fertile particles, which are 18.5:1 (Th-U) $\mathrm{C}_{2}$ and are 400 microns in diameter. The coating thicknesses are nominally 120 microns for the fissile particles and 100 microns for the fertile particles. ${ }^{18}$ 


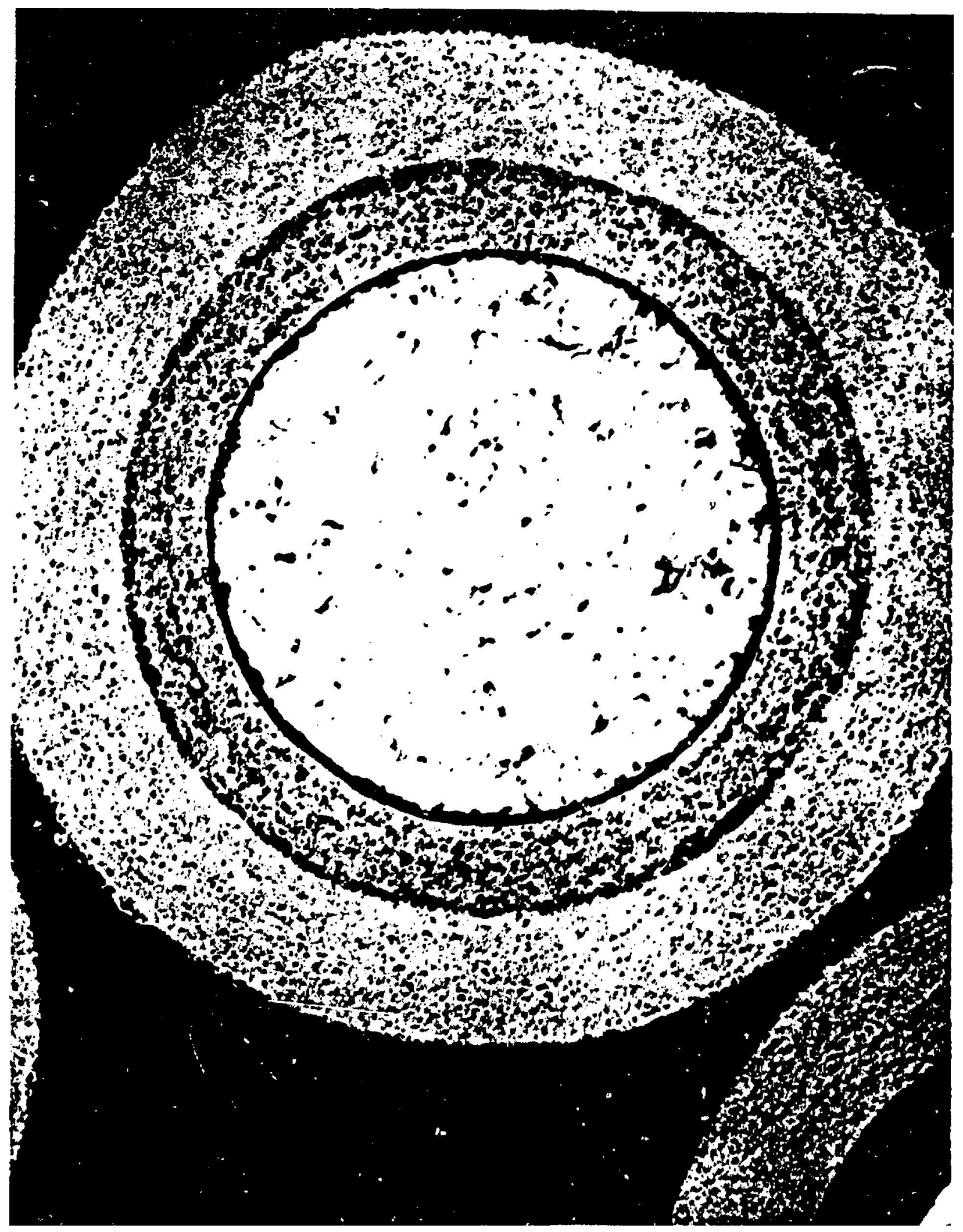

Figure 18. BISO fuel particle of the type used in Peach Bottom HTGR Core 2 (see Reference 2, Figure 2-3). 


\subsubsection{Core 2 Four Types of Standard Fuel Elements}

The four Core 2 standard element types were essentially the same as those for Core 1, except the initial heavy metal loadings were lower as shown in Table 11 (see Reference 4).

Table 11. Core 2 standard fuel element initial heavy metal loadings in grams (see Reference 4, Table 5-4).

\begin{tabular}{lcccc} 
& \multicolumn{3}{c}{ Fuel Element Type } \\
\cline { 2 - 5 } & \multicolumn{1}{c}{ I } & II & III & IV \\
\hline Uranium (93\% enriched) & 249.6 & 249.6 & 249.6 & 140.7 \\
Thorium-232 & 1374.0 & 1374.0 & 1374.0 & 2598.0 \\
Boron & 0 & 0 & 18.31 & 0 \\
Rhodium & 18.54 & 6.16 & 6.16 & 0 \\
\hline
\end{tabular}

\subsubsection{Core 2 Instrumented Fuel Elements}

Both Peach Bottom HTGR Core 1 and Core 2 contained fuel elements that were instrumented with thermocouples. (Acoustic thermometers were used only in Core 1). The core locations used for instrumented fuel were also used for test elements (experimental fuels) that were installed in the core at various times and often moved from one location to another. The table of Core 2 elements in Appendix B includes as much information as could be located about where each element was installed and for how long. The instrumented standard fuel elements for Core 2 are the same design as for Core 1 with the exceptions noted above of the use of BISO design fuel particles, no longitudinal grooves in the compacts, and the addition of slots on the ends of the Core 2 fuel compacts.

Figure 19 (see Reference 4) illustrates the Core 2 instrumented fuel elements as stored in the IFSF at the INEEL.

\subsubsection{Core 2 Test Fuel Elements}

Thirty-three fuel test elements were irradiated in Core 2 to various exposures. Instrumentation in the 33 test elements measured thermal, physics, fission product, and materials behavior of commercial HTGR fuel concepts (see References 4 and 16).

Because the Peach Bottom HTGR Cores 1 and 2 offered unique capabilities as a test facility for HTGR type fuels, test assemblies were tested in the core to evaluate interactions of fuel particles, fuel beds, and graphite structures. Figures 20 and 21 illustrate the three configuration types of test fuel elements that are currently stored at the INEEL. (Plans are in place to eventually receive additional test elements at the INEEL from ORNL and General Atomics.) Two test elements of the PTE type were irradiated in Core 1. The first (PTE-1) was removed from Core 1 after only 4 EFPD and eventually shipped to the INEEL. The second (PTE-2) continued irradiation in Core 2, where an additional 32 test elements were also irradiated. These test elements, which fit into a normal fuel element space in the Core 2 fuel element holes, were manufactured in three classes:

1. Fuel test elements (FTEs), fuel bed test elements (FBTEs), and recycle test elements (RTEs)

2. PTES

3. Fuel pin test elements (FPTEs). 


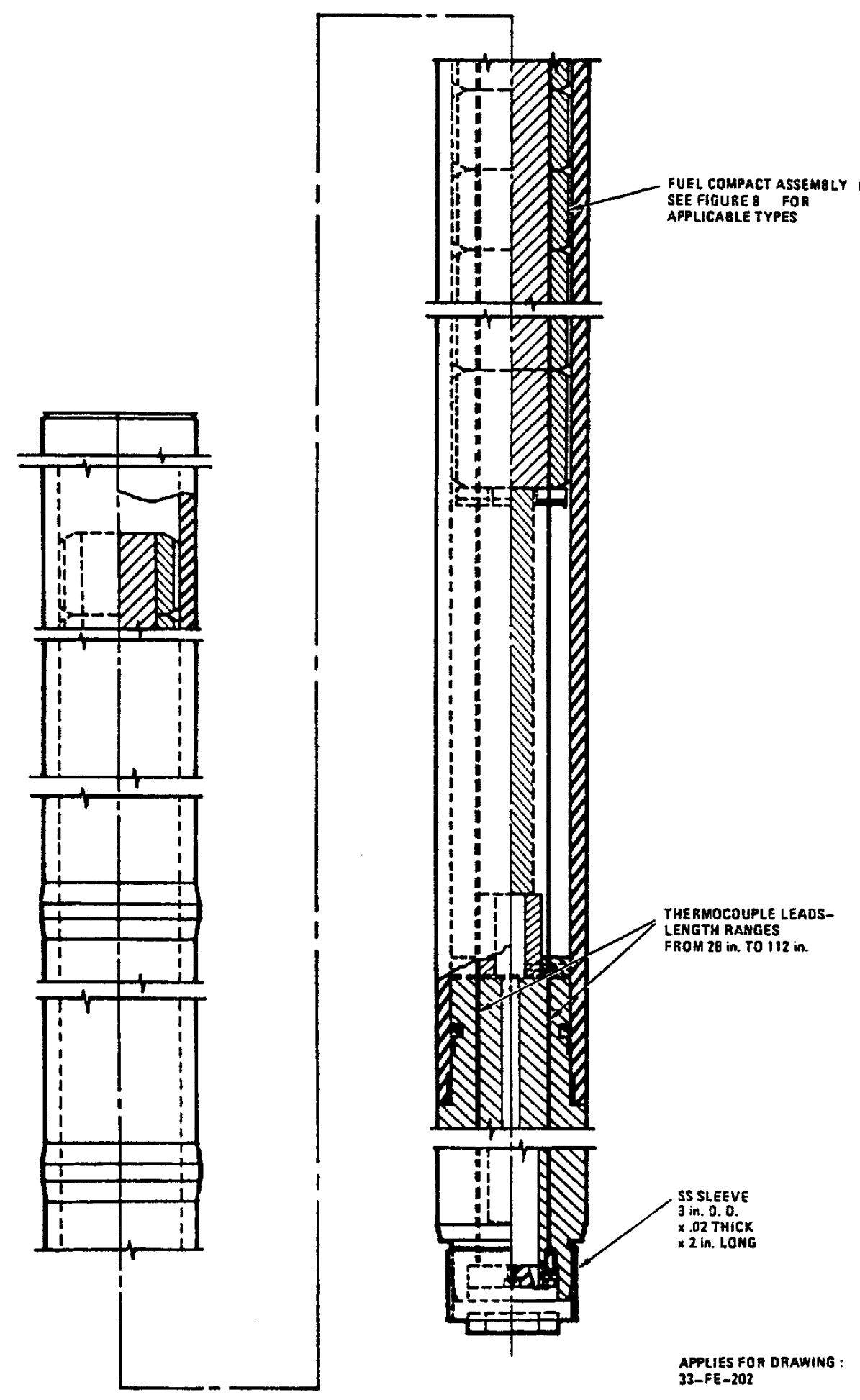

Figure 19. Core 2 instrumented fuel elements as stored in INEEL IFSF (see Reference 4, Figure 3-6). 


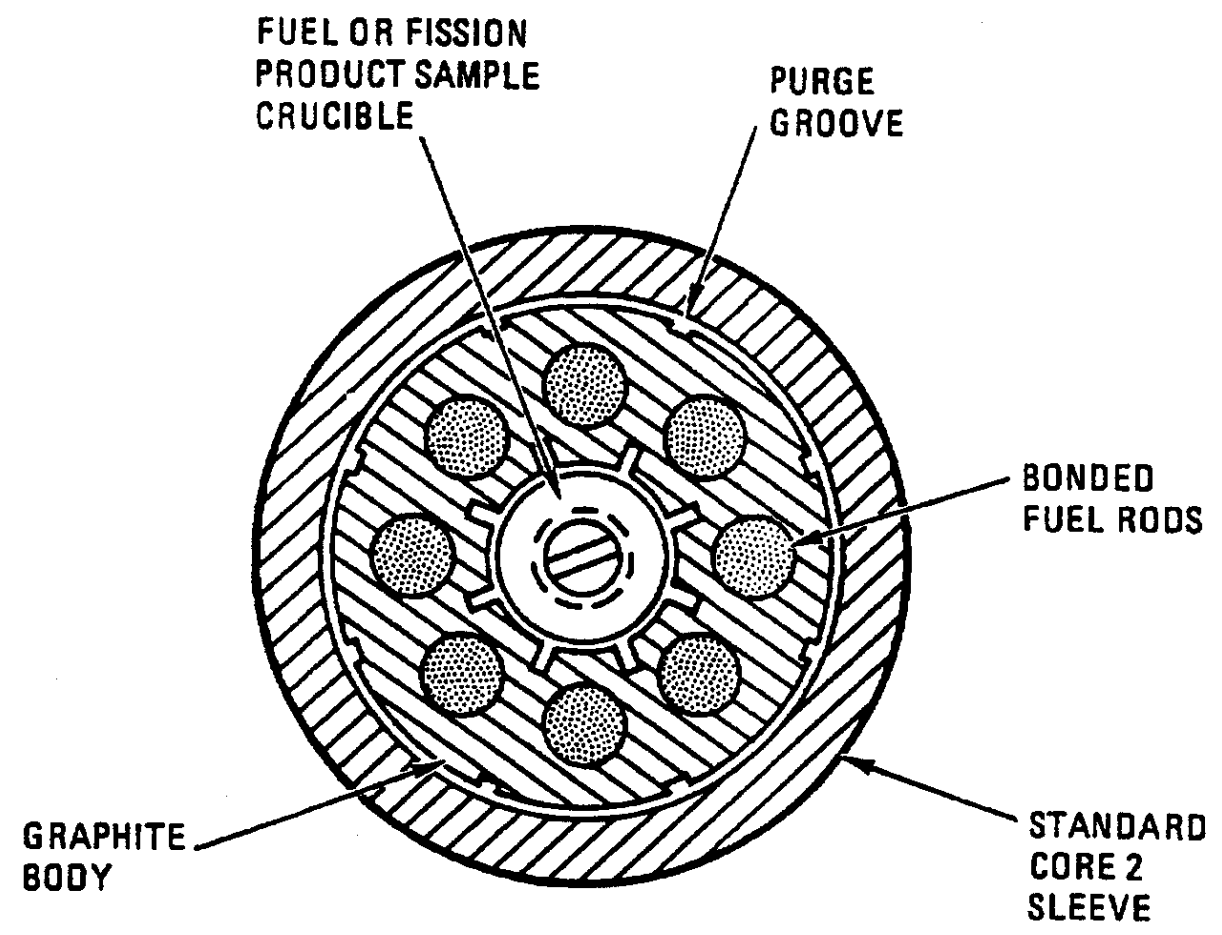

FTE CROSS SECTION

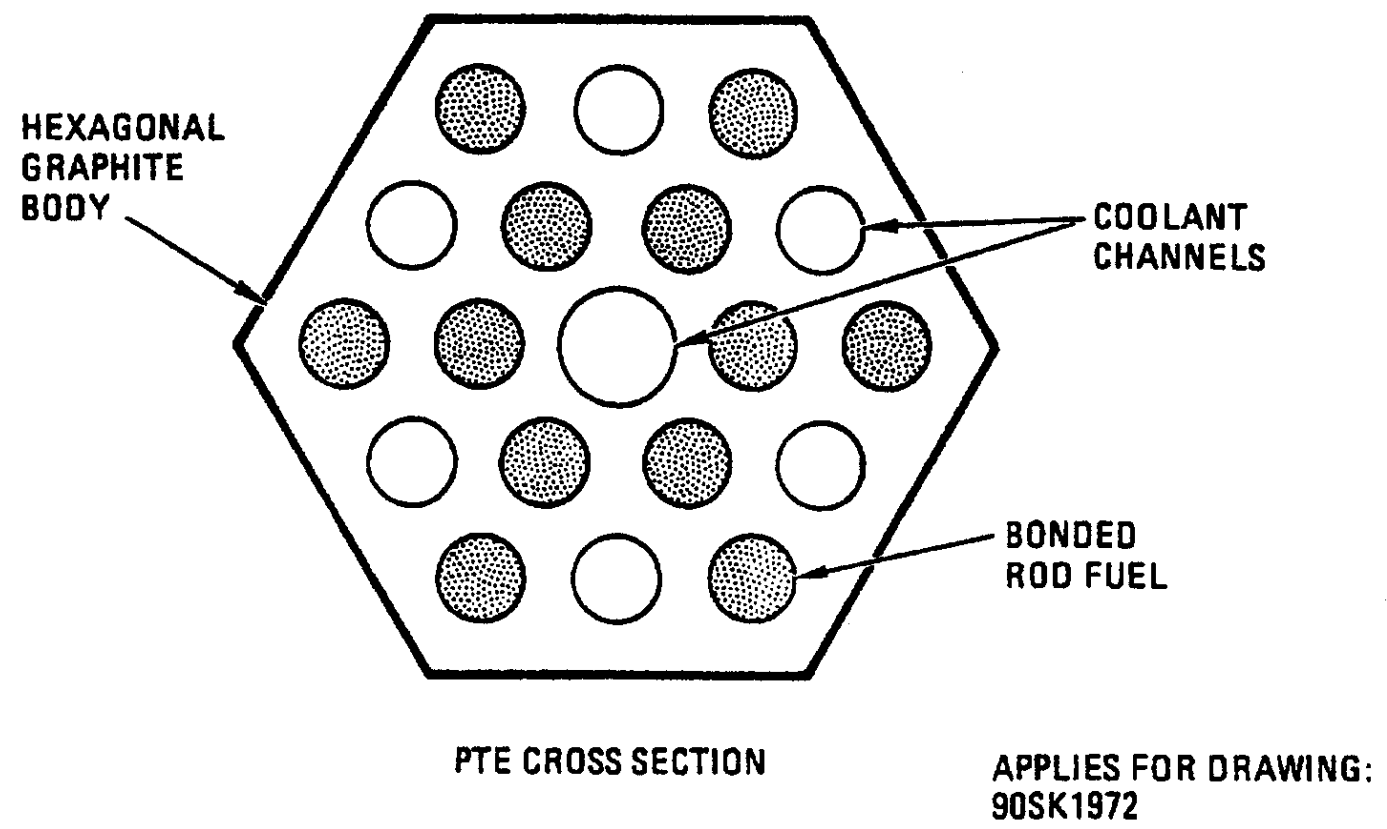

Figure 20. Two configuration types of test fuel elements used in Peach Bottom (see Reference 4, Figure 3-7). 


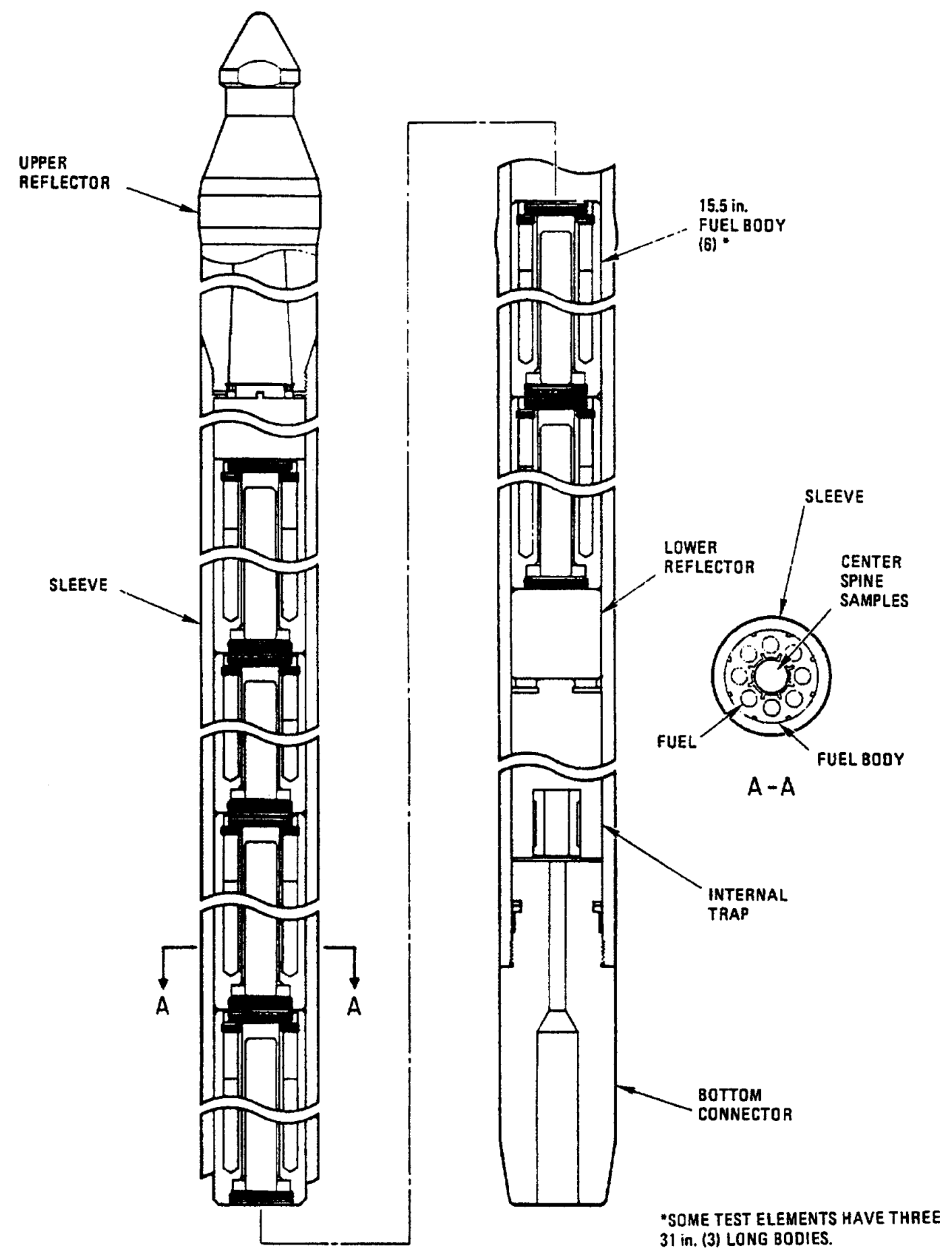

Figure 21. Axial view of six-body FTEs, RTEs, and FBTEs (see Reference 4, Figure 3-8). 
Of the 33 total test elements in Core 2, 30 were of the FTE/FBTE/RTE design, one was of the PTE design (PTE-2), and two were of the FPTE design (see References 4 and 16).

The PTEs are hexagonal as shown in Figure 20 and do not use graphite sleeves. The PTE is made up of four separate fuel sections each containing fuel holes and coolant holes. These four sections together with a top reflector, bottom reflector, and bottom connector were threaded together to form an assembly approximately $3.5 \mathrm{in}$. across the flats and $140 \mathrm{in}$. long. The top and bottom reflectors were designed to allow use of a special handling tool and also contained coolant flow inlets and exits (see References 3 and 13).

The FTEs, FBTEs, and RTEs in storage are externally similar to the standard and instrumented fuel elements. The fueled portion of the test FTE/FBTE/RTE contains six bodies (some test elements contain three bodies) as shown in Figures 21, 22, and 23. These fuel bodies had eight fuel holes surrounding a central hole that contained either fuel rods or loose fuel particles (see References 4 and 16).

The FPTEs were irradiated for the United Kingdom Atomic Energy Authority (UKAEA) and returned to the United Kingdom following their irradiation in Peach Bottom HTGR Core 2 and their postirradiation examination in the United States. Two FPTEs were irradiated in Core 2. Figures 24 and 25 illustrate the FPTE experiment design (see Reference 16).

Test elements contained large quantities of combinations of BISO and TRISO coatings on both oxide and carbide kernels. The TRISO particle type has a layer of silicon carbide within the isotropic pyrolytic carbon coating (see Reference 16). Test elements contained some organic materials, such as the polyethylene spacer shown in Figure 22.

There is extensive documentation regarding the design, performance, and examination of the test elements available. Some of the data are presented here. However, many of the elements were destructively examined and no longer exist in storage as spent fuel elements. Reference 19 has recent information on the status of the Core 2 test elements. Table 12 was extracted from that document. Reference 4 was the source of Table 13. The document did not state the source of the data.

Table 14 of Test Element outer pyrolitic coating densities as a function of fast fluence and temperature is from Reference 16. 


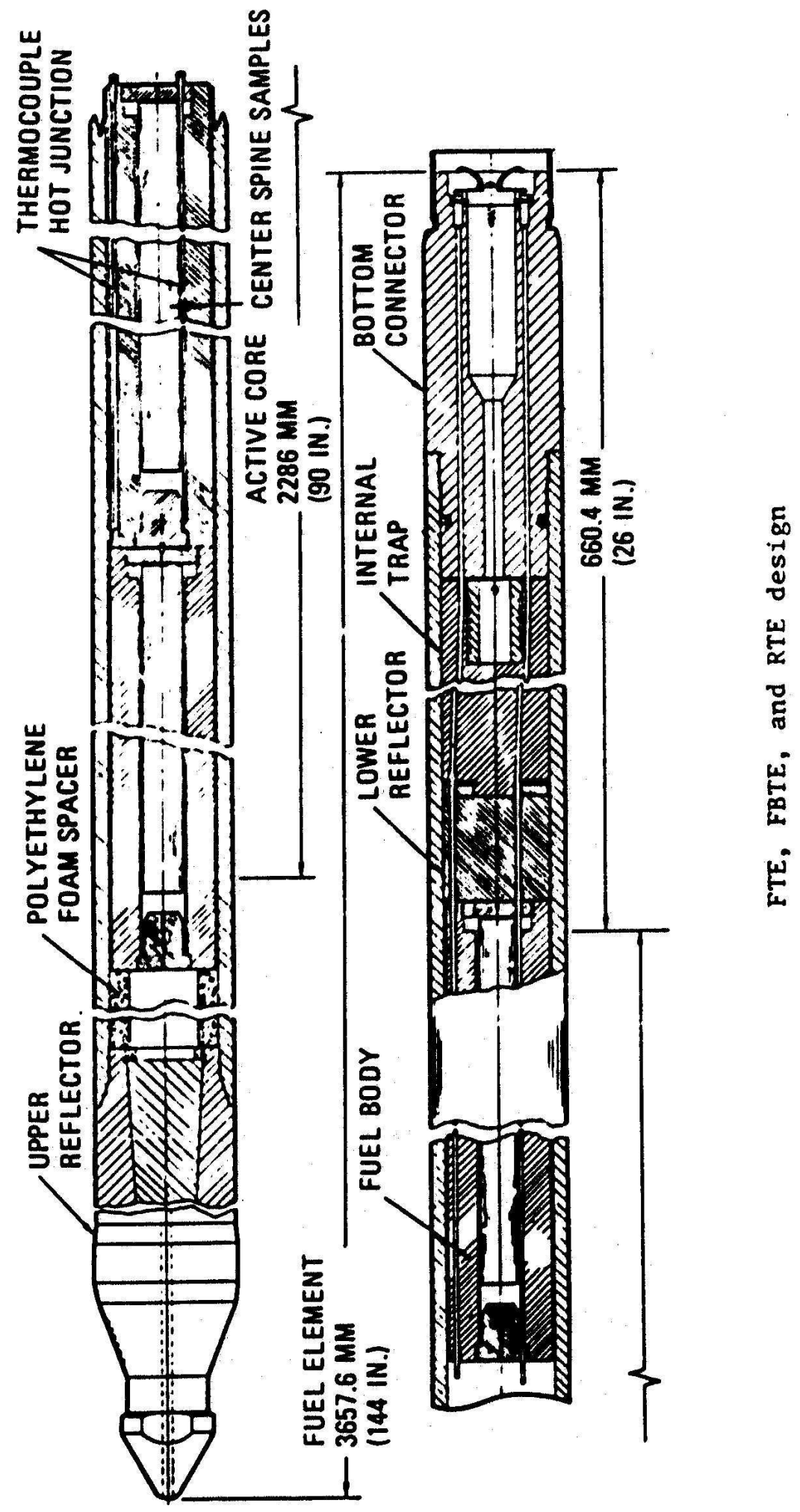

Figure 22. FTE, FBTE, and RTE design (see Reference 16, Figure 2-6). 


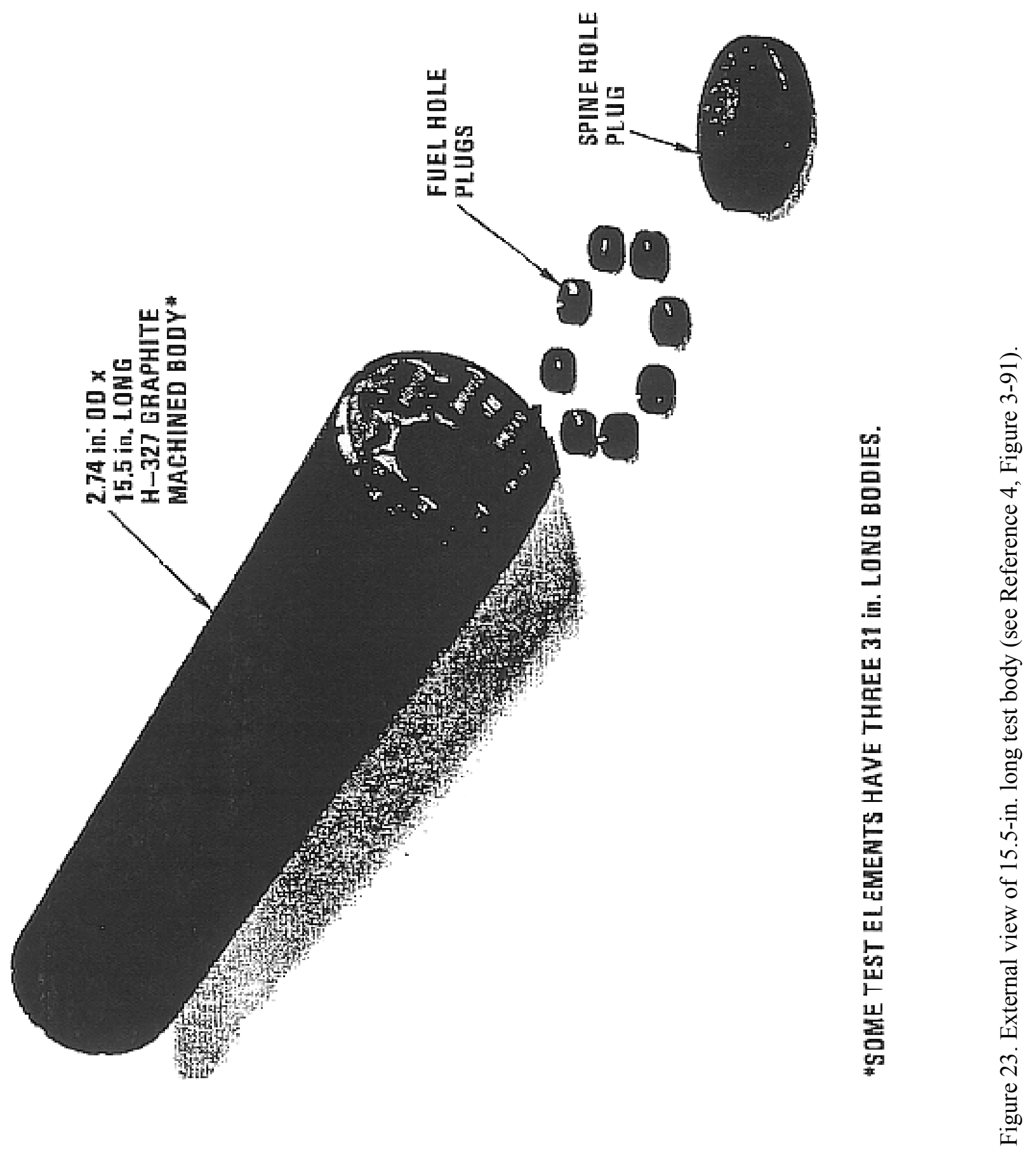



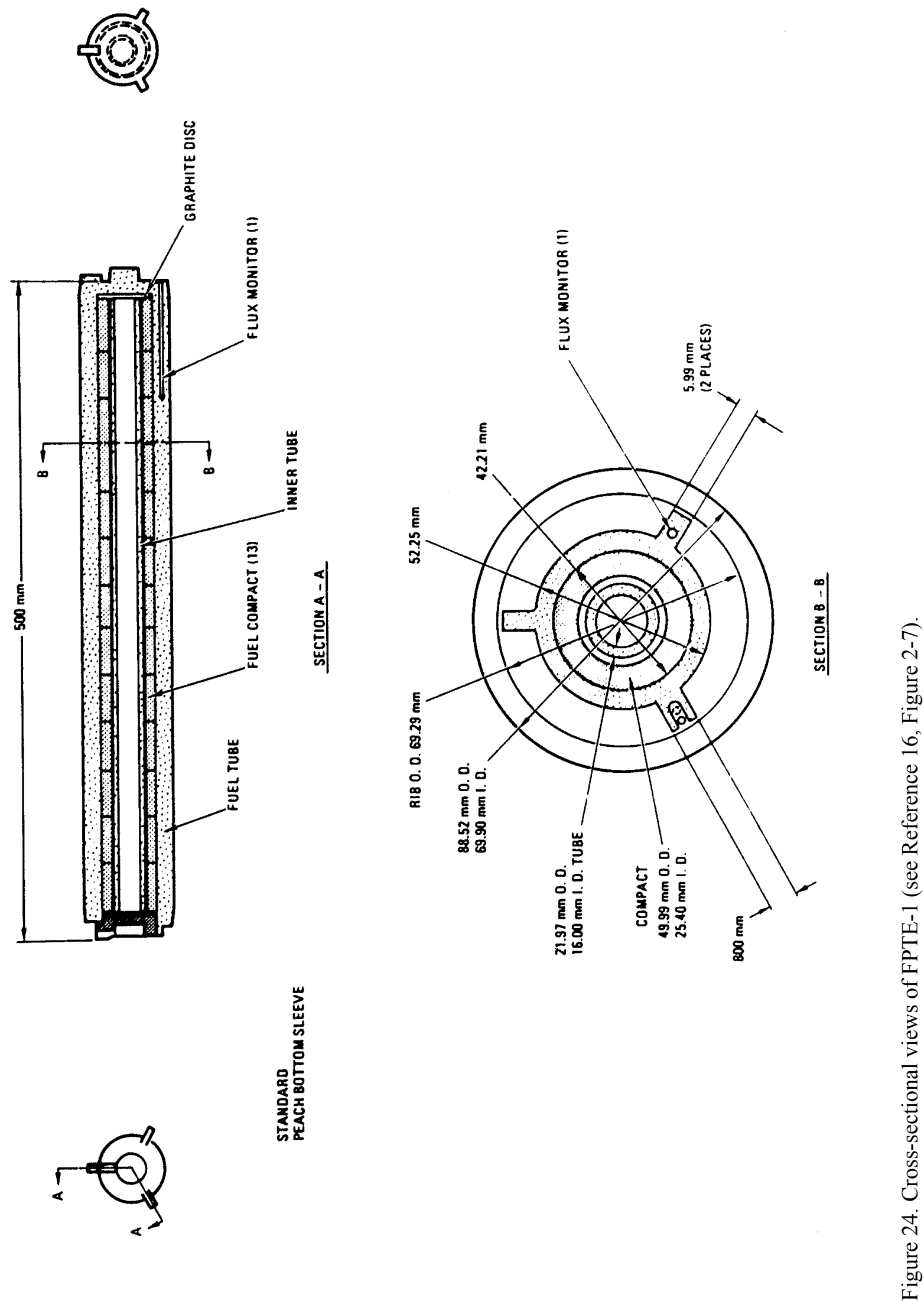


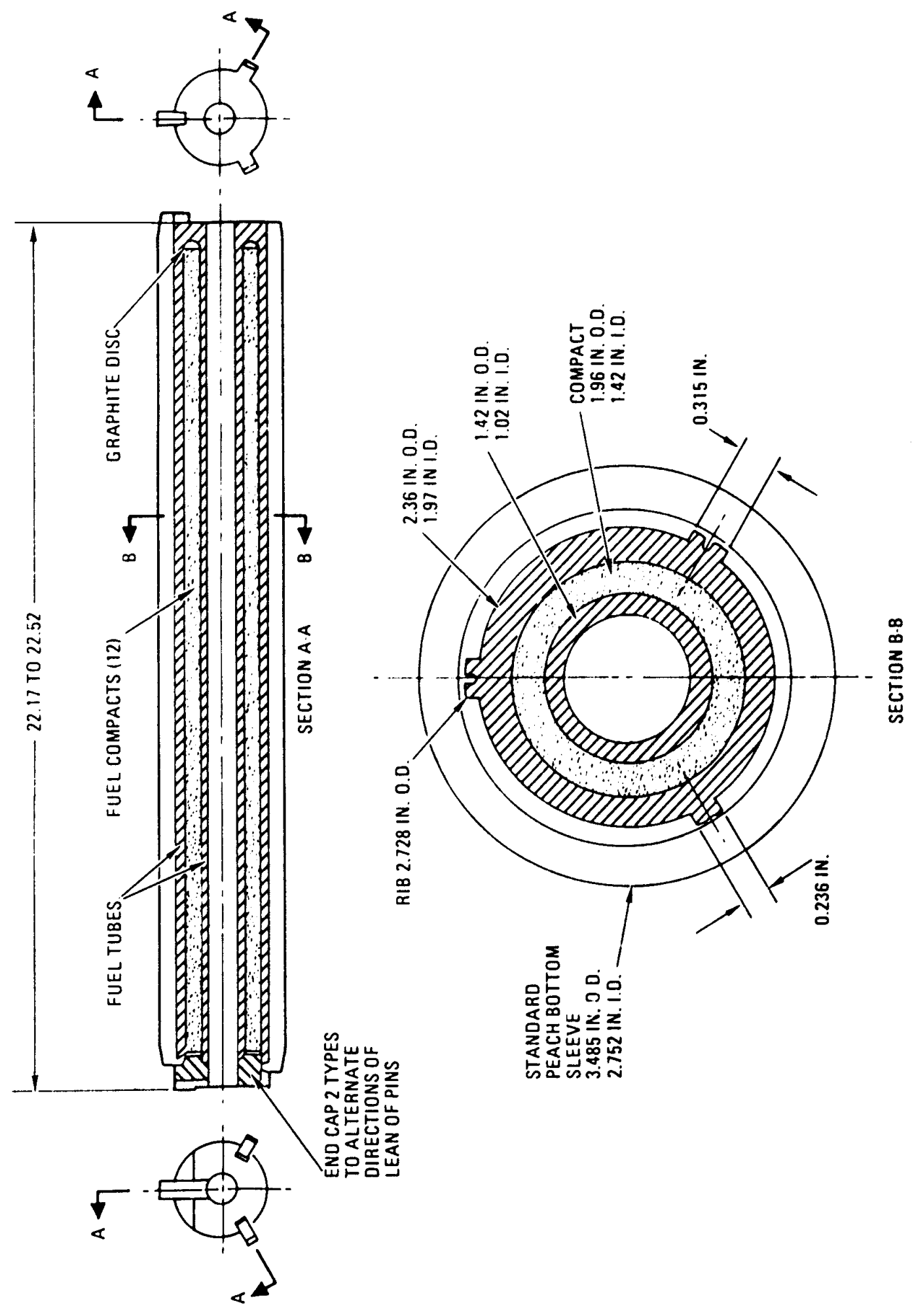

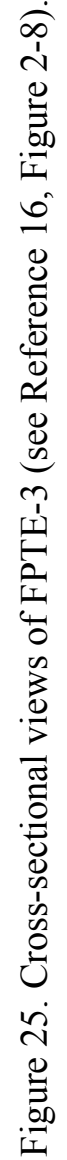


Table 12. Peach Bottom Unit 1 test element fissionable loadings (see Reference 19, Table 5).

\begin{tabular}{|c|c|c|c|c|c|c|c|c|c|c|c|c|c|}
\hline $\mathrm{ID}^{\mathrm{a}}$ & $\begin{array}{l}\% \\
\text { nrichment }\end{array}$ & $\begin{array}{c}{ }^{233} \mathrm{U} \\
(\mathrm{g}) \\
\end{array}$ & $\begin{array}{l}{ }^{235} \mathrm{U} \\
(\mathrm{g}) \\
\end{array}$ & $\begin{array}{l}{ }^{238} \mathrm{U} \\
(\mathrm{g}) \\
\end{array}$ & $\begin{array}{c}\mathrm{U} \\
(\mathrm{g}) \\
\end{array}$ & $\begin{array}{c}{ }^{239} \mathrm{Pu} \\
(\mathrm{g})\end{array}$ & $\begin{array}{c}{ }^{240} \mathrm{Pu} \\
(\mathrm{g})\end{array}$ & $\begin{array}{c}{ }^{241} \mathrm{Pu} \\
(\mathrm{g})\end{array}$ & $\begin{array}{l}\mathrm{Pu} \\
(\mathrm{g})\end{array}$ & $\begin{array}{l}{ }^{232} \mathrm{Th} \\
(\mathrm{g})\end{array}$ & $\mathrm{h} / \mathrm{U}$ & $\begin{array}{l}\text { FEM }^{\mathrm{a}} \\
(\mathrm{g})\end{array}$ & Con \\
\hline PTE-1 & 93.15 & 0.00 & 4.4 & 30.6 & 445.0 & 0.00 & 0.00 & 0.00 & 00 & 1809 & .07 & 1680.7 & \multirow{2}{*}{$\begin{array}{l}\text { At IFSF in position B- } 25 \text { as of } \\
\text { November } 2001 \text {; enveloped by } \\
\text { PTE-2 at BOL }\end{array}$} \\
\hline$(\mathrm{EOL})$ & & 0.00 & 414.4 & 30.6 & 445.0 & 0.00 & 0.00 & 0.00 & 0.00 & 1809 & 4.07 & 1680.7 & \\
\hline-2 & 93.15 & 0.00 & 9.2 & 30.8 & 450.0 & 0.00 & 0.00 & 0.00 & 0.00 & 2153 & 4.78 & 1926.0 & \multirow{2}{*}{$\begin{array}{l}\text { Most }{ }^{235} \mathrm{U} \text {, most } \mathrm{Th} \text {, most FEM; } \\
\text { destroyed in postirradiation } \\
\text { analysis }\end{array}$} \\
\hline$(\mathrm{EOL})$ & & 26.34 & 316.77 & 23.65 & 366.76 & 0.80 & 0.17 & 0.10 & 1.07 & 2120.76 & 5.78 & 1839.6 & \\
\hline BTE-1 & 93.15 & 0.00 & 1.1 & 14.8 & 215.9 & 0.00 & 0.00 & 0.00 & 0 & 64 & 5.85 & 10 & \multirow{2}{*}{$\begin{array}{l}\text { As of November } 2001, \text { Oak } \\
\text { Ridge to send relatively intact } \\
\text { element to INTEC }\end{array}$} \\
\hline$(\mathrm{EOL})$ & & 30.003 & 83.11 & 8.93 & 122.07 & 0.26 & 0.09 & 0.14 & 0.49 & 1211.22 & 9.92 & 973.6 & \\
\hline BTE-2 & 93.15 & 0.00 & 8.9 & 16.1 & 235.0 & 0.00 & 0.00 & 0.00 & 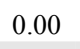 & 567 & 2.41 & 615.5 & \multirow{2}{*}{$\begin{array}{l}\text { Least nonzero Th, least nonzero } \\
\text { Th/U destroyed in postirradiation } \\
\text { analysis; part of Oak Ridge } \\
\text { Canister SNF }\end{array}$} \\
\hline (EOL) & & 16.88 & 87.36 & 9.76 & 114.00 & 0.25 & 0.09 & 0.14 & .48 & 526.21 & 4.62 & 480.0 & \\
\hline BTE-3 & & 0.00 & 0.9 & 13.3 & 194.2 & 0 & 0 & 0 & 0.00 & 762 & 3.92 & 714.4 & \multirow{2}{*}{$\begin{array}{l}\text { As of November 2001, Oak } \\
\text { Ridge to send relatively intact } \\
\text { element to INTEC }\end{array}$} \\
\hline$(\mathrm{EOL})$ & & 19.00 & 67.71 & 8.12 & 94.83 & 0.19 & 0.06 & 0.11 & 0.36 & 727.09 & 7.67 & 603.8 & \\
\hline TE-4 & 1 & 0.00 & 19.6 & 16.1 & 235.7 & 0.00 & 0.00 & 0.00 & 0.00 & 944 & 4.00 & 880.1 & \multirow{2}{*}{$\begin{array}{l}\text { At IFSF in canister and position } \\
\text { L-26 as of November } 2001\end{array}$} \\
\hline$(\mathrm{EOL})$ & & 9.64 & 179.16 & 10.97 & 199.77 & 0.28 & 0.05 & 0.02 & 0.35 & 932.78 & 4.67 & 846.1 & \\
\hline TF-5 & 0315 & 0.00 & 181.1 & 13.3 & 194.4 & 0.00 & 0.00 & 0.00 & 000 & 1518 & 7.81 & 1243.8 & \multirow{2}{*}{$\begin{array}{l}\text { As of November } 2001 \text {, Oak } \\
\text { Ridge to send relatively intact } \\
\text { element to INTEC }\end{array}$} \\
\hline$(\mathrm{EOL})$ & & 32.04 & 65.95 & 7.98 & 105.97 & 0.20 & 0.07 & 0.12 & 0.39 & 1457.91 & 13.76 & 1131.9 & \\
\hline TE-6 & 0 & 0.00 & 168.6 & 12.4 & 181.0 & 0.00 & 0.00 & 0.00 & 0.00 & 1668 & 9.21 & 1336.0 & \multirow{2}{*}{$\begin{array}{l}\text { At IFSF in canister and position } \\
\text { T-27 as of November } 2001\end{array}$} \\
\hline$(\mathrm{EOL})$ & & 14.67 & 131.30 & 8.41 & 154.38 & 0.20 & 0.04 & 0.02 & 0.26 & 1650.59 & 10.69 & 1307.6 & \\
\hline $\mathrm{F}_{1}$ & 93.15 & 0.00 & 2.0 & 14.1 & 20 & 0.00 & 0.00 & 0.00 & 0 & 1538 & 7.46 & 68.4 & \multirow{2}{*}{$\begin{array}{l}\text { Sent to GA for postirradiation } \\
\text { analysis; pieces expected to be } \\
\text { sent to INTEC with } \\
\text { miscellaneous GA SNF }\end{array}$} \\
\hline (EOL) & & 13.40 & 150.84 & 9.58 & 173.82 & 0.23 & 0.05 & 0.02 & 0.30 & 1522.48 & 8.76 & 1235.7 & \\
\hline E-2 & 93 & 00 & 11.8 & 12.6 & 184.4 & 0.00 & 0.00 & .00 & 0.00 & 1640 & 8.89 & 1319.4 & \multirow{2}{*}{$\begin{array}{l}\text { Sent to GA for postirradiation } \\
\text { analysis; pieces expected to be } \\
\text { sent to INTEC with } \\
\text { miscellaneous GA SNF }\end{array}$} \\
\hline$(\mathrm{EOL})$ & & 20.36 & 120.73 & 8.37 & 149.46 & 0.25 & 0.06 & 0.04 & 0.35 & 1614.40 & 10.80 & 1279.8 & \\
\hline$=-5$ & & 00 & 9.4 & 13.9 & 20 & .00 & 0.00 & 0.00 & 0.00 & 108 & 5.32 & 47.1 & \multirow{2}{*}{$\begin{array}{l}\text { Destroyed in postirradiation } \\
\text { analysis; part of Oak Ridge } \\
\text { Canister SNF }\end{array}$} \\
\hline (EOL) & & 23.36 & 72.43 & 8.52 & 104.31 & 0.20 & 0.07 & 0.11 & 0.38 & 1039.43 & 9.96 & 833.2 & \\
\hline E-2 & & 00 & 7.4 & 14.5 & 211.9 & 0.00 & 0.00 & 0.00 & 0.00 & 804 & 3.79 & 760.2 & \multirow{2}{*}{$\begin{array}{l}\text { Sent to GA for postirradiation } \\
\text { analysis; pieces expected to be } \\
\text { sent to INTEC with } \\
\text { miscellaneous GA SNF }\end{array}$} \\
\hline (EOL) & & 19.43 & 98.30 & 9.07 & 126.80 & 27 & 0.09 & .12 & 8 & 773.80 & 6.10 & 667.8 & \\
\hline TE-4 & & 0.00 & 165.2 & 12.2 & 177.4 & 0.00 & 0.00 & 0.00 & 0.00 & 1093 & 6.16 & 930.5 & \multirow{2}{*}{$\begin{array}{l}\text { Destroyed in postirradiation } \\
\text { analysis; part of Oak Ridge } \\
\text { Canister SNF }\end{array}$} \\
\hline$(\mathrm{EOL})$ & & 16.10 & 110.60 & 8.00 & 134.70 & 0.23 & 0.06 & 0.05 & 0.34 & 1072.56 & 7.96 & 884.4 & \\
\hline ГЕ-5 & & 0.00 & 173.8 & 12.8 & 186.6 & 0.00 & 0.00 & 0.00 & 0.00 & 1084 & 5.81 & 932.3 & \multirow{2}{*}{$\begin{array}{l}\text { Destroyed in postirradiation } \\
\text { analysis; part of Oak Ridge } \\
\text { Canister SNF }\end{array}$} \\
\hline$(\mathrm{EOL})$ & & 25.16 & 61.57 & 7.65 & 94.38 & 0.19 & 0.07 & 0.11 & 0.37 & 1022.46 & 10.83 & 813.0 & \\
\hline ГЕ-6 & & 0.00 & 177.5 & 13.1 & 190.6 & 0.00 & 0.00 & 0.00 & & 92 & 4.87 & 827.3 & \multirow{2}{*}{$\begin{array}{l}\text { Destroyed in postirradiation } \\
\text { analysis; might be part of } O a k \\
\text { Ridge Canister SNF }\end{array}$} \\
\hline$(\mathrm{EOL})$ & & 23.66 & 60.31 & 7.78 & 91.75 & 0.19 & 0.07 & 0.12 & 0.38 & 882.06 & 9.61 & 711. & \\
\hline$E-7$ & 15 & 0.00 & 2.8 & 12.7 & 185.5 & 0.00 & 0.00 & 00 & 0 & 1250 & 6.74 & \multirow{2}{*}{\multicolumn{2}{|c|}{$\begin{array}{l}\text { 1047.8 Destroyed in postirradiation } \\
\text { analysis; might be part of Oak } \\
\text { 1018.2 Ridge Canister SNF }\end{array}$}} \\
\hline (EOL) & & 12.78 & 135.34 & 8.60 & 156.72 & 0.22 & 0.04 & 0.02 & 0.28 & 1235.16 & 7.88 & & \\
\hline ГE-8 & 93.15 & 0.00 & 173.0 & 12.7 & 185.7 & 0.00 & 0.00 & 0.00 & 0.00 & 881 & 4.74 & \multirow{2}{*}{\multicolumn{2}{|c|}{$\begin{array}{l}\text { 789.7 Destroyed in postirradiation } \\
\text { analysis; might be part of Oak } \\
677.1 \text { Ridge Canister SNF }\end{array}$}} \\
\hline$(\mathrm{EOL})$ & & 22.51 & 58.99 & 7.58 & 89.08 & 0.19 & 0.06 & 0.11 & 0.36 & 837.34 & 9.40 & & \\
\hline TE-1 & 9.15 & 0.00 & 5.2 & 1342.3 & 1477.5 & 0.00 & 0.00 & 0.00 & 0.00 & 0.00 & 0.00 & \multirow{2}{*}{\multicolumn{2}{|c|}{$\begin{array}{l}135.2 \text { Sent to UKAEA }{ }^{\text {b. not expected }} \\
119.2^{\text {to be returned to USA }}\end{array}$}} \\
\hline$(\mathrm{EOL})$ & & 0.000 & 107.641 & 1330.60 & 1438.24 & 6.65 & 1.18 & 0.58 & 8.41 & 0.00 & 0.00 & & \\
\hline
\end{tabular}


Table 12. (continued).

\begin{tabular}{|c|c|c|c|c|c|c|c|c|c|c|c|c|}
\hline $\mathrm{ID}^{\mathrm{a}}$ & $\begin{array}{c}\% \\
\text { Enrichment }\end{array}$ & $\begin{array}{l}{ }^{233} \mathrm{U} \\
(\mathrm{g})\end{array}$ & $\begin{array}{l}{ }^{235} \mathrm{U} \\
(\mathrm{g})\end{array}$ & $\begin{array}{l}{ }^{238} \mathrm{U} \\
(\mathrm{g})\end{array}$ & $\begin{array}{l}\mathrm{U} \\
(\mathrm{g})\end{array}$ & $\begin{array}{l}{ }^{239} \mathrm{Pu} \\
(\mathrm{g})\end{array}$ & $\begin{array}{c}{ }^{240} \mathrm{Pu} \\
(\mathrm{g})\end{array}$ & $\begin{array}{c}{ }^{241} \mathrm{Pu} \\
(\mathrm{g})\end{array}$ & $\begin{array}{l}\mathrm{Pu} \\
(\mathrm{g})\end{array}$ & $\begin{array}{c}{ }^{232} \mathrm{Th} \\
(\mathrm{g})\end{array}$ & $\mathrm{Th} / \mathrm{U}$ & $\begin{array}{c}\mathrm{FEM}^{\mathrm{a}} \\
(\mathrm{g})\end{array}$ \\
\hline FTE-3 & 93.15 & 0.00 & 191.8 & 14.1 & 205.9 & 0.00 & 0.00 & 0.00 & 0.00 & 997 & 4.84 & 889.6Destroyed in postirradiation \\
\hline (EOL) & & 6.00 & 170.22 & 11.75 & 187.97 & 0.20 & 0.02 & 0.01 & 0.23 & 990.41 & 5.27 & $\begin{array}{l}\text { analysis; part of Oak Ridge } \\
\text { 872.2 Canister SNF, and sample from } \\
\text { GA }\end{array}$ \\
\hline FTE-4 & 93.15 & 0.00 & 175.5 & 12.9 & 188.4 & 0.00 & 0.00 & 0.00 & 0.00 & 1028 & 5.45 & 894.9Destroyed in postirradiation \\
\hline (EOL) & & 15.51 & 107.05 & 10.21 & 132.77 & 0.25 & 0.07 & 0.08 & 0.40 & 1006.65 & 7.58 & $\begin{array}{l}\text { analysis; part of Oak Ridge } \\
\text { 833.9 Canister } S N F \text {, and expected } \\
\text { sample from GA }\end{array}$ \\
\hline FTE-6 & 93.15 & 0.00 & 207.7 & 15.3 & 222.9 & 0.00 & 0.00 & 0.00 & 0.00 & 855 & 3.84 & 806.5 Destroyed in postirradiation \\
\hline$(\mathrm{EOL})$ & & 18.93 & 99.77 & 11.53 & 130.23 & 0.32 & 0.10 & 0.15 & 0.57 & 825.61 & 6.34 & $\begin{array}{l}\text { analysis; part of Oak Ridge } \\
705.0 \text { Canister SNF }\end{array}$ \\
\hline TE-7 & 93.15 & 0.00 & 208.1 & 15.3 & 223.4 & 0.00 & 0.00 & 0.00 & 0.00 & 1396 & 6.25 & 1185.4As of November 2001, Oak \\
\hline (EOL) & & 23.34 & 100.27 & 11.74 & 135.35 & 0.27 & 0.09 & 0.13 & 0.49 & 1359.43 & 10.04 & $\begin{array}{l}\text { Ridge to send relatively intact } \\
1085.2 \text { element to INTEC }\end{array}$ \\
\hline FTE-8 & 93.15 & 0.00 & 169.9 & 12.5 & 182.4 & 0.00 & 0.00 & 0.00 & 0.00 & 519 & 2.85 & 533.3 As of November 2001, Oak \\
\hline (EOL) & & 12.67 & 80.83 & 9.58 & 103.08 & 0.22 & 0.07 & 0.10 & 0.39 & 499.05 & 4.84 & $\begin{array}{l}\text { Ridge to send relatively intact } \\
448.4 \text { element to INTEC }\end{array}$ \\
\hline FTE-9 & 93.15 & 0.00 & 167.4 & 12.3 & 179.8 & 0.00 & 0.00 & 0.00 & 0.00 & 1115 & 6.20 & 947.6 As of Novemb \\
\hline$(\mathrm{EOL})$ & & 22.36 & 83.79 & 9.34 & 115.49 & 0.26 & 0.08 & 0.12 & 0.46 & 1080.01 & 9.35 & $\begin{array}{l}\text { Ridge to send relatively intact } \\
871.7 \text { element to INTEC }\end{array}$ \\
\hline FTE-10 & 93.15 & 0.00 & 160.0 & 11.8 & 171.8 & 0.00 & 0.00 & 0.00 & 0.00 & 685 & 3.99 & $639.6 \mathrm{At}$ \\
\hline$(\mathrm{EOL})$ & & 16.89 & 76.55 & 8.89 & 102.33 & 0.24 & 0.08 & 0.11 & 0.43 & 658.36 & 6.43 & $561.6^{\mathrm{L}-}$ \\
\hline FTE-11 & 93.15 & 0.00 & 208.8 & 15.4 & 224.1 & 0.00 & 0.00 & 0.00 & 0.00 & 891 & 3.98 & 832.5 Destroyed in postirradiation \\
\hline$(\mathrm{EOL})$ & & 19.79 & 93.23 & 11.55 & 124.57 & 0.29 & 0.10 & 0.15 & 0.54 & 858.50 & 6.89 & $\begin{array}{l}\text { is; part of Oak Ridge } \\
\text { er SNF }\end{array}$ \\
\hline FTE-12 & 93.15 & 0.00 & 178.4 & 13.1 & 191.5 & 0.00 & 0.00 & 0.00 & 0.00 & 1339 & 6.99 & 1115.4As of November 2001, Oak \\
\hline$(\mathrm{EOL})$ & & 23.94 & 90.26 & 9.96 & 124.16 & 0.28 & 0.09 & 0.12 & 0.49 & 1301.92 & 10.49 & $\begin{array}{l}\text { send relatively intact } \\
\text { to INTEC }\end{array}$ \\
\hline FPTE-3 & 14.08 & 0.00 & 224.2 & 1368.2 & 1592.4 & 0.00 & 0.00 & 0.00 & 0.00 & 0.00 & 0.00 & 224.2 Sent to UKAEA; not exp \\
\hline (EOL) & & 0.000 & 112.591 & 1337.451 & 1450.04 & 7.15 & 2.36 & 3.05 & 12.56 & 0.00 & 0.00 & $128.9^{\mathrm{be}}$ \\
\hline FTE-13 & 93.15 & 0.00 & 93.1 & 6.8 & 99.9 & NS & NS & NS & 16.7 & 1352 & 13.53 & 1039.5 Most $\mathrm{Pu}$; destroyed in \\
\hline (EOL) & & 23.69 & 50.05 & 4.36 & 78.10 & 1.08 & 2.03 & 1.92 & 5.03 & 1317.24 & 16.87 & $\begin{array}{l}\text { postirradiation analysis; part of } \\
1010.1 \text { Oak Ridge Canister SNF }\end{array}$ \\
\hline FTE-14 & 93.15 & 0.00 & 178.4 & 13.1 & 191.5 & 0.00 & 0.00 & 0.00 & 0.00 & 1923 & 10.04 & 1524.2 Destroyed in $\mathrm{p}$ \\
\hline (EOL) & & 27.83 & 132.15 & 8.69 & 168.67 & 0.23 & 0.05 & 0.03 & 0.31 & 1889.32 & 11.20 & $1494.1_{\text {Can }}^{\text {anal }}$ \\
\hline FTE-15 & 93.15 & 0.00 & 178.7 & 13.1 & 191.9 & 0.00 & 0.00 & 0.00 & 0.00 & 1884 & 9.82 & 1497.3 Destroyed in postirradiation \\
\hline (EOL) & & 34.63 & 104.64 & 8.45 & 147.72 & 0.20 & 0.06 & 0.08 & 0.34 & 1834.43 & 12.42 & $1437.7_{\text {Cani }}^{\text {analy }}$ \\
\hline FTE-16 & 93.15 & 0.00 & 135.0 & 9.9 & 144.9 & 0.00 & 0.00 & 0.00 & 0.00 & 1045 & 7.21 & $d$ in postirradiation \\
\hline (EOL) & & 18.45 & 75.85 & 6.31 & 100.61 & 0.17 & 0.05 & 0.06 & 0.28 & 1018.51 & 10.12 & $\begin{array}{l}\text { analysis; par } \\
815.0 \text { Canister SNI } \\
\end{array}$ \\
\hline FTE-17 & 93.15 & 0.00 & 93.9 & 6.9 & 100.8 & 0.00 & 0.00 & 0.00 & 0.00 & 907 & 9.00 & 728.9 As of November 2001, Oak \\
\hline$(\mathrm{EOL})$ & & 17.70 & 50.00 & 4.37 & 72.07 & 0.11 & 0.04 & 0.05 & 0.20 & 88 & 12.23 & $\begin{array}{l}\text { o send relatively intact } \\
t \text { to INTEC }\end{array}$ \\
\hline FTE-18 & 86.46 & 0.00 & 145.3 & 22.7 & 168.0 & 0.00 & 0.00 & 0.00 & 0.00 & 736 & 4.38 & 660.6 Sent to GA for postirradiation \\
\hline (EOL) & & 15.54 & 75.75 & 14.48 & 105.77 & 0.37 & 0.12 & 0.16 & 0.65 & 712.83 & 6.74 & $\begin{array}{l}\text { analysis; pieces to be sent to } \\
\text { 597.3 INTEC with miscellaneous } G A \\
\text { SNF }\end{array}$ \\
\hline
\end{tabular}

a. Based on shipper safeguards data, test element descriptions, and fuel disposition reports. Unshaded and shaded rows respectively list BOL and EOL information. All Peach Bottom Unit 1 test elements are listed to ensure that models used here in the criticality safety evaluation envelop any relatively intact elements that might eventually be stored or handled at the INEEL and to preserve information used in building this evaluation's models. However, many of these test elements were destroyed during postirradiation analysis, and their remains are not addressed in this evaluation.

b. UKAEA = United Kingdom Atomic Energy Authority. 


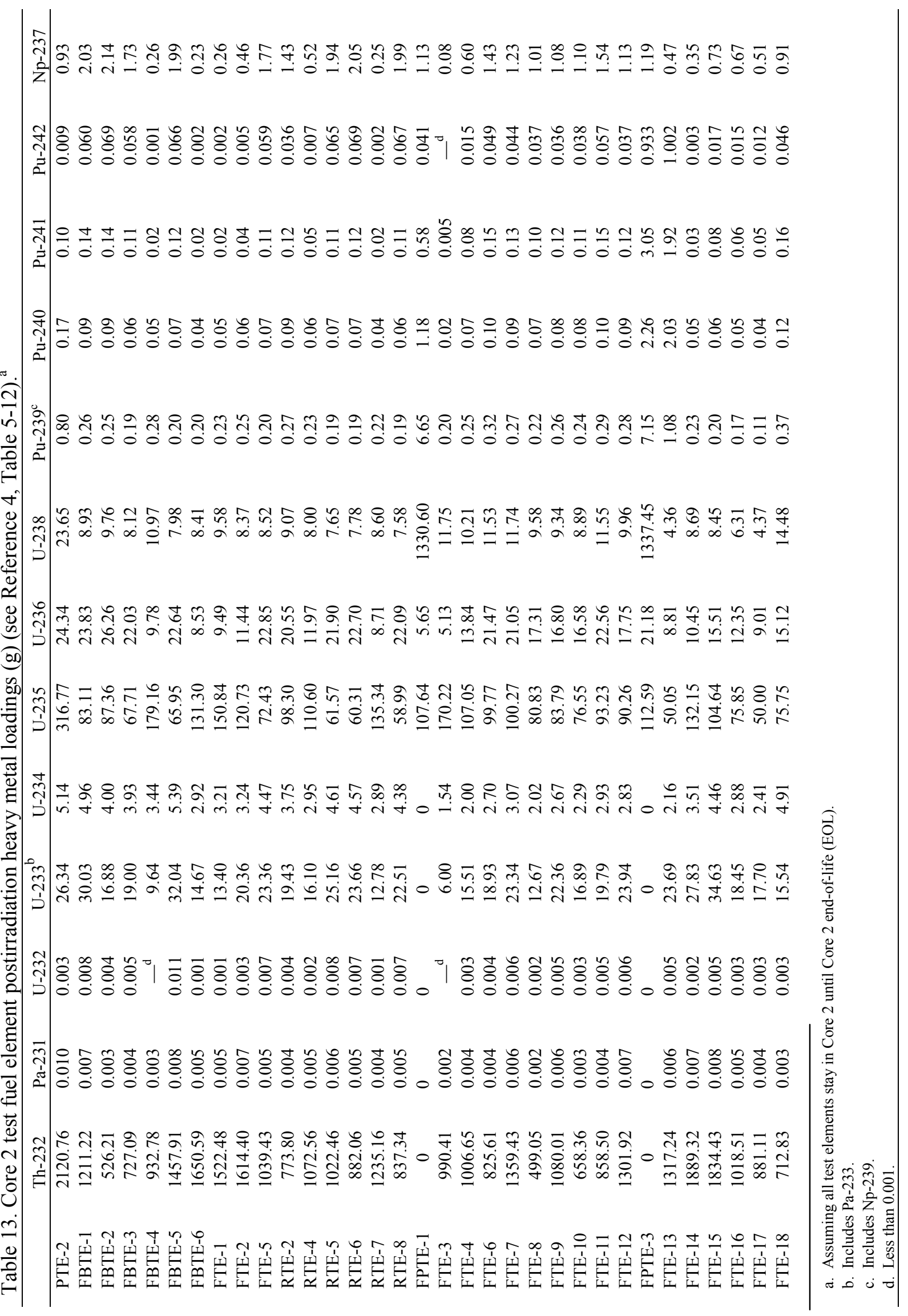




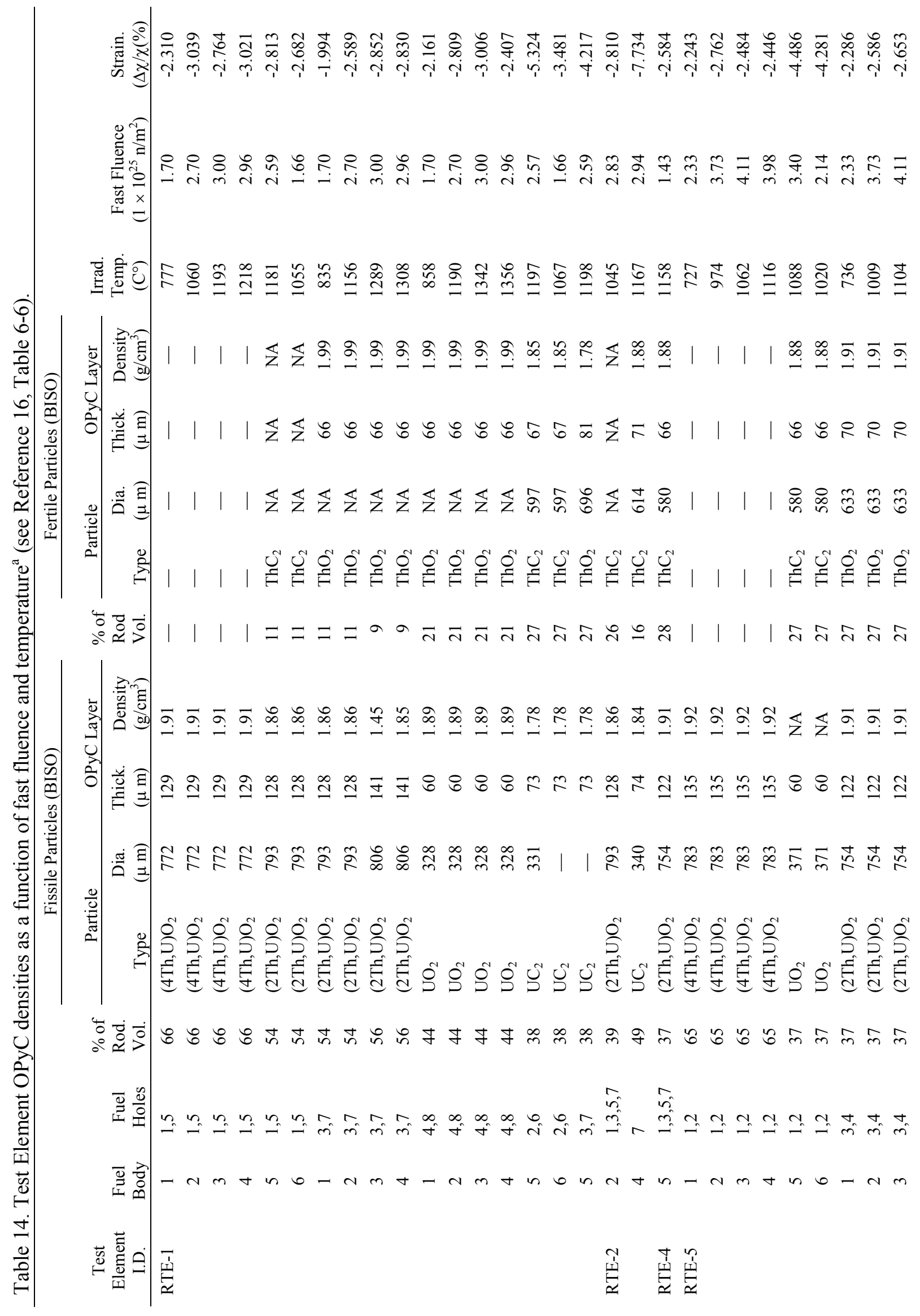




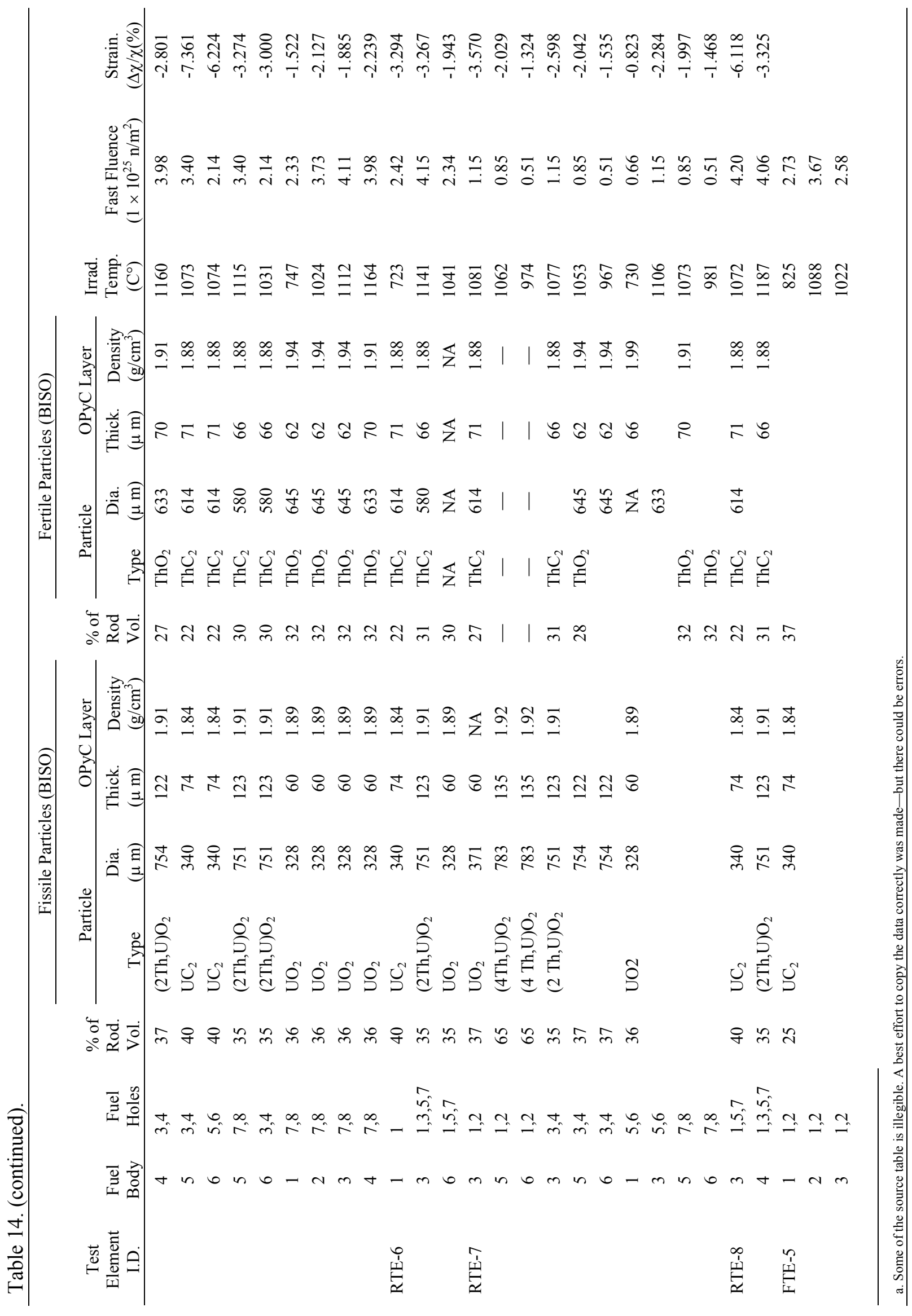




\subsection{Core 2 Description}

The layout for Core 2 is the same as the final layout for Core 1, except that eight of the Type III elements in Core 1 were exchanged for Type II elements for Core 2. Exactly which elements were changed out is not clear. As described earlier, the final Core 1 layout had 84 Type IIIs and 564 Type IIs With the change in Core 2 that is described in Reference 2, the final nominal loading would have been 572 Type II elements and 76 Type III elements. However, there were a large number of test elements irradiated in Core 2, which would change the actual loading numbers. Reference 2 mentions that one side of the reactor contained an additional Type III element (E14-01) that could have caused a flux depression in that area of $4 \%$. This indicates the layout was not symmetrical. No other information regarding the locations of the additional Type II elements was found.

The following nominal core loading information was given in Reference 20:

Thorium $1229 \mathrm{~kg}$

Uranium 235 $177 \mathrm{~kg}$

Rhodium $103 \quad 5 \mathrm{~kg}$

Boron (natural) $\quad 1.54 \mathrm{~kg}$

Note: the Uranium and Thorium loadings in this list are lower than those given for Core 1 in Table 9.

All available information about individual elements from Core 2 is summarized in Appendix B. 


\section{PEACH BOTTOM UNIT 1 OPERATING HISTORY}

The operating history of the Peach Bottom HTGR Cores 1 and 2 is given in Operating History Report for the Peach Bottom HTGR, Volumes 1 and 2 (see References 2 and 21).

The burnup data for the Peach Bottom HTGR Cores 1 and 2 are given in Table 15 (see Reference 4).

Both Peach Bottom HTGR cores (Core 1 and Core 2) were packaged and shipped to the INEEL, UKAEA, ORNL, or GA, with the INEEL receiving the bulk of the fuel.

Calculated source terms for single Core 1 Type II and Core 2 Type II elements are given in Engineering design file (EDF)-3084. ${ }^{22}$ The tables are reproduced here for convenience in Tables 16 and 17. The 90,532 MWd/MTIHM is based on actual Peach Bottom Core 2 operating power history with a conservative assumption related to the number of elements in the core generating power. The total Peach Bottom Core 2 energy production over its operating life is averaged over 702 driver core elements (instead of the 804 total fuel elements in the core). The conservatism assumes that the 102 peripheral elements generated none of the core power.

The source terms given should be viewed with the understanding that the calculations are for average Type II elements, which were not used in the center of the core (Type I elements were in the center). The Type II elements were interspersed with Type III elements containing burnable poison. However, heavy metal data from BOL and EOL indicate that the Type II elements generally had the highest burnup of $\mathrm{U}^{235}$. For Core 2, source documents also indicate the power distribution was not symmetrical over the whole core. Therefore, some individual elements may have a higher source term than the average Type II element.

Information from the operating history regarding individual fuel elements is included, where feasible, in the tables for each core in the appendixes to this fuel summary report.

Table 18 has the results of informal calculations of heat generation. The results were provided by Philip L. Winston and James W. Sterbentz at the INEEL. ${ }^{b}$

Table 15. Burnup data for Peach Bottom Cores 1 and 2 (Reference 4, Table 5.6).

\begin{tabular}{lll}
\hline & \multicolumn{1}{c}{ Core 1 } & \multicolumn{1}{c}{ Core 2 } \\
\hline EFPD & 451.5 & 897.4 \\
MW(t)-h ${ }^{\mathrm{a}}$ & $1,246,089$ & $2,476,454$ \\
Shutdown date & October 3, 1969 & October 31, 1974 \\
Nominal core & & \\
Heavy metal loading & $1,686.14 \mathrm{~kg}$ & $1,418.6 \mathrm{~kg}$ \\
Burnup & $30,795 \mathrm{MWd} / \mathrm{MTHM}$ & $72,717 \mathrm{MWd} / \mathrm{MTHM}$ \\
\hline & & \\
\hline \multirow{2}{*}{ a. Reactor core output 115 MW(t). } & & \\
\hline
\end{tabular}

b. J. W. Sterbentz, INEEL, e-mail to P. L. Winston, INEEL, "Peach Bottom Heat," November 4, 2002. 
Table 16. Isotopic activity concentrations in curies for a single Peach Bottom Unit 1 Core 1 Type II fuel element (see Reference 22, Appendix 2, Table 1).

Information:

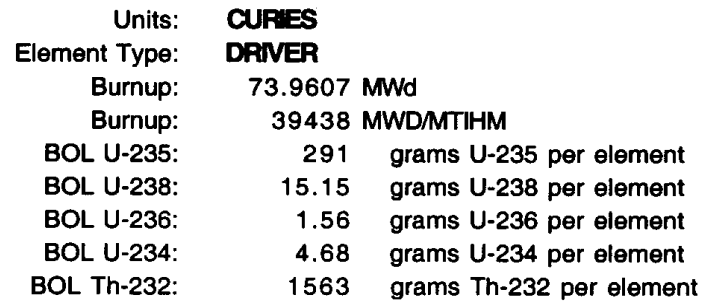

Units: CURES

Element Type: DRIVER

Burnup: $\quad 73.9607$ MWd

Burnup: $\quad 39438$ MWDMTIHM

BOL U-235: $\quad 291$ grams U-235 per element

BOL U-238: $\quad 15.15$ grams U-238 per element

BOL U-236: $\quad 1.56$ grams U-236 per element

BOL U-234: $\quad 4.68$ grams U-234 per element

BOL Th-232: 1563 grams Th-232 per element

Fuel Meat: UC-ThC fuel kernel

Fuel Enrichment: $\quad 93.15$ wt\% U-235

Clad: Graphite

\begin{tabular}{|c|c|c|c|c|c|c|c|c|}
\hline \multirow[b]{2}{*}{ ISOTOPE } & \multicolumn{8}{|c|}{ DECAY DATES } \\
\hline & 1-Jul-96 & 1-Jul-98 & 1-Jul-00 & 1-Jul-02 & 1-Jul-05 & 1-Jul-10 & 1-Jul-15 & 1-Jul-20 \\
\hline H 3 & $7.723 \mathrm{E}-01$ & $6.904 \mathrm{E}-01$ & $6.171 \mathrm{E}-01$ & $5.515 \mathrm{E}-01$ & $4.660 \mathrm{E}-01$ & $3.520 \mathrm{E}-01$ & $2.659 \mathrm{E}-01$ & $2.009 \mathrm{E}-01$ \\
\hline BE 10 & $4.624 \mathrm{E}-05$ & $4.624 \mathrm{E}-05$ & $4.624 \mathrm{E}-05$ & 4.624E-05 & $4.624 \mathrm{E}-05$ & $4.624 \mathrm{E}-05$ & 4.624E-05 & 4.624E-05 \\
\hline C 14 & $2.943 \mathrm{E}-03$ & $2.942 E-03$ & $2.941 \mathrm{E}-03$ & $2.941 \mathrm{E}-03$ & $2.940 \mathrm{E}-03$ & $2.938 \mathrm{E}-03$ & $2.936 \mathrm{E}-03$ & $2.934 \mathrm{E}-03$ \\
\hline CL 36 & $8.320 \mathrm{E}-05$ & $8.320 \mathrm{E}-05$ & $8.320 \mathrm{E}-05$ & $8.320 \mathrm{E}-05$ & $8.320 \mathrm{E}-05$ & $8.320 \mathrm{E}-05$ & $8.320 \mathrm{E}-05$ & $8.320 \mathrm{E}-05$ \\
\hline CR 51 & $0.000 \mathrm{E}+00$ & $0.000 E+00$ & $0.000 \mathrm{E}+00$ & $0.000 E+00$ & $0.000 E+00$ & $0.000 E+00$ & $0.000 \mathrm{E}+00$ & $0.000 E+00$ \\
\hline MN 54 & $4.321 \mathrm{E}-11$ & $8.558 \mathrm{E}-12$ & $1.691 \mathrm{E}-12$ & $3.350 E-13$ & $2.946 \mathrm{E}-14$ & $5.132 \mathrm{E}-16$ & $8.939 \mathrm{E}-18$ & $1.554 \mathrm{E}-19$ \\
\hline FE 55 & $4.972 E-04$ & $2.918 \mathrm{E}-04$ & $1.712 \mathrm{E}-04$ & $1.005 \mathrm{E}-04$ & $4.514 \mathrm{E}-05$ & $1.191 \mathrm{E}-05$ & $3.140 \mathrm{E}-06$ & $8.275 \mathrm{E}-07$ \\
\hline FE 59 & $2.109 \mathrm{E}-67$ & & & $4.648 \mathrm{E}-82$ & $2.165 \mathrm{E}-89$ & $0.000 E+00$ & $0.000 E+00$ & $0.000 E+00$ \\
\hline CO 60 & $1.710 \mathrm{E}-01$ & $1.315 \mathrm{E} \cdot 01$ & $1.011 \mathrm{E}-01$ & $7.769 \mathrm{E}-02$ & $5.236 \mathrm{E}-02$ & $2.713 \mathrm{E}-02$ & $1.405 \mathrm{E}-02$ & $7.279 \mathrm{E}-03$ \\
\hline NI 59 & $1.141 \mathrm{E}-04$ & $1.141 \mathrm{E}-04$ & $1.141 \mathrm{E}-04$ & $1.141 \mathrm{E}-04$ & $1.141 \mathrm{E}-04$ & $1.141 \mathrm{E}-04$ & $1.141 \mathrm{E}-04$ & $1.141 \mathrm{E}-04$ \\
\hline NI 63 & $1.182 \mathrm{E}-02$ & $1.164 \mathrm{E}-02$ & $1.147 \mathrm{E}-02$ & $1.129 \mathrm{E}-02$ & $1.104 \mathrm{E}-02$ & $1.063 \mathrm{E}-02$ & $1.024 \mathrm{E}-02$ & $9.862 \mathrm{E}-03$ \\
\hline ZN 65 & $4.860 \mathrm{E}-14$ & $6.103 \mathrm{E}-15$ & $7.641 \mathrm{E}-16$ & $9.595 \mathrm{E}-17$ & $4.257 \mathrm{E}-18$ & $2.372 E-20$ & $1.321 \mathrm{E}-22$ & $7.341 E-25$ \\
\hline SE 79 & $1.054 \mathrm{E}-03$ & 03 & 1.05 & -03 & $1.054 \mathrm{E}-03$ & $1.054 \mathrm{E}-03$ & $1.054 \mathrm{E}-03$ & $1.054 \mathrm{E}-03$ \\
\hline KA 85 & $5.096 \mathrm{E}+00$ & $4.479 \mathrm{E}+00$ & $3.935 \mathrm{E}+00$ & $3.458 \mathrm{E}+00$ & $2.848 \mathrm{E}+00$ & $2.061 \mathrm{E}+00$ & $1.492 E+00$ & $1.080 \mathrm{E}+00$ \\
\hline RB 87 & $6.745 \mathrm{E}-08$ & $6.745 \mathrm{E}-08$ & $6.745 E-08$ & $6.745 \mathrm{E}-08$ & $6.745 \mathrm{E}-08$ & $6.745 \mathrm{E}-08$ & $6.745 \mathrm{E}-08$ & $6.745 E-08$ \\
\hline SR 89 & 2.427E-55 & $1.080 \mathrm{E}-59$ & $4.740 \mathrm{E}-64$ & $2.109 \mathrm{E}-68$ & $6.173 E-75$ & $8.039 \mathrm{E}-86$ & $1.047 \mathrm{E}-96$ & $0.000 \mathrm{E}+00$ \\
\hline SR 90 & $1.196 \mathrm{E}+02$ & $1.140 E+02$ & $1.087 E+02$ & $1.037 \mathrm{E}+02$ & $9.652 E+01$ & $8.569 \mathrm{E}+01$ & $7.607 E+01$ & $6.754 \mathrm{E}+01$ \\
\hline Y 90 & $1.196 \mathrm{E}+02$ & $1.140 \mathrm{E}+02$ & $1.087 E+02$ & $1.037 \mathrm{E}+02$ & $9.654 \mathrm{E}+01$ & $8.571 E+01$ & $7.609 E+01$ & $6.755 \mathrm{E}+01$ \\
\hline Y 91 & $2.719 \mathrm{E}-47$ & $4.770 \mathrm{E}-51$ & $8.267 E-55$ & $E-58$ & $3.328 \mathrm{E}-64$ & 1.3 & $E-83$ & $6 \mathrm{E}-92$ \\
\hline ZR 93 & 4.95 & -03 & 4.95 & & $4.953 \mathrm{E}-03$ & 4.953E-03 & $4.953 \mathrm{E}-03$ & $4.953 \mathrm{E}-03$ \\
\hline ZR 95 & $5.829 E-43$ & $2.143 \mathrm{E}-46$ & $7.792 \mathrm{E}-50$ & $2.864 \mathrm{E}-53$ & $1.997 \mathrm{E}-58$ & $5.119 \mathrm{E}-67$ & $1.312 \mathrm{E}-75$ & $3.326 \mathrm{E}-84$ \\
\hline NB 93M & 3.573 & -03 & & & $3.990 \mathrm{E}-03$ & & & $4.372 \mathrm{E}-03$ \\
\hline NB 94 & $3.853 \mathrm{E}-05$ & $3.852 E-05$ & $3.852 \mathrm{E}-05$ & $3.852 E-05$ & $3.852 E-05$ & 3.851 E-05 & $3.850 \mathrm{E}-05$ & $3.850 \mathrm{E}-05$ \\
\hline NB 95 & $1.339 \mathrm{E}-42$ & $4.758 \mathrm{E}-46$ & 1.73 & -53 & $4.434 \mathrm{E}-58$ & 1.13 & -75 & $E-84$ \\
\hline NB 95M & 4.324 & $1.590 \mathrm{E}-48$ & $5.781 \mathrm{E}-52$ & $2.125 \mathrm{E}-55$ & $1.482 \mathrm{E}-60$ & 3.79 & E-78 & $2.468 \mathrm{E} \cdot 86$ \\
\hline MO 93 & $1.256 \mathrm{E}-06$ & $1.255 \mathrm{E}-06$ & $1.255 \mathrm{E}-06$ & $1.254 \mathrm{E}-06$ & $1.254 \mathrm{E}-06$ & $1.252 \mathrm{E}-06$ & $E-06$ & $1.250 \mathrm{E}-06$ \\
\hline TC 99 & .02 & -02 & & & $3.116 \mathrm{E}-02$ & 3.1 & -02 & -02 \\
\hline RU103 & $1.736 \mathrm{E}-69$ & \begin{tabular}{|c|}
$4.418 E-75$ \\
\end{tabular} & -80 & -86 & $1.123 \mathrm{E}-94$ & 0.00 & +00 & $E+00$ \\
\hline RU106 & $2.602 \mathrm{E}-06$ & $6.583 E-07$ & 1.66 & & -09 & 1.7 & -12 & E-13 \\
\hline RH103M & $1.563 \mathrm{E}-69$ & $3.983 E-75$ & 9.96 & -86 & $1.012 E-94$ & 0.00 & $0.000 E+00$ & $0.000 \mathrm{E}+00$ \\
\hline RH106 & $2.602 E-06$ & & & .08 & -09 & 1.71 & $E-12$ & $1.770 \mathrm{E}-13$ \\
\hline PD107 & 3.70 & 3.70 & & & $3.702 \mathrm{E}-05$ & 3.70 & $E-05$ & $3.702 E-05$ \\
\hline AG110 & $1.782 E-14$ & $2.352 \mathrm{E}-15$ & $3.096 \mathrm{E}-16$ & 4.088 & $1.955 \mathrm{E}-18$ & 1.2 & & $\mathrm{E}-25$ \\
\hline AG110 & & & $2.328 \mathrm{E}-14$ & 3.074 & $1.469 \mathrm{E}-16$ & 9.2 & -21 & E-23 \\
\hline AG111 & $0.000 E+00$ & $0.000 \mathrm{E}+00$ & +00 & 0.00 & $0.000 E+00$ & $0.000 \mathrm{E}+00$ & +00 & $0.000 E+00$ \\
\hline CD113M & 8.20 & 7.4 & & & & & & \\
\hline & 0.000 & 0.00 & & 0.0 & 0.00 & $0.000 E+00$ & $0.000 \mathrm{E}+00$ & $0.000 \mathrm{E}+00$ \\
\hline CD115M & $1.471 \mathrm{E}-66$ & 1.73 & 2.02 & $2.386 E-81$ & $9.536 \mathrm{E}-89$ & $0.000 E+00$ & $0.000 \mathrm{E}+00$ & $0.000 E+00$ \\
\hline IN114 & $5.603 E-61$ & $2.043 \mathrm{E}-65$ & $345 \mathrm{E}-70$ & $2.678 \mathrm{E}-74$ & $5.813 \mathrm{E}-81$ & $4.601 \mathrm{E}-92$ & $0.000 \mathrm{E}+00$ & $0.000 \mathrm{E}+00$ \\
\hline
\end{tabular}


Table 16. (continued).

\begin{tabular}{|c|c|c|c|c|c|c|c|c|}
\hline IN114M & $5.855 \mathrm{E}-61$ & $2.135 \mathrm{E}-65$ & $7.674 \mathrm{E}-70$ & $2.799 \mathrm{E}-74$ & $6.074 \mathrm{E}-81$ & $4.808 \mathrm{E}-92$ & $0.000 \mathrm{E}+00$ & $0.000 E+00$ \\
\hline IN115M & $1.029 \mathrm{E}-70$ & $1.215 \mathrm{E}-75$ & $1.412 E-80$ & $1.668 \mathrm{E}-85$ & $6.666 \mathrm{E}-93$ & $0.000 E+00$ & $0.000 \mathrm{E}+00$ & $0.000 \mathrm{E}+00$ \\
\hline SN119M & $1.999 \mathrm{E}-13$ & $\begin{array}{l}2.535 \mathrm{E}-14 \\
\end{array}$ & $3.206 \mathrm{E}-15$ & $4.066 \mathrm{E}-16$ & $1.830 \mathrm{E}-17$ & $1.045 \mathrm{E}-19$ & $5.968 \mathrm{E}-22$ & $3.398 \mathrm{E}-24$ \\
\hline SN121M & $1.771 \mathrm{E}-04$ & $1.723 \mathrm{E}-04$ & $1.675 \mathrm{E}-04$ & $1.630 \mathrm{E}-04$ & $1.563 \mathrm{E}-04$ & $1.459 \mathrm{E}-04$ & $1.361 \mathrm{E}-04$ & $1.269 \mathrm{E}-04$ \\
\hline SN123 & $8.093 \mathrm{E}-23$ & $1.609 \mathrm{E}-24$ & $3.186 \mathrm{E}-26$ & 6.337E-28 & $1.768 \mathrm{E}-30$ & $9.816 \mathrm{E}-35$ & $5.449 \mathrm{E}-39$ & $3.009 \mathrm{E}-43$ \\
\hline SN125 & $0.000 \mathrm{E}+00$ & $0.000 \mathrm{E}+00$ & $0.000 \mathrm{E}+00$ & $0.000 E+00$ & $0.000 \mathrm{E}+00$ & $0.000 E+00$ & $0.000 E+00$ & $0.000 E+00$ \\
\hline SN126 & $9.798 \mathrm{E}-04$ & $9.798 \mathrm{E}-04$ & $9.798 \mathrm{E}-04$ & $9.798 \mathrm{E}-04$ & $9.797 \mathrm{E}-04$ & $9.797 \mathrm{E}-04$ & $9.797 \mathrm{E}-04$ & $9.796 \mathrm{E}-04$ \\
\hline SB124 & $2.883 \mathrm{E}-49$ & $6.446 \mathrm{E}-53$ & $1.425 \mathrm{E}-56$ & $3.186 \mathrm{E}-60$ & $1.053 \mathrm{E}-65$ & $7.779 \mathrm{E}-75$ & $5.748 \mathrm{E}-84$ & $4.200 \mathrm{E}-93$ \\
\hline SB125 & $1.838 \mathrm{E}-02$ & $1.114 \mathrm{E}-02$ & $6.755 \mathrm{E}-03$ & 4.097E-03 & $1.933 \mathrm{E}-03$ & $5.533 \mathrm{E}-04$ & $1.584 \mathrm{E}-04$ & 4.529E-05 \\
\hline SB126 & $1.372 \mathrm{E}-04$ & $1.372 E-04$ & $1.372 \mathrm{E}-04$ & 1.372E-04 & $1.372 \mathrm{E}-04$ & $1.372 \mathrm{E}-04$ & $1.372 E-04$ & $1.372 E-04$ \\
\hline SB126M & $9.798 \mathrm{E}-04$ & $9.798 \mathrm{E}-04$ & $9.798 \mathrm{E}-04$ & $9.798 \mathrm{E}-04$ & $9.797 \mathrm{E}-04$ & $9.797 \mathrm{E}-04$ & $9.797 \mathrm{E}-04$ & $9.796 \mathrm{E}-04$ \\
\hline TE123M & $2.908 \mathrm{E}-27$ & $4.240 \mathrm{E}-29$ & $6.146 \mathrm{E}-31$ & $8.961 \mathrm{E}-33$ & $1.568 \mathrm{E}-35$ & $4.004 \mathrm{E}-40$ & $1.022 \mathrm{E}-44$ & $2.592 \mathrm{E}-49$ \\
\hline TE125M & $4.484 \mathrm{E}-03$ & $2.720 \mathrm{E}-03$ & $1.649 \mathrm{E}-03$ & $9.997 \mathrm{E}-04$ & $4.717 \mathrm{E}-04$ & $1.350 \mathrm{E}-04$ & $3.863 \mathrm{E}-05$ & $1.105 \mathrm{E}-05$ \\
\hline TE127 & $2.579 \mathrm{E}-26$ & $2.485 \mathrm{E}-28$ & $2.380 \mathrm{E}-30$ & $2.294 \mathrm{E}-32$ & $2.157 \mathrm{E}-35$ & $1.955 \mathrm{E}-40$ & $1.772 E-45$ & $1.596 \mathrm{E}-50$ \\
\hline TE127M & $2.633 \mathrm{E}-26$ & $2.537 \mathrm{E}-28$ & $2.430 \mathrm{E}-30$ & $2.342 \mathrm{E}-32$ & $2.203 \mathrm{E}-35$ & $1.996 \mathrm{E}-40$ & $1.809 \mathrm{E}-45$ & $1.629 \mathrm{E}-50$ \\
\hline TE129 & $2.088 \mathrm{E}-86$ & $6.019 \mathrm{E}-93$ & $1.699 \mathrm{E}-99$ & $0.000 \mathrm{E}+00$ & $0.000 \mathrm{E}+00$ & $0.000 \mathrm{E}+00$ & $0.000 \mathrm{E}+00$ & $0.000 \mathrm{E}+00$ \\
\hline TE129M & $3.208 \mathrm{E}-86$ & $9.246 \mathrm{E}-93$ & $2.610 \mathrm{E}-99$ & $0.000 \mathrm{E}+00$ & $0.000 E+00$ & $0.000 \mathrm{E}+00$ & $0.000 E+00$ & $0.000 \mathrm{E}+00$ \\
\hline 1129 & $5.714 \mathrm{E}-05$ & $5.714 \mathrm{E}-05$ & $5.714 \mathrm{E}-05$ & $5.714 \mathrm{E}-05$ & $5.714 \mathrm{E}-05$ & $5.714 \mathrm{E}-05$ & $5.714 \mathrm{E}-05$ & 5.714E-05 \\
\hline $\mid 131$ & $0.000 E+00$ & $0.000 E+00$ & $0.000 E+00$ & $0.000 \mathrm{E}+00$ & $0.000 E+00$ & $0.000 E+00$ & $0.000 E+00$ & $0.000 \mathrm{E}+00$ \\
\hline XE131M & $0.000 E+00$ & $0.000 E+00$ & $0.000 \mathrm{E}+00$ & $0.000 E+00$ & $0.000 E+00$ & $0.000 \mathrm{E}+00$ & $0.000 \mathrm{E}+00$ & $0.000 \mathrm{E}+00$ \\
\hline XE133 & $0.000 E+00$ & $0.000 E+00$ & $0.000 E+00$ & $0.000 E+00$ & $0.000 \mathrm{E}+00$ & $0.000 E+00$ & $E+00$ & $E+00$ \\
\hline CS134 & $2.265 \mathrm{E}-02$ & $1.157 \mathrm{E}-02$ & $5.905 \mathrm{E}-03$ & $3.015 \mathrm{E}-03$ & $1.099 \mathrm{E}-03$ & $2.049 \mathrm{E}-04$ & $3.815 \mathrm{E}-05$ & $7.101 \mathrm{E}-06$ \\
\hline CS135 & $1.922 \mathrm{E}-03$ & $1.922 \mathrm{E}-03$ & $1.922 \mathrm{E}-03$ & -03 & $E-03$ & E-03 & $E-03$ & $1.922 \mathrm{E}-03$ \\
\hline CS136 & $0.000 \mathrm{E}+00$ & $0.000 E+00$ & $0.000 \mathrm{E}+00$ & $0.000 E+00$ & $0.000 E+00$ & $0.000 \mathrm{E}+00$ & $0.000 E+00$ & $0.000 E+00$ \\
\hline CS137 & $1.263 \mathrm{E}+02$ & $1.206 \mathrm{E}+02$ & $1.152 \mathrm{E}+02$ & $1.100 \mathrm{E}+02$ & $1.026 \mathrm{E}+02$ & $9.140 E+01$ & $8.143 E+01$ & $7.254 \mathrm{E}+01$ \\
\hline BA136M & $0.000 \mathrm{E}+00$ & $0.000 E+00$ & $0.000 \mathrm{E}+00$ & $0.000 \mathrm{E}+00$ & $0.000 E+00$ & $0.000 E+00$ & $0.000 E+00$ & $0.000 \mathrm{E}+00$ \\
\hline BA137M & $E+02$ & $1.141 \mathrm{E}+02$ & $1.089 \mathrm{E}+02$ & $1.040 \mathrm{E}+02$ & $9.706 \mathrm{E}+01$ & $8.647 \mathrm{E}+01$ & $7.703 E+01$ & $6.863 E+01$ \\
\hline BA140 & $0.000 \mathrm{E}+00$ & $0.000 \mathrm{E}+00$ & $0.000 \mathrm{E}+00$ & $0.000 E+00$ & $0.000 E+00$ & $0.000 E+00$ & $0.000 E+00$ & $0.000 \mathrm{E}+00$ \\
\hline LA140 & $0.000 \mathrm{E}+00$ & $0.000 E+00$ & $0.000 \mathrm{E}+00$ & $0.000 \mathrm{E}+00$ & $0.000 \mathrm{E}+00$ & +00 & $0.000 E+00$ & $0.000 E+00$ \\
\hline CE141 & $1.782 \mathrm{E}-87$ & $3.102 E-94$ & $0.000 E+00$ & $0.000 E+00$ & $0.000 E+00$ & & $0.000 E+00$ & $0.000 E+00$ \\
\hline CE142 & $6.635 \mathrm{E}-08$ & $6.635 \mathrm{E}-08$ & $6.635 \mathrm{E}-08$ & $6.635 \mathrm{E}-08$ & $6.635 \mathrm{E}-08$ & -08 & $6.635 \mathrm{E}-08$ & 5E-08 \\
\hline CE144 & $1.547 \mathrm{E}-07$ & $2.608 \mathrm{E}-08$ & 4.387E-09 & $7.398 \mathrm{E}-10$ & & -13 & E-15 & $8.057 \mathrm{E}-17$ \\
\hline PR143 & $0.000 E+00$ & $0.000 E+00$ & $0.000 E+00$ & $0.000 \mathrm{E}+00$ & $0.000 E+00$ & +00 & $E+00$ & $0.000 \mathrm{E}+00$ \\
\hline PR144 & $1.547 \mathrm{E}-07$ & $2.608 \mathrm{E}-08$ & $4.387 \mathrm{E}-09$ & $7.398 \mathrm{E}-10$ & -11 & -13 & EE-15 & $8.058 \mathrm{E}-17$ \\
\hline PR144M & $1.856 \mathrm{E}-09$ & $3.130 \mathrm{E}-10$ & $5.265 \mathrm{E}-11$ & $8.877 \mathrm{E}-12$ & $E-13$ & $E-15$ & $E-17$ & $E-19$ \\
\hline ND144 & $3.274 \mathrm{E}-12$ & $3.274 \mathrm{E}-12$ & $3.274 \mathrm{E}-12$ & $3.274 \mathrm{E}-12$ & $3.274 \mathrm{E}-12$ & $3.274 \mathrm{E}-12$ & $3.274 \mathrm{E}-12$ & $3.274 \mathrm{E}-12$ \\
\hline ND147 & $0.000 E+00$ & $0.000 E+00$ & $0.000 \mathrm{E}+00$ & $0.000 E+00$ & $E+00$ & +00 & $E+00$ & $0.000 \mathrm{E}+00$ \\
\hline PM145 & 1.607E-05 & $1.486 \mathrm{E}-05$ & $1.374 \mathrm{E}-05$ & $1.271 \mathrm{E}-05$ & $1.130 \mathrm{E}-05$ & $9.288 \mathrm{E}-06$ & $7.637 \mathrm{E}-06$ & $6.278 E-06$ \\
\hline PM147 & $4.459 \mathrm{E}-01$ & $2.630 \mathrm{E}-01$ & $1.550 \mathrm{E}-01$ & $9.140 \mathrm{E}-02$ & -02 & -02 & $2.947 \mathrm{E}-03$ & $7.859 \mathrm{E}-04$ \\
\hline PM148M & $2.376 \mathrm{E}-69$ & $1.133 \mathrm{E}-74$ & $5.318 \mathrm{E}-80$ & $2.538 E-85$ & $2.601 \mathrm{E}-93$ & $0.000 E+00$ & $E+00$ & $0.000 E+00$ \\
\hline PM148 & $1.210 \mathrm{E}-70$ & $6.385 \mathrm{E}-76$ & $2.995 \mathrm{E}-81$ & $E-86$ & -94 & $0.000 \mathrm{E}+00$ & +00 & $0.000 \mathrm{E}+00$ \\
\hline SM145 & $9.503 \mathrm{E}-13$ & $2.146 \mathrm{E}-13$ & $4.836 \mathrm{E}-14$ & $1.092 \mathrm{E}-14$ & $1.170 \mathrm{E}-15$ & -17 & $E-19$ & $1.651 \mathrm{E}-20$ \\
\hline SM147 & 1.73 & $1.731 \mathrm{E}-08$ & 1.73 & $E-08$ & -08 & $1.732 \mathrm{E}-08$ & $1.732 \mathrm{E}-08$ & $1.732 \mathrm{E}-08$ \\
\hline SM151 & $1.802 E+00$ & $1.775 E+00$ & $1.747 E+00$ & +00 & 1.68 & $1.618 \mathrm{E}+00$ & $1.557 \mathrm{E}+00$ & $1.498 E+00$ \\
\hline EU152 & 3.58 & $3.239 \mathrm{E}-02$ & $2.925 \mathrm{E}-02$ & $2.642 \mathrm{E}-02$ & 2.26 & $1.758 \mathrm{E}-02$ & $1.362 \mathrm{E}-02$ & $1.056 \mathrm{E}-02$ \\
\hline EU154 & $7.205 \mathrm{E}-01$ & $6.134 \mathrm{E}-01$ & $5.220 \mathrm{E}-01$ & $4.443 E-01$ & 3.48 & $2.332 \mathrm{E}-01$ & $1.559 \mathrm{E}-01$ & $1.041 \mathrm{E}-01$ \\
\hline EU155 & 1.22 & $9.234 \mathrm{E}-02$ & $6.981 \mathrm{E}-02$ & $5.279 \mathrm{E}-02$ & $3.471 \mathrm{E}-02$ & $1.725 \mathrm{E}-02$ & $8.581 \mathrm{E}-03$ & $4.264 \mathrm{E}-03$ \\
\hline EU156 & $0.000 E+00$ & $0.000 E+00$ & $0.000 \mathrm{E}+00$ & $0.000 E+00$ & $0.000 E+00$ & $0.000 \mathrm{E}+00$ & $0.000 \mathrm{E}+00$ & $0.000 \mathrm{E}+00$ \\
\hline GD153 & $2.213 \mathrm{E}-13$ & $2.735 \mathrm{E}-14$ & $3.371 \mathrm{E}-15$ & $4.165 \mathrm{E}-16$ & $1.805 \mathrm{E}-17$ & $9.664 \mathrm{E}-20$ & $5.174 \mathrm{E}-22$ & $2.762 \mathrm{E}-24$ \\
\hline TB160 & $3.832 \mathrm{E}-41$ & $3.501 \mathrm{E}-44$ & $3.167 \mathrm{E}-47$ & $2.893 \mathrm{E}-50$ & $7.910 \mathrm{E}-55$ & & $4.936 \mathrm{E}-70$ & $1.222 \mathrm{E}-77$ \\
\hline TL206 & $5.012 \mathrm{E}-10$ & $5.012 \mathrm{E}-10$ & $5.012 \mathrm{E}-10$ & $5.012 \mathrm{E}-10$ & $5.012 E-10$ & $5.012 E-10$ & $5.012 \mathrm{E}-10$ & $5.012 E-10$ \\
\hline TL207 & E-04 & $2.247 \mathrm{E}-04$ & $2.334 \mathrm{E}-04$ & $2.416 \mathrm{E}-04$ & $2.530 \mathrm{E}-04$ & & $2.838 \mathrm{E}-04$ & $2.960 \mathrm{E}-04$ \\
\hline TL208 & $1.121 \mathrm{E}-02$ & $1.099 \mathrm{E}-02$ & $1.078 \mathrm{E}-02$ & $1.058 \mathrm{E}-02$ & $1.027 \mathrm{E}-02$ & $9.781 \mathrm{E} \cdot 03$ & $9.325 \mathrm{E} \cdot 03$ & $8.889 \mathrm{E}-03$ \\
\hline PB210 & -08 & 2.19 & $2.540 \mathrm{E}-08$ & $2.915 \mathrm{E}-08$ & $3.543 \mathrm{E}-08$ & $4.764 \mathrm{E}-08$ & $6.213 \mathrm{E}-08$ & $7.900 \mathrm{E}-08$ \\
\hline PB211 & $2.160 \mathrm{E}-04$ & $2.253 \mathrm{E}-04$ & $2.341 \mathrm{E}-04$ & $2.423 \mathrm{E}-04$ & $2.537 \mathrm{E}-04$ & $2.704 \mathrm{E}-04$ & $2.846 \mathrm{E}-04$ & $2.968 \mathrm{E}-04$ \\
\hline PB212 & $3.120 \mathrm{E}-02$ & $3.058 \mathrm{E}-02$ & $3.000 \mathrm{E}-02$ & $2.943 E-02$ & $2.858 \mathrm{E}-02$ & $2.722 \mathrm{E}-02$ & $2.595 \mathrm{E}-02$ & $2.474 \mathrm{E}-02$ \\
\hline B|211 & $2.160 \mathrm{E}-04$ & $2.253 E-04$ & $2.341 \mathrm{E}-04$ & $2.423 E-04$ & $2.537 \mathrm{E}-04$ & $2.704 \mathrm{E}-04$ & $2.846 \mathrm{E}-04$ & $2.968 \mathrm{E}-04$ \\
\hline BI212 & $3.120 \mathrm{E}-02$ & $3.058 \mathrm{E}-02$ & 3.00 & $2.943 \mathrm{E}-02$ & $2.858 \mathrm{E}-02$ & $2.722 \mathrm{E}-02$ & $2.595 \mathrm{E}-02$ & $2.474 \mathrm{E}-02$ \\
\hline PO212 & -02 & $1.959 \mathrm{E}-02$ & $1.922 \mathrm{E}-02$ & $1.886 \mathrm{E}-02$ & $1.831 \mathrm{E}-02$ & $1.744 \mathrm{E}-02$ & $1.663 \mathrm{E}-02$ & $1.585 \mathrm{E}-02$ \\
\hline $\mathbf{P 0 2 1 5}$ & .04 & $2.253 \mathrm{E}-04$ & $2.341 E-04$ & $2.423 \mathrm{E}-04$ & $2.537 \mathrm{E}-04$ & $2.704 \mathrm{E}-04$ & $2.846 \mathrm{E}-04$ & $\begin{array}{l}2.968 \mathrm{E}-04 \\
\end{array}$ \\
\hline PO216 & $3.120 \mathrm{E}-02$ & $3.058 \mathrm{E}-02$ & $3.000 \mathrm{E}-02$ & $2.943 \mathrm{E}-02$ & $2.858 \mathrm{E} \cdot 02$ & $2.722 \mathrm{E}-02$ & $2.595 \mathrm{E}-02$ & $2.474 \mathrm{E}-02$ \\
\hline
\end{tabular}


Table 16. (continued).

\begin{tabular}{|c|c|c|c|c|c|c|c|c|}
\hline RN219 & $2.160 \mathrm{E}-04$ & 2.253E-04 & $2.341 \mathrm{E}-04$ & $2.423 \mathrm{E}-04$ & $2.537 \mathrm{E}-04$ & $2.704 \mathrm{E}-04$ & $2.846 \mathrm{E}-04$ & $2.968 \mathrm{E}-04$ \\
\hline RN220 & $3.120 \mathrm{E}-02$ & $3.058 \mathrm{E}-02$ & $3.000 \mathrm{E}-02$ & $2.943 E-02$ & $2.858 \mathrm{E}-02$ & $2.722 \mathrm{E}-02$ & $2.595 \mathrm{E}-02$ & $2.474 \mathrm{E}-02$ \\
\hline FR223 & 2.974E-06 & 3.103E-06 & 3.223E-06 & 3.337E-06 & 3.494E-06 & 3.724E-06 & $3.920 \mathrm{E}-06$ & $4.088 \mathrm{E}-06$ \\
\hline RA223 & 2.160 E- 04 & 2.253E-04 & $2.341 E-04$ & $2.423 \mathrm{E}-04$ & 2.537E-04 & $2.704 \mathrm{E}-04$ & $2.846 \mathrm{E}-04$ & $2.968 \mathrm{E}-04$ \\
\hline RA224 & $3.120 \mathrm{E}-02$ & $3.058 \mathrm{E}-02$ & $3.000 \mathrm{E}-02$ & $2.943 \mathrm{E}-02$ & $2.858 \mathrm{E}-02$ & $2.722 \mathrm{E}-02$ & 2.595E-02 & $2.474 \mathrm{E}-02$ \\
\hline RA226 & $6.635 \mathrm{E}-08$ & $7.456 \mathrm{E}-08$ & $8.325 \mathrm{E}-08$ & $9.239 \mathrm{E}-08$ & $1.070 \mathrm{E}-07$ & $1.336 \mathrm{E}-07$ & 1.631E-07 & 1.955E-07 \\
\hline RA228 & $1.607 \mathrm{E}-04$ & $1.622 \mathrm{E}-04$ & 1.634E-04 & $1.644 \mathrm{E}-04$ & $1.655 \mathrm{E}-04$ & $1.668 \mathrm{E}-04$ & $1.675 \mathrm{E}-04$ & $1.680 E-04$ \\
\hline AC227 & $2.155 \mathrm{E}-04$ & $2.248 \mathrm{E}-04$ & $2.336 \mathrm{E}-04$ & $2.418 \mathrm{E}-04$ & $2.532 \mathrm{E}-04$ & $2.699 \mathrm{E}-04$ & $2.841 \mathrm{E}-04$ & $2.962 E-04$ \\
\hline TH227 & $2.130 \mathrm{E}-04$ & $2.222 \mathrm{E}-04$ & $2.309 \mathrm{E}-04$ & $2.390 \mathrm{E}-04$ & $2.502 \mathrm{E}-04$ & $2.666 \mathrm{E}-04$ & $2.807 \mathrm{E}-04$ & $2.927 E-04$ \\
\hline TH228 & 3.109E-02 & $3.050 \mathrm{E}-02$ & 2.992E-02 & $2.936 \mathrm{E}-02$ & 2.853E-02 & $2.720 \mathrm{E}-02$ & $2.593 E-02$ & $2.472 E-02$ \\
\hline TH229 & $5.208 \mathrm{E}-04$ & $5.582 \mathrm{E}-04$ & $5.956 \mathrm{E}-04$ & $6.331 \mathrm{E}-04$ & $6.892 \mathrm{E}-04$ & $7.827 \mathrm{E}-04$ & $8.762 E-04$ & $9.696 \mathrm{E}-04$ \\
\hline TH230 & $9.283 \mathrm{E}-06$ & $9.826 \mathrm{E}-06$ & $1.037 \mathrm{E}-05$ & 1.091E-05 & 1.173E-05 & $1.309 \mathrm{E}-05$ & $1.444 \mathrm{E}-05$ & 1.581E-05 \\
\hline TH231 & 4.333E-04 & $4.333 \mathrm{E}-04$ & 4.333E-04 & 4.333E-04 & 4.333E-04 & 4.333E-04 & 4.333E-04 & $4.333 \mathrm{E}-04$ \\
\hline TH232 & $1.686 \mathrm{E}-04$ & $1.686 \mathrm{E}-04$ & $1.686 \mathrm{E}-04$ & $1.686 \mathrm{E}-04$ & $1.686 \mathrm{E}-04$ & $1.686 \mathrm{E}-04$ & $1.686 \mathrm{E}-04$ & $=-04$ \\
\hline TH234 & $4.730 \mathrm{E}-06$ & $4.730 \mathrm{E}-06$ & 4.7 & OE-06 & $4.730 \mathrm{E}-06$ & $4.730 \mathrm{E}-06$ & $4.730 \mathrm{E}-06$ & $4.730 \mathrm{E}-06$ \\
\hline PA231 & E-04 & $E-04$ & -04 & $3.666 \mathrm{E}-04$ & $3.666 \mathrm{E}-04$ & $3.666 \mathrm{E}-04$ & E-04 & 3.6 \\
\hline PA233 & $6.354 \mathrm{E}-04$ & $6.355 \mathrm{E}-04$ & 6.357E-04 & $6.358 \mathrm{E}-04$ & $6.361 \mathrm{E}-04$ & $6.365 \mathrm{E}-04$ & $6.370 \mathrm{E}-04$ & \\
\hline PA234M & $4.730 \mathrm{E}-06$ & 4.730E-06 & $4.730 \mathrm{E}-06$ & $4.730 \mathrm{E}-06$ & $4.730 \mathrm{E}-06$ & $4.730 \mathrm{E}-06$ & 4.730E-06 & \\
\hline PA234 & $6.149 \mathrm{E}-09$ & $6.148 \mathrm{E}-09$ & $6.148 \mathrm{E}-09$ & $6.148 \mathrm{E}-09$ & $6.148 \mathrm{E}-09$ & & -09 & $=-09$ \\
\hline U232 & $3.011 \mathrm{E}-02$ & $2.954 \mathrm{E}-02$ & 2.897E-02 & $2.842 \mathrm{E}-02$ & & -02 & E-02 & -02 \\
\hline U233 & & $1.988 \mathrm{E}-01$ & 1.9 & -01 & -01 & 01 & $\mathrm{E}-01$ & $=-01$ \\
\hline U234 & -02 & $E-02$ & 3.0 & -02 & -02 & -02 & -02 & $=-02$ \\
\hline U235 & 4.3 & -04 & 04 & 04 & -04 & -04 & & 04 \\
\hline U236 & 1.2 & -03 & -03 & -03 & -03 & -03 & -03 & 1.2 \\
\hline U237 & 6.4 & 5.9 & 5.3 & $=07$ & $4.214 \mathrm{E}-07$ & 3.3 & E-07 & 2.0 \\
\hline U238 & $4.730 \mathrm{E}-06$ & $4.730 \mathrm{E}-06$ & 4.730E-06 & $4.730 \mathrm{E}-06$ & $4.730 \mathrm{E}-06$ & E-06 & $4.730 \mathrm{E}-06$ & -06 \\
\hline NP237 & $6.354 \mathrm{E}-04$ & $6.355 \mathrm{E}-04$ & $6.357 \mathrm{E}-04$ & $6.358 \mathrm{E}-04$ & $6.361 \mathrm{E}-04$ & & $6.370 \mathrm{E}-04$ & -04 \\
\hline PU236 & 2.867E-08 & $1.766 \mathrm{E}-08$ & $1.089 \mathrm{E}-08$ & $6.724 \mathrm{E}-09$ & $3.279 \mathrm{E}-09$ & $1.024 \mathrm{E}-09$ & $7 \mathrm{E}-10$ & $=-10$ \\
\hline PU237 & $6.150 \mathrm{E}-69$ & $9.327 \mathrm{E}-74$ & E-78 & E-83 & $1.229 \mathrm{E}-90$ & +00 & $0 \mathrm{E}+00$ & $0 E+00$ \\
\hline PU238 & $E+00$ & +00 & +00 & $E+00$ & $1.707 \mathrm{E}+00$ & $E+00$ & +00 & $6 \mathrm{E}+00$ \\
\hline PU239 & $E-02$ & -02 & -02 & $4 E-02$ & -02 & .02 & E-02 & 2.8 \\
\hline PU240 & .02 & 2.4 & -02 & -02 & $2.456 \mathrm{E}-02$ & $2.455 \mathrm{E}-02$ & $2.454 \mathrm{E}-02$ & 2.45 \\
\hline PU241 & $2.649 \mathrm{E}+00$ & $2.406 \mathrm{E}+00$ & $2.185 \mathrm{E}+00$ & $1.985 \mathrm{E}+00$ & $1.718 \mathrm{E}+00$ & $1.350 \mathrm{E}+00$ & $1.062 E+00$ & $8.344 \mathrm{E}-01$ \\
\hline PU242 & $4.463 \mathrm{E}-05$ & 4.463E-05 & 4.463E-05 & 4.463E-05 & 4.463E-05 & 4.463E-05 & 4.463E-05 & E-05 \\
\hline PU244 & $2.359 \mathrm{E}-12$ & $2.359 \mathrm{E}-12$ & $2.359 \mathrm{E}-12$ & $2.359 \mathrm{E}-12$ & $2.359 \mathrm{E}-12$ & 5E-12 & EE-12 & $E-12$ \\
\hline AM241 & $=-01$ & 2.40 & $2.469 \mathrm{E}-01$ & E-01 & & 01 & & E-01 \\
\hline AM242N & -04 & 1.2 & $3 E-04$ & & & 1.1 & -04 & 1.1 \\
\hline AM242 & 1.2 & 1.25 & 1.2 & $5-04$ & 1.219E-04 & 1.1 & $1.165 \mathrm{E}-04$ & $8 E-04$ \\
\hline AM243 & $=-04$ & 1.6 & $E-04$ & $1.613 \mathrm{E}-04$ & 1.613E-04 & $1.612 \mathrm{E}-04$ & $1.611 \mathrm{E}-04$ & $1.610 \mathrm{E}-04$ \\
\hline CM242 & $1.052 \mathrm{E}-04$ & 1.04 & $1.033 \mathrm{E}-04$ & $1.024 \mathrm{E}-04$ & $1.010 \mathrm{E}-04$ & $9.858 \mathrm{E}-05$ & $9.636 \mathrm{E}-05$ & $9.419 \mathrm{E}-05$ \\
\hline CM243 & $1.428 \mathrm{E}-04$ & $1.360 \mathrm{E}-04$ & $1.295 \mathrm{E}-04$ & $1.234 \mathrm{E}-04$ & $1.147 \mathrm{E}-04$ & $1.016 \mathrm{E}-04$ & 8.995E-05 & $7.965 \mathrm{E}-05$ \\
\hline CM244 & $5.035 \mathrm{E}-03$ & $4.665 \mathrm{E}-03$ & $4.321 \mathrm{E} \cdot 03$ & $4.002 \mathrm{E}-03$ & $3.568 \mathrm{E}-03$ & $2.947 \mathrm{E}-03$ & $2.434 \mathrm{E}-03$ & $2.010 \mathrm{E}-03$ \\
\hline CM245 & $6.768 \mathrm{E}-07$ & $6.767 \mathrm{E}-07$ & $6.766 \mathrm{E}-07$ & $6.765 \mathrm{E}-07$ & $6.763 \mathrm{E}-07$ & $6.760 \mathrm{E}-07$ & $6.757 \mathrm{E}-07$ & E-07 \\
\hline CM246 & 2.599E-08 & $2.598 \mathrm{E}-08$ & $2.597 \mathrm{E}-08$ & $2.596 \mathrm{E}-08$ & $2.595 \mathrm{E}-08$ & $2.593 E-08$ & $2.591 \mathrm{E}-08$ & $2.589 \mathrm{E}-08$ \\
\hline CM247 & $3.671 \mathrm{E}-14$ & $3.671 \mathrm{E}-14$ & $3.671 \mathrm{E}-14$ & $3.671 \mathrm{E}-14$ & $3.671 \mathrm{E}-14$ & $3.671 \mathrm{E}-14$ & $3.671 \mathrm{E}-14$ & $3.671 \mathrm{E}-14$ \\
\hline Subtotal & $4.995 \mathrm{E}+02$ & $4.759 E+02$ & $4.535 E+02$ & $4.324 E+02$ & $4.025 E+02$ & $3.574 \mathrm{E}+02$ & $3.176 E+02$ & $2.824 E+02$ \\
\hline TOTAL & $4.995 \mathrm{E}+02$ & $4.759 E+02$ & $4.536 \mathrm{E}+02$ & $4.324 E+02$ & $4.025 \mathrm{E}+02$ & $3.574 \mathrm{E}+02$ & $3.176 E+02$ & $2.824 E+02$ \\
\hline
\end{tabular}


Table 17. Isotopic activity concentrations in curies for a single Peach Bottom Unit 1 Core 2 Type II fuel element (see Reference 22, Appendix 2, Table 2).

Information:

\author{
Units: CURES \\ Element Type: DRIVER \\ Burnup: $\quad 146.988 \mathrm{MWd}$ \\ Burnup: $\quad 90532$ MWDMTIHM \\ BOL U-235: 232.51 grams U-235 per element \\ BOL U-238: $\quad 12.1$ grams U-238 per element \\ BOL U-236: $\quad 1.25$ grams U-236 per element \\ BOL U-234: $\quad 3.74$ grams U-234 per element \\ BOL Th-232: $\quad 1374$ grams Th-232 per element \\ Fuel Meat: UC-ThC fuel kemel \\ Fuel Enrichment: $\quad 93.15$ wt\% U-235 \\ Clad: Graphite
}

\begin{tabular}{|c|c|c|c|c|c|c|c|c|}
\hline ISOTOPE & 1-Jul-96 & 1-Jul-98 & 1-Jul-00 & 1-Jul-02 & 1-Jul-05 & 1-Jul-10 & 1-Jul-15 & 1-Jul-20 \\
\hline H 3 & $1.901 E+00$ & $1.699 \mathrm{E}+00$ & $1.519 \mathrm{E}+00$ & $1.357 \mathrm{E}+00$ & $1.147 \mathrm{E}+00$ & $8.663 \mathrm{E}-01$ & 6.544E-01 & $4.941 \mathrm{E}-01$ \\
\hline BE 10 & $1.211 \mathrm{E}-04$ & $1.211 \mathrm{E}-04$ & $1.211 \mathrm{E}-04$ & $1.211 \mathrm{E}-04$ & $1.211 \mathrm{E}-04$ & $1.211 \mathrm{E}-04$ & $1.211 E-04$ & $1.211 \mathrm{E}-04$ \\
\hline C 14 & $8.344 E-03$ & $8.342 E-03$ & $8.340 \mathrm{E}-03$ & $8.338 \mathrm{E}-03$ & $8.335 \mathrm{E}-03$ & 8.329E-03 & $8.324 E-03$ & $8.319 E-03$ \\
\hline CL 36 & 2.122E-04 & $2.122 \mathrm{E}-04$ & $2.122 \mathrm{E}-04$ & $2.122 \mathrm{E}-04$ & $2.122 E-04$ & $2.122 E-04$ & 2.122E-04 & $2.122 E-04$ \\
\hline CR 51 & $0.000 E+00$ & $0.000 E+00$ & $0.000 E+00$ & $0.000 E+00$ & $0.000 \mathrm{E}+00$ & $0.000 \mathrm{E}+00$ & $0.000 \mathrm{E}+00$ & $0.000 \mathrm{E}+00$ \\
\hline MN 54 & $4.883 E-09$ & $9.672 \mathrm{E}-10$ & $1.911 E-10$ & $3.786 \mathrm{E}-11$ & $3.329 \mathrm{E}-12$ & $5.799 \mathrm{E}-14$ & $1.010 \mathrm{E}-15$ & $1.756 \mathrm{E}-17$ \\
\hline FE 55 & $4.225 \mathrm{E}-03$ & $2.480 \mathrm{E}-03$ & $1.455 \mathrm{E}-03$ & $8.538 \mathrm{E}-04$ & $3.836 \mathrm{E}-04$ & $1.012 \mathrm{E}-04$ & $2.669 \mathrm{E}-05$ & 7.033E-06 \\
\hline FE 59 & $0.000 E+00$ & $0.000 \mathrm{E}+00$ & $0.000 E+00$ & $0.000 \mathrm{E}+00$ & $0.000 \mathrm{E}+00$ & $0.000 \mathrm{E}+00$ & $0.000 \mathrm{E}+00$ & $0.000 E+00$ \\
\hline Co 60 & $7.688 \mathrm{E}-01$ & $5.911 \mathrm{E}-01$ & $4.543 \mathrm{E}-01$ & 3.492E-01 & 2.354E-01 & $1.219 \mathrm{E}-01$ & $6.318 \mathrm{E}-02$ & $3.272 \mathrm{E}-02$ \\
\hline NI 59 & 2.795E-04 & $2.795 \mathrm{E}-04$ & $2.795 \mathrm{E}-04$ & 2.795E-04 & 2.795E-04 & $2.795 \mathrm{E}-04$ & $2.794 \mathrm{E}-04$ & $2.794 \mathrm{E}-04$ \\
\hline NI 63 & $3.138 \mathrm{E}-02$ & 3.091E-02 & $3.044 \mathrm{E}-02$ & $2.999 \mathrm{E}-02$ & $2.932 \mathrm{E}-02$ & 2.823E-02 & 2.719E-02 & $2.619 \mathrm{E}-02$ \\
\hline ZN 65 & $1.704 \mathrm{E}-11$ & $2.140 \mathrm{E}-12$ & $2.679 \mathrm{E}-13$ & $3.364 \mathrm{E}-14$ & $1.493 \mathrm{E}-15$ & $8.316 \mathrm{E}-18$ & $4.633 \mathrm{E}-20$ & $2.574 \mathrm{E}-22$ \\
\hline SE 79 & $2.436 \mathrm{E}-03$ & $2.436 \mathrm{E}-03$ & $2.436 \mathrm{E}-03$ & $2.436 \mathrm{E}-03$ & $2.436 \mathrm{E}-03$ & $2.436 \mathrm{E}-03$ & $2.436 \mathrm{E}-03$ & $2.436 \mathrm{E}-03$ \\
\hline KR 85 & $1.427 E+01$ & $1.254 \mathrm{E}+01$ & $1.102 E+01$ & $9.681 E+00$ & $7.974 \mathrm{E}+00$ & $5.771 \mathrm{E}+00$ & $4.177 \mathrm{E}+00$ & $3.023 E+00$ \\
\hline AB 87 & $1.400 \mathrm{E}-07$ & $1.400 \mathrm{E}-07$ & $1.400 \mathrm{E}-07$ & $1.400 \mathrm{E}-07$ & $1.400 \mathrm{E}-07$ & $1.400 \mathrm{E}-07$ & $1.400 \mathrm{E}-07$ & $1.400 \mathrm{E}-07$ \\
\hline SR 89 & $0.000 E+00$ & $0.000 \mathrm{E}+00$ & $0.000 \mathrm{E}+00$ & $0.000 \mathrm{E}+00$ & $0.000 E+00$ & $0.000 E+00$ & $0.000 E+00$ & $0.000 E+00$ \\
\hline SR 90 & $2.656 \mathrm{E}+02$ & $2.533 \mathrm{E}+02$ & $2.415 E+02$ & $2.303 E+02$ & $2.144 E+02$ & $1.903 E+02$ & $1.690 \mathrm{E}+02$ & $1.500 E+02$ \\
\hline Y 90 & $2.657 E+02$ & $2.533 \mathrm{E}+02$ & $2.415 \mathrm{E}+02$ & $2.303 E+02$ & $2.144 E+02$ & $1.904 E+02$ & $1.690 \mathrm{E}+02$ & $1.501 E+02$ \\
\hline Y 91 & $1.020 \mathrm{E}-37$ & $1.789 \mathrm{E}-41$ & $3.100 \mathrm{E}-45$ & $5.437 \mathrm{E}-49$ & $1.248 E-54$ & $5.024 E-64$ & $2.023 \mathrm{E}-73$ & $8.048 \mathrm{E}-83$ \\
\hline ZR 93 & $9.829 \mathrm{E}-03$ & $9.829 \mathrm{E}-03$ & $9.829 \mathrm{E}-03$ & $9.829 \mathrm{E}-03$ & $9.829 \mathrm{E}-03$ & $9.829 \mathrm{E}-03$ & $9.829 \mathrm{E}-03$ & $9.829 \mathrm{E}-03$ \\
\hline ZR 95 & $3.241 E-34$ & $1.191 \mathrm{E}-37$ & $4.332 E-41$ & $1.592 E-44$ & $1.110 \mathrm{E}-49$ & $2.846 \mathrm{E}-58$ & $7.293 E-67$ & $1.849 \mathrm{E}-75$ \\
\hline NB 93M & $6.569 \mathrm{E}-03$ & $6.837 \mathrm{E}-03$ & $7.080 \mathrm{E}-03$ & $7.298 \mathrm{E}-03$ & $7.587 \mathrm{E}-03$ & $7.981 \mathrm{E}-03$ & $8.286 \mathrm{E}-03$ & $8.523 E-03$ \\
\hline NB 94 & $9.850 \mathrm{E}-05$ & $9.850 \mathrm{E}-05$ & $9.849 \mathrm{E}-05$ & $9.848 \mathrm{E}-05$ & 9.847E-05 & $9.846 \mathrm{E}-05$ & $9.844 \mathrm{E}-05$ & $9.842 \mathrm{E}-05$ \\
\hline NB 95 & $7.198 \mathrm{E}-34$ & $2.645 \mathrm{E}-37$ & $9.617 \mathrm{E}-41$ & $3.535 \mathrm{E}-44$ & $2.465 \mathrm{E}-49$ & $6.318 \mathrm{E}-58$ & $1.619 \mathrm{E}-66$ & $4.105 \mathrm{E}-75$ \\
\hline NB 95M & $2.404 \mathrm{E}-36$ & $8.837 E-40$ & $3.214 E-43$ & $1.181 \mathrm{E}-46$ & $8.237 \mathrm{E}-52$ & $2.111 \mathrm{E}-60$ & $5.411 \mathrm{E}-69$ & $1.372 E-77$ \\
\hline MO 93 & $3.291 \mathrm{E}-06$ & $3.290 \mathrm{E}-06$ & $3.289 \mathrm{E}-06$ & $3.287 \mathrm{E}-06$ & $3.285 E-06$ & $3.282 \mathrm{E}-06$ & $3.279 \mathrm{E}-06$ & $3.276 E-06$ \\
\hline TC 99 & $5.556 \mathrm{E}-02$ & 5.555E-02 & $5.555 \mathrm{E}-02$ & 5.555E-02 & $5.555 \mathrm{E}-02$ & $5.555 \mathrm{E}-02$ & $5.555 \mathrm{E}-02$ & $5.555 \mathrm{E}-02$ \\
\hline RU103 & $0.000 E+00$ & $0.000 \mathrm{E}+00$ & $0.000 \mathrm{E}+00$ & $0.000 E+00$ & $0.000 E+00$ & $0.000 E+00$ & $0.000 E+00$ & $0.000 E+00$ \\
\hline RU106 & $1.134 \mathrm{E}-04$ & $2.870 \mathrm{E}-05$ & $7.248 \mathrm{E}-06$ & $1.834 \mathrm{E}-06$ & $2.329 \mathrm{E}-07$ & $7.485 \mathrm{E}-09$ & $2.406 \mathrm{E}-10$ & $7.716 \mathrm{E}-12$ \\
\hline RH103M & $0.000 E+00$ & $0.000 \mathrm{E}+00$ & $0.000 E+00$ & $0.000 E+00$ & $0.000 \mathrm{E}+00$ & $0.000 E+00$ & $0.000 E+00$ & $0.000 E+00$ \\
\hline RH106 & $1.134 \mathrm{E}-04$ & $2.870 \mathrm{E}-05$ & $7.248 \mathrm{E}-06$ & 1.834E-06 & 2.329E-07 & $7.485 \mathrm{E}-09$ & $2.406 \mathrm{E}-10$ & $7.716 \mathrm{E}-12$ \\
\hline PD107 & $7.625 \mathrm{E}-05$ & $7.625 \mathrm{E}-05$ & $7.625 \mathrm{E}-05$ & $7.625 \mathrm{E}-05$ & $7.625 \mathrm{E}-05$ & $7.625 \mathrm{E}-05$ & $7.625 \mathrm{E}-05$ & $7.625 \mathrm{E}-05$ \\
\hline AG110 & $9.655 \mathrm{E}-12$ & $1.274 \mathrm{E}-12$ & $1.678 \mathrm{E}-13$ & $2.215 \mathrm{E}-14$ & $1.059 \mathrm{E}-15$ & $6.687 \mathrm{E}-18$ & $4.221 \mathrm{E}-20$ & $2.658 \mathrm{E}-22$ \\
\hline AG110M & $7.260 \mathrm{E}-10$ & $9.582 \mathrm{E}-11$ & $1.262 \mathrm{E}-11$ & $1.666 \mathrm{E}-12$ & $7.963 \mathrm{E}-14$ & $5.027 \mathrm{E}-16$ & $3.174 \mathrm{E}-18$ & $1.998 \mathrm{E}-20$ \\
\hline AG111 & $0.000 E+00$ & $0.000 E+00$ & $0.000 \mathrm{E}+00$ & $0.000 E+00$ & $0.000 E+00$ & $0.000 E+00$ & $0.000 E+00$ & $0.000 \mathrm{E}+00$ \\
\hline CD113M & $2.168 \mathrm{E}-02$ & $1.972 \mathrm{E}-02$ & $1.793 \mathrm{E}-02$ & $1.631 \mathrm{E}-02$ & $1.414 \mathrm{E}-02$ & $1.115 \mathrm{E}-02$ & $8.793 \mathrm{E}-03$ & $6.933 \mathrm{E}-03$ \\
\hline CD113 & $0.000 E+00$ & $0.000 \mathrm{E}+00$ & $0.000 \mathrm{E}+00$ & $0.000 E+00$ & $0.000 \mathrm{E}+00$ & $0.000 E+00$ & $0.000 E+00$ & $0.000 E+00$ \\
\hline CD115M & $0.000 \mathrm{E}+00$ & $0.000 \mathrm{E}+00$ & $0.000 \mathrm{E}+00$ & $0.000 E+00$ & $0.000 \mathrm{E}+00$ & $0.000 E+00$ & $0.000 E+00$ & $0.000 \mathrm{E}+00$ \\
\hline
\end{tabular}


Table 17. (continued).

\begin{tabular}{|c|c|c|c|c|c|c|c|c|}
\hline IN114 & $0.000 \mathrm{E}+00$ & $0.000 E+00$ & $0.000 E+00$ & $0.000 E+00$ & $0.000 E+00$ & $0.000 E+00$ & $0.000 E+00$ & $E+\infty 0$ \\
\hline IN114M & $0.000 E+00$ & $0.000 E+00$ & $0.000 \mathrm{E}+00$ & $0.000 \mathrm{E}+00$ & $0.000 E+00$ & $0.000 E+00$ & $0.000 E+00$ & $0.000 E+00$ \\
\hline IN115M & $0.000 E+00$ & $0.000 \mathrm{E}+00$ & $0.000 \mathrm{E}+00$ & $0.000 E+00$ & $0.000 E+00$ & $0.000 E+00$ & $0.000 E+00$ & $0.000 E+00$ \\
\hline SN119M & $5.385 \mathrm{E} \cdot 11$ & $6.829 \mathrm{E}-12$ & $8.635 \mathrm{E}-13$ & $1.095 \mathrm{E}-13$ & $4.930 \mathrm{E}-15$ & $2.815 \mathrm{E}-17$ & 1.607E-19 & $9.151 \mathrm{E}-22$ \\
\hline SN121M & $5.022 \mathrm{E}-04$ & $4.885 \mathrm{E}-04$ & $4.751 E-04$ & $4.621 \mathrm{E}-04$ & $4.433 \mathrm{E}-04$ & $4.136 \mathrm{E}-04$ & $3.859 \mathrm{E} \cdot 04$ & $3.601 \mathrm{E}-04$ \\
\hline SN123 & $2.152 E-18$ & 4.280E-20 & $8.470 \mathrm{E}-22$ & $1.685 \mathrm{E} \cdot 23$ & $4.703 \mathrm{E}-26$ & $2.611 \mathrm{E}-30$ & $1.449 \mathrm{E}-34$ & $8.002 E-39$ \\
\hline SN125 & $0.000 E+00$ & $0.000 \mathrm{E}+00$ & $0.000 \mathrm{E}+00$ & $0.000 E+00$ & $0.000 E+00$ & $0.000 E+00$ & $0.000 E+00$ & $0.000 \mathrm{E}+00$ \\
\hline SN126 & $2.398 \mathrm{E}-03$ & $2.398 \mathrm{E}-03$ & $2.398 \mathrm{E}-03$ & $2.398 \mathrm{E} \cdot 03$ & $2.398 \mathrm{E}=03$ & $2.398 \mathrm{E}-03$ & $2.398 \mathrm{E}-03$ & 2.398E-03 \\
\hline SB124 & $1.524 \mathrm{E}-39$ & $3.407 E-43$ & $7.530 \mathrm{E}-47$ & $1.684 \mathrm{E} \cdot 50$ & $5.564 \mathrm{E}-56$ & $4.111 \mathrm{E}-65$ & $3.038 \mathrm{E}-74$ & $2.219 \mathrm{E} \cdot 83$ \\
\hline SB125 & $1.338 \mathrm{E}-01$ & $8.109 \mathrm{E}-02$ & 4.915E-02 & $2.980 \mathrm{E}-02$ & $1.407 \mathrm{E}-02$ & 4.026E-03 & $1.152 \mathrm{E}-03$ & $3.295 \mathrm{E}=04$ \\
\hline SB126 & $3.357 \mathrm{E}-04$ & $3.357 \mathrm{E}-04$ & 3.357E-04 & 3.357E-04 & $3.357 \mathrm{E}-04$ & $3.357 \mathrm{E}-04$ & $3.357 \mathrm{E}-04$ & $3.357 \mathrm{E}-04$ \\
\hline SB126M & $2.398 \mathrm{E}-03$ & 2.398E-03 & 2.398E-03 & $2.398 \mathrm{E}-03$ & $2.398 \mathrm{E}-03$ & 2.398E-03 & $2.398 \mathrm{E}-03$ & $2.398 \mathrm{E}-03$ \\
\hline TE123M & $8.070 \mathrm{E}-22$ & $1.177 \mathrm{E}-23$ & $1.706 \mathrm{E}-25$ & $2.487 \mathrm{E}-27$ & $4.354 \mathrm{E}-30$ & $1.111 \mathrm{E}-34$ & $2.836 \mathrm{E}-39$ & $7.196 \mathrm{E}-44$ \\
\hline TE125M & $3.266 \mathrm{E}-02$ & $1.979 \mathrm{E}-02$ & $1.200 \mathrm{E}-02$ & $7.274 \mathrm{E}-03$ & $3.432 \mathrm{E}-03$ & $9.822 \mathrm{E}-04$ & 2.811E-04 & $8.040 \mathrm{E}-05$ \\
\hline TE127 & $5.794 \mathrm{E}-21$ & $5.585 \mathrm{E}-23$ & $5.349 \mathrm{E}-25$ & $5.156 \mathrm{E}-27$ & $4.848 \mathrm{E}-30$ & $4.394 \mathrm{E}-35$ & $3.982 E-40$ & $3.586 \mathrm{E}-45$ \\
\hline TE127M & $5.916 \mathrm{E}-21$ & $5.702 E-23$ & $5.461 \mathrm{E}-25$ & $5.264 \mathrm{E}-27$ & $4.949 \mathrm{E}-30$ & $4.486 \mathrm{E}-35$ & $4.065 E-40$ & $3.661 \mathrm{E}-45$ \\
\hline TE129 & $0.000 E+00$ & $0.000 E+00$ & $0.000 \mathrm{E}+00$ & $0.000 E+00$ & $0.000 E+00$ & $0.000 E+00$ & $0.000 E+00$ & $0.000 E+00$ \\
\hline TE129M & $0.000 E+00$ & $0.000 E+00$ & $0.000 E+00$ & $0.000 E+00$ & $0.000 E+00$ & $0.000 E+00$ & $0.000 \mathrm{E}+00$ & $0.000 \mathrm{E}+00$ \\
\hline 1129 & $1.251 \mathrm{E}-04$ & $1.251 \mathrm{E}-04$ & $1.251 \mathrm{E}-04$ & $1.251 \mathrm{E}-04$ & $1.251 \mathrm{E}-04$ & $1.251 \mathrm{E}-04$ & 1.251E-04 & $1.251 \mathrm{E}-04$ \\
\hline 1131 & $0.000 \mathrm{E}+00$ & $0.000 \mathrm{E}+00$ & $0.000 E+00$ & $0.000 E+00$ & $0.000 \mathrm{E}+00$ & $0.000 E+00$ & $0.000 \mathrm{E}+00$ & $0.000 E+00$ \\
\hline XE131M & $0.000 \mathrm{E}+00$ & $0.000 E+00$ & $0.000 E+00$ & $0.000 E+00$ & $0.000 \mathrm{E}+00$ & $0.000 E+00$ & $0.000 E+00$ & $0.000 E+00$ \\
\hline XE133 & $0.000 E+00$ & $0.000 E+00$ & $0.000 E+00$ & $0.000 E+00$ & $0.000 E+00$ & $0.000 E+00$ & $0.000 \mathrm{E}+00$ & $0.000 E+00$ \\
\hline CS134 & $5.325 \mathrm{E}-01$ & $2.719 \mathrm{E}-01$ & $1.388 \mathrm{E}-01$ & $7.088 \mathrm{E}-02$ & $2.585 \mathrm{E}-02$ & $4.814 \mathrm{E}-03$ & $8.968 \mathrm{E}-04$ & $E-04$ \\
\hline Cs135 & $3.150 \mathrm{E}-03$ & $3.150 \mathrm{E}-03$ & $3.150 \mathrm{E}-03$ & $3.150 \mathrm{E}-03$ & $3.150 \mathrm{E} \cdot 03$ & $3.150 \mathrm{E}-03$ & $3.150 \mathrm{E}-03$ & $3.150 E-03$ \\
\hline CS136 & $0.000 E+00$ & $0.000 E+00$ & +00 & $0.000 \mathrm{E}+00$ & $0.000 \mathrm{E}+00$ & $0.000 \mathrm{E}+00$ & $0.000 E+00$ & $E+00$ \\
\hline Cs137 & $2.784 \mathrm{E}+02$ & $2.659 \mathrm{E}+02$ & $2.538 \mathrm{E}+02$ & $2.424 \mathrm{E}+02$ & $2.262 E+02$ & $2.015 \mathrm{E}+02$ & $1.795 \mathrm{E}+02$ & $1.599 \mathrm{E}+02$ \\
\hline BA136M & 0,000 & 0.00 & $0.000 E+00$ & $0.000 E+00$ & $E+00$ & $8+00$ & +00 & $E+00$ \\
\hline BA137M & $2.634 \mathrm{E}+02$ & $2.515 \mathrm{E}+02$ & $2.401 \mathrm{E}+02$ & $2.293 \mathrm{E}+02$ & $2.139 \mathrm{E}+02$ & $1.906 \mathrm{E}+02$ & $1.698 \mathrm{E}+02$ & $1.513 E+02$ \\
\hline BA140 & $0.000 \mathrm{E}+00$ & $0.000 E+00$ & $0.000 E+00$ & $0.000 E+00$ & $E+00$ & +00 & +00 & $E+00$ \\
\hline LA140 & $0.000 \mathrm{E}+00$ & $0.000 E+00$ & $0.000 E+00$ & $0.000 \mathrm{E}+00$ & $0.000 \mathrm{E}+00$ & $0.000 E+00$ & $0.000 E+00$ & $0.000 \mathrm{E}+00$ \\
\hline CE141 & 0.000 & $0.000 E+00$ & $0.000 \mathrm{E}+00$ & $E+00$ & $E+00$ & +00 & $0.000 E+00$ & $0.000 E+00$ \\
\hline CE142 & $1.333 \mathrm{E}-07$ & 1.333E-07 & $1.333 \mathrm{E}-07$ & 1.333E-07 & $1.333 \mathrm{E}-07$ & 1.333E-07 & 1.333E-07 & 1.333E-07 \\
\hline CE144 & $1.689 \mathrm{E}-05$ & $2.848 E-06$ & $4.791 \mathrm{E}-07$ & $8.078 \mathrm{E}-08$ & $5.580 \mathrm{E}-09$ & $E=11$ & $7.572 \mathrm{E}-13$ & $8.798 \mathrm{E}-15$ \\
\hline PR143 & $0.000 \mathrm{E}+00$ & $0,000 E+00$ & $0.000 E+00$ & $0.000 E+00$ & +00 & $+\infty 0$ & $0.000 \mathrm{E}+00$ & $E+00$ \\
\hline PR144 & $1.689 \mathrm{E}-05$ & $2.848 \mathrm{E}-06$ & $4.791 \mathrm{E}-07$ & $8.079 \mathrm{E}-08$ & $5.580 \mathrm{E}-09$ & $6.500 \mathrm{E}-11$ & $7.572 \mathrm{E}-13$ & $8.799 \mathrm{E}-15$ \\
\hline PR144M & 2.027E-07 & $3.417 \mathrm{E}-08$ & $5.749 \mathrm{E}-09$ & $9.694 \mathrm{E}-10$ & $E=11$ & -13 & $9.086 \mathrm{E}-15$ & $1.056 \mathrm{E}-16$ \\
\hline ND144 & $7.442 \mathrm{E}-12$ & $7.442 \mathrm{E}-12$ & $7.442 \mathrm{E}-12$ & $7.442 \mathrm{E}-12$ & $7.442 \mathrm{E}-12$ & $7.442 \mathrm{E}-12$ & $7.442 \mathrm{E}=12$ & $7.442 \mathrm{E}-12$ \\
\hline ND147 & $0.000 E+00$ & $0.000 \mathrm{E}+00$ & $0.000 E+00$ & $0.000 E+00$ & $0.000 E+00$ & $0.000 \mathrm{E}+00$ & $0.000 E+00$ & $0.000 E+00$ \\
\hline PM145 & $4.885 \mathrm{E}-05$ & $4.518 \mathrm{E}-05$ & $4.177 \mathrm{E}-05$ & 3.863E-05 & $3.434 \mathrm{E}-05$ & $2.824 \mathrm{E}-05$ & $2.322 \mathrm{E}-05$ & $1.909 \mathrm{E}-05$ \\
\hline PM147 & $1.598 \mathrm{E}+00$ & 9.422E-01 & 5.553E-01 & $3.275 \mathrm{E}-01$ & 1.482E-01 & -02 & $1.056 \mathrm{E}-02$ & $2.816 \mathrm{E}-03$ \\
\hline PM148M & $0.000 \mathrm{E}+00$ & $0.000 \mathrm{E}+00$ & $0.000 E+00$ & $0.000 E+00$ & $0.000 \mathrm{E}+00$ & $0.000 E+00$ & $0.000 \mathrm{E}+00$ & $0.000 \mathrm{E}+00$ \\
\hline PM148 & $0.000 \mathrm{E}+00$ & $0.000 E+00$ & $0.000 E+00$ & $0.000 E+00$ & $0.000 E+00$ & $0.000 E+00$ & $0.000 E+00$ & $0.000 E+00$ \\
\hline SM145 & $7.623 \mathrm{E}-11$ & $1.721 \mathrm{E}-11$ & $3.879 \mathrm{E}-12$ & $8.760 \mathrm{E}-13$ & $9.382 \mathrm{E}-14$ & $2.269 \mathrm{E}-15$ & $5.487 \mathrm{E}-17$ & $1.324 E-18$ \\
\hline SM147 & $2.060 \mathrm{E}-08$ & 2.062E-08 & $2.063 \mathrm{E}-08$ & $2.063 \mathrm{E}-08$ & $E-08$ & -08 & $2.064 \mathrm{E}-08$ & $2.064 \mathrm{E}-08$ \\
\hline SM151 & $1.862 E+00$ & $1.833 \mathrm{E}+00$ & $1.805 \mathrm{E}+00$ & $1.778 E+00$ & $1.737 \mathrm{E}+00$ & $1.672 E+00$ & $1.609 \mathrm{E}+00$ & $1.548 E+00$ \\
\hline EU152 & $3.258 \mathrm{E}-02$ & 2.942E-02 & .02 & $2.400 \mathrm{E}-02$ & $2.059 \mathrm{E}-02$ & $1.596 \mathrm{E}-02$ & 1.237E-02 & $9.588 \mathrm{E} \cdot 03$ \\
\hline EU154 & $5.691 E+00$ & $4.845 \mathrm{E}+00$ & $4.123 E+00$ & $3.509 E+00$ & $2.756 \mathrm{E}+00$ & $1.841 \mathrm{E}+00$ & $1.231 E+00$ & $8.225 \mathrm{E}-01$ \\
\hline EU155 & $9.087 \mathrm{E}-01$ & $=01$ & $=01$ & $3.929 \mathrm{E}-01$ & $2.583 \mathrm{E}-01$ & $1.284 \mathrm{E}-01$ & $6.386 \mathrm{E}-02$ & $3.174 \mathrm{E}-02$ \\
\hline EU156 & $0.000 E+00$ & $0.000 E+00$ & $0.000 E+00$ & $0.000 E+00$ & $0.000 \mathrm{E}+00$ & $0.000 E+00$ & $0.000 \mathrm{E}+00$ & $0.000 E+00$ \\
\hline GD153 & $4.346 \mathrm{E}-11$ & $5.371 \mathrm{E}-12$ & $6.618 \mathrm{E}-13$ & $8.179 \mathrm{E}-14$ & $3.544 \mathrm{E}-15$ & 1.897E-17 & $1.016 \mathrm{E}-19$ & $5.424 \mathrm{E}-22$ \\
\hline TB160 & $3.298 \mathrm{E}-33$ & $3.012 \mathrm{E}-36$ & $2.725 \mathrm{E}-39$ & $2.489 \mathrm{E}-42$ & $6.807 \mathrm{E}-47$ & $1.701 \mathrm{E}-54$ & 4.247E-62 & \\
\hline TL206 & 1.313E-09 & $1.313 \mathrm{E}-09$ & $1.313 \mathrm{E}-09$ & 1.313E-09 & 1.313E-09 & $1.313 \mathrm{E}-09$ & $1.313 \mathrm{E}-09$ & $1.313 \mathrm{E}-09$ \\
\hline TL207 & $3.112 E-04$ & $3.285 E-04$ & & $3.601 E-04$ & 3.813 & $4.123 \mathrm{E}-04$ & $4.388 \mathrm{E}-04$ & $4.614 \mathrm{E}-04$ \\
\hline TL208 & $4.947 \mathrm{E}-02$ & $4.852 \mathrm{E}-02$ & $4.760 \mathrm{E}-02$ & $4.670 \mathrm{E}-02$ & $4.534 \mathrm{E}-02$ & $4.317 \mathrm{E}-02$ & $4.114 \mathrm{E}-02$ & $3.921 \mathrm{E}-02$ \\
\hline PB210 & $3.656 \mathrm{E} \cdot 08$ & $3.952 \mathrm{E}-08$ & $4.296 \mathrm{E}-08$ & $4.688 \mathrm{E}-08$ & $5.368 \mathrm{E} \cdot 08$ & $6.752 E-08$ & $8.457 \mathrm{E}-08$ & $1.049 \mathrm{E}-07$ \\
\hline PB211 & $3.121 \mathrm{E}-04$ & $3.295 \mathrm{E}-04$ & $3.458 \mathrm{E}-04$ & $3.611 \mathrm{E}-04$ & $3.823 \mathrm{E} \cdot 04$ & $4.134 \mathrm{E}-04$ & $4.400 \mathrm{E}-04$ & $4.627 \mathrm{E}-04$ \\
\hline PB212 & $1.377 \mathrm{E}-01$ & $1.350 \mathrm{E}-01$ & $1.325 \mathrm{E}-01$ & $1.300 \mathrm{E}-01$ & 1.262E-01 & $1.202 \mathrm{E}-01$ & $1.145 \mathrm{E}-01$ & $1.091 \mathrm{E}-01$ \\
\hline B1211 & $3.121 \mathrm{E}-04$ & $3.295 \mathrm{E}-04$ & $3.458 \mathrm{E}-04$ & $3.611 \mathrm{E}-04$ & $3.823 \mathrm{E} \cdot 04$ & $4.134 \mathrm{E}-04$ & $4.400 \mathrm{E}-04$ & $4.627 \mathrm{E}-04$ \\
\hline B1212 & $1.377 \mathrm{E}-01$ & $1.350 \mathrm{E}-01$ & $1.325 \mathrm{E}-01$ & $1.300 \mathrm{E}-01$ & $1.262 E \cdot 01$ & $1.202 \mathrm{E}-01$ & $1.145 \mathrm{E}-01$ & $1.091 \mathrm{E}-01$ \\
\hline PO212 & $8.822 \mathrm{E}-02$ & $8.652 \mathrm{E} \cdot 02$ & $8.488 \mathrm{E}-02$ & $8.327 \mathrm{E}-02$ & $8.084 \mathrm{E}-02$ & $7.698 \mathrm{E}-02$ & $7.337 \mathrm{E}-02$ & $6.992 \mathrm{E}-02$ \\
\hline P0215 & & & $3.458 \mathrm{E}-04$ & $3.611 \mathrm{E}-04$ & $3.823 \mathrm{E}-04$ & $4,134 \mathrm{E} \cdot 04$ & $4.400 \mathrm{E}-04$ & $4.627 \mathrm{E}-04$ \\
\hline
\end{tabular}


Table 17. (continued).

\begin{tabular}{|c|c|c|c|c|c|c|c|c|}
\hline P0216 & 1.377E-01 & $1.350 \mathrm{E}-01$ & $1.325 \mathrm{E}-01$ & $1.300 \mathrm{E}-01$ & $1.262 \mathrm{E}-01$ & $1.202 \mathrm{E}-01$ & $1.145 \mathrm{E}-01$ & 1.091E-01 \\
\hline RN219 & $3.121 \mathrm{E}-04$ & $3.295 \mathrm{E}-04$ & $3.458 \mathrm{E}-04$ & $3.611 \mathrm{E}-04$ & $3.823 \mathrm{E}-04$ & $4.134 \mathrm{E}-04$ & $4.400 \mathrm{E}-04$ & 4.627E-04 \\
\hline RN220 & $1.377 \mathrm{E}-01$ & $1.350 \mathrm{E}-01$ & 1.325E-01 & $1.300 \mathrm{E}-01$ & $1.262 \mathrm{E}-01$ & $1.202 \mathrm{E}-01$ & $1.145 \mathrm{E}-01$ & $1.091 \mathrm{E}-01$ \\
\hline FR223 & $4.298 \mathrm{E}-06$ & 4.537E-06 & 4.762E-06 & 4.973E-06 & $5.266 \mathrm{E}-06$ & $5.695 \mathrm{E}-06$ & $6.061 \mathrm{E}-06$ & $6.373 E-06$ \\
\hline RA223 & 3.121E-04 & 3.295E-04 & $3.458 \mathrm{E}-04$ & $3.611 \mathrm{E}-04$ & $3.823 E-04$ & $4.134 \mathrm{E}-04$ & $4.400 \mathrm{E}-04$ & 4.627E-04 \\
\hline RA224 & 1.377E-01 & $1.350 \mathrm{E}-01$ & $1.325 \mathrm{E}-01$ & $1.300 \mathrm{E}-01$ & $1.262 \mathrm{E}-01$ & $1.202 \mathrm{E}-01$ & $1.145 \mathrm{E}-01$ & $1.091 \mathrm{E}-01$ \\
\hline RA226 & $8.048 \mathrm{E}-08$ & $9.105 \mathrm{E}-08$ & 1.022E-07 & $1.140 \mathrm{E}-07$ & 1.327E-07 & $1.670 \mathrm{E}-07$ & 2.050 E- 07 & 2.467E-07 \\
\hline RA228 & 1.342E-04 & $1.360 \mathrm{E}-04$ & 1.375E-04 & $1.387 \mathrm{E}-04$ & $1.402 \mathrm{E}-04$ & 1.417E-04 & 1.427E-04 & 1.432E-04 \\
\hline AC227 & $3.114 \mathrm{E}-04$ & $3.288 E-04$ & $3.451 \mathrm{E}-04$ & $3.604 \mathrm{E}-04$ & 3.816E-04 & 4.127E-04 & 4.392E-04 & $4.618 \mathrm{E}-04$ \\
\hline TH227 & $3.078 E-04$ & $3.249 \mathrm{E}-04$ & $3.410 \mathrm{E}-04$ & $3.561 \mathrm{E}-04$ & $3.771 \mathrm{E}-04$ & 4.077E-04 & $4.339 \mathrm{E}-04$ & $4.563 \mathrm{E}-04$ \\
\hline TH228 & 1.373E-01 & $1.347 \mathrm{E}-01$ & $1.321 \mathrm{E}-01$ & $1.296 \mathrm{E}-01$ & $1.260 \mathrm{E}-01$ & $1.200 \mathrm{E}-01$ & 1.144E-01 & $1.090 \mathrm{E}-01$ \\
\hline TH229 & $6.952 E-04$ & $7.543 \mathrm{E}-04$ & $8.135 \mathrm{E}-04$ & 8.726E-04 & $9.612 \mathrm{E}-04$ & $1.109 \mathrm{E}-03$ & 1.257E-03 & 1.404E-03 \\
\hline TH230 & $1.195 \mathrm{E}-05$ & $1.264 \mathrm{E}-05$ & 1.333E-05 & $1.403 \mathrm{E}-05$ & $1.508 \mathrm{E}-05$ & 1.684E-05 & $1.861 \mathrm{E}-05$ & $2.038 \mathrm{E}-05$ \\
\hline TH231 & $1.630 \mathrm{E}-04$ & $1.630 \mathrm{E}-04$ & $1.630 \mathrm{E}-04$ & $1.630 \mathrm{E}-04$ & $1.630 \mathrm{E}-04$ & $1.630 \mathrm{E}-04$ & $1.630 \mathrm{E}-04$ & $1.630 \mathrm{E}-04$ \\
\hline TH232 & $1.440 \mathrm{E}-04$ & 1.440E-04 & $1.440 \mathrm{E}-04$ & 1.440E-04 & $1.440 \mathrm{E}-04$ & 1.440E-04 & $1.440 \mathrm{E}-04$ & $1.440 \mathrm{E}-04$ \\
\hline TH234 & 3.364E-06 & 3.364E-06 & 3.364E-06 & 3.364E-06 & 3.364E-06 & 3.364E-06 & $3.364 \mathrm{E}-06$ & $3.364 \mathrm{E}-06$ \\
\hline PA231 & $5.930 \mathrm{E}-04$ & 5.930 E- 04 & 5.930 E-04 & $5.930 \mathrm{E}-04$ & $5.930 \mathrm{E}-04$ & 5.929E-04 & $5.929 \mathrm{E}-04$ & $5.928 \mathrm{E}-04$ \\
\hline PA233 & $2.088 \mathrm{E}-03$ & $2.088 \mathrm{E}-03$ & 2.089E-03 & $2.089 \mathrm{E}-03$ & $2.089 \mathrm{E}-03$ & $2.090 \mathrm{E}-03$ & $2.091 \mathrm{E}-03$ & $2.092 E-03$ \\
\hline PA234M & 3.364E-06 & 3.364E-06 & $3.364 \mathrm{E}-06$ & $3.364 \mathrm{E}-06$ & $3.364 \mathrm{E}-06$ & 3.364E-06 & 3.364E-06 & 3.364E-06 \\
\hline PA234 & 4.373E-09 & 4.373E-09 & 4.373E-09 & $4.373 \mathrm{E}-09$ & $4.373 \mathrm{E}-09$ & 4.373E-09 & 4.373E-09 & 4.373E-09 \\
\hline U232 & $1.336 \mathrm{E}-01$ & 1.310E-01 & $1.285 \mathrm{E}-01$ & $1.261 \mathrm{E}-01$ & $1.225 \mathrm{E}-01$ & 1.167E-01 & 1.112E-01 & $\mathrm{E}-01$ \\
\hline U233 & $3.138 \mathrm{E}-01$ & $3.138 \mathrm{E}-01$ & $3.138 \mathrm{E}-01$ & $3.138 \mathrm{E}-01$ & $3.138 \mathrm{E}-01$ & 3.138E-01 & $3.138 \mathrm{E}-01$ & 3.138E-01 \\
\hline U234 & 3.849E-02 & $3.859 \mathrm{E}-02$ & $3.869 \mathrm{E}-02$ & 3.879E-02 & $3.894 \mathrm{E}-02$ & $3.918 \mathrm{E}-02$ & 3.941E-02 & $3.963 \mathrm{E}-02$ \\
\hline U235 & $1.630 \mathrm{E}-04$ & $1.630 \mathrm{E}-04$ & $1.630 \mathrm{E}-04$ & 1.630E-04 & $1.630 \mathrm{E}-04$ & $1.630 \mathrm{E}-04$ & 1.630E-04 & 1.630E-04 \\
\hline U236 & 1.892E-03 & $1.892 E-03$ & $1.892 \mathrm{E}-03$ & 1.892E-03 & $1.892 \mathrm{E}-03$ & 1.892E-03 & 1.892E-03 & 1.892E-03 \\
\hline U237 & 1.681E-06 & $1.527 \mathrm{E}-06$ & $1.387 \mathrm{E}-06$ & 1.259E-06 & $1.090 \mathrm{E}-06$ & $8.569 \mathrm{E}-07$ & 6.736E-07 & 5.295E-07 \\
\hline U238 & 3.364E-06 & 3.364E-06 & 3.364E-06 & $3.364 \mathrm{E}-06$ & 3.36 & $3.364 \mathrm{E}-06$ & 3.364E-06 & $3.364 E-06$ \\
\hline NP237 & $2.088 \mathrm{E}-03$ & 2.08 & $2.089 \mathrm{E}-03$ & $2.089 \mathrm{E}-03$ & $2.089 \mathrm{E}-03$ & 2.090E-03 & 2.091E-03 & 2.092E-03 \\
\hline PU236 & 8.347E-07 & 5.136E-07 & $3.159 \mathrm{E}-07$ & 1.944E-07 & $9.394 \mathrm{E}-08$ & $2.812 \mathrm{E}-08$ & 8.600 E-09 & 2.809E-09 \\
\hline PU237 & $0.000 \mathrm{E}+00$ & $0.000 E+00$ & $0.000 \mathrm{E}+00$ & $0.000 \mathrm{E}+00$ & $0.000 E+00$ & $0.000 E+00$ & $0.000 \mathrm{E}+00$ & $0.000 E+00$ \\
\hline PU238 & $1.836 E+01$ & $1.807 \mathrm{E}+01$ & $1.779 \mathrm{E}+01$ & $1.751 \mathrm{E}+01$ & $1.710 E+01$ & $1.644 \mathrm{E}+01$ & $1.580 \mathrm{E}+01$ & $1.519 E+01$ \\
\hline PU239 & $2.430 \mathrm{E}-02$ & $2.430 \mathrm{E}-02$ & 2.430 E-02 & $2.430 \mathrm{E}-02$ & $2.429 \mathrm{E}-02$ & $2.429 \mathrm{E}-02$ & $2.429 \mathrm{E}-02$ & $2.429 \mathrm{E}-02$ \\
\hline PU240 & $3.034 \mathrm{E}-02$ & $3.042 E-02$ & $3.049 \mathrm{E}-02$ & $3.056 \mathrm{E}-02$ & $3.065 \mathrm{E}-02$ & $3.078 E-02$ & $3.088 \mathrm{E}-02$ & $3.096 \mathrm{E}-02$ \\
\hline PU241 & $6.853 \mathrm{E}+00$ & $6.224 \mathrm{E}+00$ & $5.653 \mathrm{E}+00$ & $5.134 \mathrm{E}+00$ & $4.444 \mathrm{E}+00$ & $3.493 E+00$ & $2.746 \mathrm{E}+00$ & $2.158 \mathrm{E}+00$ \\
\hline PU242 & 3.684E-04 & $3.684 \mathrm{E}-04$ & 3.684E-04 & $3.684 \mathrm{E}-04$ & $3.684 \mathrm{E}-04$ & 3.684E-04 & $3.684 \mathrm{E}-04$ & $3.684 \mathrm{E}-04$ \\
\hline PU244 & $1.169 \mathrm{E}-10$ & $1.169 \mathrm{E}-10$ & 1.169E-10 & $1.169 \mathrm{E}-10$ & $1.169 \mathrm{E}-10$ & $1.169 \mathrm{E}-10$ & $1.169 \mathrm{E}-10$ & $1.169 \mathrm{E}-10$ \\
\hline AM241 & $4.290 \mathrm{E}-01$ & 4.486E-01 & $4.661 \mathrm{E}-01$ & $4.819 \mathrm{E}-01$ & $5.025 \mathrm{E}-01$ & $5.301 \mathrm{E}-01$ & 5.506E-01 & 5.657E-01 \\
\hline AM242M & 3.803E-04 & $3.769 \mathrm{E}-04$ & $3.734 \mathrm{E}-04$ & 3.701E-04 & $3.650 \mathrm{E}-04$ & $3.568 \mathrm{E}-04$ & $3.488 \mathrm{E}-04$ & $3.409 \mathrm{E}-04$ \\
\hline AM242 & $3.784 \mathrm{E}-04$ & $3.750 \mathrm{E}-04$ & $3.716 \mathrm{E}-04$ & 3.682E-04 & $3.632 \mathrm{E}-04$ & $3.550 \mathrm{E}-04$ & $3.470 \mathrm{E}-04$ & 3.392E-04 \\
\hline AM243 & $3.318 \mathrm{E}-03$ & 3.317E-03 & $3.317 \mathrm{E}-03$ & $3.316 \mathrm{E}-03$ & $3.315 \mathrm{E}-03$ & 3.314E-03 & 3.312E-03 & $3.311 \mathrm{E}-03$ \\
\hline CM242 & $3.134 \mathrm{E}-04$ & 3.107E-04 & 3.079E-04 & 3.051E-04 & $3.010 \mathrm{E}-04$ & $2.937 \mathrm{E}-04$ & $2.871 \mathrm{E}-04$ & $2.806 \mathrm{E}-04$ \\
\hline CM243 & $3.420 \mathrm{E}-03$ & $3.258 \mathrm{E}-03$ & $3.103 \mathrm{E}-03$ & $2.956 \mathrm{E}-03$ & $2.748 \mathrm{E}-03$ & $2.433 \mathrm{E}-03$ & $2.155 \mathrm{E}-03$ & $1.908 \mathrm{E}-03$ \\
\hline CM244 & $4.188 \mathrm{E}-01$ & $3.880 \mathrm{E}-01$ & $3.594 \mathrm{E}-01$ & $3.329 \mathrm{E}-01$ & $2.968 \mathrm{E}-01$ & $2.451 E-01$ & 2.024E-01 & $1.671 \mathrm{E}-01$ \\
\hline CM245 & 1.161E-04 & 1.161E-04 & $1.160 \mathrm{E}-04$ & $1.160 \mathrm{E}-04$ & $1.160 \mathrm{E}-04$ & $1.159 \mathrm{E}-04$ & 1.159E-04 & $1.158 \mathrm{E}-04$ \\
\hline CM246 & $1.700 \mathrm{E}-05$ & 1.699E-05 & $1.699 \mathrm{E}-05$ & $1.698 \mathrm{E}-05$ & 1.697E-05 & $1.696 \mathrm{E}-05$ & $1.695 \mathrm{E}-05$ & $1.694 \mathrm{E}-05$ \\
\hline CM247 & $6.571 \mathrm{E}-11$ & $6.571 \mathrm{E}-11$ & $6.571 \mathrm{E}-11$ & $6.571 \mathrm{E}-11$ & $6.571 E-11$ & $6.571 \mathrm{E}-11$ & $6.571 \mathrm{E}-11$ & $6.571 E-11$ \\
\hline Subtotal & $1.129 \mathrm{E}+03$ & $1.074 E+03$ & $1.023 E+03$ & $9.749 E+02$ & $9.071 \mathrm{E}+02$ & $8.055 E+02$ & $7.159 \mathrm{E}+02$ & $6.368 \mathrm{E}+02$ \\
\hline TOTAL & $1.129 E+03$ & $1.074 E+03$ & $1.023 E+03$ & $9.749 \mathrm{E}+02$ & $9.072 E+02$ & $8.055 \mathrm{E}+02$ & $7.159 E+02$ & $6.367 E+02$ \\
\hline
\end{tabular}


Table 18. Heat generation calculated for a Type II element in Core 1 and in Core 2 for July 2005. ${ }^{\text {a }}$

\begin{tabular}{|c|c|c|c|c|c|c|c|}
\hline Isotope & $\begin{array}{l}\text { Specific } \\
\text { Activity } \\
(\mathrm{Ci} / \mathrm{g}) \\
\end{array}$ & $\begin{array}{c}\text { Specific } \\
\text { Heat } \\
(\mathrm{W} / \mathrm{gm}) \\
\end{array}$ & $\begin{array}{l}\text { Specific Heat } \\
\text { per Curie } \\
(\mathrm{W} / \mathrm{Ci})\end{array}$ & $\begin{array}{c}\text { Peach Bottom } \\
\text { Core } 1 \text { Curies } \\
7 / 1 / 2005 \\
\end{array}$ & $\begin{array}{l}\text { Peach Bottom } \\
\text { Core } 1 \text { Watts }\end{array}$ & $\begin{array}{c}\text { Peach Bottom } \\
\text { Core } 2 \text { Curies } \\
7 / 1 / 2005 \\
\end{array}$ & $\begin{array}{l}\text { Peach Bottom } \\
\text { Core } 2 \text { Watts }\end{array}$ \\
\hline $\mathrm{H}-3$ & $9.65 \mathrm{E}+03$ & $3.25 \mathrm{E}-01$ & $3.37 \mathrm{E}-05$ & $4.660 \mathrm{E}-01$ & $1.57 \mathrm{E}-05$ & $1.147 \mathrm{E}+00$ & $3.86 \mathrm{E}-05$ \\
\hline BE-10 & $2.24 \mathrm{E}-02$ & $2.68 \mathrm{E}-05$ & $1.20 \mathrm{E}-03$ & 4.624E-05 & $5.55 \mathrm{E}-08$ & $1.211 \mathrm{E}-04$ & $1.45 \mathrm{E}-07$ \\
\hline C-14 & $4.46 \mathrm{E}+00$ & $1.31 \mathrm{E}-03$ & $2.93 \mathrm{E}-04$ & $2.940 \mathrm{E}-03$ & 8.62E-07 & $8.335 \mathrm{E}-03$ & $2.44 \mathrm{E}-06$ \\
\hline CL-36 & $3.30 \mathrm{E}-02$ & $4.83 \mathrm{E}-05$ & $1.46 \mathrm{E}-03$ & $8.320 \mathrm{E}-05$ & $1.22 \mathrm{E}-07$ & $2.122 \mathrm{E}-04$ & $3.10 \mathrm{E}-07$ \\
\hline CR-51 & $9.24 \mathrm{E}+04$ & $1.98 \mathrm{E}+01$ & $2.14 \mathrm{E}-04$ & $0.000 \mathrm{E}+00$ & $0.00 \mathrm{E}+00$ & $0.000 \mathrm{E}+00$ & $0.00 \mathrm{E}+00$ \\
\hline MN-54 & $7.74 \mathrm{E}+03$ & $3.86 \mathrm{E}+01$ & $4.98 \mathrm{E}-03$ & $2.946 \mathrm{E}-14$ & $1.47 \mathrm{E}-16$ & $3.329 \mathrm{E}-12$ & $1.66 \mathrm{E}-14$ \\
\hline $\mathrm{Fe}-55$ & $2.50 \mathrm{E}+03$ & $3.44 \mathrm{E}+00$ & $1.38 \mathrm{E}-03$ & $4.514 \mathrm{E}-05$ & $6.21 \mathrm{E}-08$ & $3.836 \mathrm{E}-04$ & $5.27 \mathrm{E}-07$ \\
\hline FE-59 & $4.92 \mathrm{E}+04$ & $4.59 \mathrm{E}+02$ & $9.32 \mathrm{E}-03$ & $2.165 \mathrm{E}-89$ & $2.02 \mathrm{E}-91$ & $0.000 \mathrm{E}+00$ & $0.00 \mathrm{E}+00$ \\
\hline CO-60 & $1.13 \mathrm{E}+03$ & $1.74 \mathrm{E}+01$ & $1.54 \mathrm{E}-02$ & $5.236 \mathrm{E}-02$ & 8.07E-04 & $2.354 \mathrm{E}-01$ & $3.63 \mathrm{E}-03$ \\
\hline NI-59 & $7.58 \mathrm{E}-02$ & $4.82 \mathrm{E}-04$ & $6.37 \mathrm{E}-03$ & $1.141 \mathrm{E}-04$ & $7.26 \mathrm{E}-07$ & $2.795 \mathrm{E}-04$ & $1.78 \mathrm{E}-06$ \\
\hline NI-63 & $6.17 \mathrm{E}+01$ & $2.45 \mathrm{E}-02$ & $3.97 \mathrm{E}-04$ & $1.104 \mathrm{E}-02$ & $4.38 \mathrm{E}-06$ & $2.932 \mathrm{E}-02$ & $1.16 \mathrm{E}-05$ \\
\hline ZN-65 & $8.24 \mathrm{E}+03$ & $2.89 \mathrm{E}+01$ & $3.51 \mathrm{E}-03$ & $4.257 \mathrm{E}-18$ & $1.49 \mathrm{E}-20$ & $1.493 \mathrm{E}-15$ & $5.23 \mathrm{E}-18$ \\
\hline SE-79 & $6.97 \mathrm{E}-02$ & $1.73 \mathrm{E}-05$ & $2.49 \mathrm{E}-04$ & $1.054 \mathrm{E}-03$ & 2.62E-07 & $2.436 \mathrm{E}-03$ & $6.06 \mathrm{E}-07$ \\
\hline KR-85 & $3.93 \mathrm{E}+02$ & $5.88 \mathrm{E}-01$ & $1.50 \mathrm{E}-03$ & $2.848 \mathrm{E}+00$ & $4.26 \mathrm{E}-03$ & $7.974 \mathrm{E}+00$ & $1.19 \mathrm{E}-02$ \\
\hline RB-87 & $8.75 \mathrm{E}-08$ & 7.32E-11 & $8.36 \mathrm{E}-04$ & $6.745 \mathrm{E}-08$ & $5.64 \mathrm{E}-11$ & $1.400 \mathrm{E}-07$ & $1.17 \mathrm{E}-10$ \\
\hline SR-89 & $2.91 \mathrm{E}+04$ & $1.01 \mathrm{E}+02$ & $3.46 \mathrm{E}-03$ & $6.173 \mathrm{E}-75$ & $2.13 \mathrm{E}-77$ & $0.000 \mathrm{E}+00$ & $0.00 \mathrm{E}+00$ \\
\hline SR-90 & $1.37 \mathrm{E}+02$ & $1.59 \mathrm{E}-01$ & $1.16 \mathrm{E}-03$ & $9.652 \mathrm{E}+01$ & $1.12 \mathrm{E}-01$ & $2.144 \mathrm{E}+02$ & $2.49 \mathrm{E}-01$ \\
\hline Y-90 & $5.44 \mathrm{E}+05$ & $3.02 \mathrm{E}+03$ & $5.54 \mathrm{E}-03$ & $9.654 \mathrm{E}+01$ & $5.35 \mathrm{E}-01$ & $2.144 \mathrm{E}+02$ & $1.19 \mathrm{E}+00$ \\
\hline Y-91 & $2.45 \mathrm{E}+04$ & $8.81 \mathrm{E}+01$ & $3.59 \mathrm{E}-03$ & $3.328 \mathrm{E}-64$ & $1.20 \mathrm{E}-66$ & $1.248 \mathrm{E}-54$ & $4.48 \mathrm{E}-57$ \\
\hline ZR-93 & $2.52 \mathrm{E}-03$ & $2.92 \mathrm{E}-07$ & $1.16 \mathrm{E}-04$ & $4.953 \mathrm{E}-03$ & $5.76 \mathrm{E}-07$ & $9.829 \mathrm{E}-03$ & $1.14 \mathrm{E}-06$ \\
\hline ZR-95 & $2.15 \mathrm{E}+04$ & $1.09 \mathrm{E}+02$ & $5.07 \mathrm{E}-03$ & $1.997 \mathrm{E}-58$ & $1.01 \mathrm{E}-60$ & $1.110 \mathrm{E}-49$ & $5.62 \mathrm{E}-52$ \\
\hline NB-93M & $2.83 \mathrm{E}+02$ & $5.01 \mathrm{E}-02$ & $1.77 \mathrm{E}-04$ & $3.990 \mathrm{E}-03$ & 7.07E-07 & $7.587 \mathrm{E}-03$ & $1.34 \mathrm{E}-06$ \\
\hline NB-94 & $1.87 \mathrm{E}-01$ & $1.91 \mathrm{E}-03$ & $1.02 \mathrm{E}-02$ & $3.852 \mathrm{E}-05$ & $3.93 \mathrm{E}-07$ & $9.847 \mathrm{E}-05$ & $1.00 \mathrm{E}-06$ \\
\hline NB-95 & $3.91 \mathrm{E}+04$ & $1.88 \mathrm{E}+02$ & $4.80 \mathrm{E}-03$ & 4.434E-58 & $2.13 \mathrm{E}-60$ & $2.465 \mathrm{E}-49$ & $1.18 \mathrm{E}-51$ \\
\hline $\mathrm{Nb}-95 \mathrm{~m}$ & $3.81 \mathrm{E}+05$ & $5.29 \mathrm{E}+02$ & $1.39 \mathrm{E}-03$ & $1.482 \mathrm{E}-60$ & $2.06 \mathrm{E}-63$ & $8.237 \mathrm{E}-52$ & $1.14 \mathrm{E}-54$ \\
\hline MO-93 & $1.10 \mathrm{E}+00$ & $1.03 \mathrm{E}-04$ & $9.34 \mathrm{E}-05$ & $1.254 \mathrm{E}-06$ & $1.17 \mathrm{E}-10$ & $3.285 \mathrm{E}-06$ & $3.07 \mathrm{E}-10$ \\
\hline TC-99 & $1.70 \mathrm{E}-02$ & $8.50 \mathrm{E}-06$ & $5.01 \mathrm{E}-04$ & $3.116 \mathrm{E}-02$ & $1.56 \mathrm{E}-05$ & $5.555 \mathrm{E}-02$ & $2.79 \mathrm{E}-05$ \\
\hline Ru-103 & $3.23 \mathrm{E}+04$ & $1.08 \mathrm{E}+02$ & $3.35 \mathrm{E}-03$ & $1.123 \mathrm{E}-94$ & $3.76 \mathrm{E}-97$ & $0.000 \mathrm{E}+00$ & $0.00 \mathrm{E}+00$ \\
\hline Ru 106 & $3.35 \mathrm{E}+03$ & $1.99 \mathrm{E}-01$ & $5.95 \mathrm{E}-05$ & $5.343 \mathrm{E}-09$ & $3.18 \mathrm{E}-13$ & $2.329 \mathrm{E}-07$ & $1.39 \mathrm{E}-11$ \\
\hline $\mathrm{Rh}-103 \mathrm{~m}$ & $3.26 \mathrm{E}+07$ & $7.49 \mathrm{E}+03$ & $2.30 \mathrm{E}-04$ & $1.012 \mathrm{E}-94$ & 2.33E-98 & $0.000 \mathrm{E}+00$ & $0.00 \mathrm{E}+00$ \\
\hline Rh-106 & $3.56 \mathrm{E}+09$ & $3.42 \mathrm{E}+07$ & $9.59 \mathrm{E}-03$ & $5.343 \mathrm{E}-09$ & $5.13 \mathrm{E}-11$ & $2.329 \mathrm{E}-07$ & 2.23E-09 \\
\hline PD-107 & $5.15 \mathrm{E}-04$ & $3.05 \mathrm{E}-08$ & $5.93 \mathrm{E}-05$ & $3.702 \mathrm{E}-05$ & 2.19E-09 & $7.625 \mathrm{E}-05$ & $4.52 \mathrm{E}-09$ \\
\hline Ag-110 & $4.17 \mathrm{E}+09$ & $3.00 \mathrm{E}+07$ & $7.18 \mathrm{E}-03$ & $1.955 \mathrm{E}-18$ & $1.40 \mathrm{E}-20$ & $1.059 \mathrm{E}-15$ & 7.61E-18 \\
\hline Ag-110m & $4.75 \mathrm{E}+03$ & $7.94 \mathrm{E}+01$ & $1.67 \mathrm{E}-02$ & $1.469 \mathrm{E}-16$ & $2.45 \mathrm{E}-18$ & $7.963 \mathrm{E}-14$ & $1.33 \mathrm{E}-15$ \\
\hline Ag-111 & $1.58 \mathrm{E}+05$ & $3.54 \mathrm{E}+02$ & $2.24 \mathrm{E}-03$ & $0.000 \mathrm{E}+00$ & $0.00 \mathrm{E}+00$ & $0.000 \mathrm{E}+00$ & $0.00 \mathrm{E}+00$ \\
\hline Cd-113m & $2.17 \mathrm{E}+02$ & $3.65 \mathrm{E}-01$ & $1.68 \mathrm{E}-03$ & $5.353 \mathrm{E}-03$ & $9.01 \mathrm{E}-06$ & $1.414 \mathrm{E}-02$ & $2.38 \mathrm{E}-05$ \\
\hline Cd-113 & $0.00 \mathrm{E}+00$ & $0.00 \mathrm{E}+00$ & $0.00 \mathrm{E}+00$ & $0.000 \mathrm{E}+00$ & $0.00 \mathrm{E}+00$ & $0.000 \mathrm{E}+00$ & $0.00 \mathrm{E}+00$ \\
\hline Cd-115m & $2.55 \mathrm{E}+04$ & $9.50 \mathrm{E}+01$ & $3.73 \mathrm{E}-03$ & $9.536 \mathrm{E}-89$ & $3.56 \mathrm{E}-91$ & $0.000 \mathrm{E}+00$ & $0.00 \mathrm{E}+00$ \\
\hline In-114 & $1.38 \mathrm{E}+09$ & $6.32 \mathrm{E}+06$ & $4.59 \mathrm{E}-03$ & $5.813 \mathrm{E}-81$ & $2.67 \mathrm{E}-83$ & $0.000 \mathrm{E}+00$ & $0.00 \mathrm{E}+00$ \\
\hline In-114m & $2.31 \mathrm{E}+04$ & $3.26 \mathrm{E}+01$ & $1.41 \mathrm{E}-03$ & $6.074 \mathrm{E}-81$ & $8.56 \mathrm{E}-84$ & $0.000 \mathrm{E}+00$ & $0.00 \mathrm{E}+00$ \\
\hline In- $115 \mathrm{~m}$ & $6.34 \mathrm{E}+06$ & $1.26 \mathrm{E}+04$ & $1.99 \mathrm{E}-03$ & 6.666E-93 & $1.33 \mathrm{E}-95$ & $0.000 \mathrm{E}+00$ & $0.00 \mathrm{E}+00$ \\
\hline
\end{tabular}


Table 18. (continued).

\begin{tabular}{|c|c|c|c|c|c|c|c|}
\hline Isotope & $\begin{array}{l}\text { Specific } \\
\text { Activity } \\
(\mathrm{Ci} / \mathrm{g})\end{array}$ & $\begin{array}{l}\text { Specific } \\
\text { Heat } \\
(\mathrm{W} / \mathrm{gm})\end{array}$ & $\begin{array}{l}\text { Specific Heat } \\
\text { per Curie } \\
(\mathrm{W} / \mathrm{Ci})\end{array}$ & $\begin{array}{c}\text { Peach Bottom } \\
\text { Core } 1 \text { Curies } \\
7 / 1 / 2005 \\
\end{array}$ & $\begin{array}{l}\text { Peach Bottom } \\
\text { Core } 1 \text { Watts }\end{array}$ & $\begin{array}{c}\text { Peach Bottom } \\
\text { Core } 2 \text { Curies } \\
7 / 1 / 2005\end{array}$ & $\begin{array}{c}\text { Peach Bottom } \\
\text { Core } 2 \text { Watts }\end{array}$ \\
\hline $\mathrm{Sn}-119 \mathrm{~m}$ & $4.48 \mathrm{E}+03$ & $2.32 \mathrm{E}+00$ & $5.17 \mathrm{E}-04$ & $1.830 \mathrm{E}-17$ & $9.46 \mathrm{E}-21$ & $4.930 \mathrm{E}-15$ & $2.55 \mathrm{E}-18$ \\
\hline $\mathrm{Sn}-121 \mathrm{~m}$ & $5.91 \mathrm{E}+01$ & $1.19 \mathrm{E}-01$ & $2.00 \mathrm{E}-03$ & $1.563 \mathrm{E}-04$ & $3.13 \mathrm{E}-07$ & 4.433E-04 & 8.88E-07 \\
\hline $\mathrm{Sn}-123$ & $8.22 \mathrm{E}+03$ & $2.57 \mathrm{E}+01$ & $3.12 \mathrm{E}-03$ & $1.768 \mathrm{E}-30$ & $5.52 \mathrm{E}-33$ & $4.703 \mathrm{E}-26$ & $1.47 \mathrm{E}-28$ \\
\hline $\mathrm{Sn}-125$ & $1.08 \mathrm{E}+05$ & $7.18 \mathrm{E}+02$ & $6.63 \mathrm{E}-03$ & $0.000 \mathrm{E}+00$ & $0.00 \mathrm{E}+00$ & $0.000 \mathrm{E}+00$ & $0.00 \mathrm{E}+00$ \\
\hline Sn-126 & $2.84 \mathrm{E}-02$ & $3.54 \mathrm{E}-05$ & $1.25 \mathrm{E}-03$ & $9.797 \mathrm{E}-04$ & $1.22 \mathrm{E}-06$ & $2.398 \mathrm{E}-03$ & $2.99 \mathrm{E}-06$ \\
\hline $\mathrm{Sb}-124$ & $1.75 \mathrm{E}+04$ & $2.33 \mathrm{E}+02$ & $1.33 \mathrm{E}-02$ & $1.053 \mathrm{E}-65$ & $1.40 \mathrm{E}-67$ & $5.564 \mathrm{E}-56$ & 7.39E-58 \\
\hline $\mathrm{Sb}-125$ & $1.03 \mathrm{E}+03$ & $3.23 \mathrm{E}+00$ & $3.13 \mathrm{E}-03$ & $1.933 \mathrm{E}-03$ & $6.04 \mathrm{E}-06$ & $1.407 \mathrm{E}-02$ & $4.40 \mathrm{E}-05$ \\
\hline $\mathrm{Sb}-126$ & $8.36 \mathrm{E}+04$ & $1.55 \mathrm{E}+03$ & $1.85 \mathrm{E}-02$ & $1.372 \mathrm{E}-04$ & $2.54 \mathrm{E}-06$ & $3.357 \mathrm{E}-04$ & $6.20 \mathrm{E}-06$ \\
\hline $\mathrm{Sb}-126 \mathrm{~m}$ & $7.86 \mathrm{E}+07$ & $1.00 \mathrm{E}+06$ & $1.27 \mathrm{E}-02$ & $9.797 \mathrm{E}-04$ & $1.25 \mathrm{E}-05$ & $2.398 \mathrm{E}-03$ & $3.06 \mathrm{E}-05$ \\
\hline TE-123m & $8.87 \mathrm{E}+03$ & $1.29 \mathrm{E}+01$ & $1.46 \mathrm{E}-03$ & $1.568 \mathrm{E}-35$ & $2.28 \mathrm{E}-38$ & $4.354 \mathrm{E}-30$ & $6.34 \mathrm{E}-33$ \\
\hline $\mathrm{Te}-125 \mathrm{~m}$ & $1.80 \mathrm{E}+04$ & $1.51 \mathrm{E}+01$ & $8.41 \mathrm{E}-04$ & 4.717E-04 & $3.96 \mathrm{E}-07$ & $3.432 \mathrm{E}-03$ & $2.88 \mathrm{E}-06$ \\
\hline TE-127 & $2.64 \mathrm{E}+06$ & $3.57 \mathrm{E}+03$ & $1.35 \mathrm{E}-03$ & $2.157 \mathrm{E}-35$ & $2.91 \mathrm{E}-38$ & $4.848 \mathrm{E}-30$ & $6.54 \mathrm{E}-33$ \\
\hline TE-127M & $9.44 \mathrm{E}+03$ & $5.08 \mathrm{E}+00$ & $5.38 \mathrm{E}-04$ & $2.203 \mathrm{E}-35$ & $1.19 \mathrm{E}-38$ & $4.949 \mathrm{E}-30$ & $2.66 \mathrm{E}-33$ \\
\hline TE-129 & $2.10 \mathrm{E}+07$ & $7.49 E+04$ & $3.57 \mathrm{E}-03$ & $0.000 \mathrm{E}+00$ & $0.00 \mathrm{E}+00$ & $0.000 \mathrm{E}+00$ & $0.00 \mathrm{E}+00$ \\
\hline TE-129M & $3.01 \mathrm{E}+04$ & $5.28 \mathrm{E}+01$ & $1.75 \mathrm{E}-03$ & $0.000 \mathrm{E}+00$ & $0.00 \mathrm{E}+00$ & $0.000 \mathrm{E}+00$ & $0.00 \mathrm{E}+00$ \\
\hline I-129 & $1.77 \mathrm{E}-04$ & $8.17 \mathrm{E}-08$ & $4.63 \mathrm{E}-04$ & $5.714 \mathrm{E}-05$ & $2.64 \mathrm{E}-08$ & $1.251 \mathrm{E}-04$ & 5.79E-08 \\
\hline I-131 & $1.24 \mathrm{E}+05$ & $4.21 \mathrm{E}+02$ & $3.40 \mathrm{E}-03$ & $0.000 \mathrm{E}+00$ & $0.00 \mathrm{E}+00$ & $0.000 \mathrm{E}+00$ & $0.00 \mathrm{E}+00$ \\
\hline $\mathrm{XE}-131 \mathrm{M}$ & $8.38 \mathrm{E}+04$ & $8.06 \mathrm{E}+01$ & $9.62 \mathrm{E}-04$ & $0.000 \mathrm{E}+00$ & $0.00 \mathrm{E}+00$ & $0.000 \mathrm{E}+00$ & $0.00 \mathrm{E}+00$ \\
\hline XE-133 & $1.87 \mathrm{E}+05$ & $2.01 \mathrm{E}+02$ & $1.07 \mathrm{E}-03$ & $0.000 \mathrm{E}+00$ & $0.00 \mathrm{E}+00$ & $0.000 \mathrm{E}+00$ & $0.00 \mathrm{E}+00$ \\
\hline Cs-134 & $1.29 \mathrm{E}+03$ & $1.32 \mathrm{E}+01$ & $1.02 \mathrm{E}-02$ & 1.099E-03 & $1.12 \mathrm{E}-05$ & $2.585 \mathrm{E}-02$ & $2.63 \mathrm{E}-04$ \\
\hline CS-135 & $1.15 \mathrm{E}-03$ & $3.84 \mathrm{E}-07$ & $3.34 \mathrm{E}-04$ & $1.922 \mathrm{E}-03$ & $6.41 \mathrm{E}-07$ & $3.150 \mathrm{E}-03$ & $1.05 \mathrm{E}-06$ \\
\hline Cs-136 & $7.33 E+04$ & $1.00 \mathrm{E}+03$ & $1.36 \mathrm{E}-02$ & $0.000 \mathrm{E}+00$ & $0.00 \mathrm{E}+00$ & $0.000 \mathrm{E}+00$ & $0.00 \mathrm{E}+00$ \\
\hline Cs-137 & $8.70 \mathrm{E}+01$ & $9.62 \mathrm{E}-02$ & $1.11 \mathrm{E}-03$ & $1.026 \mathrm{E}+02$ & $1.13 \mathrm{E}-01$ & $2.262 \mathrm{E}+02$ & $2.50 \mathrm{E}-01$ \\
\hline Ba-136M & $2.69 \mathrm{E}+11$ & $3.26 \mathrm{E}+09$ & $1.21 \mathrm{E}-02$ & $0.000 \mathrm{E}+00$ & $0.00 \mathrm{E}+00$ & $0.000 \mathrm{E}+00$ & $0.00 \mathrm{E}+00$ \\
\hline Ba-137M & $5.38 \mathrm{E}+08$ & $2.11 \mathrm{E}+06$ & $3.93 \mathrm{E}-03$ & $9.706 \mathrm{E}+01$ & $3.81 \mathrm{E}-01$ & $2.139 \mathrm{E}+02$ & $8.40 \mathrm{E}-01$ \\
\hline Ba-140 & $7.30 \mathrm{E}+04$ & $2.04 \mathrm{E}+02$ & $2.79 \mathrm{E}-03$ & $0.000 \mathrm{E}+00$ & $0.00 \mathrm{E}+00$ & $0.000 \mathrm{E}+00$ & $0.00 \mathrm{E}+00$ \\
\hline La-140 & $5.57 \mathrm{E}+05$ & $9.33 \mathrm{E}+03$ & $1.68 \mathrm{E}-02$ & $0.000 \mathrm{E}+00$ & $0.00 \mathrm{E}+00$ & $0.000 \mathrm{E}+00$ & $0.00 \mathrm{E}+00$ \\
\hline Ce-141 & $2.85 \mathrm{E}+04$ & $4.17 \mathrm{E}+01$ & $1.46 \mathrm{E}-03$ & $0.000 \mathrm{E}+00$ & $0.00 \mathrm{E}+00$ & $0.000 \mathrm{E}+00$ & $0.00 \mathrm{E}+00$ \\
\hline Ce-142 & $2.40 \mathrm{E}-08$ & $0.00 \mathrm{E}+00$ & $0.00 \mathrm{E}+00$ & $6.635 \mathrm{E}-08$ & $0.00 \mathrm{E}+00$ & $1.333 \mathrm{E}-07$ & $0.00 \mathrm{E}+00$ \\
\hline CE-144 & $3.19 \mathrm{E}+03$ & $2.12 \mathrm{E}+00$ & $6.63 \mathrm{E}-04$ & $5.110 \mathrm{E}-11$ & $3.39 \mathrm{E}-14$ & 5.580E-09 & $3.70 \mathrm{E}-12$ \\
\hline $\operatorname{Pr}-143$ & $6.73 E+04$ & $1.26 \mathrm{E}+02$ & $1.86 \mathrm{E}-03$ & $0.000 \mathrm{E}+00$ & $0.00 \mathrm{E}+00$ & $0.000 \mathrm{E}+00$ & $0.00 \mathrm{E}+00$ \\
\hline PR-144 & $7.56 \mathrm{E}+07$ & $5.56 \mathrm{E}+05$ & $7.35 \mathrm{E}-03$ & $5.110 \mathrm{E}-11$ & $3.76 \mathrm{E}-13$ & $5.580 \mathrm{E}-09$ & $4.10 \mathrm{E}-11$ \\
\hline PR-144M & $1.82 \mathrm{E}+08$ & $6.21 \mathrm{E}+04$ & $3.42 \mathrm{E}-04$ & $6.132 \mathrm{E}-13$ & $2.10 \mathrm{E}-16$ & $6.696 \mathrm{E}-11$ & $2.29 \mathrm{E}-14$ \\
\hline Nd-144 & $1.18 \mathrm{E}-12$ & $0.00 \mathrm{E}+00$ & $0.00 \mathrm{E}+00$ & $3.274 \mathrm{E}-12$ & $0.00 \mathrm{E}+00$ & $7.442 \mathrm{E}-12$ & $0.00 \mathrm{E}+00$ \\
\hline $\mathrm{Nd}-147$ & $8.03 \mathrm{E}+04$ & $1.94 \mathrm{E}+02$ & $2.41 \mathrm{E}-03$ & $0.000 \mathrm{E}+00$ & $0.00 \mathrm{E}+00$ & $0.000 \mathrm{E}+00$ & $0.00 \mathrm{E}+00$ \\
\hline PM-145 & $1.39 \mathrm{E}+02$ & $3.55 \mathrm{E}-02$ & $2.55 \mathrm{E}-04$ & $1.130 \mathrm{E}-05$ & $2.88 \mathrm{E}-09$ & $3.434 \mathrm{E}-05$ & $8.76 \mathrm{E}-09$ \\
\hline PM-147 & $9.27 \mathrm{E}+02$ & $3.33 \mathrm{E}-01$ & $3.59 \mathrm{E}-04$ & $4.137 \mathrm{E}-02$ & $1.48 \mathrm{E}-05$ & $1.482 \mathrm{E}-01$ & $5.32 \mathrm{E}-05$ \\
\hline PM-148M & $2.14 \mathrm{E}+04$ & $2.71 \mathrm{E}+02$ & $1.27 \mathrm{E}-02$ & $2.601 \mathrm{E}-93$ & $3.30 \mathrm{E}-95$ & $0.000 \mathrm{E}+00$ & $0.00 \mathrm{E}+00$ \\
\hline PM-148 & $1.64 \mathrm{E}+05$ & $1.27 \mathrm{E}+03$ & $7.70 \mathrm{E}-03$ & $1.465 \mathrm{E}-94$ & $1.13 \mathrm{E}-96$ & $0.000 \mathrm{E}+00$ & $0.00 \mathrm{E}+00$ \\
\hline SM-145 & $2.65 \mathrm{E}+03$ & $1.46 \mathrm{E}+00$ & $5.53 \mathrm{E}-04$ & $1.170 \mathrm{E}-15$ & $6.47 \mathrm{E}-19$ & $9.382 \mathrm{E}-14$ & $5.19 \mathrm{E}-17$ \\
\hline SM-147 & $2.27 \mathrm{E}-08$ & $3.11 \mathrm{E}-10$ & $1.37 \mathrm{E}-02$ & $1.732 \mathrm{E}-08$ & $2.37 \mathrm{E}-10$ & $2.064 \mathrm{E}-08$ & $2.83 \mathrm{E}-10$ \\
\hline
\end{tabular}


Table 18. (continued).

\begin{tabular}{|c|c|c|c|c|c|c|c|}
\hline Isotope & $\begin{array}{l}\text { Specific } \\
\text { Activity } \\
(\mathrm{Ci} / \mathrm{g})\end{array}$ & $\begin{array}{l}\text { Specific } \\
\text { Heat } \\
(\mathrm{W} / \mathrm{gm})\end{array}$ & $\begin{array}{l}\text { Specific Heat } \\
\text { per Curie } \\
(\mathrm{W} / \mathrm{Ci})\end{array}$ & $\begin{array}{c}\text { Peach Bottom } \\
\text { Core } 1 \text { Curies } \\
7 / 1 / 2005\end{array}$ & $\begin{array}{l}\text { Peach Bottom } \\
\text { Core } 1 \text { Watts }\end{array}$ & $\begin{array}{c}\text { Peach Bottom } \\
\text { Core } 2 \text { Curies } \\
7 / 1 / 2005\end{array}$ & $\begin{array}{l}\text { Peach Bottom } \\
\text { Core } 2 \text { Watts }\end{array}$ \\
\hline SM-151 & $2.63 \mathrm{E}+01$ & $3.09 \mathrm{E}-03$ & $1.17 \mathrm{E}-04$ & $1.682 \mathrm{E}+00$ & $1.97 \mathrm{E}-04$ & $1.737 \mathrm{E}+00$ & $2.04 \mathrm{E}-04$ \\
\hline Eu-152 & $1.73 \mathrm{E}+02$ & $1.31 \mathrm{E}+00$ & $7.58 \mathrm{E}-03$ & $2.267 \mathrm{E}-02$ & $1.72 \mathrm{E}-04$ & $2.059 \mathrm{E}-02$ & $1.56 \mathrm{E}-04$ \\
\hline Eu-154 & $2.70 \mathrm{E}+02$ & $2.42 \mathrm{E}+00$ & $8.95 \mathrm{E}-03$ & $3.488 \mathrm{E}-01$ & $3.12 \mathrm{E}-03$ & $2.756 \mathrm{E}+00$ & $2.47 \mathrm{E}-02$ \\
\hline Eu-155 & $4.65 \mathrm{E}+02$ & $3.38 \mathrm{E}-01$ & $7.27 \mathrm{E}-04$ & $3.471 \mathrm{E}-02$ & $2.52 \mathrm{E}-05$ & $2.583 \mathrm{E}-01$ & $1.88 \mathrm{E}-04$ \\
\hline Eu-156 & $5.52 \mathrm{E}+04$ & $5.69 \mathrm{E}+02$ & $1.03 \mathrm{E}-02$ & $0.000 \mathrm{E}+00$ & $0.00 \mathrm{E}+00$ & $0.000 \mathrm{E}+00$ & $0.00 \mathrm{E}+00$ \\
\hline Gd-153 & $3.53 \mathrm{E}+03$ & $3.04 \mathrm{E}+00$ & 8.62E-04 & $1.805 \mathrm{E}-17$ & $1.56 \mathrm{E}-20$ & $3.544 \mathrm{E}-15$ & $3.05 \mathrm{E}-18$ \\
\hline Tb-160 & $1.13 \mathrm{E}+04$ & $9.20 \mathrm{E}+01$ & $8.15 \mathrm{E}-03$ & $7.910 \mathrm{E}-55$ & $6.44 \mathrm{E}-57$ & $6.807 \mathrm{E}-47$ & $5.54 \mathrm{E}-49$ \\
\hline TL-206 & $2.18 \mathrm{E}+08$ & $1.97 \mathrm{E}+06$ & $9.03 \mathrm{E}-03$ & $5.012 \mathrm{E}-10$ & $4.53 \mathrm{E}-12$ & $1.313 \mathrm{E}-09$ & $1.19 \mathrm{E}-11$ \\
\hline TL-207 & $1.91 \mathrm{E}+08$ & $5.60 \mathrm{E}+05$ & $2.94 \mathrm{E}-03$ & $2.530 \mathrm{E}-04$ & $7.43 \mathrm{E}-07$ & $3.813 \mathrm{E}-04$ & $1.12 \mathrm{E}-06$ \\
\hline TL-208 & $2.95 \mathrm{E}+08$ & $6.93 \mathrm{E}+06$ & $2.35 \mathrm{E}-02$ & $1.027 \mathrm{E}-02$ & $2.42 \mathrm{E}-04$ & 4.534E-02 & $1.07 \mathrm{E}-03$ \\
\hline $\mathrm{Pb}-210$ & $7.64 \mathrm{E}+01$ & $1.77 \mathrm{E}-02$ & $2.32 \mathrm{E}-04$ & $3.543 \mathrm{E}-08$ & $8.21 \mathrm{E}-12$ & $5.368 \mathrm{E}-08$ & $1.24 \mathrm{E}-11$ \\
\hline $\mathrm{Pb}-211$ & $2.47 \mathrm{E}+07$ & $7.40 \mathrm{E}+04$ & $3.00 \mathrm{E}-03$ & $2.537 \mathrm{E}-04$ & 7.60E-07 & $3.823 \mathrm{E}-04$ & $1.15 \mathrm{E}-06$ \\
\hline $\mathrm{Pb}-212$ & $1.39 \mathrm{E}+06$ & $2.65 \mathrm{E}+03$ & $1.90 \mathrm{E}-03$ & $2.858 \mathrm{E}-02$ & $5.44 \mathrm{E}-05$ & $1.262 \mathrm{E}-01$ & $2.40 \mathrm{E}-04$ \\
\hline Bi-211 & $4.19 \mathrm{E}+08$ & $1.67 \mathrm{E}+07$ & $3.99 \mathrm{E}-02$ & $2.537 \mathrm{E}-04$ & $1.01 \mathrm{E}-05$ & $3.823 \mathrm{E}-04$ & $1.52 \mathrm{E}-05$ \\
\hline Bi-212 & $1.47 \mathrm{E}+07$ & $2.49 \mathrm{E}+05$ & $1.70 \mathrm{E}-02$ & $2.858 \mathrm{E}-02$ & $4.86 \mathrm{E}-04$ & $1.262 \mathrm{E}-01$ & $2.15 \mathrm{E}-03$ \\
\hline Po-212 & $1.77 \mathrm{E}+17$ & $9.41 \mathrm{E}+15$ & $5.30 \mathrm{E}-02$ & $1.831 \mathrm{E}-02$ & $9.70 \mathrm{E}-04$ & $8.084 \mathrm{E}-02$ & $4.28 \mathrm{E}-03$ \\
\hline Po-215 & $2.95 \mathrm{E}+13$ & $1.32 \mathrm{E}+12$ & 4.47E-02 & $2.537 \mathrm{E}-04$ & $1.13 \mathrm{E}-05$ & $3.823 \mathrm{E}-04$ & $1.71 \mathrm{E}-05$ \\
\hline Po-216 & $3.48 \mathrm{E}+11$ & $1.43 \mathrm{E}+10$ & $4.09 \mathrm{E}-02$ & $2.858 \mathrm{E}-02$ & $1.17 \mathrm{E}-03$ & $1.262 \mathrm{E}-01$ & $5.17 \mathrm{E}-03$ \\
\hline Rn-219 & $1.30 \mathrm{E}+10$ & $5.40 \mathrm{E}+08$ & $4.15 \mathrm{E}-02$ & $2.537 \mathrm{E}-04$ & $1.05 \mathrm{E}-05$ & $3.823 \mathrm{E}-04$ & $1.59 \mathrm{E}-05$ \\
\hline $\mathrm{RN}-220$ & $9.23 \mathrm{E}+08$ & $3.50 \mathrm{E}+07$ & $3.80 \mathrm{E}-02$ & $2.858 \mathrm{E}-02$ & $1.09 \mathrm{E}-03$ & $1.262 \mathrm{E}-01$ & 4.79E-03 \\
\hline FR-223 & $3.87 \mathrm{E}+07$ & $1.01 \mathrm{E}+05$ & $2.60 \mathrm{E}-03$ & $3.494 \mathrm{E}-06$ & $9.07 \mathrm{E}-09$ & $5.266 \mathrm{E}-06$ & $1.37 \mathrm{E}-08$ \\
\hline RA-223 & $5.12 \mathrm{E}+04$ & $1.82 \mathrm{E}+03$ & $3.56 \mathrm{E}-02$ & $2.537 \mathrm{E}-04$ & $9.03 \mathrm{E}-06$ & $3.823 \mathrm{E}-04$ & $1.36 \mathrm{E}-05$ \\
\hline RA-224 & $1.59 \mathrm{E}+05$ & $5.47 \mathrm{E}+03$ & $3.43 \mathrm{E}-02$ & $2.858 \mathrm{E}-02$ & $9.81 \mathrm{E}-04$ & $1.262 \mathrm{E}-01$ & $4.33 \mathrm{E}-03$ \\
\hline RA-226 & $9.89 \mathrm{E}-01$ & $2.86 \mathrm{E}-02$ & $2.89 \mathrm{E}-02$ & $1.070 \mathrm{E}-07$ & $3.09 \mathrm{E}-09$ & $1.327 \mathrm{E}-07$ & $3.83 \mathrm{E}-09$ \\
\hline RA-228 & $2.34 \mathrm{E}+02$ & $1.80 \mathrm{E}-02$ & $7.71 \mathrm{E}-05$ & $1.655 \mathrm{E}-04$ & $1.28 \mathrm{E}-08$ & $1.402 \mathrm{E}-04$ & $1.08 \mathrm{E}-08$ \\
\hline AC-227 & $7.24 \mathrm{E}+01$ & $3.51 \mathrm{E}-02$ & 4.84E-04 & $2.532 \mathrm{E}-04$ & $1.23 \mathrm{E}-07$ & $3.816 \mathrm{E}-04$ & $1.85 \mathrm{E}-07$ \\
\hline Th-227 & $3.07 \mathrm{E}+04$ & $1.12 \mathrm{E}+03$ & $3.65 \mathrm{E}-02$ & $2.502 \mathrm{E}-04$ & $9.13 \mathrm{E}-06$ & $3.771 \mathrm{E}-04$ & $1.38 \mathrm{E}-05$ \\
\hline Th-228 & $8.20 \mathrm{E}+02$ & $2.68 \mathrm{E}+01$ & $3.27 \mathrm{E}-02$ & $2.853 \mathrm{E}-02$ & $9.33 \mathrm{E}-04$ & $1.260 \mathrm{E}-01$ & 4.12E-03 \\
\hline Th-229 & $2.13 \mathrm{E}-01$ & $6.51 \mathrm{E}-03$ & $3.06 \mathrm{E}-02$ & $6.892 \mathrm{E}-04$ & $2.11 \mathrm{E}-05$ & $9.612 \mathrm{E}-04$ & $2.94 \mathrm{E}-05$ \\
\hline Th-230 & $2.02 \mathrm{E}-02$ & $5.72 \mathrm{E}-04$ & $2.83 \mathrm{E}-02$ & $1.173 \mathrm{E}-05$ & $3.32 \mathrm{E}-07$ & $1.508 \mathrm{E}-05$ & 4.27E-07 \\
\hline Th-231 & $5.32 \mathrm{E}+05$ & $2.98 \mathrm{E}+02$ & $5.61 \mathrm{E}-04$ & $4.333 \mathrm{E}-04$ & $2.43 \mathrm{E}-07$ & $1.630 \mathrm{E}-04$ & $9.14 \mathrm{E}-08$ \\
\hline Th-232 & $1.10 \mathrm{E}-07$ & $2.66 \mathrm{E}-09$ & $2.42 \mathrm{E}-02$ & $1.686 \mathrm{E}-04$ & $4.08 \mathrm{E}-06$ & $1.440 \mathrm{E}-04$ & $3.48 \mathrm{E}-06$ \\
\hline Th-234 & $2.32 \mathrm{E}+04$ & $9.39 \mathrm{E}+00$ & $4.05 \mathrm{E}-04$ & $4.730 \mathrm{E}-06$ & 1.92E-09 & $3.364 \mathrm{E}-06$ & $1.36 \mathrm{E}-09$ \\
\hline PA-231 & $4.73 \mathrm{E}-02$ & $1.42 \mathrm{E}-03$ & $3.01 \mathrm{E}-02$ & $3.666 \mathrm{E}-04$ & $1.10 \mathrm{E}-05$ & $5.930 \mathrm{E}-04$ & $1.79 \mathrm{E}-05$ \\
\hline PA-233 & $2.08 \mathrm{E}+04$ & $4.71 \mathrm{E}+01$ & $2.27 \mathrm{E}-03$ & $6.361 \mathrm{E}-04$ & $1.44 \mathrm{E}-06$ & $2.089 \mathrm{E}-03$ & 4.74E-06 \\
\hline PA-234M & $6.87 \mathrm{E}+08$ & $3.40 \mathrm{E}+06$ & 4.94E-03 & $4.730 \mathrm{E}-06$ & 2.34E-08 & $3.364 \mathrm{E}-06$ & $1.66 \mathrm{E}-08$ \\
\hline PA234 & $2.00 \mathrm{E}+06$ & $2.87 \mathrm{E}+04$ & $1.44 \mathrm{E}-02$ & $6.148 \mathrm{E}-09$ & $8.83 \mathrm{E}-11$ & 4.373E-09 & $6.28 \mathrm{E}-11$ \\
\hline U232 & $2.14 \mathrm{E}+01$ & $6.88 \mathrm{E}-01$ & $3.21 \mathrm{E}-02$ & $2.761 \mathrm{E}-02$ & $8.86 \mathrm{E}-04$ & $1.225 \mathrm{E}-01$ & $3.93 \mathrm{E}-03$ \\
\hline U233 & $9.68 \mathrm{E}-03$ & $2.81 \mathrm{E}-04$ & $2.91 \mathrm{E}-02$ & $1.988 \mathrm{E}-01$ & $5.78 \mathrm{E}-03$ & $3.138 \mathrm{E}-01$ & $9.12 \mathrm{E}-03$ \\
\hline U234 & $6.25 \mathrm{E}-03$ & $8.00 \mathrm{E}-05$ & $2.88 \mathrm{E}-02$ & $3.019 \mathrm{E}-02$ & 8.69E-04 & $3.894 \mathrm{E}-02$ & $1.12 \mathrm{E}-03$ \\
\hline U235 & $2.16 \mathrm{E}-06$ & $5.66 \mathrm{E}-08$ & 2.62E-02 & 4.333E-04 & $1.13 \mathrm{E}-05$ & $1.630 \mathrm{E}-04$ & 4.27E-06 \\
\hline
\end{tabular}


Table 18. (continued).

\begin{tabular}{|c|c|c|c|c|c|c|c|}
\hline Isotope & $\begin{array}{l}\text { Specific } \\
\text { Activity } \\
(\mathrm{Ci} / \mathrm{g})\end{array}$ & $\begin{array}{l}\text { Specific } \\
\text { Heat } \\
(\mathrm{W} / \mathrm{gm})\end{array}$ & $\begin{array}{l}\text { Specific Heat } \\
\text { per Curie } \\
\text { (W/Ci) }\end{array}$ & $\begin{array}{c}\text { Peach Bottom } \\
\text { Core 1 Curies } \\
7 / 1 / 2005\end{array}$ & $\begin{array}{l}\text { Peach Bottom } \\
\text { Core } 1 \text { Watts }\end{array}$ & $\begin{array}{c}\text { Peach Bottom } \\
\text { Core } 2 \text { Curies } \\
7 / 1 / 2005\end{array}$ & $\begin{array}{l}\text { Peach Bottom } \\
\text { Core } 2 \text { Watts }\end{array}$ \\
\hline U236 & $6.47 \mathrm{E}-05$ & $1.75 \mathrm{E}-06$ & $2.71 \mathrm{E}-02$ & $1.288 \mathrm{E}-03$ & $3.49 \mathrm{E}-05$ & $1.892 \mathrm{E}-03$ & $5.12 \mathrm{E}-05$ \\
\hline U237 & $8.17 \mathrm{E}+04$ & $1.55 \mathrm{E}+02$ & $1.89 \mathrm{E}-03$ & $4.214 \mathrm{E}-07$ & $7.98 \mathrm{E}-10$ & $1.090 \mathrm{E}-06$ & $2.06 \mathrm{E}-09$ \\
\hline U238 & $3.36 \mathrm{E}-07$ & 8.53E-09 & $2.54 \mathrm{E}-02$ & $4.730 \mathrm{E}-06$ & $1.20 \mathrm{E}-07$ & $3.364 \mathrm{E}-06$ & $8.53 \mathrm{E}-08$ \\
\hline NP237 & $7.05 \mathrm{E}-04$ & $2.16 \mathrm{E}-05$ & $3.06 \mathrm{E}-02$ & $6.361 \mathrm{E}-04$ & $1.94 \mathrm{E}-05$ & $2.089 \mathrm{E}-03$ & $6.38 \mathrm{E}-05$ \\
\hline PU236 & $5.31 \mathrm{E}+02$ & $1.85 \mathrm{E}+01$ & $3.48 \mathrm{E}-02$ & $3.279 \mathrm{E}-09$ & $1.14 \mathrm{E}-10$ & $9.394 \mathrm{E}-08$ & 3.27E-09 \\
\hline PU237 & $1.21 \mathrm{E}+04$ & $1.16 \mathrm{E}+00$ & $9.61 \mathrm{E}-05$ & $1.229 \mathrm{E}-90$ & $1.18 \mathrm{E}-94$ & $0.000 \mathrm{E}+00$ & $0.00 \mathrm{E}+00$ \\
\hline PU238 & $1.71 \mathrm{E}+01$ & $5.68 \mathrm{E}-01$ & $3.32 \mathrm{E}-02$ & $1.707 \mathrm{E}+00$ & $5.66 \mathrm{E}-02$ & $1.710 \mathrm{E}+01$ & 5.67E-01 \\
\hline PU239 & $6.22 \mathrm{E}-02$ & $1.92 \mathrm{E}-03$ & $3.08 \mathrm{E}-02$ & $2.914 \mathrm{E}-02$ & $8.98 \mathrm{E}-04$ & $2.429 \mathrm{E}-02$ & 7.49E-04 \\
\hline PU240 & $2.28 \mathrm{E}-01$ & $7.10 \mathrm{E}-03$ & $3.11 \mathrm{E}-02$ & $2.456 \mathrm{E}-02$ & $7.65 \mathrm{E}-04$ & $3.065 \mathrm{E}-02$ & $9.54 \mathrm{E}-04$ \\
\hline PU241 & $1.03 \mathrm{E}+02$ & $3.20 \mathrm{E}-03$ & $3.10 \mathrm{E}-05$ & $1.718 \mathrm{E}+00$ & 5.33E-05 & $4.444 \mathrm{E}+00$ & $1.38 \mathrm{E}-04$ \\
\hline PU242 & $3.82 \mathrm{E}-03$ & $1.13 \mathrm{E}-04$ & $2.95 \mathrm{E}-02$ & $4.463 \mathrm{E}-05$ & $1.32 \mathrm{E}-06$ & $3.684 \mathrm{E}-04$ & $1.09 \mathrm{E}-05$ \\
\hline PU244 & $1.77 \mathrm{E}-05$ & $5.15 \mathrm{E}-07$ & $2.90 \mathrm{E}-02$ & $2.359 \mathrm{E}-12$ & $6.84 \mathrm{E}-14$ & $1.169 \mathrm{E}-10$ & $3.39 \mathrm{E}-12$ \\
\hline AM241 & $3.43 \mathrm{E}+00$ & $1.14 \mathrm{E}-01$ & $3.32 \mathrm{E}-02$ & $2.605 \mathrm{E}-01$ & $8.65 \mathrm{E}-03$ & $5.025 \mathrm{E}-01$ & $1.67 \mathrm{E}-02$ \\
\hline $\mathrm{AM} 242 \mathrm{M}$ & $9.72 \mathrm{E}+00$ & $3.84 \mathrm{E}-03$ & $3.95 \mathrm{E}-04$ & $1.225 \mathrm{E}-04$ & 4.84E-08 & $3.650 \mathrm{E}-04$ & $1.44 \mathrm{E}-07$ \\
\hline AM242 & $8.09 \mathrm{E}+05$ & $9.40 \mathrm{E}+02$ & $1.16 \mathrm{E}-03$ & $1.219 \mathrm{E}-04$ & $1.42 \mathrm{E}-07$ & $3.632 \mathrm{E}-04$ & $4.22 \mathrm{E}-07$ \\
\hline AM243 & $1.99 \mathrm{E}-01$ & $6.41 \mathrm{E}-03$ & $3.21 \mathrm{E}-02$ & $1.613 \mathrm{E}-04$ & $5.18 \mathrm{E}-06$ & $3.315 \mathrm{E}-03$ & $1.07 \mathrm{E}-04$ \\
\hline CM242 & $3.31 \mathrm{E}+03$ & $3.84 \mathrm{E}+00$ & $1.16 \mathrm{E}-03$ & $1.010 \mathrm{E}-04$ & $1.17 \mathrm{E}-07$ & $3.010 \mathrm{E}-04$ & $3.50 \mathrm{E}-07$ \\
\hline CM243 & $5.17 \mathrm{E}+01$ & $1.90 \mathrm{E}+00$ & $3.67 \mathrm{E}-02$ & $1.147 \mathrm{E}-04$ & $4.21 \mathrm{E}-06$ & $2.748 \mathrm{E}-03$ & $1.01 \mathrm{E}-04$ \\
\hline CM244 & $8.09 \mathrm{E}+01$ & $2.83 \mathrm{E}+00$ & $3.50 \mathrm{E}-02$ & $3.568 \mathrm{E}-03$ & $1.25 \mathrm{E}-04$ & $2.968 \mathrm{E}-01$ & $1.04 \mathrm{E}-02$ \\
\hline CM245 & $1.72 \mathrm{E}-01$ & $5.70 \mathrm{E}-03$ & $3.32 \mathrm{E}-02$ & $6.763 \mathrm{E}-07$ & 2.24E-08 & $1.160 \mathrm{E}-04$ & $3.85 \mathrm{E}-06$ \\
\hline CM246 & $3.07 \mathrm{E}-01$ & $1.01 \mathrm{E}-02$ & $3.27 \mathrm{E}-02$ & $2.595 \mathrm{E}-08$ & $8.49 \mathrm{E}-10$ & $1.697 \mathrm{E}-05$ & $5.55 \mathrm{E}-07$ \\
\hline \multirow[t]{4}{*}{ CM247 } & $9.28 \mathrm{E}-05$ & $2.97 \mathrm{E}-06$ & $3.20 \mathrm{E}-02$ & $3.671 \mathrm{E}-14$ & $1.17 \mathrm{E}-15$ & $6.571 \mathrm{E}-11$ & $2.10 \mathrm{E}-12$ \\
\hline & & & Total Ci & $4.025 \mathrm{E}+02$ & Total Ci & $9.071 \mathrm{E}+02$ & \\
\hline & & & & & Watts PB C1 & & Watts PB C2 \\
\hline & & & & & $1.23 \mathrm{E}+00$ & & $3.20 \mathrm{E}+00$ \\
\hline
\end{tabular}


The BTU/hr/fuel element is plotted as a function of time in Figure 26.

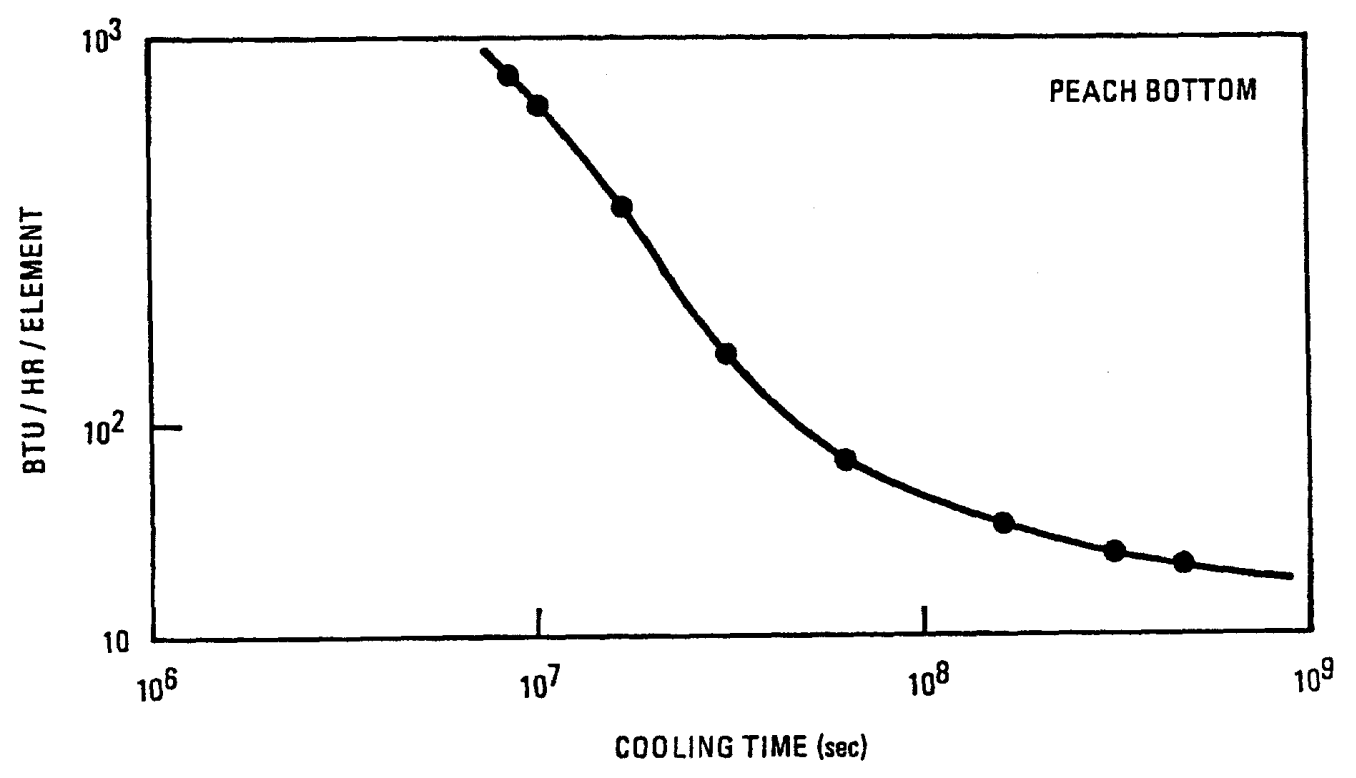

Figure 26. BTU/hr/fuel element versus time. (See Reference 4, Figure 5-1).

The source document did not specify what type of element the curve in Figure 26 represented. It also did not specify which core the element would have come from. 


\section{CORE 1 SPENT FUEL PACKAGING AND STORAGE}

Detailed evaluation of the available information about Core 1 packaging has identified a number of discrepancies. They are discussed throughout this section.

The drawings and package descriptions delivered with the fuel in 1971 would normally be considered the authoritative records. However, the known errors in these documents call into question their overall accuracy.

There are many uncertainties about exactly which revisions of what drawings were actually used for the package components. Table 19 provides a summary of the Core 1 packaging information based on the most probable configurations. Detailed explanations of the rationale for selecting the designs listed in Table 19 are discussed in this section. Because of the uncertainties, appropriate conservatism should be used in evaluating the information presented.

Much of the source document information regarding the Core 1 spent fuel is organized according to the fuel package type, rather than by individual element. Table 19, Types of Core 1 fuel packages, was generally based on a table in Reference 4 . However, there were errors in the Reference 4 table. Package Type 19 was described as representing element number 848, and Package Type 8 was also described as representing element number 848 . Package Type 19 was the type for three elements, not just one. Package Type 19 should have been described as representing elements 830, 831, and 832 as shown in the corrected Table 19 of this report. Additional discrepancies are discussed following Table 19.

Table 19. Types of Core 1 fuel packages_-probable configurations.

\begin{tabular}{|c|c|c|c|c|}
\hline $\begin{array}{c}\text { Fuel } \\
\text { Package } \\
\text { Type }\end{array}$ & $\begin{array}{l}\text { Number } \\
\text { of } \\
\text { Elements }\end{array}$ & Description & Can Drawing & $\begin{array}{l}\text { Estimated } \\
\text { Weight }\end{array}$ \\
\hline 1 & 528 & $\begin{array}{l}\text { Type I or II fuel element, } \\
\text { regular can and liner. }\end{array}$ & $\begin{array}{l}\text { ED-112274-regular can (includes bottom } \\
\text { plug-ED-112276, baffle pipe- } \\
\text { ED-112277, and liner) } \\
\text { ED-112275-regular cap }\end{array}$ & $150 \mathrm{lb}$ or less \\
\hline 2 & 58 & $\begin{array}{l}\text { Type I or II fuel element, } \\
\text { failed sleeve, normal can, } \\
\text { split liner, spacer, Type } 2 \\
\text { removal tool. }\end{array}$ & $\begin{array}{l}\text { ED-112274-regular can (includes bottom } \\
\text { plug-ED-112276, and split liner but } \\
\text { without baffle pipe) } \\
\text { ED-112275-regular cap } \\
\text { 306916-spacer } \\
800-156-15005 \text {-Type } 2 \text { tool }\end{array}$ & $\begin{array}{l}150 \text { lb or } \\
\text { less-Type } 2 \\
\text { tool and } \\
\text { spacer may } \\
\text { weigh slightly } \\
\text { less than } \\
\text { baffle pipe }\end{array}$ \\
\hline 3 & 7 & $\begin{array}{l}\text { Fuel package Type } 2 \text { with } \\
\text { a Type } 1 \text { removal tool. } \\
\text { (Type I or II elements) }\end{array}$ & $\begin{array}{l}\text { ED-112274-regular can (includes bottom } \\
\text { plug ED-112276, and split liner but without } \\
\text { baffle pipe) } \\
\text { ED-112275-regular cap } \\
\text { 306916-spacer } \\
\text { 800-156-15000 Type } 1 \text { tool }\end{array}$ & $150 \mathrm{lb}$ or less \\
\hline
\end{tabular}


Table 19. (continued).

\begin{tabular}{|c|c|c|c|c|}
\hline $\begin{array}{l}\text { Fuel } \\
\text { Package } \\
\text { Type }\end{array}$ & $\begin{array}{l}\text { Number } \\
\text { of } \\
\text { Elements }\end{array}$ & Description & Can Drawing & $\begin{array}{c}\text { Estimated } \\
\text { Weight }\end{array}$ \\
\hline 4 (a) & 0.7 & $\begin{array}{l}\text { Type II fuel element } \\
\text { (No. 263) broken and } \\
\text { stored in two containers. } \\
\text { Upper portion of element } \\
\text { with } 21 \text { compacts is in a } \\
\text { salvage can with } \\
\text { unmarked salvage cap } \\
\text { with partial Type } 2 \\
\text { removal tool, special } \\
\text { spacer, component } \\
\text { canister, } 4.25 \text { in. spacer } \\
\text { and } 50 \text { lb of steel shot. }\end{array}$ & $\begin{array}{l}\text { H-208944_drawing lists carbon steel } \\
\text { "regular type spacer"-4 1/4 in. special } \\
\text { carbon steel spacer (includes some rubber) } \\
\text { component canister (ED-113354) } \\
\text { ED-114488-Salvage can, including plug } \\
\text { ED-114487 and cap - ED-114488 } \\
\text { Partial Type } 2 \text { tool-800-156-15005 } \\
\text { Steel Shot-50 lb }\end{array}$ & $\begin{array}{l}\text { Unknown- } \\
\text { probably } \\
180 \mathrm{lb}\end{array}$ \\
\hline 4 (b) & 0.3 & $\begin{array}{l}\text { Type II fuel element } \\
\text { (No. 263) broken and } \\
\text { stored in two containers. } \\
\text { Lower portion of element } \\
\text { with } 9 \text { compacts is in a } \\
\text { regular canister (cap } \\
\text { No. 120) with a } 3.25 \text { in. } \\
\text { spacer and a special GA } \\
\text { pulling tool. }\end{array}$ & $\begin{array}{l}\text { H-208944_drawing lists regular can } \\
\text { ED-112274-including split liner, and } \\
\text { plug-ED-112276, but no baffle pipe) } \\
3.25 \text { in. spacer-306916 } \\
\text { Cap (\#120) - ED-112275 } \\
\text { special pulling tool-800-156-15018 }\end{array}$ & $\begin{array}{l}\text { Unknown- } \\
\text { probably } \\
180 \mathrm{lb} \text { or less } \\
\text { (but more than } \\
86 \mathrm{lb} \text { ). }\end{array}$ \\
\hline 5 & 1 & $\begin{array}{l}\text { Type II fuel element } \\
\text { (No. 451), failed sleeve, } \\
\text { normal can, split liner, } \\
\text { spacer, Type } 1 \text { removal } \\
\text { tool. Due to leaking } \\
\text { canister, recanned in } \\
\text { salvage canister with } \\
\text { special vented cap, } \\
\text { unmarked. }\end{array}$ & $\begin{array}{l}\text { ED-112274_(includes bottom plug } \\
\text { ED-112276, and split liner but without } \\
\text { baffle pipe) } \\
\text { ED-12275-regular cap (might not have this } \\
\text { inner cap) } \\
\text { Spacer-306916 } \\
\text { Salvage can ED-114488 - includes plug } \\
\text { ED-114487 } \\
\text { Type } 1 \text { tool-800-156-15000 } \\
\text { F-208945-vented cap }\end{array}$ & $180 \mathrm{lb}$ \\
\hline 6 & 1 & $\begin{array}{l}\text { Type II fuel element } \\
\text { (No. 576), failed sleeve, } \\
\text { Type } 2 \text { removal tool, } \\
\text { component canister } \\
\text { without flare (called } \\
\text { broken element removal } \\
\text { tool canister without flare) } \\
\text { and spacer in salvage } \\
\text { canister, cap No. } 8 \text {. }\end{array}$ & $\begin{array}{l}\text { Component Canister-probably ED-113362 } \\
\text { Spacer-306916 } \\
\text { Salvage can ED-114488, includes plug } \\
\text { ED-114487 } \\
\text { Salvage cap ED-114486 } \\
\text { Type } 2 \text { removal tool—800-156-15005 }\end{array}$ & $\begin{array}{l}\text { Probably } \\
180 \mathrm{lb} \text { (wt of } \\
\text { component } \\
\text { canister is } \\
\text { unknown) }\end{array}$ \\
\hline 7 & 1 & $\begin{array}{l}\text { Type } 2 \text { fuel package in a } \\
\text { salvage canister (cap } \\
\text { No. 851, fuel element } \\
\text { No. } 731 \text { ) (Type I or II } \\
\text { element). Should be } \\
\text { Type I element from core } \\
\text { location. }\end{array}$ & $\begin{array}{l}\text { ED-112274-regular can (includes bottom } \\
\text { plug-ED-112276, and split liner but } \\
\text { without baffle pipe) } \\
\text { ED-112275-regular cap (might not have } \\
\text { this inner cap) } \\
306916 \text { - spacer } \\
800-156-15005 \text {-Type } 2 \text { tool } \\
\text { Salvage can ED-114488, includes plug } \\
\text { ED-114487 } \\
\text { Salvage cap ED-114486 }\end{array}$ & $180 \mathrm{lb}$ or less \\
\hline
\end{tabular}


Table 19. (continued).

\begin{tabular}{|c|c|c|c|c|}
\hline $\begin{array}{c}\text { Fuel } \\
\text { Package } \\
\text { Type }\end{array}$ & $\begin{array}{l}\text { Number } \\
\text { of } \\
\text { Elements }\end{array}$ & Description & Can Drawing & $\begin{array}{l}\text { Estimated } \\
\text { Weight }\end{array}$ \\
\hline 8 & 1 & $\begin{array}{l}\text { Type II fuel element } \\
\text { (No. 848) less upper } \\
\text { reflector canned in salvage } \\
\text { canister (component } \\
\text { canister and } 4 \text { in. spacer } \\
\text { inside). Salvage cap is } \\
\text { unmarked. }\end{array}$ & $\begin{array}{l}\text { ED-113362 } \\
\text { Spacer } 4 \text { in.-306916 } \\
\text { Salvage can ED-114488, includes plug } \\
\text { ED-114487 } \\
\text { Salvage cap ED-114486 }\end{array}$ & $\begin{array}{l}\text { Probably } \\
180 \mathrm{lb} \text { (wt of } \\
\text { component } \\
\text { canister is } \\
\text { unknown) }\end{array}$ \\
\hline 9 & 71 & $\begin{array}{l}\text { Type III fuel element, } \\
\text { regular can and liner. }\end{array}$ & $\begin{array}{l}\text { ED-112274-regular can (includes bottom } \\
\text { plug-ED-112276, baffle pipe- } \\
\text { ED-112277, and liner) } \\
\text { ED-112275-regular cap }\end{array}$ & $150 \mathrm{lb}$ or less \\
\hline 10 & 8 & $\begin{array}{l}\text { Fuel package Type } 2 \text { with } \\
\text { a Type III fuel element. }\end{array}$ & $\begin{array}{l}\text { ED-112274-regular can (includes bottom } \\
\text { plug-ED-112276, and split liner but } \\
\text { without baffle pipe) } \\
\text { ED-112275-regular cap } \\
\text { 306916-spacer } \\
\text { 800-156-15005-Type } 2 \text { tool }\end{array}$ & $\begin{array}{l}150 \text { lb or } \\
\text { less-Type } 2 \\
\text { tool and } \\
\text { spacer may } \\
\text { weigh slightly } \\
\text { less than } \\
\text { baffle pipe }\end{array}$ \\
\hline 11 & 1 & $\begin{array}{l}\text { Fuel Package Type } 10 \\
\text { with a hollowed out cap } \\
\text { (No. 90) due to a removal } \\
\text { tool positioned too high } \\
\text { (element No. 126) } \\
\text { (Type III element). }\end{array}$ & $\begin{array}{l}\text { ED-112274-regular can (includes bottom } \\
\text { plug-ED-112276, and split liner but } \\
\text { without baffle pipe) } \\
\text { ED-112275-regular cap (hollowed out) } \\
\text { 306916-spacer (may be cocked per receipt } \\
\text { documents) } \\
\text { 800-156-15005-Type } 2 \text { tool }\end{array}$ & $\begin{array}{l}150 \text { lb or less } \\
\text { Type } 2 \text { tool } \\
\text { and spacer } \\
\text { may weigh } \\
\text { slightly less } \\
\text { than baffle } \\
\text { pipe }\end{array}$ \\
\hline 12 & 1 & $\begin{array}{l}\text { Fuel Package Type } 10 \\
\text { recanned in salvage } \\
\text { canister with cap C5 } \\
\text { (element No. 306) } \\
\text { (Type III element). }\end{array}$ & $\begin{array}{l}\text { ED-112274-regular can (includes bottom } \\
\text { plug-ED-112276, and split liner but } \\
\text { without baffle pipe) } \\
\text { ED-112275-regular cap } \\
\text { 306916-spacer } \\
800-156-15005 \text {-Type } 2 \text { tool } \\
\text { Salvage can ED-114488, includes plug } \\
\text { ED-114487 } \\
\text { Salvage cap ED-114486 }\end{array}$ & $180 \mathrm{lb}$ or less \\
\hline 13 & 1 & $\begin{array}{l}\text { Type } 10 \text { fuel package } \\
\text { (element No. 870) in can } \\
\text { No. } 14 \text { (cap unmarked) } \\
\text { with Type } 1 \text { removal tool } \\
\text { (Type III element). }\end{array}$ & $\begin{array}{l}\text { ED-112274-regular can (includes bottom } \\
\text { plug-ED-112276, and split liner but } \\
\text { without baffle pipe) } \\
\text { ED-112275-regular cap } \\
\text { 306916-spacer } \\
\text { 800-156-15000-Type } 1 \text { tool }\end{array}$ & $150 \mathrm{lb}$ or less \\
\hline 14 & 98 & $\begin{array}{l}\text { Type IV fuel element, } \\
\text { regular can and liner. }\end{array}$ & $\begin{array}{l}\text { ED-112274-regular can (includes bottom } \\
\text { plug-ED-112276, baffle pipe- } \\
\text { ED-112277, and liner) } \\
\text { ED-112275-regular cap }\end{array}$ & $150 \mathrm{lb}$ or less \\
\hline
\end{tabular}


Table 19. (continued).

\begin{tabular}{|c|c|c|c|c|}
\hline $\begin{array}{l}\text { Fuel } \\
\text { Package } \\
\text { Type }\end{array}$ & $\begin{array}{l}\text { Number } \\
\text { of } \\
\text { Elements }\end{array}$ & Description & Can Drawing & $\begin{array}{l}\text { Estimated } \\
\text { Weight }\end{array}$ \\
\hline 15 & 5 & $\begin{array}{l}\text { Type } 2 \text { fuel package with } \\
\text { acoustic thermometer } \\
\text { installed (Type I or II } \\
\text { elements). }\end{array}$ & $\begin{array}{l}\text { ED-112274-regular can (includes bottom } \\
\text { plug-ED-112276, and split liner but } \\
\text { without baffle pipe) } \\
\text { ED-112275-regular cap } \\
\text { 306916-spacer } \\
\text { 800-156-15005-Type } 2 \text { tool }\end{array}$ & $150 \mathrm{lb}$ or less \\
\hline 16 & 1 & $\begin{array}{l}\text { Type } 15 \text { fuel package (fuel } \\
\text { element No. 807) in } \\
\text { can } 01 \text {, cap unmarked, } \\
\text { with a Type } 1 \text { removal } \\
\text { tool. (Type I or II } \\
\text { element). Should be } \\
\text { Type I element per core } \\
\text { location. With acoustic } \\
\text { thermometer. }\end{array}$ & $\begin{array}{l}\text { ED-112274-regular can (includes bottom } \\
\text { plug-ED-112276, and split liner but } \\
\text { without baffle pipe) } \\
\text { ED-112275-regular cap } \\
\text { 306916-spacer } \\
\text { 800-156-15000-Type } 1 \text { tool }\end{array}$ & $150 \mathrm{lb}$ or less \\
\hline 17 & 1 & $\begin{array}{l}\text { Type } 1 \text { fuel package (fuel } \\
\text { element No. } 808 \text { and cap } \\
\text { No. } 252 \mathrm{R} \text { ) with acoustic } \\
\text { thermometer installed } \\
\text { (Type I or II elements). } \\
\text { Should be Type II element } \\
\text { per core location. }\end{array}$ & $\begin{array}{l}\text { ED-112274_regular can (includes bottom } \\
\text { plug-ED-112276, baffle pipe- } \\
\text { ED-112277, and liner) } \\
\text { ED-112275-regular cap }\end{array}$ & $150 \mathrm{lb}$ or less \\
\hline 18 & 18 & $\begin{array}{l}\text { Type } 1 \text { fuel package with } \\
\text { thermocouple installed } \\
\text { (Type I or II elements). }\end{array}$ & $\begin{array}{l}\text { ED-112274_regular can (includes bottom } \\
\text { plug-ED-112276, baffle pipe- } \\
\text { ED-112277, and liner) } \\
\text { ED-112275-regular cap }\end{array}$ & $150 \mathrm{lb}$ or less \\
\hline 19 & 3 & $\begin{array}{l}\text { Type } 2 \text { fuel package } \\
\text { (element Nos. 830, 831, } \\
\text { 832) with thermocouple } \\
\text { installed (Type I or II } \\
\text { elements). }\end{array}$ & $\begin{array}{l}\text { ED-112274-regular can (includes bottom } \\
\text { plug-ED-112276, and split liner but } \\
\text { without baffle pipe) } \\
\text { ED-112275-regular cap } \\
\text { 306916-spacer } \\
\text { 800-156-15005-Type } 2 \text { tool }\end{array}$ & $150 \mathrm{lb}$ or less \\
\hline 20 & 3 & $\begin{array}{l}\text { Type } 9 \text { fuel package with } \\
\text { thermocouple installed } \\
\text { (Type III elements). }\end{array}$ & $\begin{array}{l}\text { ED-112274_regular can (includes bottom } \\
\text { plug-ED-112276, baffle pipe- } \\
\text { ED-112277, and liner) } \\
\text { ED-112275-regular cap }\end{array}$ & $150 \mathrm{lb}$ or less \\
\hline 21 & 4 & $\begin{array}{l}\text { Type } 14 \text { fuel package with } \\
\text { thermocouple installed } \\
\text { (Type IV elements). }\end{array}$ & $\begin{array}{l}\text { ED-112274-regular can (includes bottom } \\
\text { plug-ED-112276, baffle pipe- } \\
\text { ED-112277, and liner) } \\
\text { ED-112275-regular cap }\end{array}$ & $150 \mathrm{lb}$ or less \\
\hline
\end{tabular}


Although Reference 4 and other recent documents refer to a stainless steel canister liner, this appears to be incorrect. Reference 4 has the following information. Most of Core 1 is currently stored in dry wells in CPP-749 at INTEC at the INEEL. Because of the large failure rate for the Core 1 fuel particles, each individual Core 1 fuel element was placed in a double O-ring sealed aluminum (6061) canister with a stainless steel liner at the Peach Bottom Atomic Power Station after removal from the HTGR. The stainless steel liner resists corrosion and is a neutron absorber. The 90 failed fuel elements (with cracked sleeves) were removed from the core with a stainless-steel failed fuel element tool, and both the tool and the element were placed in a canister. Figures 27 and 28 (Reference 4) illustrate the canisters and fuel elements without and with the removal tool, respectively. Figure 29 (Reference 4) shows a salvage canister surrounding a leaking canister. The removal and canning of the Core 1 fuel elements resulted in 21 fuel package types listed in Table 3.4 of Reference 4.

Earlier documents and drawings consistently give 1020 mild steel as the material for the liner. Page II-296 of Reference 9 states, "Each canister contains a carbon steel liner which increases the weight of the canister and adds sufficient neutron absorption to ensure a subcritical array when the spent fuel is stored in the spent-fuel pit.

The additional weight of the liner ensured the canisters would not float when stored underwater. The canister and contents needed to weigh at least $86 \mathrm{lb}$ to overcome the buoyancy of the canister (see Reference 9). In canisters that had fuel removal tools encasing the fuel, the liner was split vertically into two halves ${ }^{23}$ to open it up enough to allow room for the fuel and the tool to fit inside the liner.

While the drawings in Figures 28 and 29 are helpful illustrations of the package configurations, there are some aspects that appear to be in error. Figure 28 shows the liner reaching to the "shoulder" of the removal tool, rather than just to the shoulder of the element. The drawing of the aluminum spacer, Figure 30, shows several variations, up to 3.5 in. high. The baffle pipe drawing, Figure 31, on the other hand shows a height of 24 in. The split liner would be expected to slide around the aluminum spacer to the bottom of the canister, but the regular liner would sit on top of the baffle pipe. So, rather than reaching higher in a canister with the aluminum spacer instead of the baffle pipe, the liner would be expected to be 24 in. lower.

Figure 32 shows the Core 1 canister drawing and gives the length of the 1020 mild steel liner as $9 \mathrm{ft} 8 \mathrm{in}$. Some documents such as Reference 23 give the liner length as $10 \mathrm{ft}$.

Figure 28 gives GA Drawing No. 800-156-15005 (Figure 33) for both the Type 1 and Type 2 removal tools. Documents that were delivered in 1971 as part of the fuel receipt criteria (Peach Bottom-FRC-0012A) ${ }^{24}$ list Drawing 800-156-18000 (Figure 34) for the Type 1 tool. It is likely that the correct drawing for the Type 1 tool is actually 800-156-15000, Figure 35. The available tool drawings are in poor condition. The bases for considering 800-156-15000 as the correct Type 1 tool drawing are:

One, the description in Reference 5, pages 37-38, of the tool surrounding the first failed Core 1 element, C05-05, correlates well with Drawing 800-156-15000, "a cylindrical sleeve made of 35-mil-wall stainless steel having a diameter slightly larger than that of a fuel element...with a normal fuel handling knob at the top and with spring loaded fingers at the bottom... The six springs and fingers are contained in housings outside the tubular sleeve...the fingers engage the tapered portion of the fuel element bottom connector and lift the element....modifications were made.... slotting the lower half of the tool to increase its flexibility and reducing the wall thickness near the bottom..." The document also states that the tool was tested in a mockup in 1966. 


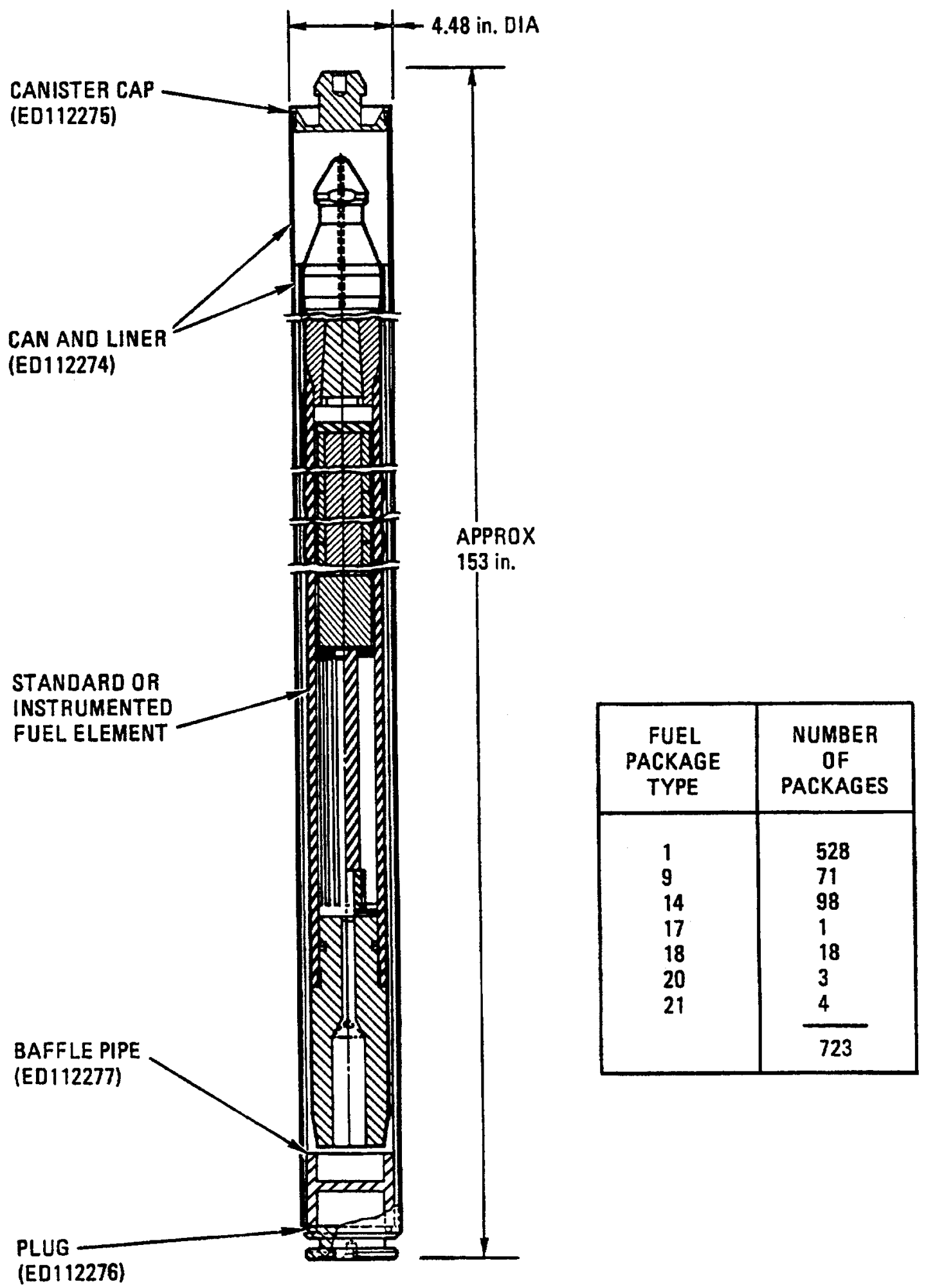

Figure 27. Core 1 fuel element in canister without removal tool (see Reference 4, Figure 3-10). 


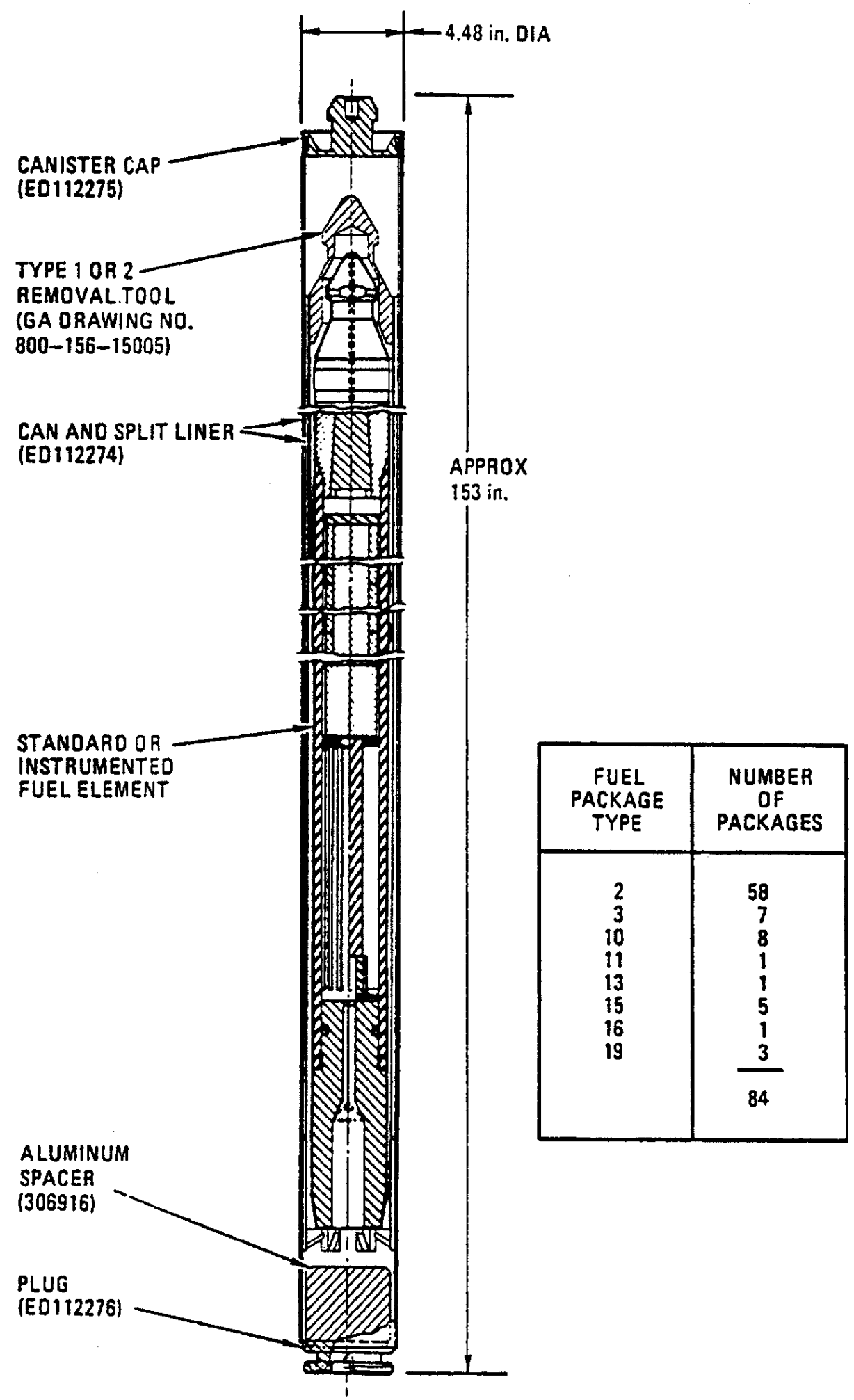

Figure 28. Core 1 fuel element in canister with removal tool (see Reference 4, Figure 3-11). 


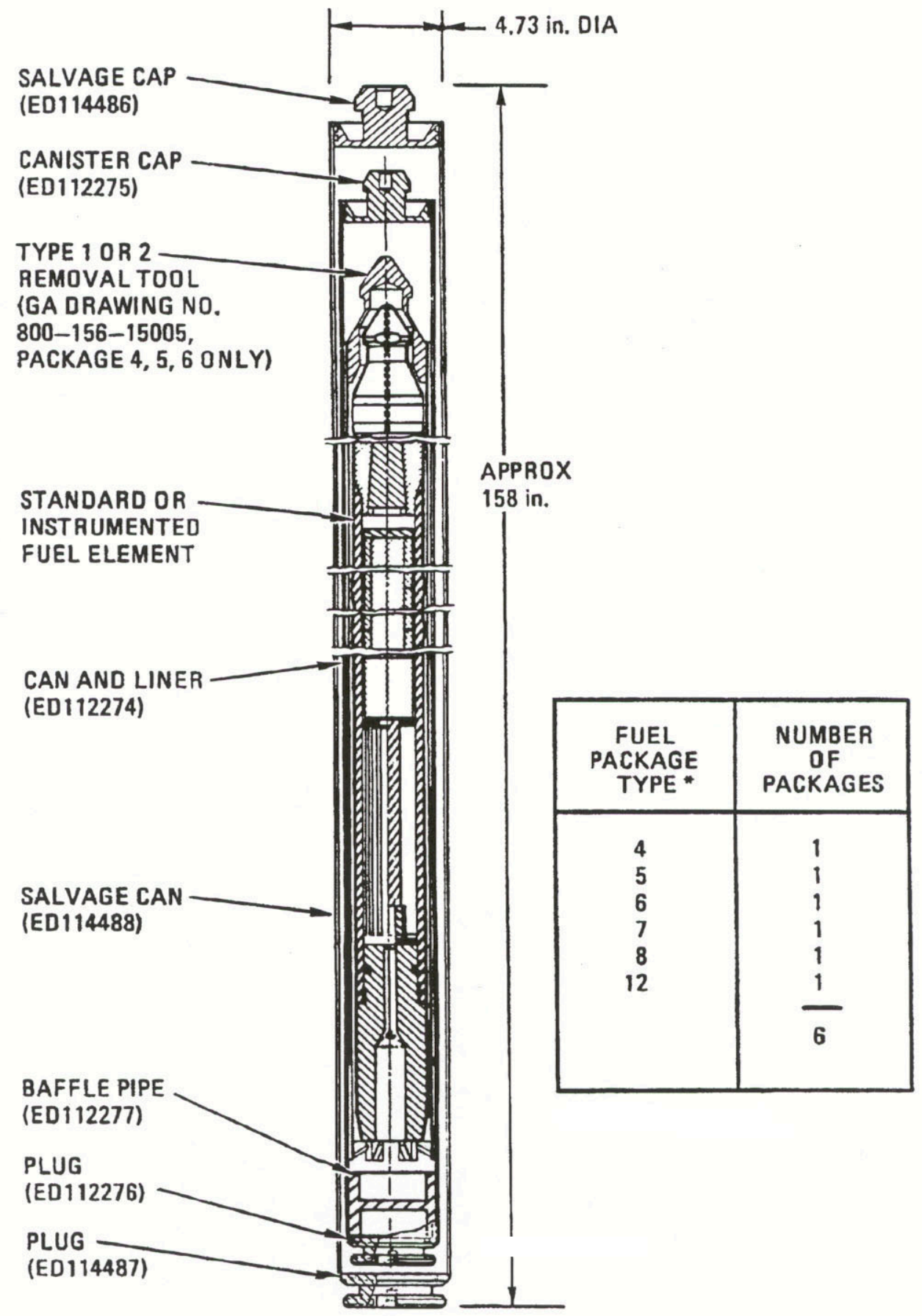

Salvage canister surrounding a leaking canister with a removal tool.

Figure 29. Core 1 fuel element with removal tool in storage canister inside of a salvage canister (see Reference 4, Figure 3-12). 


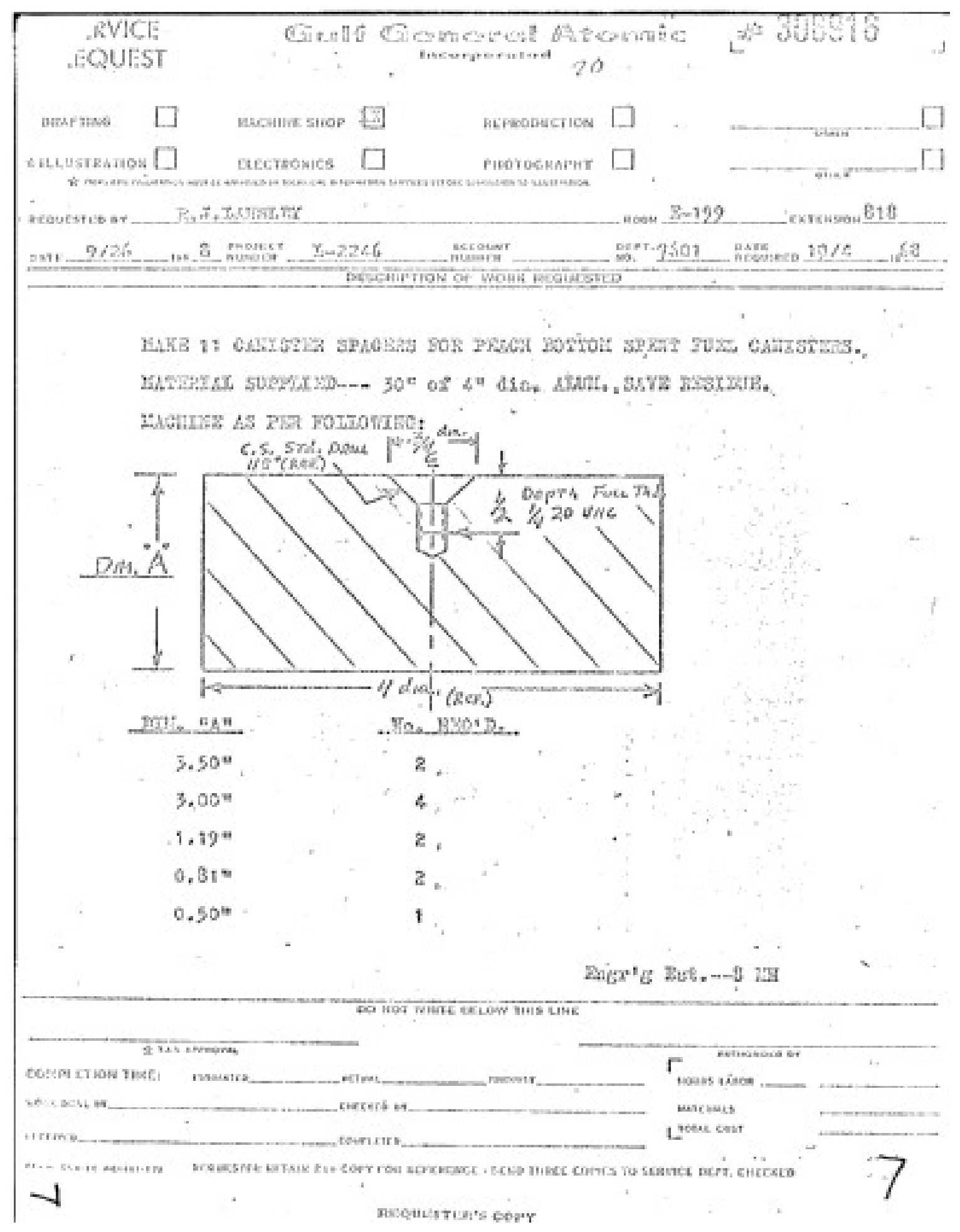

Figure 30. Aluminum spacer Drawing 306916 (Gulf General Atomics Service Request, PEACH BOTTOM-DWG-0039). 


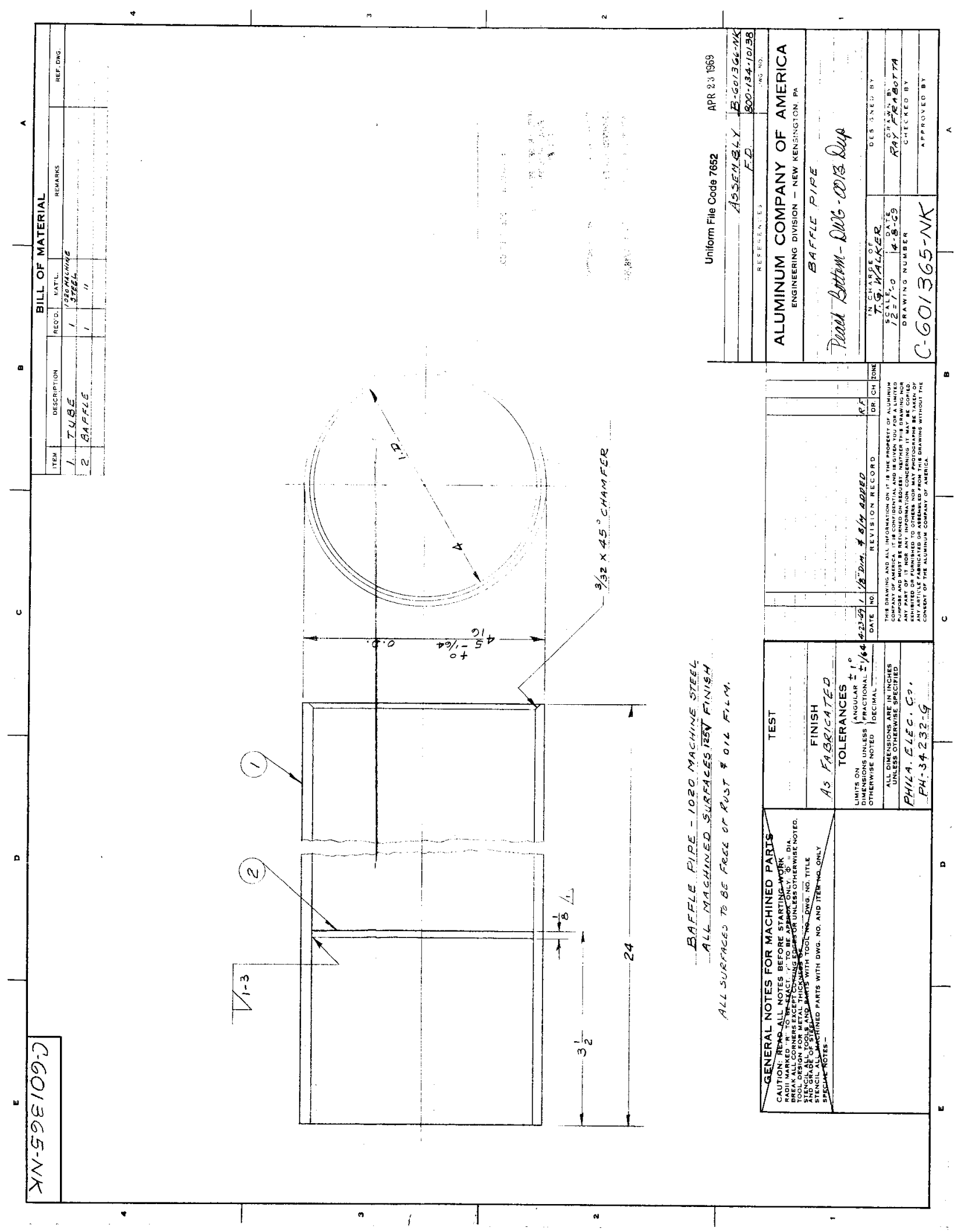

Figure 31. Baffle Pipe (Alcoa, Peach Bottom-DWG-0013 Dup) C-601365-NK. This drawing is also referred to as ED-112277 and 800-134-10138 in various documents. 


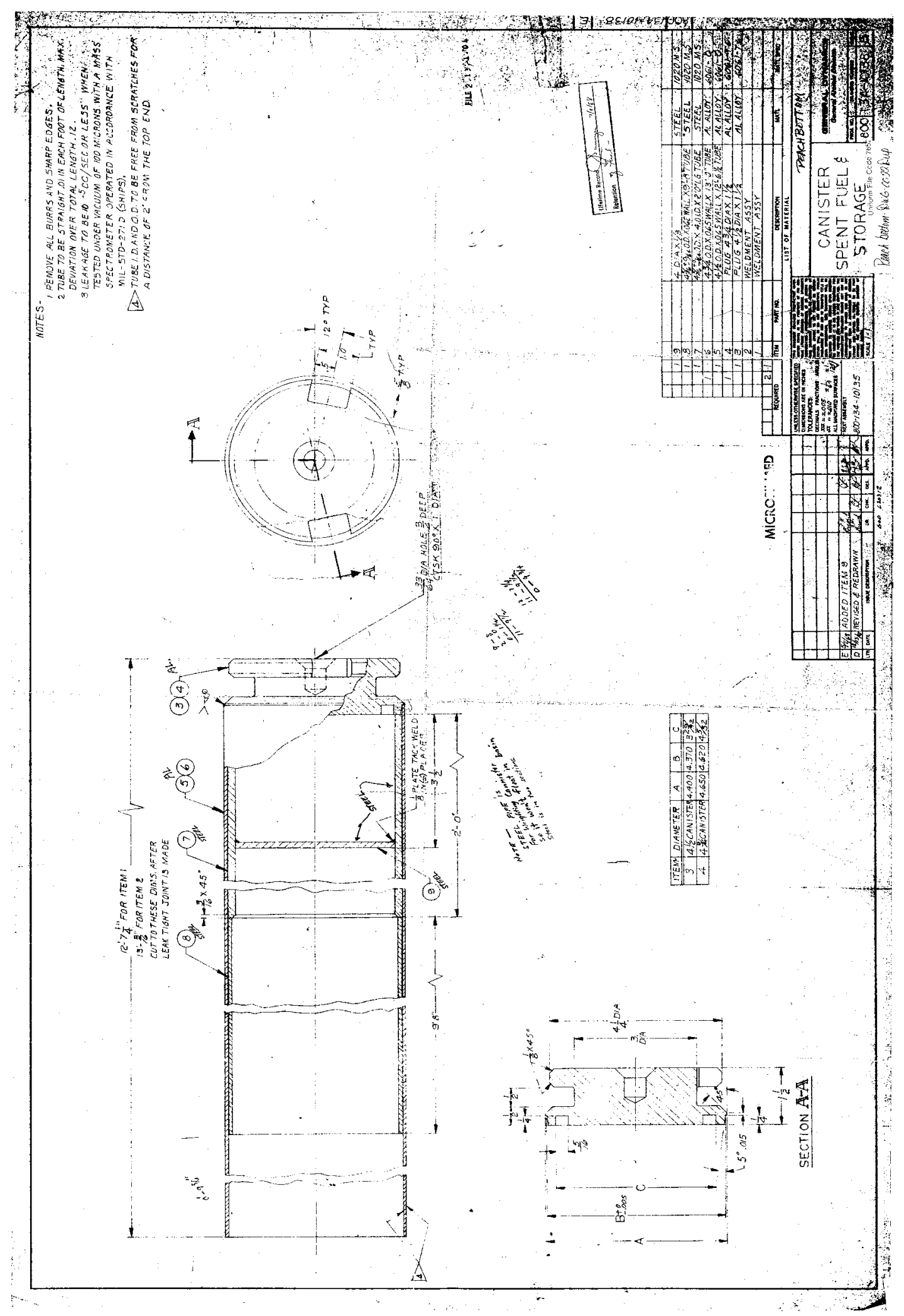

Figure 32. Core 1 canister, (General Dynamics) Peach Bottom-DWG-0022 Dup, also, B-601366-NK, ED-112274, and 800-134-10138. 


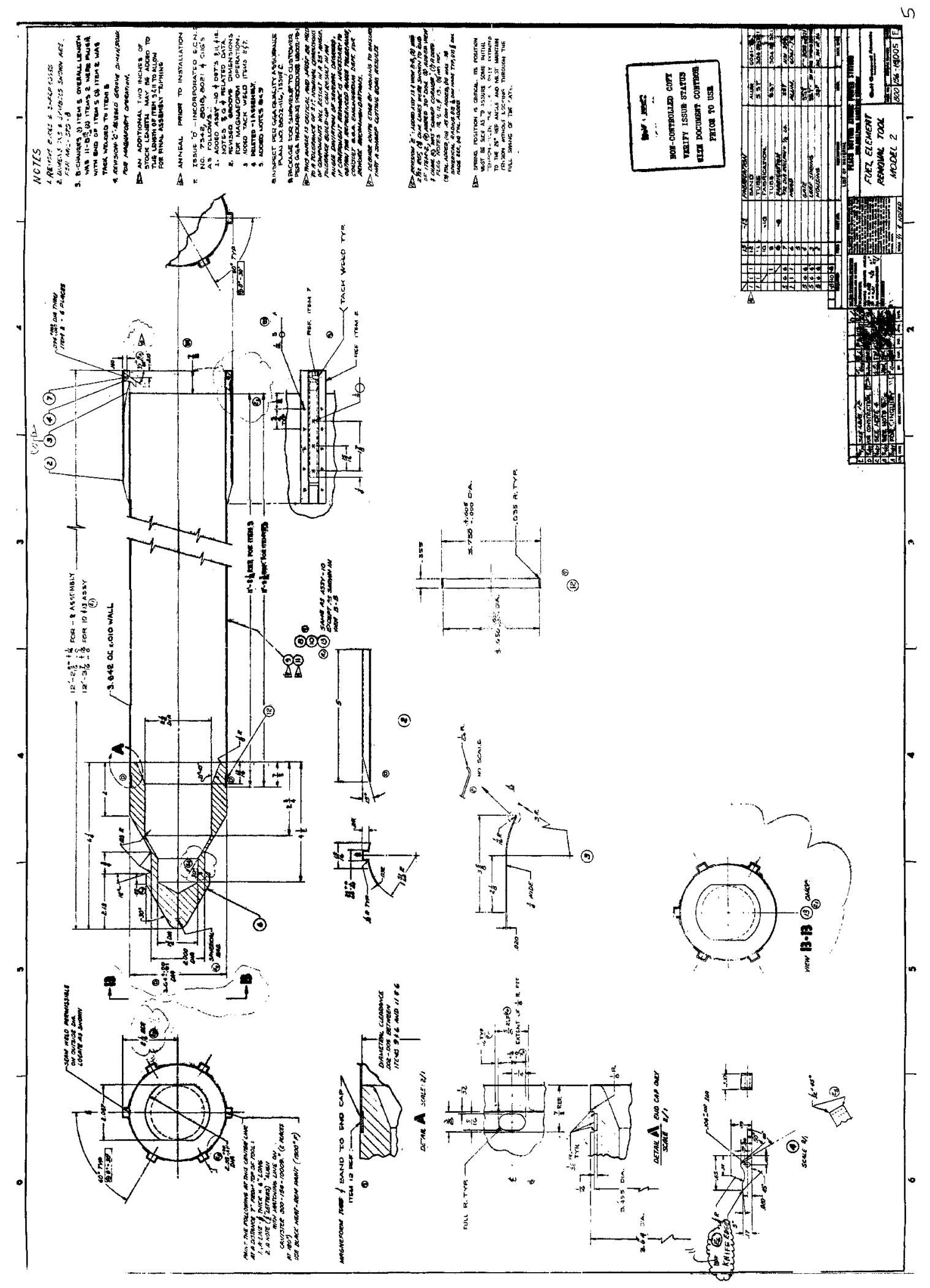

Figure 33. Fuel element removal tool, (Gulf General Atomics) Drawing 800-156-15005, the Type 2 tool. 


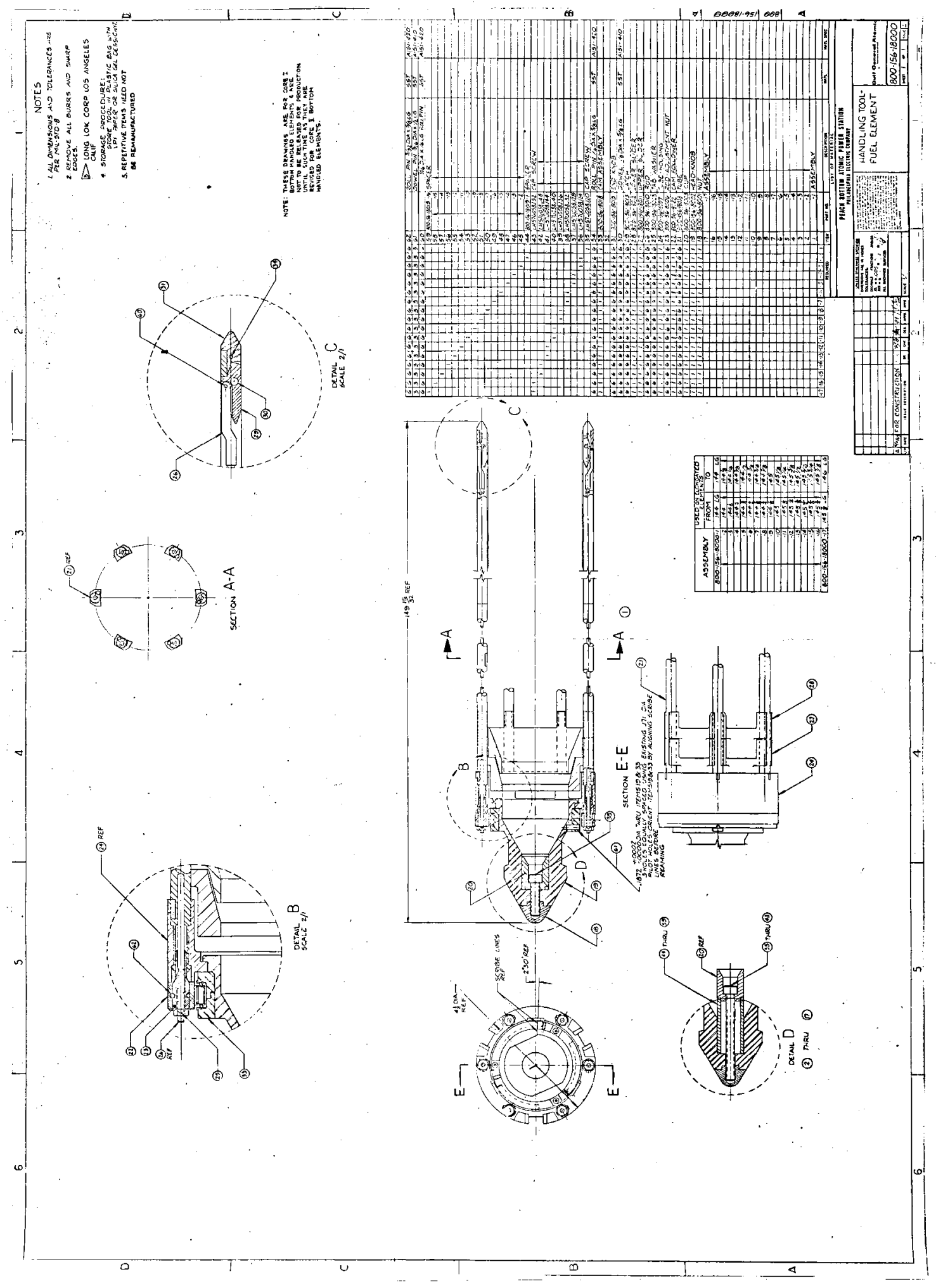

Figure 34. Fuel element removal tool, (Gulf General Atomics) Drawing 800-156-18000, dimensions not compatible with Core 1 canister. 


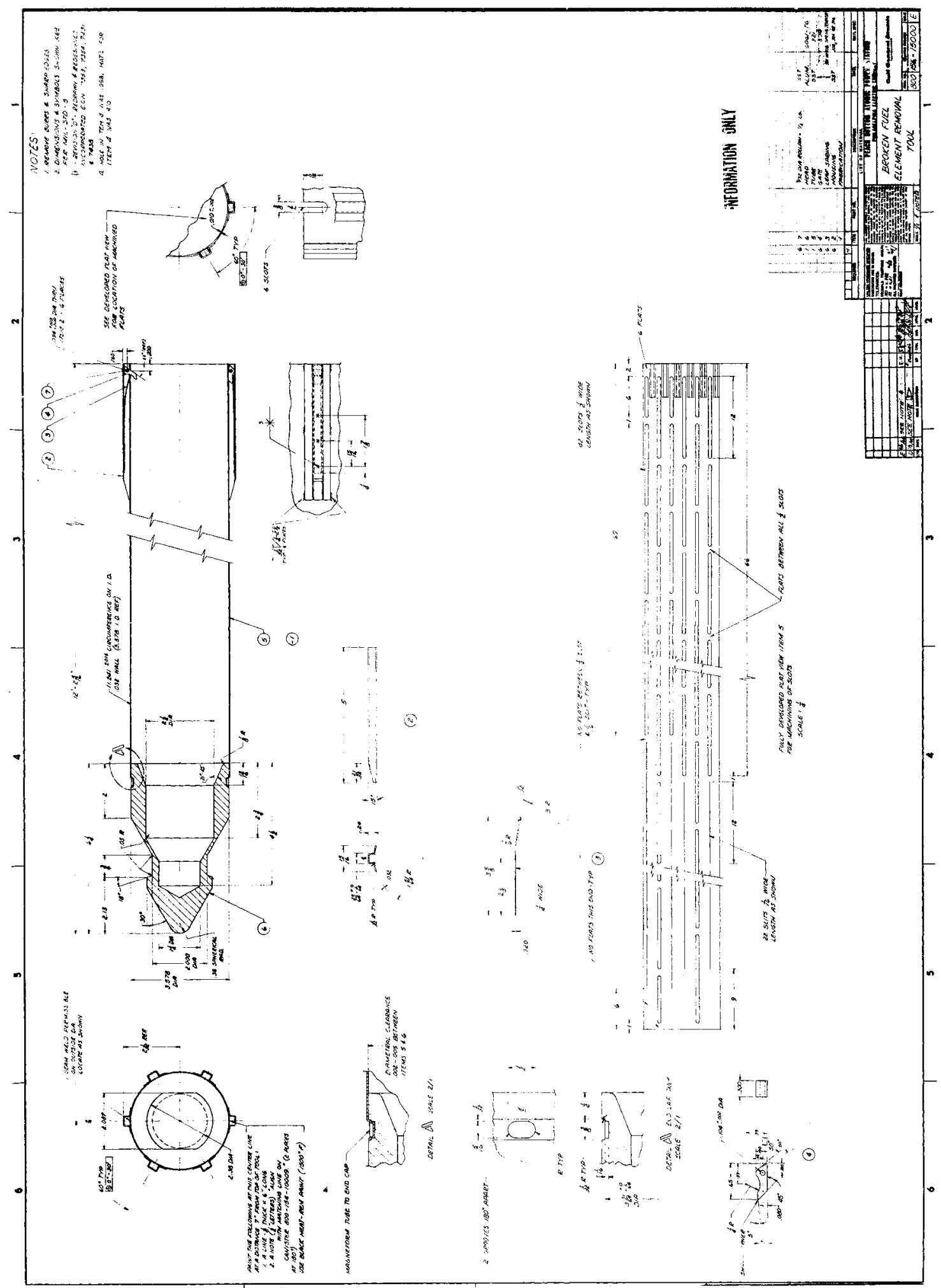

Figure 35. Fuel element removal tool, (Gulf General Atomics) Drawing 800-156-15000-Probably the Type 1 tool. 
Two, descriptions of modifications to the tools and dates in Reference 2, along with the dates on the drawings and the sequential drawing numbers tend to support the conclusion. However, the correlations are not always exact for all pieces of information.

Three, the tool in Drawing 800-156-18000 would not fit inside the canister, much less the liner. The drawing also has this notation, "These drawings are for Core I bottom handled elements and are not to be released for production until such time as they are revised for Core I bottom handled elements." The notation is not clearly legible. It could actually say "... until they are revised for Core II bottom handled elements." The note doesn't make much sense either way, it just calls into question the validity of the drawing.

Four (possibly the strongest reason), in response to a recent request from the INEEL for drawings of the Type 1 and Type 2 tools, GA personnel sent drawings 800-156-15000 and 800-156-15005, respectively.

Five, the instructions to Bidders and Specification for Nuclear Fuel Shipping Cask \& Transportation, Philadelphia Electric Company, Peach Bottom Atomic Power Station Unit No. 1, attached to Reference 23, shows the removal tool Drawing 800-156-15000.

A difference in the designs of 800-156-15000 (about $14 \mathrm{lb}$ ) and 800-156-18000 (20 lb) includes that the former is partly aluminum (the handling knob is aluminum) and the latter is all steel; in addition, the 800-156-18000 tool has a greater diameter.

Figure 29 again lists only one of the tool drawings. It also shows a baffle pipe instead of an aluminum spacer, which is probably incorrect. A handling tool would not fit in the canister if a 24-in. baffle pipe were used under the fuel element. The element would slip into the top 20 in. of the baffle pipe, but the tool outer diameter of $41 / 16$ in. or 4 1/8 in. would not fit into the 4 -in. ID of the baffle pipe. Figure 29 does not indicate that the liner would be split. Documents indicate that the liners were split to allow a tool to fit inside the liner. Drawings indicate that the 800-156-15000 and 800-156-15005 tools should have been able to fit into the 4.188 in.-ID liner without splitting it, but the tolerances might have been too tight for normal operations.

Information from Peach Bottom-FRC-0012A (see Reference 24) was used in EDF-2873. ${ }^{25}$ This EDF has detailed information about the storage locations and packaging; however, the referenced Master List of Fuel from 1971 (see Reference 24) appears to have errors in addition to those described above that were not identified until after the EDF was issued. A list of all the probable errors noted follows:

- Drawing ED-112277 is given as a drawing of a split liner or of a regular liner. It is instead a drawing of a 24-in. high baffle-pipe that is in the bottom of a regular canister.

- $\quad$ There is no separate drawing of just a liner or split liner.

- $\quad$ Drawing ED-112274 is a drawing of a regular canister and liner and baffle pipe and bottom plug but is given as a drawing of just a regular canister.

- Drawing 800-156-18000 is given for the Type 1 tool. It would not fit in the canister. It is almost certain that the correct drawing for the Type 1 tool is actually 800-156-15000, which is not listed. However, there may have been more than one drawing design revision used for the Type 1 tool.

- Drawing ED-113354 is given as a drawing of a component canister. It is also called a broken element removal tool canister without flare. The drawing is mostly illegible. The material is 
stainless steel. This isn't necessarily an error, but the poor drawing makes calculation of the component weight impossible.

- Drawing ED-113362 is also given as a drawing of a component canister. The material for ED-113362 is not specified on the drawing. In the fuel receipt documentation, fuel assembly Type 8 , which includes this canister, implies this might be an aluminum cylinder. But it also refers to a "Dwg. \#1," which is an error, because the "Dwg. \#1" in this case is of a fuel element, not a container.

- $\quad$ The special pulling tool for element No. 263 is listed as $800-156-10018$ with a handwritten change to $800-156-15018$.

- The only spacer drawing, 306916, does not cover the range of spacers described in the package type listings.

- The package type listings never refer to the use of a baffle pipe as shown in the canister drawing.

- $\quad$ Package Type 19 was described as representing element No. 848. However, Package Type 8 was also described as representing element No. 848. Also, Package Type 19 was the type for three elements - not just one. Package Type 19 should have been described as representing element Nos. 830, 831, and 832

Many documents say that after the canisters were loaded with fuel, they were sealed then backfilled with helium and leak tested. The drawings show no means to backfill the canisters. Research of early documents found the explanation in Reference 9 that described how the sealing operation in the canning station was done in a helium atmosphere. The seals were then leak tested with a vacuum device.

A precise description of the sealing process was not located. The bottom plug is consistently described as welded. The top cap was sealed by a process referred to in several documents as "magnaform closure." Reference 9 refers to the process as welding and as providing an hermetic seal. Peach Bottom Cask-SAR-0000, ${ }^{26}$ page 13, states that "An Aluminum cap is hermetically sealed to the can by magnetic swagging."

After canning, the canisters were stored underwater in the Peach Bottom fuel storage pool.

The canisters were shipped to the INEEL in the two Peach Bottom-1 fuel-shipping casks. These casks now have the INEEL identification numbers CA-SF-005 and CA-SF-006. The fuel elements were positioned in the casks in a basket assembly capable of containing 18 fuel elements. Once at the INEEL, the entire basket loaded with canisters was lowered into a drywell at CPP-749 at INTEC at the INEEL.

Table 20 gives approximate weights of various core components from Reference 4.

Reference 4 gives the weight of a loaded basket as 3,620 lb based on 18 loaded fuel cans weighing $150 \mathrm{lb}$ each and an empty basket weight of $920 \mathrm{lb}$. This weight does not take into account differences in weight because of salvage cans, handling tools, special spacers, component canisters, missing baffle pipes, etc.

Reference 9 states that the regular canister weight is $18 \mathrm{lb}$. The mild steel liner was added to bring the total weight to $61 \mathrm{lb}$. This was so the loaded canisters would not float in the Peach Bottom spent fuel pool, even if only a partial fuel element was loaded into the canister. The standard elements weigh $90 \mathrm{lb}$ each. The weight of a standard element in a standard can with liner would then be $151 \mathrm{lb}$. 
Table 20. Approximate weights of various Core 1 and 2 components (see Reference 4, Section 3.4).

\begin{tabular}{|c|c|}
\hline \multicolumn{2}{|l|}{ Weights } \\
\hline \multicolumn{2}{|c|}{ Assembly Weights } \\
\hline \multicolumn{2}{|c|}{ The weights of the different styles of fuel elements are listed below: } \\
\hline & Approximately \\
\hline Standard fuel element & $41 \mathrm{~kg}$ \\
\hline Instrumented fuel element & $41 \mathrm{~kg}$ \\
\hline Fuel test element (PTE designs) & $45 \mathrm{~kg}$ \\
\hline Fuel test element (others) & $41 \mathrm{~kg}$ \\
\hline Core 2 cut-off fuel element & $38 \mathrm{~kg}$ \\
\hline Core 2 cut-off instrumented fuel element & $38 \mathrm{~kg}$ \\
\hline Core 1 fuel element with storage canister & $68 \mathrm{~kg}$ \\
\hline Storage basket with Core 1 fuel & $1,642 \mathrm{~kg}$ \\
\hline \multicolumn{2}{|c|}{ Component Weights } \\
\hline & Approximately \\
\hline Upper reflector & $6 \mathrm{~kg}$ \\
\hline Sleeve & $13 \mathrm{~kg}$ \\
\hline Lower reflector & $0.6 \mathrm{~kg}$ \\
\hline Internal trap & $2 \mathrm{~kg}$ \\
\hline Bottom connector & $3 \mathrm{~kg}$ \\
\hline Fuel compact assembly & $5 \mathrm{~kg}$ \\
\hline Fuel compact & $0.4 \mathrm{~kg}$ \\
\hline \multicolumn{2}{|c|}{ Material Weights } \\
\hline
\end{tabular}

Each standard fuel element contains the following quantities of materials:

\begin{tabular}{lll}
\multicolumn{1}{c}{ Material } & & \multicolumn{1}{c}{ Approximately } \\
\cline { 1 - 1 } Carbon & $33 \mathrm{~kg}$ \\
Stainless steel & & $5 \mathrm{~g}$ \\
Uranium & & $140.7-312.39 \mathrm{~g}$ (initial) \\
Thorium & & $1.37-3.46 \mathrm{~kg}$ (initial) \\
Rhodium & $0-18.54 \mathrm{~g}^{\mathrm{a}}$ \\
Boron & $0-18.3 \mathrm{~g}^{\mathrm{a}}$ \\
Silicon & $15 \mathrm{~g}$
\end{tabular}

a. A similar table in PB-0066 has 0-31 $\mathrm{g}$ and 0-15 $\mathrm{g}$ for thorium and rhodium, respectively—but elsewhere gives the quantities shown here. The numbers here appear to be correct. 
The Battelle Memorial Institute Cask Safety Analysis Report (SAR) (see Reference 26, Table 1) lists $3,420 \mathrm{lb}$ as the weight of the fuel and canisters. The document assumed 19 canisters per basket with an individual maximum of $180 \mathrm{lb} /$ canister. On page 5, the SAR refers to this as the maximum weight. (Early documents assumed the 19 tubes in a basket could each hold a fuel canister; however, the central tube was blocked with a handling fixture when the basket was modified to support unloading the casks into the CPP-749 storage vaults. No more than 18 elements are in any basket.) The SAR for the Peach Bottom cask (see Reference 26, page 4) gives a weight of $920 \mathrm{lb}$ for the empty fuel basket.

Reference 23, which includes Instructions to Bidders and Specification for Nuclear Fuel Shipping Cask \& Transportation, Appendix A, states, "The Maximum Weight of any canned element is 180 pounds."

It is reasonable to assume the referenced documents anticipated that the heaviest canisters would be those that had a regular loaded canister inside of a salvage canister. In calculating the maximum weights, the documents apparently assumed there could be 19 such canisters in a basket.

A maximum of one salvage can was included in a basket. Six of the baskets contained one salvage can each. One of the tubes (the number one position) will take a longer canister than the other tubes and was used for the salvage can if one was included in the basket. If the basket did not have a salvage can, a spacer was put in the bottom of the tube so it would hold a regular can at the same height as the other 17 cans.

In light of the unknowns about the canister weights, the INEEL undertook the task of calculating the weights of the different package components. ${ }^{27}$ Calculations indicate that the nominal weight of a regular canister with plug, liner, baffle pipe, cap and fuel element is slightly less than $150 \mathrm{lb}$. The results also indicate that removal of the baffle pipe compensates for the weight added by a Type 2 tool or the Type 1 tool (if it is the 800-156-15000 design). Calculations also indicate the aluminum basket would weigh only $799 \mathrm{lb}$ rather than $920 \mathrm{lb}$. However, the lack of information about dimensions, materials, drawing revisions, etc., for the more unusual package types makes precise calculations impossible.

Because there is a maximum of one salvage can in a basket and that would be the heaviest can in most cases, it seems probable that the nominal weight of a loaded basket as received from Peach Bottom would be less than $(150 \mathrm{lb} \times 17)+(180 \mathrm{lb} \times 1)+799 \mathrm{lb}=3,529 \mathrm{lb}$. The INEEL calculations indicate a maximum weight of $3,470 \mathrm{lb}$, assuming $180 \mathrm{lb}$ per canister for package types with significant components for which the weights could not be calculated.

The basket in which the fuel was shipped was aluminum, constructed of 18 tubes in two concentric circles around a central $19^{\text {th }}$ tube. The drawings are not in good condition. The drawing numbers are 500213 Rev. 6, 500214 Rev. 6, 500215 Rev. 3, 500216, Rev. 3, 500217 Rev. 2, 500218 Rev. 2, 500245 Rev. 4, and 500269 Rev. 2.

The loaded baskets were lowered into underground vertical storage vaults for interim storage. Routine monitoring and sampling for selected gases were conducted on the vaults. In 1987, because of the presence of krypton and hydrogen in several of the samples, several of the vaults were examined using boroscope cameras.

The removal of one of the loaded baskets from its vault to allow closer examination in the IFSF fuel handling cell was initiated. During the removal, one of the individual storage canisters was inadvertently pushed through the bottom of the storage basket. Recovery from this incident required a new stainless steel storage basket design. All 18 individual storage canisters were placed into this new basket. The basket was then transferred to a new underground storage vault (Vault PWR 1) constructed to 
a second generation design. Transfer of the remaining fuel from the original storage vaults to the newer vaults was started. Five additional baskets have been moved to date. A stainless steel support plate and support rod to prevent the loss of individual storage canisters through the bottom of the baskets during the transfers were installed on the aluminum baskets that were moved (see Reference 25). The support plate drawing number is 097329 Rev 1.

The drawing numbers for the stainless steel basket are 099054 Rev. 1, 099055 Rev. 1, 099056 Rev. 1. The stainless steel basket weight is approximately $600 \mathrm{lb}$. It is planned that test elements from Core 2 that will be received in the future from ORNL will be packaged in a similar stainless steel basket and stored in one of the newer storage wells at CPP-749 at INTEC. Figure 36 shows a drawing of the stainless steel storage basket.

The support plate assembly weighs about $140 \mathrm{lb}$ which when added to the probable maximum weight of a basket as received from Peach Bottom would give a probable total maximum weight of a loaded aluminum basket, including support assembly, of 3,610 lb. The two package Type 4 canisters have the most unknowns about their total weights, and both are stored in the same basket. It seems possible that the Type 4 (a) that contains $50 \mathrm{lb}$ of steel shot could weigh more than $180 \mathrm{lb}$. However, it seems unlikely that the maximum weight of $180 \mathrm{lb}$ as stated in the cask safety documents would be disregarded without any documentation. Even if the weight of the Type 4 (a) canister is higher than $180 \mathrm{lb}$, the stainless basket it is in weighs only $600 \mathrm{lb}$ instead of the $799 \mathrm{lb}$ calculated as the weight of the aluminum basket. So the basket weight would still be less than 3,610 lb.

As stated at the beginning of this section, because of the uncertainties, appropriate conservatism should be used in evaluating the information presented. Because the original design for the support plate assembly assumed a weight lower than the 4,340-lb maximum assumed by the cask SAR (see

Reference 26), an engineering analysis was performed for the plate. ${ }^{28}$ The analysis showed the basic plate design was adequate for the 4,340-lb maximum if prescribed assembly procedures were followed. As discussed above, the weight of 4,340 $\mathrm{lb}$ assumed all canisters weighed the 180-lb maximum, and there were 19 canisters in a basket, instead of 18 . The most conservative weight assumption would be that the weight of $4,340 \mathrm{lb}$ could be reduced by $180 \mathrm{lb}$, which would be $4,160 \mathrm{lb}$.

The 46 shipments of Core 1 fuel elements from Peach Bottom to CPP-749 at the INEEL were initiated in August 1971 and were completed by July 1973. PTE-1, a test element from Core 1 was shipped with Shipment 11 of Core 2 fuel in December 1975. PTE-1 is stored in the IFSF in a canister by itself. After being examined by General Atomics (see Reference 5) Core 1 Element E05-05 and part of Core 1 Element C05-05 were shipped in 1974 and stored in the Fuel Element Cutting Facility (FECF) in CPP-603.

Plans are in place to transfer the fuel in the FECF to the IFSF. The planned process is discussed in detail in Plant Safety Document 4.6E. ${ }^{29}$ The fuel in the FECF will be repackaged into overpack cans, Drawing Number 500600 Rev. 5, and then into an IFSF canister, Drawing Number 453318 Rev. 5, with lid Drawing Number 453321 Rev 4. The intact element, E05-05, would be too long to fit into an IFSF canister and will be cut as part of the repackaging.

Monitoring of the CPP-749 storage wells produced evidence that some moisture has accumulated in some of the wells. Helium and krypton have been detected in the atmosphere of some vaults, indicating that some of the canisters may have been breached. Video inspections have identified what appears to be corrosion on the outsides of some of the canisters. The possibility that moisture has been in contact with the fuel elements through breached canisters raises the possibility of reaction of the spent nuclear fuel materials with oxygen and water. 


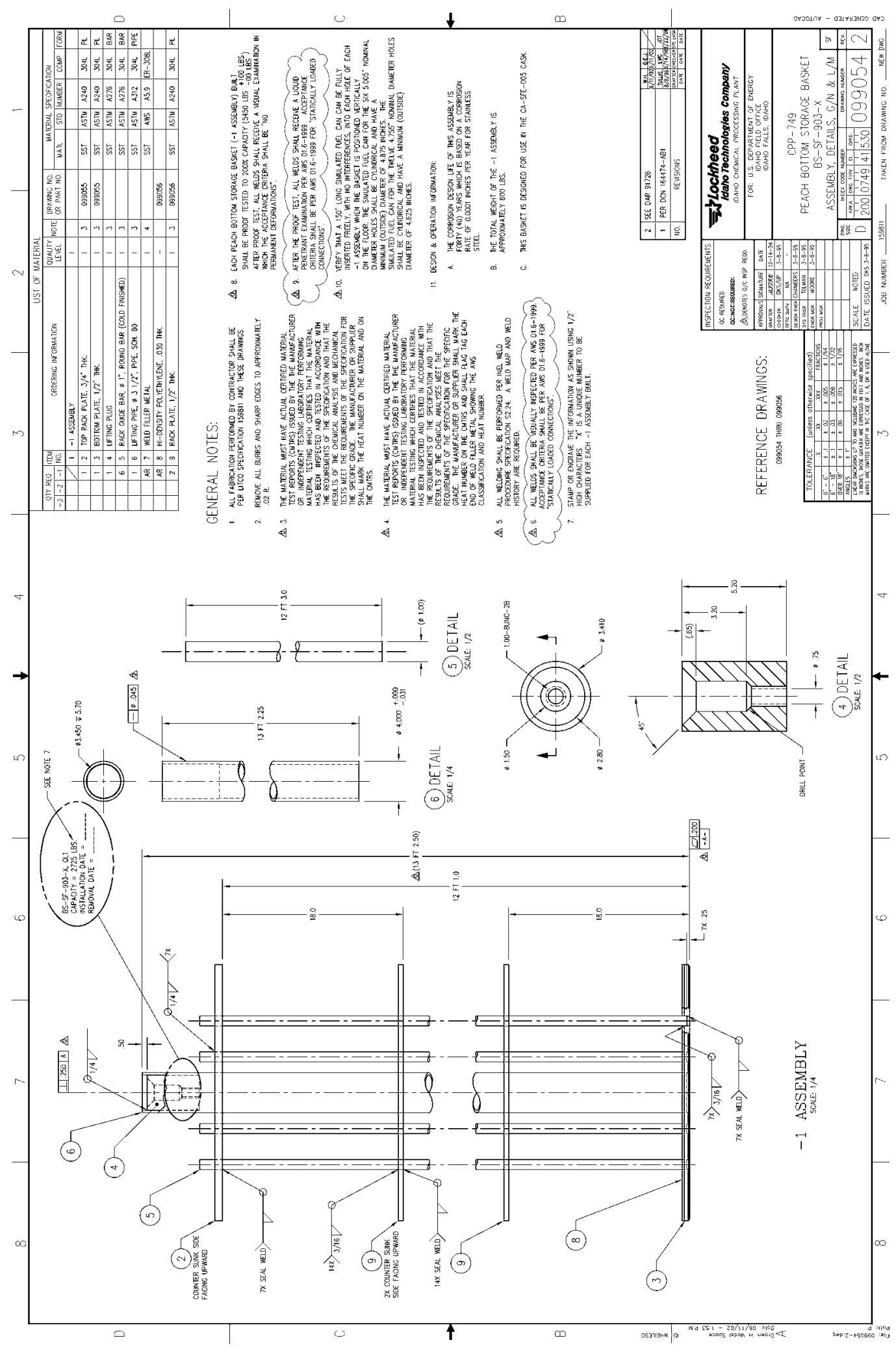

Figure 36. Stainless steel storage basket used for Peach Bottom fuel in CPP-749. 
Oxidation of the graphite components of the Peach Bottom fuel caused by loss of canister integrity is not anticipated to be a major concern, as the process is slow. However, since over 90 of the Peach Bottom Core 1 fuel elements were broken or had failed sleeves, and up to 97\% (see Reference 13) of the particles were failed, loss of fission products from the failed canisters into the storage vaults is a possibility. Also reaction of the $(\mathrm{U}, \mathrm{Th}) \mathrm{C}_{2}$ particle kernels with water and air is a potential concern. When exposed to water the volume of the kernels could increase, further damaging the particle coatings and exposing more carbides to react with water or air. This could further damage the structure of the elements. Also the production of volatile, flammable organics such as acetylene is possible. Table 21 (see Reference 12) shows changes in mass, volume, and density of uncoated $(\mathrm{U}, \mathrm{Th}) \mathrm{C}_{2}$ particles hydrolyzed under various conditions.

Table $22^{30}$ shows a variety of gaseous products that can be formed from $\mathrm{UC}_{2}$ and $\mathrm{ThC}_{2}$ reactions with water.

Corrosion of fuel handling equipment in the vaults from exposure to water is also a concern, both for the potential damage to the equipment and for the potential generation of hydrogen within the vault.

The Peach Bottom storage vaults are monitored for acetylene, hydrogen, helium, krypton, nitrogen, oxygen and xenon. ${ }^{31}$ Sample results are evaluated to determine if corrective actions are needed.

Table 21. Changes in mass, volume, and density of uncoated (Th, $\mathrm{U}) \mathrm{C}_{2}$ particles hydrolyzed under various conditions (see Reference 12, Table 2).

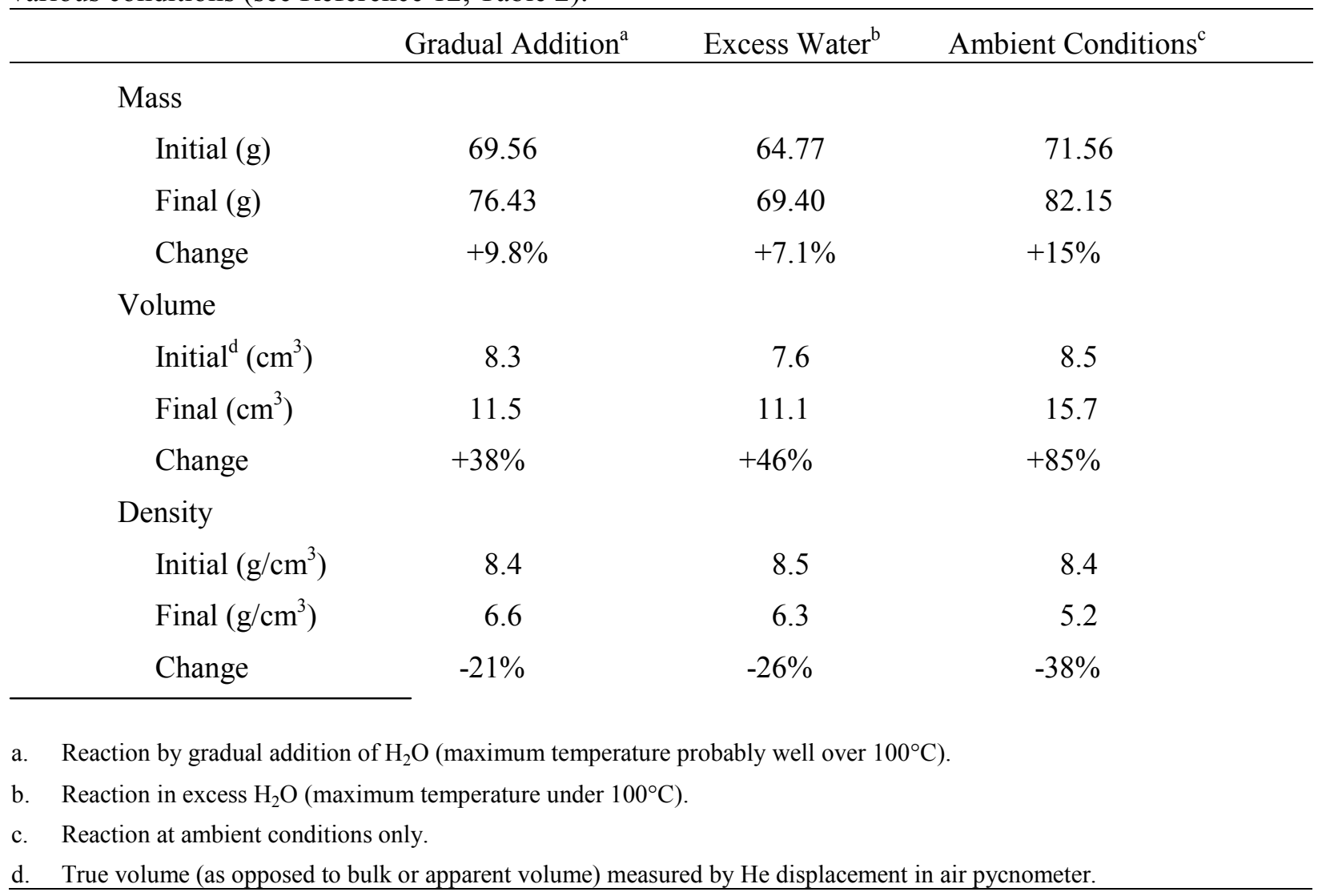


Table 22. Reported offgas compositions from $\mathrm{UC}_{2}$ and $\mathrm{ThC}_{2}$ reactions with water in $\mathrm{mol} \%$ (see Reference 30, Table II).

\begin{tabular}{|l|l|l|l|l|l|l|}
\hline \multicolumn{1}{|c|}{ Compound } & \multicolumn{1}{c|}{$\mathrm{H}_{2}$} & \multicolumn{1}{c|}{$\mathrm{CH}_{4}$} & \multicolumn{1}{c|}{$\mathrm{C}_{2} \mathrm{H}_{2}$} & \multicolumn{2}{c|}{$\mathrm{C}_{2} \mathrm{H}_{4}$} & \multicolumn{2}{c|}{$\mathrm{C}_{2} \mathrm{H}_{6}$} & \multicolumn{2}{c|}{$>\mathrm{C}_{2}$} \\
\hline $\mathrm{UC}_{2}$ & 47 & 10 & Not detected & 7.5 & \multicolumn{2}{|c|}{30} \\
\hline $\mathrm{UC}_{2} @ 30^{\circ} \mathrm{C}$ & Detected & Detected & Not detected & Detected & Detected & Not detected \\
\hline $\mathrm{UC}{ }_{2} @ 50^{\circ} \mathrm{C}$ & Detected & Detected & Not detected & Detected & Detected & Not detected \\
\hline $\mathrm{ThC}_{2}$ & 17.1 & 29.4 & 47.7 & 5.76 & & \\
\hline $\mathrm{ThC}_{2}$ & 59.6 & 10.7 & 15 & 3.1 & 10.7 & 8.8 \\
\hline $\mathrm{ThC}_{2}$ & 27.2 & 2.35 & 9.5 & 2.45 & 29.8 & 27.2 \\
\hline $\mathrm{ThC}_{2} @ 30^{\circ} \mathrm{C}$ & Detected & Detected & Not detected & Not detected & Detected & Detected \\
\hline $\mathrm{ThC}_{2} @ 50^{\circ} \mathrm{C}$ & Detected & Detected & Not detected & Not detected & Not detected & Not detected \\
\hline
\end{tabular}

Because the canisters were stored underwater at the Peach Bottom reactor prior to being sent to the INEEL, there is also a possibility that small amounts of water could have entered the cans if they developed leaks while underwater. Reference 2, the Operating History, page 3-2 states, "It was determined through preliminary tests that the welded method of closure of the spent fuel cans was not acceptable. A modified canning machine utilizing a Magneform method of spent fuel closure was designed by General Atomic. In late September 1966, this machine was shipped to the Peach Bottom site. Checkout of the new system continued through September 1967, when it was shown that all systems operated satisfactorily except for leak-tight sealing of the spent fuel shipping can. The swaging coil and its associated hardware were removed and sent to General Atomic for further testing. Following return of these parts, the entire canning machine operation was successfully demonstrated in January 1968 using the Magneform swaged cap and double O-rings."

O-rings on the cans are "Buna N-4387." This compound is supposed to withstand $1 \times 10^{9}$ roentgens gamma before it becomes brittle. However, high temperatures (over $250^{\circ} \mathrm{F}$ ) could damage it before it received that much radiation. ${ }^{32,33}$

There were several letters and memos discussing the acceptability of the closure. These are listed in the reference section of this report.

The loaded, sealed canisters were stored in the Peach Bottom fuel storage pool prior to shipment.

Reference 2, page 9-1 states, "In late February (1972), a decision was made to extend the outage to accommodate recanning of a leaking spent fuel can stored in the containment vessel. Further delay was encountered when another spent fuel can developed a leak on March 25 and also required recanning.... However, since the first fuel unloading operations in early 1968, only three cans had developed leaks and thus required recanning.

Reference 2, page 10-2 states, "On May 18 (1973), the plant was shut down for a scheduled 3-week outage to allow reswaging of six spent fuel cans in the storage pool..."

From the two quotes, it's not certain which leaking cans were resealed and which were recanned. Because the Core 1 fuel sent to CPP-749 at INTEC was shipped by March 1, 1973, the six cans reswaged after May 18, 1973, would not be part of that fuel. 
In 1972, an element "stored in the containment vessel" would probably have been from Core 2, because Core 2 had been operating since 1970. The leaking can from March 25, 1972, and the unspecified third one that had developed a leak since the first fuel unloading operations, could have been from Core 1 or one of the elements unloaded early from Core 2. There were two elements specified in the Core 1 shipping documents, A07-01 and B14-04, as having been recapped. They were shipped to the INEEL on July 27,1972 . It is possible that these were the ones that developed leaks. It is also possible that the phrase "in the containment vessel" meant in the spent fuel pit, in which case the three elements could all have been from Core 1 .

Four of the six salvage cans sent with Core 1 fuel were shipped to the INEEL in 1971. One was shipped March 2, 1972, and one on November 8, 1972. So it is possible that the three cans that developed leaks could have been recanned into salvage cans. It is also possible that the salvage cans were added to canisters that did not seal well, as a result of vacuum testing before the fuel was stored underwater. Element D08-04 is in a salvage can with a special vented cap and was the one shipped on March 2, 1972. It is possible the vent was used because the inner can had developed a leak while underwater. The vented cap drawing is dated March 12, 1971, so this could have been the first of the three cans that developed leaks.

The documents do not indicate how the leaks discussed in the quotations above were determined. If it was by bubbles noted while stored underwater, it is possible that water entered the cans before they were resealed. Because all the salvage cans and many of the regular cans contained either broken or failed fuel, this raises the possibility of reaction of fuel carbides with water that is undetected because of the sealed canisters. The element that had been in the containment vessel might not have been stored underwater.

The Core 1 standard fuel element initial heavy metal masses are given in Table 8; the Core 2 standard fuel element initial heavy metal masses are given in Table 11. A summary of the postirradiation uranium loadings in Core 1 fuel elements is given by fuel "Package Type" in Table 23 (Reference 4). A summary of the total postirradiation heavy metal loadings for 813 fuel elements in Core 1 is given in Table 24 (Reference 4).

An illustration of the top plan view of CPP-749 and the location of Peach Bottom HTGR Core 1 fuel elements are in Figure 37. 
Table 23. Summary of Core 1 postirradiation uranium loadings per element by fuel package type (see Reference 4, Table 5-7).

\begin{tabular}{|c|c|c|c|c|c|c|c|c|}
\hline $\begin{array}{c}\text { Package } \\
\text { Type }\end{array}$ & $\begin{array}{c}\text { No. of } \\
\text { Elements }\end{array}$ & $\begin{array}{c}\text { Total U } \\
\text { Average }(\mathrm{g}) \\
\text { Maximum }(\mathrm{g})\end{array}$ & $\begin{array}{c}\mathrm{U}-232 \\
\text { Average }(\mu \mathrm{g}) \\
\text { Maximum } \\
(\mu \mathrm{g})\end{array}$ & $\begin{array}{c}\text { U-233 } \\
\text { Average (g) } \\
\text { Maximum } \\
(\mathrm{g})\end{array}$ & $\begin{array}{c}\text { U-234 } \\
\text { Average (g) } \\
\text { Maximum } \\
(\mathrm{g})\end{array}$ & $\begin{array}{c}\text { U-235 } \\
\text { Average (g) } \\
\text { Maximum } \\
(\mathrm{g})\end{array}$ & $\begin{array}{c}\text { U-236 } \\
\text { Average }(\mathrm{g}) \\
\text { Maximum } \\
(\mathrm{g}) \\
\end{array}$ & $\begin{array}{c}\text { U-238 } \\
\text { Average }(\mathrm{g}) \\
\text { Maximum } \\
(\mathrm{g})\end{array}$ \\
\hline 1 & 528 & $\begin{array}{l}268.68 \\
303.81\end{array}$ & $\begin{array}{l}1,645 \\
2,081\end{array}$ & $\begin{array}{l}23.99 \\
27.10\end{array}$ & $\begin{array}{l}3.71 \\
3.89\end{array}$ & $\begin{array}{l}206.46 \\
268.84\end{array}$ & $\begin{array}{l}18.46 \\
20.76\end{array}$ & $\begin{array}{l}16.06 \\
17.10\end{array}$ \\
\hline 2 & 58 & $\begin{array}{l}267.46 \\
283.83\end{array}$ & $\begin{array}{l}1,697 \\
2,081\end{array}$ & $\begin{array}{l}24.39 \\
27.10\end{array}$ & $\begin{array}{l}3.73 \\
3.89\end{array}$ & $\begin{array}{l}204.46 \\
226.93\end{array}$ & $\begin{array}{l}18.84 \\
20.76\end{array}$ & $\begin{array}{l}16.04 \\
16.27\end{array}$ \\
\hline 3 & 7 & $\begin{array}{l}279.24 \\
282.79\end{array}$ & $\begin{array}{l}883 \\
960\end{array}$ & $\begin{array}{l}17.94 \\
19.04\end{array}$ & $\begin{array}{l}3.47 \\
3.49\end{array}$ & $\begin{array}{l}227.35 \\
230.81\end{array}$ & $\begin{array}{l}14.08 \\
14.52\end{array}$ & $\begin{array}{l}16.39 \\
16.50\end{array}$ \\
\hline 4 & 1 & $\begin{array}{l}256.77 \\
256.77\end{array}$ & $\begin{array}{l}1,584 \\
1,584\end{array}$ & $\begin{array}{l}20.42 \\
20.42\end{array}$ & $\begin{array}{l}3.71 \\
3.71\end{array}$ & $\begin{array}{l}197.31 \\
197.31\end{array}$ & $\begin{array}{l}19.06 \\
19.06\end{array}$ & $\begin{array}{l}16.27 \\
16.27\end{array}$ \\
\hline 5 & 1 & $\begin{array}{l}280.85 \\
280.85\end{array}$ & $\begin{array}{l}820 \\
820\end{array}$ & $\begin{array}{l}18.24 \\
18.24\end{array}$ & $\begin{array}{l}3.44 \\
3.44\end{array}$ & $\begin{array}{l}229.11 \\
229.11\end{array}$ & $\begin{array}{l}13.75 \\
13.75\end{array}$ & $\begin{array}{l}16.31 \\
16.31\end{array}$ \\
\hline 6 & 1 & $\begin{array}{l}255.80 \\
255.80\end{array}$ & $\begin{array}{l}1,699 \\
1,699\end{array}$ & $\begin{array}{l}21.36 \\
21.36\end{array}$ & $\begin{array}{l}3.75 \\
3.75\end{array}$ & $\begin{array}{l}194.85 \\
194.85\end{array}$ & $\begin{array}{l}19.62 \\
19.62\end{array}$ & $\begin{array}{l}16.21 \\
16.21\end{array}$ \\
\hline 7 & 1 & $\begin{array}{l}278.49 \\
278.49\end{array}$ & $\begin{array}{l}1,191 \\
1,191\end{array}$ & $\begin{array}{l}22.71 \\
22.71\end{array}$ & $\begin{array}{l}3.53 \\
3.53\end{array}$ & $\begin{array}{l}219.86 \\
219.86\end{array}$ & $\begin{array}{l}16.25 \\
16.25\end{array}$ & $\begin{array}{l}16.14 \\
16.14\end{array}$ \\
\hline 8 & 1 & $\begin{array}{l}297.20 \\
297.20\end{array}$ & $\begin{array}{l}285 \\
285\end{array}$ & $\begin{array}{l}11.00 \\
11.00\end{array}$ & $\begin{array}{l}3.36 \\
3.36\end{array}$ & $\begin{array}{l}257.31 \\
257.31\end{array}$ & $\begin{array}{l}8.60 \\
8.60\end{array}$ & $\begin{array}{l}16.93 \\
16.93\end{array}$ \\
\hline 9 & 71 & $\begin{array}{l}269.79 \\
295.62\end{array}$ & $\begin{array}{l}1,594 \\
2,050\end{array}$ & $\begin{array}{l}23.67 \\
27.04\end{array}$ & $\begin{array}{l}3.68 \\
3.86\end{array}$ & $\begin{array}{l}208.20 \\
258.37\end{array}$ & $\begin{array}{l}18.15 \\
20.33\end{array}$ & $\begin{array}{l}16.08 \\
16.71\end{array}$ \\
\hline 10 & 8 & $\begin{array}{l}268.25 \\
274.76\end{array}$ & $\begin{array}{l}1,836 \\
2,050\end{array}$ & $\begin{array}{l}25.70 \\
27.04\end{array}$ & $\begin{array}{l}3.77 \\
3.86\end{array}$ & $\begin{array}{l}203.54 \\
213.19\end{array}$ & $\begin{array}{l}19.27 \\
20.33\end{array}$ & $\begin{array}{l}15.96 \\
16.05\end{array}$ \\
\hline 11 & 1 & $\begin{array}{l}272.57 \\
272.57\end{array}$ & $\begin{array}{l}1,646 \\
1,646\end{array}$ & $\begin{array}{l}25.21 \\
25.21\end{array}$ & $\begin{array}{l}3.69 \\
3.69\end{array}$ & $\begin{array}{l}209.35 \\
209.35\end{array}$ & $\begin{array}{l}18.31 \\
18.31\end{array}$ & $\begin{array}{l}16.00 \\
16.00\end{array}$ \\
\hline 12 & 1 & $\begin{array}{l}274.64 \\
274.64\end{array}$ & $\begin{array}{l}1,498 \\
1,498\end{array}$ & $\begin{array}{l}24.36 \\
24.36\end{array}$ & $\begin{array}{l}3.63 \\
3.63\end{array}$ & $\begin{array}{l}212.99 \\
212.99\end{array}$ & $\begin{array}{l}17.61 \\
17.61\end{array}$ & $\begin{array}{l}16.05 \\
16.05\end{array}$ \\
\hline 13 & 1 & $\begin{array}{l}285.85 \\
285.85\end{array}$ & $\begin{array}{l}749 \\
749\end{array}$ & $\begin{array}{l}17.82 \\
17.82\end{array}$ & $\begin{array}{l}3.42 \\
3.42\end{array}$ & $\begin{array}{l}235.34 \\
235.34\end{array}$ & $\begin{array}{l}12.87 \\
12.87\end{array}$ & $\begin{array}{l}16.40 \\
16.40\end{array}$ \\
\hline 14 & 98 & $\begin{array}{l}150.41 \\
155.48\end{array}$ & $\begin{array}{l}3,009 \\
3,262\end{array}$ & $\begin{array}{l}34.81 \\
36.28\end{array}$ & $\begin{array}{l}3.19 \\
3.34\end{array}$ & $\begin{array}{l}91.69 \\
96.02\end{array}$ & $\begin{array}{l}11.90 \\
12.33\end{array}$ & $\begin{array}{l}8.81 \\
8.86\end{array}$ \\
\hline 15 & 5 & $\begin{array}{l}268.15 \\
277.75\end{array}$ & $\begin{array}{l}1,715 \\
2,013\end{array}$ & $\begin{array}{l}24.53 \\
25.57\end{array}$ & $\begin{array}{l}3.73 \\
3.84\end{array}$ & $\begin{array}{l}205.07 \\
218.51\end{array}$ & $\begin{array}{l}18.79 \\
20.25\end{array}$ & $\begin{array}{l}16.03 \\
16.13\end{array}$ \\
\hline 16 & 1 & $\begin{array}{l}288.17 \\
288.17\end{array}$ & $\begin{array}{l}651 \\
651\end{array}$ & $\begin{array}{l}16.82 \\
16.82\end{array}$ & $\begin{array}{l}3.40 \\
3.40\end{array}$ & $\begin{array}{l}239.07 \\
239.07\end{array}$ & $\begin{array}{l}12.35 \\
12.35\end{array}$ & $\begin{array}{l}16.53 \\
16.53\end{array}$ \\
\hline 17 & 1 & $\begin{array}{l}277.75 \\
277.75\end{array}$ & $\begin{array}{l}1,279 \\
1,279\end{array}$ & $\begin{array}{l}23.04 \\
23.04\end{array}$ & $\begin{array}{l}3.55 \\
3.55\end{array}$ & $\begin{array}{l}218.51 \\
218.51\end{array}$ & $\begin{array}{l}16.51 \\
16.51\end{array}$ & $\begin{array}{l}16.13 \\
16.13\end{array}$ \\
\hline 18 & 18 & $\begin{array}{l}270.69 \\
283.63\end{array}$ & $\begin{array}{l}1,550 \\
2,013\end{array}$ & $\begin{array}{l}23.62 \\
25.61\end{array}$ & $\begin{array}{l}3.66 \\
3.84\end{array}$ & $\begin{array}{l}209.37 \\
226.63\end{array}$ & $\begin{array}{l}17.95 \\
20.25\end{array}$ & $\begin{array}{l}16.09 \\
16.24\end{array}$ \\
\hline 19 & 3 & $\begin{array}{l}277.57 \\
278.54\end{array}$ & $\begin{array}{l}1,228 \\
1,297\end{array}$ & $\begin{array}{l}22.79 \\
23.00\end{array}$ & $\begin{array}{l}3.54 \\
3.57\end{array}$ & $\begin{array}{l}218.63 \\
219.94\end{array}$ & $\begin{array}{l}16.46 \\
16.90\end{array}$ & $\begin{array}{l}16.14 \\
16.14\end{array}$ \\
\hline 20 & 3 & $\begin{array}{l}268.61 \\
284.63\end{array}$ & $\begin{array}{l}1,378 \\
1,559\end{array}$ & $\begin{array}{l}21.33 \\
22.54\end{array}$ & $\begin{array}{l}3.61 \\
3.68\end{array}$ & $\begin{array}{l}210.09 \\
227.42\end{array}$ & $\begin{array}{l}17.35 \\
18.53\end{array}$ & $\begin{array}{l}16.23 \\
16.26\end{array}$ \\
\hline 21 & 4 & $\begin{array}{l}150.60 \\
155.48 \\
\end{array}$ & $\begin{array}{l}2,933 \\
3,240 \\
\end{array}$ & $\begin{array}{l}34.56 \\
36.17 \\
\end{array}$ & $\begin{array}{l}3.16 \\
3.18 \\
\end{array}$ & $\begin{array}{l}92.24 \\
96.02 \\
\end{array}$ & $\begin{array}{l}11.81 \\
11.96 \\
\end{array}$ & $\begin{array}{l}8.82 \\
8.83 \\
\end{array}$ \\
\hline
\end{tabular}


Table 24. Summary of total postirradiation fuel loadings for 813 Core 1 fuel elements (see Reference 4 , Table 5-8). ${ }^{\mathrm{a}}$

\begin{tabular}{|c|c|}
\hline Isotope & $\begin{array}{c}\text { Calculated } \\
\text { Weights/Concentrations }\end{array}$ \\
\hline $\mathrm{U}-232$ & $1.46 \mathrm{~g}$ \\
\hline $\mathrm{U}-233$ & $20,523.82 \mathrm{~g}$ \\
\hline $\mathrm{U}-234$ & $2,956.24 \mathrm{~g}$ \\
\hline $\mathrm{U}-235$ & $156,518.24 \mathrm{~g}$ \\
\hline $\mathrm{U}-236$ & $14,266.21 \mathrm{~g}$ \\
\hline $\mathrm{U}-238$ & $12,324.92 \mathrm{~g}$ \\
\hline U-total & $206,593.89 \mathrm{~g}$ \\
\hline $\mathrm{Pu}-239$ & $411.17 \mathrm{~g}$ \\
\hline $\mathrm{Pu}-240$ & $82.85 \mathrm{~g}$ \\
\hline $\mathrm{Pu}-241$ & $63.34 \mathrm{~g}$ \\
\hline $\mathrm{Pu}-242$ & $8.31 \mathrm{~g}$ \\
\hline $\mathrm{Pu}$ total & $565.67 \mathrm{~g}$ \\
\hline Pu-fissile & $474.51 \mathrm{~g}$ \\
\hline $\mathrm{Pu}$-fissile/Pu-total & $83.88 \%$ \\
\hline Thorium & $1,439.31 \mathrm{~kg}$ \\
\hline $\mathrm{U}-232$ & $7.08 \mathrm{ppm}$ \\
\hline U-235/U-total & $75.76 \%$ \\
\hline (U-233 and U-235)/U-total & $85.70 \%$ \\
\hline
\end{tabular}

a. This is intended to be for the elements in dry well storage at the INEEL. 


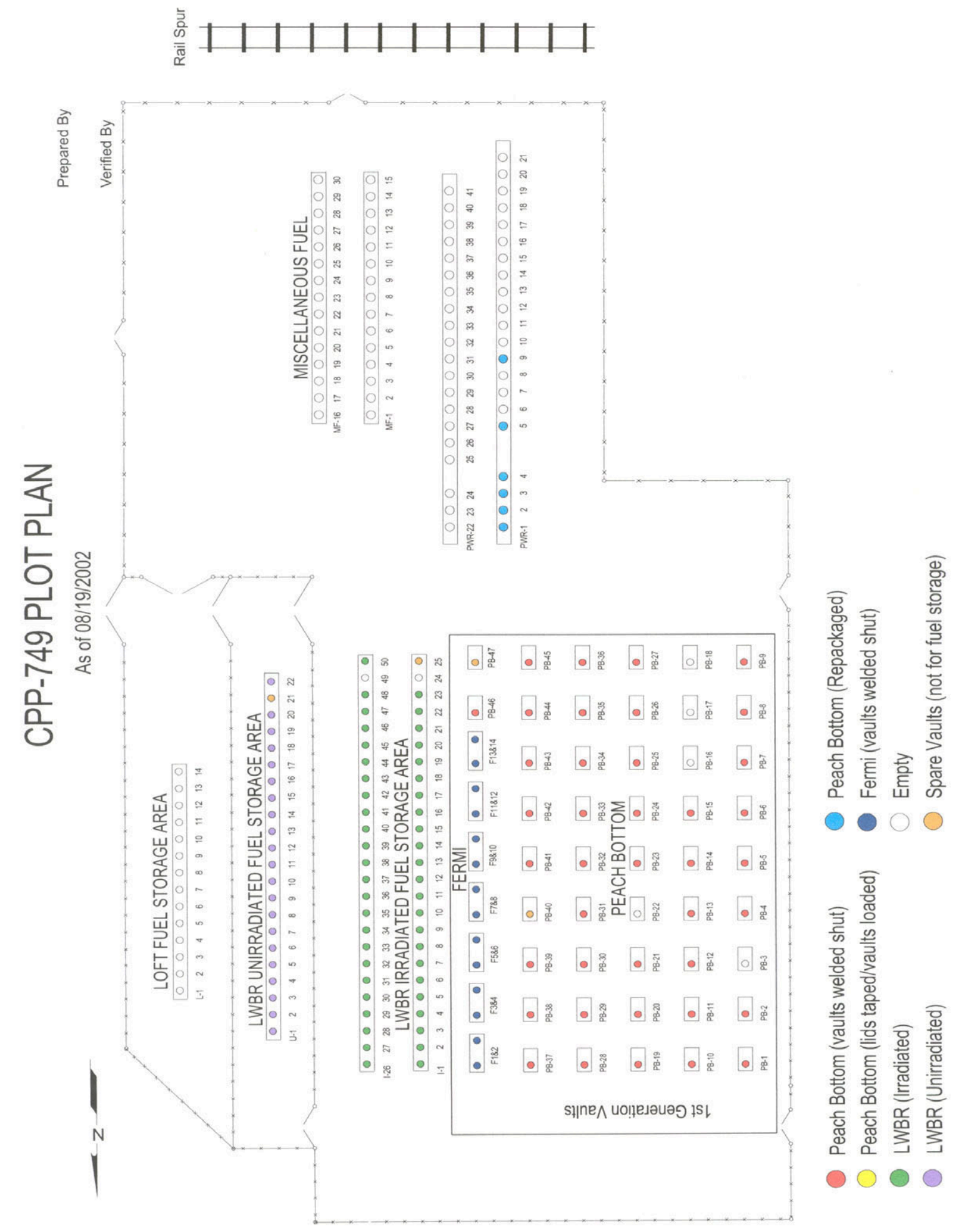

Figure 37. CPP-749 storage facility (plan view) showing locations of Peach Bottom Core 1 fuel baskets as of August 19, 2002. This plot plan is an information only copy. The official copy is updated and maintained by Spent Nuclear Fuel Facilities Support at INTEC. 


\section{DISCUSSION OF CORE 1 TABLE OF SPENT FUEL ELEMENTS}

Appendix A is a copy of an Excel spreadsheet for all Core 1 fuel sorted by storage location as of September 2002 and then by basket position. Many of the oldest source documents refer to core location to identify specific fuel elements. Later documents reference serial number or can number or fuel type or package type only. The table in Appendix A will provide a means to translate between the different identification systems. Extensive research was done using the core layout information given earlier in this document along with the operating history, shipping records, and other sources to correlate the different identification systems. As much information unique to each element as possible is included in the "notes" column of the table. Where there were replacement elements in a single core location, more than one row is included for that location. Some fuel elements were destructively analyzed and no longer exist; as much of this type of information as could be located is included. The table includes elements that are not currently at the INEEL but might be received here in the future. Extensive heavy metal isotopic information for EOL from the original shipping documents has been included in these tables. Hard copy documents PB- $0070^{34}$ for Core 1 and Peach Bottom-FRC- $0019^{35}$ for Core 2 give detailed heavy metal isotope data for each element. These documents have some illegible areas. Several smaller tables with fuel information by fuel type or package type are included in this report for information purposes.

J. R. Brown and K. R. Van Howe ${ }^{36}$ correlate the serial numbers with the initial core locations of the first 682 Core 1 elements loaded. This provided valuable information for completing the Core 1 table.

A letter from F. H. Tingey, Aerojet Nuclear Company to Dr. C. Wayne Bills, AEC $^{37}$ states that GA burn-up calculations for Core 1 fuel were "performed by a fairly sophisticated computer code (GAUGE) which is a two-dimensional four-group diffusion and depletion code well suited to the HTGR core configuration. It calculates the heavy element inventory of each fuel element at the end of each burnup and each shut-down period. When necessary, appropriate corrections are made to compensate for (1) changing power levels during burnup periods and (2) changes in the number and location of inserted control rods. They have checked the code against other burnup codes and, to a limited extent, against results obtained from physical measurements.

Review of the data in Appendix A and Appendix B for U-235 burnup indicates that some elements in Core 1 had a slightly higher burnup than the calculated average of 91 grams used in Table 16 in Section 4. The highest burnup from Appendix A is shown as approximately 96 grams of U-235. While those elements in Core 1 with the highest burnup could have a source term 5\% higher than calculated in the tables from section 4, most Core 1 elements had a lower burnup than 91 grams. The Core 2 data from Appendix B indicates that no Core 2 elements had a higher burnup than was calculated for Table 17 in Section 4.

Master List of Fuel from Peach Bottom I, Appendix A (see Reference 24), has extensive information. However, some errors found in this reference that are identified in this fuel summary were pertinent.

Reference 19 contains detailed information about the Peach Bottom Core 1 fuel and about the Core 2 test elements.

The fuel handling and transfer paperwork sent with the fuel from Peach Bottom is not available except in hard copy for Core 1 . The Core 2 information has record number PB-0164. This paperwork is maintained at INTEC by the SNF Facilities Support organization. In general, a Form ACC-261, Allied Chemical Corporation, and a memo from R. J. Conti, Philadelphia Electric Company to Allied Chemical Corporation regarding Shipping Load Chart, exist for each shipment of Peach Bottom fuel for both Core 1 and Core 2. 
The paperwork for Core 1 provides the shipment number and date, the basket number, the position in the basket, the last core position, the storage position in the spent fuel pit at PB, the vault (silo) number at CPP-749, the serial number, and the can number. The paperwork for Core 2 provides the shipment number and date, the last core position, the spent fuel pit position, the IFSF canister number, the serial number and the can number. Both sets of paperwork sometimes provide other miscellaneous information, have handwritten corrections, possible errors and areas that are illegible. Any subsequent transfers at INTEC are covered by additional transfer paperwork.

The abbreviations CR and ER are used to designate control rods and emergency shutdown rods, respectively. 


\section{CORE 2 SPENT FUEL PACKAGING AND STORAGE}

Following the plant shutdown in October 1974, all 804 fuel elements in the core were removed from the reactor, canned, and placed in the spent fuel pool at Peach Bottom. On June 24, 1975 shipping of the fuel to the INEEL commenced. A total of 44 fuel shipments were made by truck using the two PB-1 fuel shipping casks. In addition to the normal fuel shipments, 27 fuel shipments were made in the single-element Hallam fuel shipping cask to GA and ORNL in support of the Peach Bottom postirradiation examination program conducted by GA. Fuel shipping was completed in February 1977. The spent fuel pool was then drained. ${ }^{38}$

Only the sealed, steel-lined aluminum canister that fit over the Core 1 fuel elements (shown in Figure 27) was used for the Core 2 fuel elements. No failed fuel removal tools or additional salvage canisters were required for Core 2 fuel elements. However, the Core 2 fuel was placed in the IFSF at the INEEL. This required removal of the fuel from the canister and cutting off the top $18 \mathrm{in}$. of reflector to store the elements in the 11-ft-long storage canister. The resulting fuel element length is approximately $10 \mathrm{ft} 6 \mathrm{in}$. long. The aluminum can is not included in the current storage configuration, and there is no grapple knob on the top of the fuel elements for handling purposes. The Core 2 carbon-steel storage canister, which was stored in the IFSF, is illustrated in Figure 38. The canister drawing numbers are 094910, 094911, and 094912. This storage canister contains up to 12 Peach Bottom HTGR Core 2 fuel elements. A fuel element-centering device was used to facilitate loading the Core 2 fuel elements into the canister. Once a canister was loaded, the centering device was removed and used to load the next Core 2 canister. As a result, up to 12 fuel elements in each Core 2 canister are loosely contained and considered to be in uncontrolled configuration for criticality safety analysis.

Operator logs indicate that in addition to four elements that were noted as broken on the fuel receipt documents, one or more elements might have been broken during handling in the IFSF. An informal note "To: IFSF File From: W. F. Hendrickson" dated July 24, 1975 said that "The broken elements are put into a regular cannister (sic), to a limit of eight elements per cannister (sic) rather than the regular twelve per cannister (sic) for unbroken elements."

Most of the Peach Bottom HTGR Core 2 is stored in the INTEC IFSF at the INEEL. Figure 39 illustrates the IFSF layout, which shows the location and serial numbers of the canisters containing the Peach Bottom HTGR Core 2. A shipment of Core 2 test elements and standard elements from ORNL to the INEEL CPP-749 facility at INTEC is planned for the near future.

The IFSF storage canister is vented, so buildup of gaseous products of reaction of the fuel element materials with air is not a concern. The IFSF is a dry facility; however, atmospheric moisture would be in contact with the fuel surfaces. A few of the fuel elements were broken during fuel handling, so release of fission products and gaseous products from U-Th carbide reactions with water are possible. However, because very few of the fuel particle coatings examined were ruptured, the amount of U-Th carbides exposed to air and moisture should be very small.

The postirradiation heavy metal loadings for Core 2 standard fuel elements are given in Table 25 (Reference 4). The Core 2 postirradiation total core heavy metal loadings are given in Table 26 (Reference 4). The Core 2 Test Fuel Element initial heavy metal loadings are given in Table 12. The Core 2 Test Fuel Element postirradiation heavy metal masses are given in Table 13 (Reference 4) and in Table 12.

The Core 2 fuel compact initial heavy metal loadings per fuel compact type are given in Table 10 . The Core 2 initial heavy metal loadings per standard fuel element type are given in Table 11 . 
Table 25. Postirradiation heavy metal loadings for Core 2 (standard) fuel elements (see Reference 4, Table 5-9).

\begin{tabular}{lcc}
\hline Heavy Metal & Types 1, 2, and 3 & Type 4 \\
\hline U-233 & 33.0 & 37.8 \\
Average & 35.2 & 39.1 \\
Maximum & & \\
U-235 & 90.0 & 36.0 \\
Average & 189.0 & 108.4 \\
Maximum & & \\
U-total & 167.0 & 105.0 \\
Average & 228.7 & 108.4 \\
Maximum & 1310 & 2524 \\
Thorium & 0.27 & 0.08 \\
Pu-239 & 0.09 & 0.03 \\
Pu-240 & 0.15 & 0.05 \\
Pu-241 & 0.07 & 0.03 \\
Pu-242 & 0.59 & 0.18 \\
Pu-total & & \\
\hline
\end{tabular}

Table 26. Core 2 postirradiation total core heavy metal masses (December 31, 1974) (see Reference 4, Table 5-10).

\begin{tabular}{llr}
\hline Nuclide & \multicolumn{1}{c}{ Data } & \multicolumn{1}{c}{ Totals } \\
\hline Th-232 & Kilograms & $1,172.54$ \\
Pa-231 & Milligrams & $5,858.77$ \\
Pa-233 & Grams & 305.47 \\
U-232 & Milligrams & $7,484.56$ \\
U-233 & Grams & $25,945.99$ \\
U-234 & Grams & $4,546.84$ \\
U-235 & Grams & $66,962.86$ \\
U-236 & Grams & $21,116.46$ \\
U-238 & Grams & $9,252.53$ \\
Np-239 & Milligrams & 0 \\
Pu-239 & Milligrams & $199,505.53$ \\
Pu-240 & Milligrams & $69,211.53$ \\
Pu-241 & Milligrams & $112,470.13$ \\
Pu-242 & Milligrams & $53,696.54$ \\
Np-237 & Grams & $1,624.52$ \\
Rh-103 & Grams & $2,763.79$ \\
B-10 & Grams & 1.93 \\
$\mathrm{U}$ & Grams & $127,832.20$ \\
$\mathrm{U}-235$ & Weight fraction & 0.5238 \\
$\mathrm{U}-233$ & Weight fraction & 0.2030 \\
$\mathrm{U}-232$ & Parts per million & 58.55 \\
\hline
\end{tabular}


The weight of the Core 2 IFSF storage canister (see Figure 38$)$ is approximately $318 \mathrm{~kg}(700 \mathrm{lb})$. The cut-off Core 2 fuel element weighs $38 \mathrm{~kg}$ (Table 18). There are up to 12 cut-off Core 2 fuel canisters loaded in each IFSF canister. Therefore, the total weight of a Core 2 IFSF canister should be $(38 \times 12)+295=751 \mathrm{~kg}$.

The locations of the Core 2 spent fuel canisters in IFSF are shown in Figure 39. Figure 39 also shows the canister with PTE-1 from Core 1. Plans are in place to move the Core 1 fuel that is in the FECF in CPP-603 at INTEC to the IFSF in the canister shown in Figures 40 and 41. Some of the fuel coming from GA \& ORNL will also go into the canister shown in Figures 40 and 41. 


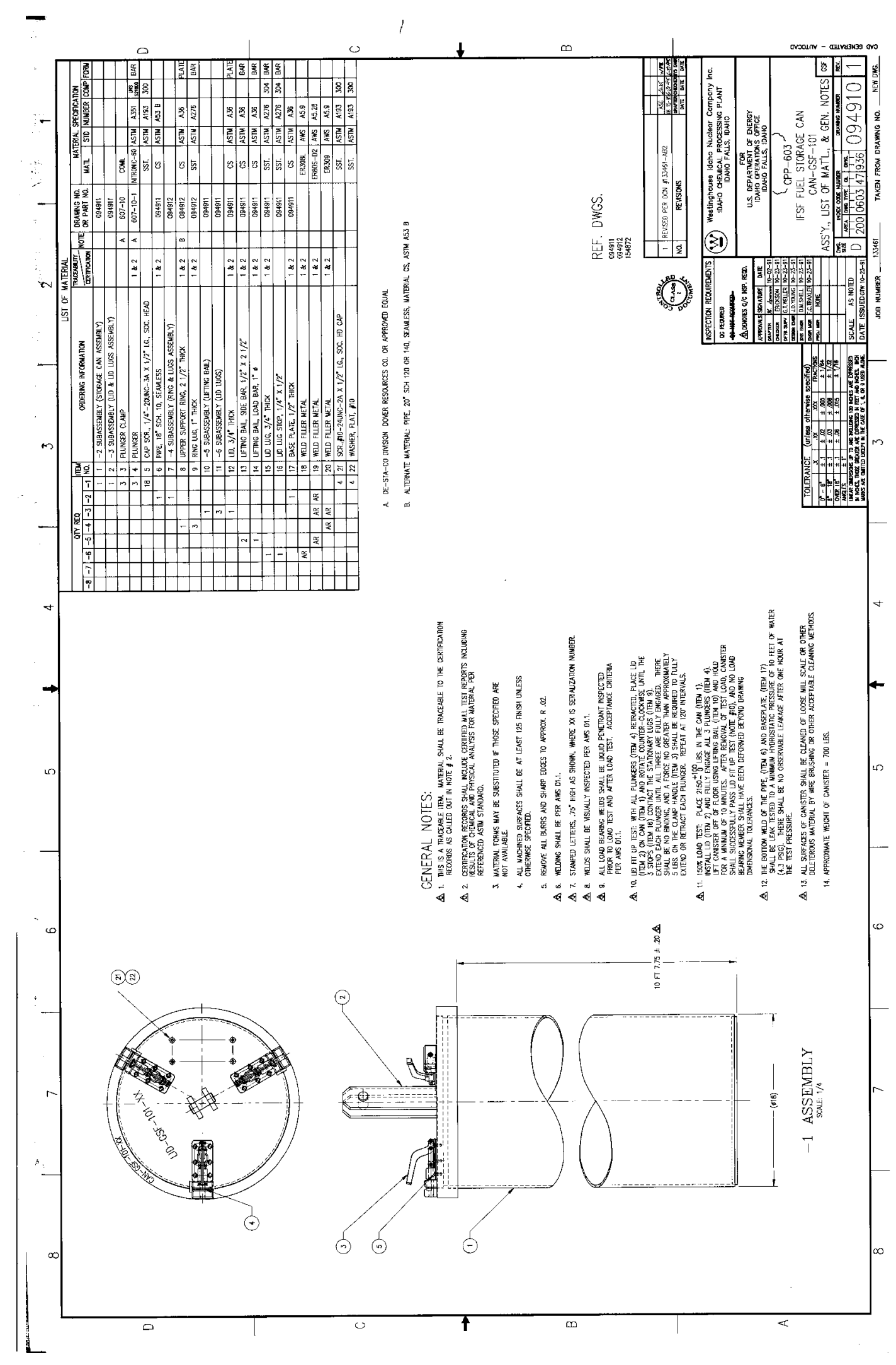

Figure 38. Illustration of Core 2 storage canister in the IFSF. Drawing 094910. 


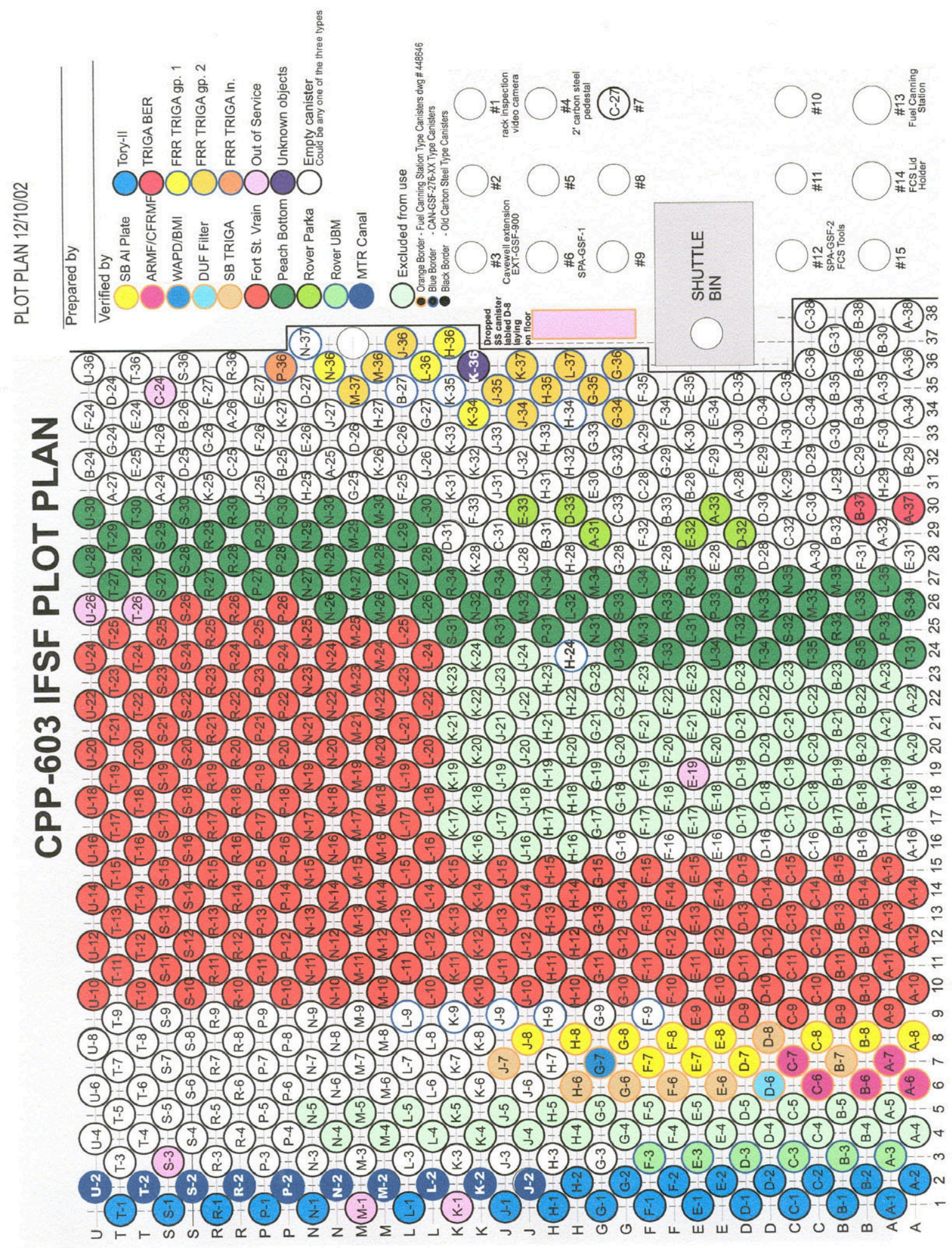

Figure 39. IFSF plot plan as of December 12, 2002. This plot plan is an information only copy. The official copy is updated and maintained by SNF Facilities Support at INTEC. 


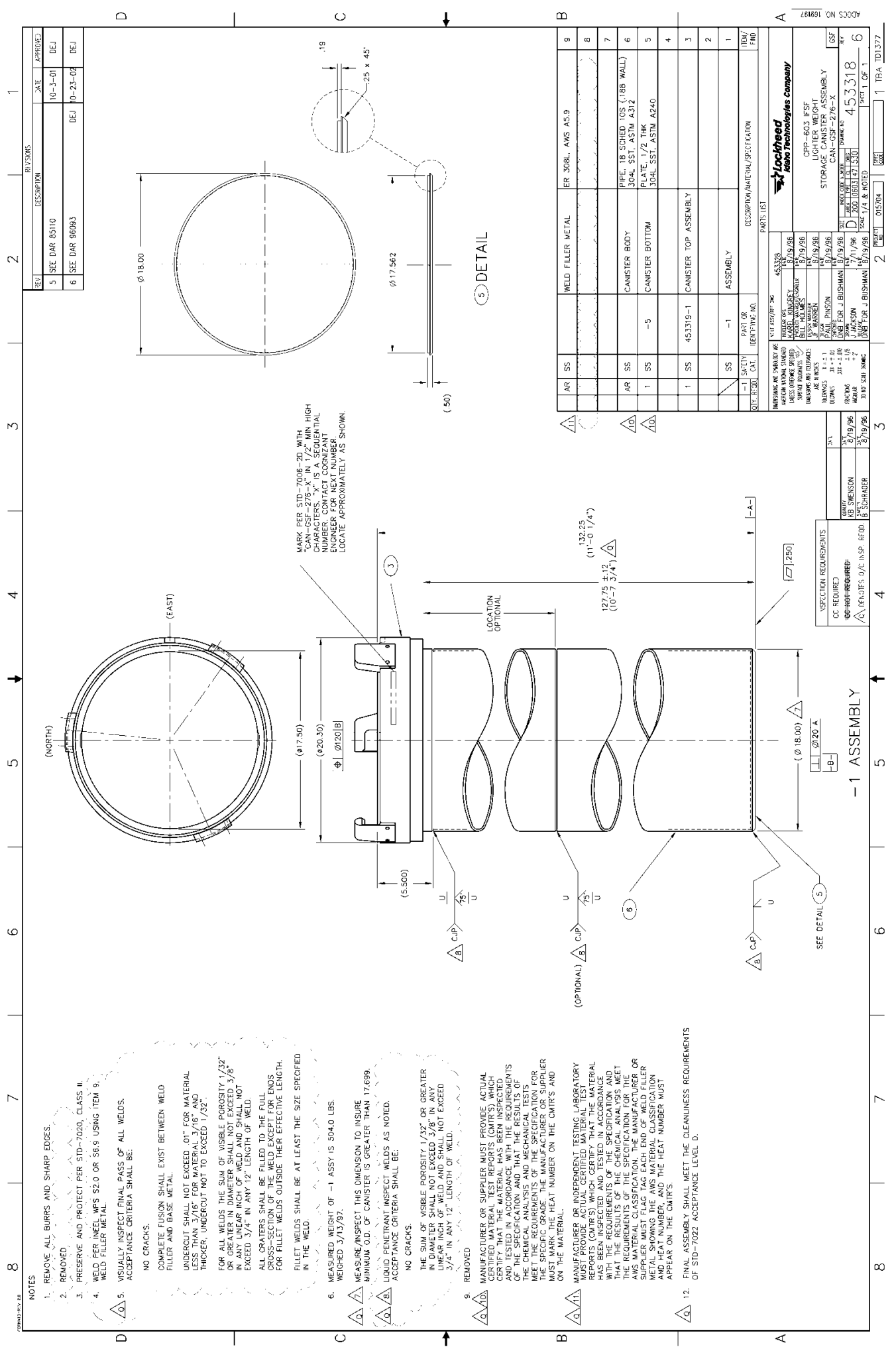

Figure 40. Canister planned for Peach Bottom Fuel currently in the FECF, CAN-GSF-276-X, Drawing 453318. 


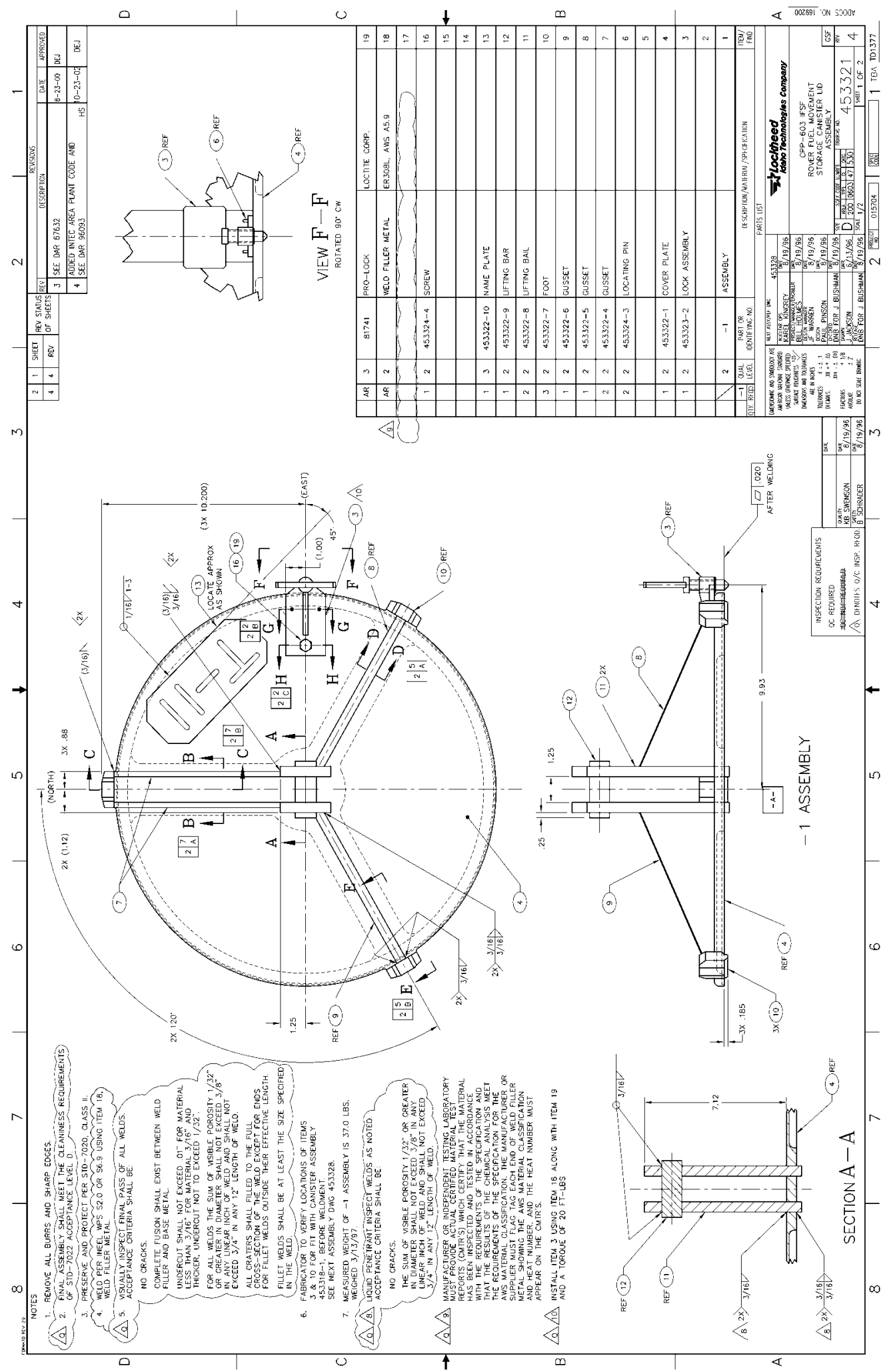

Figure 41. Lid to canister planned for Peach Bottom Fuel currently in the FECF, Drawing 453321. 


\section{DISCUSSION OF CORE 2 TABLE OF SPENT FUEL ELEMENTS}

Appendix B is a copy of an Excel spreadsheet for all Core 2 fuel, sorted by several different systems. Please see the discussion of Appendix A under Core 1 Fuel Storage for a description of the appendix tables.

Some source documents gave package types for the Core 2 fuel. However, because the canisters were removed from the Core 2 fuel elements before they were stored in the IFSF, the package type descriptions no longer apply. Package type was included in the Core 2 table when it was useful in identifying a specific element by its history.

It was not possible to precisely identify which elements were in which core locations at which times for all the elements. As much information as was located is in the Notes column of the table for elements that had incomplete information. Where no other information is shown, it is assumed that the burnup for the element was 897 EFPD. 


\section{ADDITIONAL INFORMATION}

There are a number of documents not cited previously in this report that can provide additional information, clarify information found elsewhere, or simply provide additional sources for the same information that is already discussed here.

These include:

- $\quad$ SOP 4.5.8, "Receipt, Storage and Retrieval of Peach Bottom Fuel at CPP-749," Idaho Chemical Co., 9-15-72. PB-0159.

- $\quad$ F. R. Romano, Pennsylvania Air \& Water Pollution Patrol, to Dr. F. Kruesi, United States Atomic Energy Commission, "Material-Waste (Radioactive) Stored/Shipped from Peach Bottom," March 20, 1973. PB-0069. This document includes the 4 pages of PB-0012.

- $\quad$ R. J. Burian, Battelle Memorial Institute, to Rom Lipenski, USAEC, Docket 70-1234, September 25, 1970. PB Cask-SAR-0001E.

- $\quad$ G. L. Wessman, Gulf General Atomic, to R. H. Logue, Philadelphia Electric Company, "Peach Bottom Unit No. 1 Fuel Cans," March 26, 1970. Peach Bottom-FRC-0008B.

- $\quad$ SDD-103, “INTEC CPP-749 Underground Fuel Storage Devices,” INEEL, October 21, 2002.

- V. P. McDevitt, Philadelphia Electric Company, to Dr. P. A. Morris, USAEC, Docket No. 50-171, "Request for Authorization of Facility Change and Associated Technical Specification Change (No. 14)," April 23, 1970. PB-0005 and FSV-0489 (256 pages).

- $\quad$ R. P. Wichner et al., Distribution of Fission Products in Peach Bottom HTGR Fuel Element E11-07, ORNL-5214, Oak Ridge National Laboratory, April 1977. PB-0032.

- $\quad$ General Atomics, HTGR/RERTR Fuel Materials Characterization and Packaging Report, PC-000384/2, April 2002.

- V. P. McDevitt, Philadelphia Electric Company, to Dr. P. A. Morris, USAEC, "Amendment No. 16 to Application for a Construction Permit and Class 104 License," January 28, 1970. PB-0003 and FSV-0487.

- $\quad$ R. P. Liversidge, Philadelphia Electric Company, to Dr. Pa. A. Morris, USAEC, "Request for Modification of a Core 2 Element at Core Location B16-10,” May 5, 1970. PB-0006.

- $\quad$ P. A. Morris, USAEC, to V. P. McDevitt, Philadelphia Electric Company, "License No. Dpr-12 Proposed Change No. 12," May 28, 1970. PB-0007.

- $\quad$ E. G. Bauer, Jr., Philadelphia Electric Company, to Dr. P. A. Morris, USAEC, Docket No. 50-171, "Request for Change In Technical Specification (No. 14) regarding Fuel Pin Test element program," March 23, 1971. PB-0008.

- $\quad$ G. L. Olson et al., Fuel Summary Report: Shippingport Light Water Breeder Reactor, INEEL/EXT-98-00799, Rev. 2, September 2002. 
- $\quad$ E. G. Bauer, Philadelphia Electric Company, to Dr. P. A. Morris, USAEC, Docket 50-171, "Request for Change in Technical Specification (No. 15), Regarding control rod and guide sleeve post-irradiation examination (PIE)," March 23, 1971. PB-0009.

- $\quad$ Philadelphia Electric Company, Request for Construction Permit and Class 104 License, April 10, 1972. PB-0010. Multiple requests for changes are addressed in five letters.

- $\quad$ EDF-2874, "Peach Bottom Core 2 Shipping Configuration for Transfer from CPP-603 Irradiated Fuel Storage Facility (IFSF) to Spent Nuclear Fuel Dry Storage Project, (Ref. Dwg. 518306)," Rev. 2, J. S. Layman, June 20, 2002.

- J. D. Hammond, R. S. P'Pool, and R. D. Modrow, , Safety Analysis Report for Peach Bottom 1 Core 1 Fuel Storage Facility, IN-1465, Idaho Nuclear Corporation, June 1971. PB-0098 and CPP-749-CSE-0001.

- $\quad$ EDF-2762, "SNF Data for Radionuclide Source Term Development for Five INEEL Fuel Types," Rev. 1, J. P. Henscheid and D. Fillmore, February 26, 2003.

- J. A. Lestyk, General Atomic Company, to R. E. Simonds, U. S. Atomic Energy Commission, Idaho Operations Office, "Appendix A, Contract AT(10-1)-1369," December 20, 1974. Peach Bottom-FRC-0013. This has package types for Core 2 fuel before the fuel was repackaged and proposed package types for some elements before they were shipped.

- J. A. Lestyk, General Atomic Company, to R. E. Simonds, Energy Research \& Development Administration, “Appendix A, Contract AT(10-1)-1369," February 6, 1975.

Peach Bottom-FRC-0013B.

- $\quad$ K. K. Kennedy, U.S. Energy Research and Development Administration, to J. A. Buckham, Allied Chemical Corporation, “Appendix A, Contract AT(10-1)-1369 (Peach Bottom)," February 11, 1975. Peach Bottom-FRC-0013C.

- $\quad$ Specification No. 3610, "For Spent Fuel Cans and Caps, Peach Bottom Power Station, Unit \#1," Philadelphia Electric Company, November 12, 1969. Peach Bottom-FRC-0005A.

- $\quad$ Memos from R. J. Conti, Philadelphia Electric Company to Allied Chemical Company, re: Shipping Load Charts, with attached loading order charts and loading tables are maintained by SNF Facilities Support. Only hard copies available for Core 1. The Core 2 record is PB-0164.

- DOE Forms 741 maintained by the INEEL Safeguards and Security group. These are by shipment number, not by element.

- V. P. McDevitt, Philadelphia Electric Company, to P. A Morris, Division of Reactor Licensing, USAEC, Docket No. 50-171, "Request for Change in Technical Specifications (No. 9)," November 17, 1969. PB-0002.

- $\quad$ Battelle Memorial Institute, Addendum No. 1 For Safety Analysis for the Shipment of Peach Bottom No. 1 Irradiated Fuel, Reference Docket No. 70-1234, "Elements in Whitehead and Kales Shipping Cask Model No. PB-1,” May 19, 1970. PB Cask-SAR-0001B. 
- $\quad$ Peach Bottom Unit No. 1 Spent Fuel Cans Materials Analysis, and other information that was attached to an attendance list from a meeting at ICPP to discuss Peach Bottom shipping canisters on December 12, 1969. Peach Bottom-FRC-0008A.

- J. A. Buckham, BUC-280-69, Idaho Nuclear Corporation interoffice correspondence to C. B. Amberson, "Integrity of Peach Bottom Fuel Containers," December 5, 1969. Peach Bottom-FRC-0008.

- $\quad$ M. E. Kantor, Recent Operating Experience at the Peach Bottom Atomic Power Station, GA-9047, Gulf General Atomic, November 10, 1968. PB-0027 and FSV-0101.

- $\quad$ Safety Considerations Related to Fuel Handling. Peach Bottom-CSE-0004. This appears to be a few pages from the Peach Bottom Reactor Final Hazards Analysis.

- V. L. Putman, INEEL, Criticality Safety Evaluation: FECF Peach Bottom Fuel Relocation, INEEL/INT-2001-00318, May 11, 2001.

- $\quad$ R. D. Theobald, Allied Chemical, interoffice correspondence to R. E. Commander, "Disposition of PTE-1 Peach Bottom Fuel Element," Theo-14-75, December 9, 1975. Peach Bottom-CSE-0006.

- $\quad$ EDF-1702, "Description of Peach Bottom Core 2 Spent Nuclear Fuel Unloading, Cutting and Placement Into IFSF Storage,” J. L. Hopla, February 15, 2001.

- $\quad$ M. J. Haire, Evaluation of Strontium-90 Radial Concentration Profiles in Peach Bottom HTGR Core 2 Fuel Elements, ORNL/TM-6209, Oak Ridge National Laboratory, February 1979. PB-0094. 


\section{REFERENCES}

1. W. A. Simon, General Atomics (GA) Company, to Larry J. Ferrell, INEEL, "Information Request for Peach Bottom Fuel Elements" GA/LANL-154-2001, CCN 19469 and 21763, April 27, 2001.

2. W. J. Scheffel et al., Operating History Report for the Peach Bottom HTGR, "Volume 1, Reactor Operating History," GA-A13907, General Atomic Co., August 31, 1976. PB-0018.

3. K. P. Steward, Final Summary Report on the Peach Bottom End-of-Life Program, GA-A14404, General Atomic Co., July, 1978. PB-0037.

4. $\quad$ R. P. Morissette et al., Characterization of Peach Bottom Unit 1 Fuel, GA-C18525, October 1986. PB-0066. Note: GA-C18525 is stamped with a disclaimer regarding the accuracy of the report, and with a notice stating the report contains information of a preliminary nature for internal use. The information in the GA report closely aligns with the type of information this fuel summary is intended to provide, so it is heavily referenced in this report. Where errors have been identified in the GA report, they are discussed in this fuel summary. However, much of the information in the GA report was presented without identifying how it was derived. It was not possible to confirm the accuracy of many of the tables and of the data in the GA report. As with other information in this fuel summary, material drawn from GA-C18525 should be considered unqualified.

5. A. Schwartz et al., Postirradiation Examination of Peach Bottom Fuel Elements E05-05 and C05-05 and Related Analyses, GAMD-8743, Gulf General Atomic, March 17, 1969. Peach Bottom-FRC-0005. This is an informal AEC Research and Development Report. It does not represent a final report.

6. J. L. Allen, Philadelphia Electric Company, to K. K. Kennedy, Idaho Chemical Processing Plant, "Peach Bottom Unit No 1 Spent Fuel Shipping and Reprocessing (Description of Peach Bottom Fuel extracted from the SAR) to the USAEC," February 21, 1969. Peach Bottom-FRC-0004 (22 pages).

7. J. A. Buckham, Idaho Nuclear Corporation, interoffice correspondence to F. H. Tingey and K. L. Rohde, "Peach Bottom Fuel Receipt," Buc-197-68, November 5, 1968.

Peach Bottom-CSE 0002.

8. F. F. Dyer et al., Postirradiation Examination of Peach Bottom HTGR Driver Fuel Element E06-01, ORNL-5126, Union Carbide Corporation, April 1976. PB-0050.

9. Philadelphia Electric Company, Application for Construction Permit and Class 104 License, Final Hazards Summary Report, Peach Bottom Atomic Power Station, PART C-II, February 1964.

PB-0001 (341 pages) also FSV-0487 (193 pages). The two records are not identical and neither of these records are complete copies of the Final Hazards Summary.

10. W. J. Scheffel et al., Peach Bottom 150 Full-Power Day Core Examinations, GAMD-8703, Gulf

General Atomic, Informal AEC Research and Development Report, December 31, 1968. PB-0043

11. W. V. Goeddel et al., Procedures for the Preparation of Graphite Matrix Fuel Compacts Containing Carbon Coated (Th,U) $C_{2}$ Fuel Particles, GAMD-2221, General Dynamics Corporation, General Atomic Division, AEC Research and Development Report, August 15, 1962. FSV-0252. 
12. R. D. Burnette et al., The Hydrolysis of Uranium and Thorium Carbides, GAMD-9670, Gulf General Atomic, Informal AEC Research and Development Report, October 1, 1969. PB-0174.

13. Gulf General Atomic, 40-MW(E) Prototype High-Temperature Gas-Cooled Reactor Postconstruction Research and Development Program, GA-9360, May 25, 1969. FSV-0245. This is a quarterly progress report for period ending April 30, 1969 and is an AEC Research and Development Report.

14. J. R. Hooker et al., Fort St. Vrain Proof Test Element Number One, GAMD-8552, Gulf General Atomic, Informal AEC Research and Development Report, June 12, 1968. FSV-0259.

15. R. E. Wilson, Allied Chemical, interoffice correspondence to R. E. Commander, "PTE-1 Peach Bottom Fuel Element Storage CSE," REW-5-75, December 19, 1975. Peach Bottom-CSE-0008.

16. J. J. Saurwein et al., Final Report on the Peach Bottom Test Element Program, GA-A15999, November 1982. PB-0021 and FSV-0029.

17. R. K. McCardell, Data Package for Peach Bottom High-Temperature Gas-Cooled Reactor Cores 1 and 2, INEEL/EXT-2000-00389, May 2000. PB-0173. This is an unqualified document and should not be used as a reference for design information.

18. R. F. Turner et al., HTGR Fuel Performance in the Peach Bottom Reactor, Gulf-GA-A12675, Gulf General Atomic, July 9, 1973. PB-0059.

19. Valerie L. Putman, Criticality Safety Evaluation: Peach Bottom Unit 1 Fuel in the Peach Bottom Casks and in the Underground Fuel Storage Facility, INEEL/EXT-02-00008, Rev. 1, August 2002.

20. P. A. Morris, United States Atomic Energy Commission, to V. P. McDevitt, Philadelphia Electric Company, Attachment A, "Change No. 9 to the Technical Specifications, Facility License No. DPR-12," Docket No. 50-171, February 19, 1970. PB-0004.

21. W. J. Scheffel et al., Operating History Report for the Peach Bottom HTGR, "Volume II, Test Element Operating History," GA-A13907, General Atomic Co., August 31, 1976. PB-0019.

22. EDF-3084, "Source Term Data for Shippingport LWBR, Peach Bottom, TRIGA, and Fermi Blanket SNF for Peach Bottom Cask SAR Revision,” Rev. 2, P. L. Winston, June 25, 2002.

23. F. J. Berger, to W. O. Price, Philadelphia Electric Company, Peach Bottom Atomic Power Station Unit No. 1, Instructions to Bidders and Specification for Nuclear Fuel Shipping Cask and Transportation, March 1969. PB Cask-COR-0000A.

24. C. W. Bills, USAEC, to Dr. J. A. Buckham, Idaho Nuclear Corporation, Master List of Fuel from Peach Bottom I, Appendix A, April 23,1971. Peach Bottom-FRC-0012A and Peach

Bottom-FRC-0010. An excerpt of this is in PB-0141.

25. EDF-2873, "Peach Bottom Core 1 Shipping Configuration for Transfer from CPP-749 to Spent Nuclear Fuel Dry Storage Project (Ref. Dwg. 518304)," Rev. 2, R. D. Denney, June 19, 2002. 
26. Battelle Memorial Institute, Safety Analysis for the Shipment of Peach Bottom No. 1 Irradiated Fuel Elements in Whitehead \& Kales Shipping Cask Model No. PB-1, January 15, 1970.

PB Cask-SAR-0000.

27. EDF-3350, "Peach Bottom Core 1 Loaded Basket Weight Analysis Using Solid Modeling," Rev. 0, R. E. Spears, February 5, 2003.

28. EDF-3296, "Engineering Analysis for TD-DSW-902 Support Plate for 4340 Pound Loaded Peach Bottom Basket," Rev. 0, J. W. Deatherage, Dec. 11, 2002.

29. PSD-4.6E, "Fuel Element Cutting Facility (FECF) Transfer Operations," Rev. 0, INEEL, INTEC Safety Analysis, October 23, 2002.

30. R. J. Kirkham, Westinghouse Idaho Nuclear Co., interoffice correspondence to J. E. Sailer, "The Chemical Reactivity of ICPP Stored $\mathrm{ThC}_{2}-\mathrm{UC}_{2}$ Fuels," RJK-07-94, July 20, 1994. PB-0065.

31. PLN-10, "Fuel Storage Facilities Sample Plan,” INEEL, Rev. 5, E. K. Boyd, September 25, 2002.

32. P. A. Anderson and H. S. Meyer, "Dry Storage of Spent Nuclear Fuel, A preliminary Survey of Existing Technology and Experience," NUREG/CR-1223, Exxon Nuclear Idaho Company, Inc. CPP-749-CSE-0006 (31 pages - no date given).

33. Precision Rubber Products Engineering Bulletin Number 5041, New Radiation Resistant Compounds for use on Nuclear Systems, November 16, 1967. Peach Bottom-FRC-0000.

34. A. J. Conti, Philadelphia Electric Co., letter to J. Hammond, Allied Chemical Co., attachment, Heavy metal isotopic information for Core 1. PB-0070 and Peach Bottom-FRC-0012A (see Reference 24). This is sorted by cap number.

35. Heavy metal isotopic information for Core 2. Peach Bottom-FRC-0019. This is sorted by shipment number. Parts of document are illegible.

36. J. R. Brown and K. R. Van Howe, Peach Bottom - Initial Loading to Criticality, GAMD-7351, General Dynamics Corporation, General Atomic Division, Informal AEC Research and Development Report October 1, 1966. PB-0039 and FSV-0253.

37. F. H. Tingey, Aerojet Nuclear Company, letter from to Dr. C. Wayne Bills, AEC, "Peach Bottom No. 1, Core 1 Fuel," Ti-203-74, May 7, 1974.

38. J. L. Everett III and E. J. Kohler, Philadelphia Electric Company, Peach Bottom Unit No. 1: A High Performance Helium Cooled Nuclear Power Plant, Annals of Nuclear Energy, Vol. 5, Pergamon Press 1978, printed in Great Britain, 1978, pp. 321 to 335. PB-0113. 